
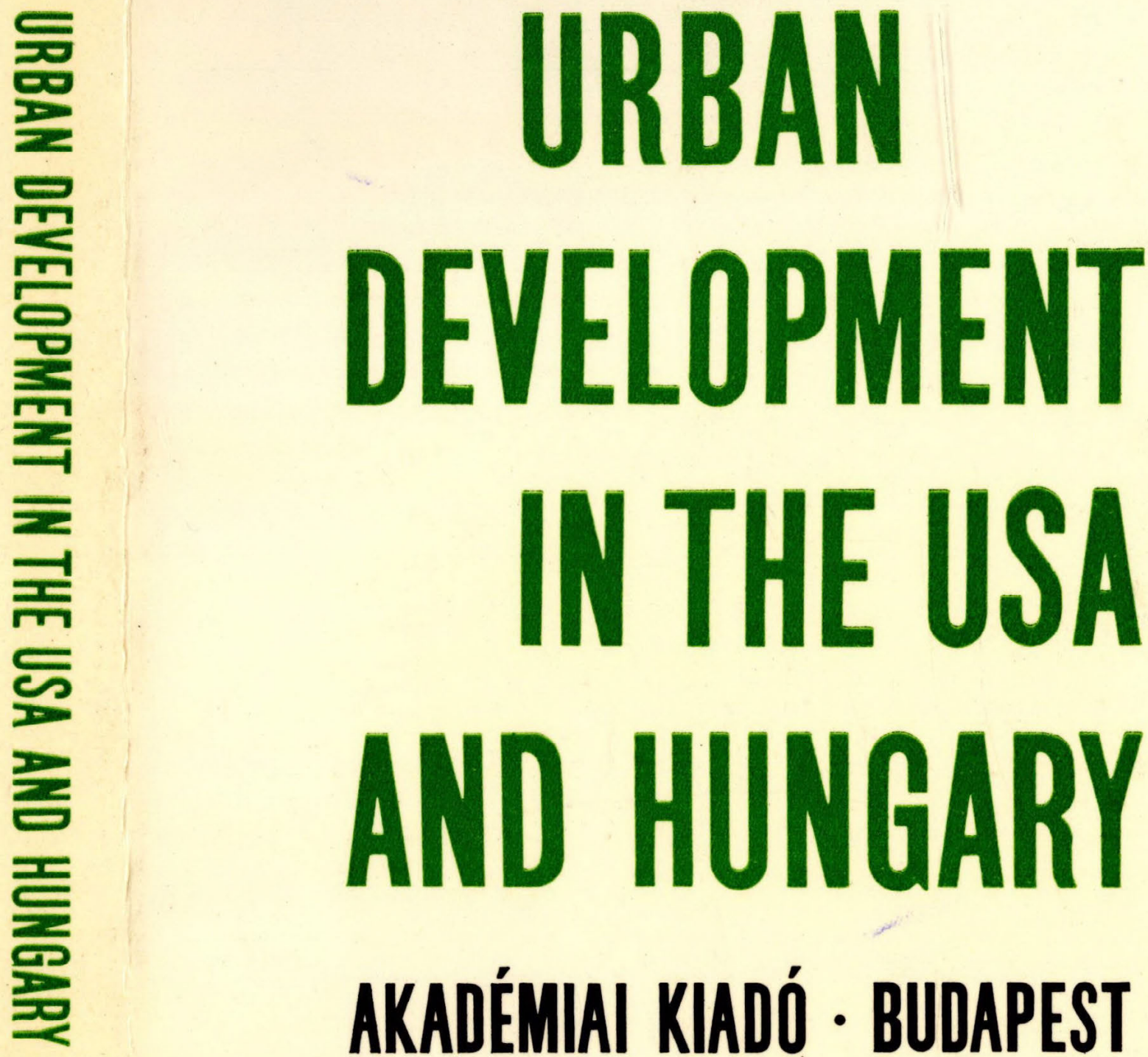

AKADÉMIAI KIADÓ • BUDAPEST

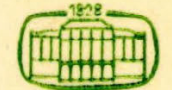




\title{
URBAN DEVELOPMENT \\ IN THE USA AND HUNGARY
}

\author{
EDITED BY
}

GY. ENYEDI

STUDIES IN GEOGRAPHY

IN HUNGARY, 14

This volume comprises the lectures delivered at the First American-Hungarian Seminar of geographers. The experts of the two countries dealt with the problems of urban development by grouping them in four major topics: 1 . Metropolitan growth as a nationwide phenomenon; 2. Internal urban structure and services; 3. The natural environment of cities;

4. The impact of urbanization on rural transformation.

The richly documented papers compare urban development in two countries of different size and social structure. Contrasting these highly dissimilar processes of urbanization, the authors have outlined the peculiarities of each. Information is also provided on a number of new research methods.

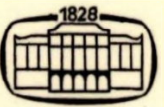

\section{AKADÉMIAI KIADO}

Publishing House of the Hungarian Academy of Sciences

BUDAPEST 
URBAN DEVELOPMENT IN THE USA

AND HUNGARY

1828-1978

PUBLISHED IN THE YEAR OF THE 150th JUBILEE 


\section{STUDIES IN GEOGRAPHY IN HUNGARY, 14}

\section{Research Institute of Geography}

Hungarian Academy of Sciences, Budapest

Chief editor:

M. Pécsi

Editorial board:

Á. Borai, Gy. Enyedi,

S. Marosi, J. Szilárd 


\section{URBAN DEVELOPMENT IN THE USA AND HUNGARY}

Edited by

GYÖRGY ENYEDI

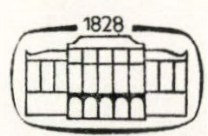

AKADÉMIAI KIADÓ - BUDAPEST 1978 
Translation revised by

PAUL A. COMPTON

The Queen's University of Belfast

ISBN 9630515148

(C) Akadémiai Kiadó, Budapest 1978

Printed in Hungary 


\section{CONTENTS}

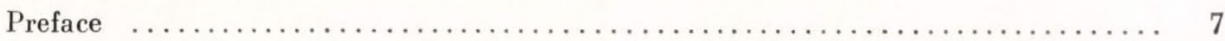

Preliminaries of the First American-Hungarian Geographical Seminar (J. MÉszÁros) . . $\quad 9$

\section{PART ONE}

\section{METROPOLITAN GROWTH}

VANCE, J. E., JR.: Metropolitan America - Evolution of an Ideal . . . . . . . . . . 15

Besuszky, P.: Changes in Urban Hierarchy with Specific Respect to Urbanizing Regions

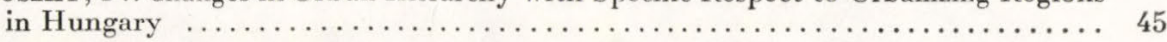

MorriLl, R. L.: Impacts of Urban Growth Centers on their Hinterlands . . . . . . . . 55

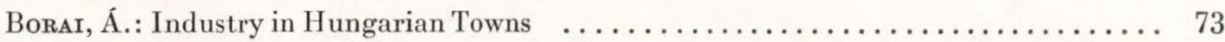

TATAI, Z.: Selective Industrialization and Dispersal of Factories from Budapest: their

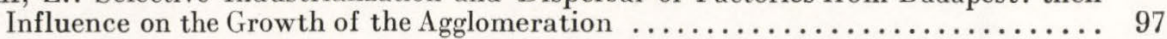

Deмко, G. J.: Population Redistribution and Migration Policy in the U.S. Urban Context 109

\section{PART TWO}

\section{URBAN STRUCTURE AND SERVICES}

Fonor, L.: Growth Model of the Agglomeration of Budapest ................. 131

Enyedi, Gy.: The Process of Suburban Development in Budapest . . . . . . . . . 137

PAPP A.: The Relationship between the City of Debrecen and Surrounding Settlements 147

Deskins, D. R., Jr.: An Index of City Structure Based on Empirical Observations … 155

Reynolds, D. R.: Metropolitan Governance and Service Delivery in the United States a Review and Synthesis of Research Findings ........................ 169

WheELER, J. O.: Research Directions in Urban Transportation Geography in the United

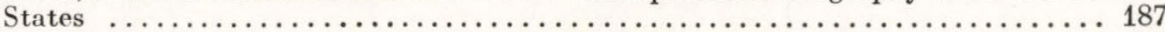

KIsH, G.: Central Business District or Shopping Center - an American Dilemma . . . . 205

\section{PART THREE}

\section{NATURAL ENVIRONMENT OF THE CITIES}

PÉcsi, M. and Katona, S.: Long-Term Development of the Budapest Agglomeration an Evaluation of the Physical-Geographical Potentials $\ldots \ldots \ldots \ldots \ldots \ldots \ldots \ldots 213$

Lowry, W. P.: North American Research Concerning the Effects of Urbanization on Local

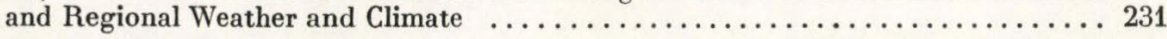

Prosánd, F.: The Problems of Air Quality in Budapest $\ldots \ldots \ldots \ldots \ldots \ldots \ldots \ldots .253$ 


\section{PART FOUR}

\section{RURAL TRANSFORMATION}

Haynes, K. E., Deare, D. and Harner, D.: Nonmetropolitan Change in Urban America - Texas, a United States Case Study

SÁrfalvi, B.: An Evaluation of the Functional Development of Rural Settlements

Using Educational Attainment as an Index of Methodology . .............. 287

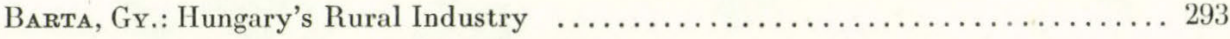

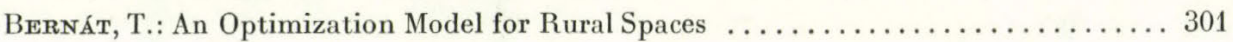

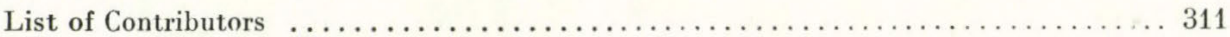




\section{PREFACE}

The problems of US and Hungarian urban development are highly different. Some similarity may be observed merely in technical details. Understandably there are differences in research concepts as well as in methods. Furthermore the small number of Hungarian research workers in the field of urban geography, compared to the great number of US colleagues adds to the differences. Hungarian geographers have to concentrate on several fundamental questions, such as how they consider the investigation of urban network development as well as the relationship between industrialization and urban development.

In the USA there are, however, a great number of geographers studying urban development, especially issues concerning urban structure and spheres of urban influence.

But a comparison of urban development in these two very different countries was very interesting. The differences may be derived from innumerable sources, the main features of urban development in capitalist and socialist countries obviously being different. Let us only refer to real estate values as a factor playing a tremendous role in capitalist urban development are ineffective in the socialist countries. On the other hand, carefully coordinated urban networks and central redistribution of urban budgets constituting foundations for socialist urban development, have no weight in capitalist countries.

US towns reflect a particular type even within the framework of capitalist urban development. The origin of their peculiarities is to be found in US history and in the typical features of American capitalism as well.

From the historical antecedents the most important facts emerges that the territory of today's United States, having become successively inhabited by a population of European origin, has been automatically highly urbanized. The first generation of US towns did not develop continuously as centers serving surrounding villages, but as seaports: as foci of overseas and national economic relations. Within the country the industrial towns expanded territorially, in highly concentrated conglomerations in the second half of the 19 th century at a tremendous pace. The most important US farming zone, that is the basin of the Mississippi River, had been inhabited only a little more than a century before. As a result of the conditions of its populating process, scattered rural settlement has become dominant. To supply the population of these scattered settlements, small towns with only a few thousand inhabitants have arisen at nodal transport points.

In the huge territory of the country all types of municipal hierarchy have been developed. The tertiary sector seems to be the major function in the majority of the large towns. 
Hungarian urban development is, of course, much older. Particular features of Hungary's settlement network were already developed in the Middle Ages. Capitalist urban development was, however, late and regionally uneven. Budapest's growth at the end of the 19th century showed an "American" tempo, but at the same time the market-towns in the Great Hungarian Plain were hardly being urbanized; most of their inhabitants were engaged in agriculture. A fast and nationwide process of urbanization involving the whole of the urban network has only begun since World War II, in connection with the industrialization of the country.

A particular feature of the Hungarian urban network is the capital city's outstanding significance. Budapest is the only Hungarian city, its influence is spread in the whole country. The five regional centers of the country are large country towns with a population of only one to two hundred thousand each. In some areas of the country, for instance in north-west Hungary, the network of small and medium-sized towns is also defective.

Hungarian urban development has been linked considerably to the transformation of rural areas. Most of Hungarian rural settlements are nucleated and the average number of inhabitants is quite high, attracting some simple, formerly urban services to them. Socialist large-scale collective farming has been drawing a lot of industrial, commercial and servicing functions into the villages. This is why analyses of Hungarian urban development and rural transformation are interdependent. This feature was manifested in the lectures as well.

Internal urban structures in the two countries as well as the character of suburban development are also very different. Residential areas in Hungarian urban centers have been in general of great value; in the distribution of the population within the towns no social segregation trends have asserted themselves, although the proportions of certain social strata in various quarters differ. Development of suburbs, apart from its much more modest size, has been another mechanism indicating the successive transformation of neartown rural settlements. Hungarian towns have preserved their urban communal manners of living better than the US ones, which had been disintegrated into their elements. Although possessing of a great number of renowned urbanists, the US has practically no comprehensive urban planning.

The problems of US urban structure have generated new methods of research work, which can cite the rather neglected Hungarian research into urban structures as well.

I hope the twenty papers of this volume not only facilitate comparison of the different urban development of the two countries, but also offer useful methodical and conceptional experience for all urban researchers.

I express my gratitude to J. MÉszÁnos, research worker of the Research Institute of Geography of the Hungarian Academy of Sciences for her help with the special compilation. 


\section{PRELIMINARIES OF THE FIRST AMERICAN-HUNGARIAN GEOGRAPHICAL SEMINAR}

The first formal meeting between the geographers of the socialist countries and the USA took place in August, 1972 in Montreal, Canada. On this occasion J. WARREN Nystron, executive manager of the Association of American Geographers suggested the organization of common research-work and also proposed seminars with the participation of socialist countries and the USA. This cooperation was based on a cultural agreement between the National Science Foundation and the socialist countries signed in 1972.

After two years of preparatory talks the Institute of Cultural Relations and the American National Science Foundation signed an agreement on the realization of the bilateral research project. The aim of this was to exchange ideas concerning urban development and jointly investigate the problems of urban geography. A form of the realization of the project was the exchange of views in seminars, the first of which was held in Budapest between 26 May and 5 June in 1975.

In choosing the topic of the seminar the following facts were taken into consideration: as a consequence of different social and economic conditions the process of urbanization was totally different in USA and Europe. Among others the difference can be seen from the rapidity of urban development. As a result of this, the so-called conurbations (agglomerations, metropolitan areas etc.) have been central topics for research in urban geography in the USA for a long time. As the evolution and development of conurbations can be recognized in Hungary also, the possible utilization of the American conclusions would be of great importance. This kind of exchange of ideas would also be profitable for American geographers in order to give detailed information about rural settlements and territories, as these are rare in the USA.

On the 26th of May all the participants of the seminar met in the councilroom of the Research Institute of Geography of the Hungarian Academy of Sciences (Budapest). After Gy. Enyedi's introductory remarks M. PÉcsi, the Director of the Institute opened the session. The opening speech informed the delegates about the research-work of the institute and its aims in the future.

The nine American delegates, under the leadership of G. KisH (University of Michigan, Ann Arbor), the thirteen Hungarian delegates with M. PÉcsI as Head of the delegation and the thirty invited guests expressed great interest in the lectures, held by J. E. VANCE (Metropolitan America - Evolution of an Ideal), R. L. MoRRILI (Impacts of Urban Growth Centers on their Hinterland) and Á. BoRaI (Industry in Hungarian Towns).

The second session included the following lectures: M. PÉCSI-S. Katona: Long-Term Development of the Budapest Agglomeration - an Evaluation 
of the Physical-Geographical Potentials; W. P. Lowny: North American Research Concerning the Effects of Urbanization on Local and Regional Weather and Climate; F. ProвÁLd: The Problems of Air Quality in Budapest; K. E. Haynes et al.: Nonmetropolitan Change in Urban America - Texas, a United State Case Study; Z. TATaI: Selective Industrialization and Dispersal of Factories from Budapest: their Influence on the Growth of the Agglomeration. The exhausting but very useful first day of the seminar ended with a reception given by the Hungarian Academy of Sciences.

During the third session next morning, G. KISH (Central Business District or Shopping Center — an American Dilemma), L. Fodor (Growth Model of the Agglomeration of Budapest), D. R. Deskrns (An Index of City Structure Based on Empirical Observations), G. J. Deмko (Population Redistribution and Migration Policy in the U. S. Urban Context) held lectures, each of which raised lively discussion.

The papers of the fourth session were on miscellaneous topics: Changes in Urban Hierarchy with Specific Respect to Urbanizing Regions in Hungary (P. Beluszky), Research Directions in Urban Transportation Geography in the United States (J. O. WHEELER), The Relationship between the City of Debrecen and Surrounding Settlements (A. PAPP), Metropolitan Governance and Service Delivery in the United States - a Review and Synthesis of Research Findings (D. R. ReynoLDs).

The delegates spent the following day surveying the agglomeration of Budapest. This programme began with a historical-geographical review, which was held on the top of the centrally-located Gellért Hill, from which the structure of the city could be seen well. Then the geographers drove through the capital, touching upon the vital parts of the agglomeration (e.g. a new housing estate, industrial, residential and recreational areas).

\section{STUDY TRIP}

A conference in geography cannot pass without visiting the countryside; having a look at the phenomena in the field as it offers as much knowledge as the lectures. That is why the session of lectures had been followed by a study trip in case of the First Hungarian-American Seminar, too. Time was short, but the Hungarian organizers of the seminar tried to show as much of the country as possible.

The first day was spent by visiting the reconstruction of the city-center in Salgótarján (an old mining town) and by having a look at an ancient city, where the historical city-core had been preserved (Eger). The following day was devoted to a tour around the Great Hungarian Plain. As this region plays an important role in the economic life of Hungary it was important to inform the American delegates about it in detail. The Hungarian experts spoke first about its geographical formation, its physical geography and landscape as a basis for economic utilization. In connection with this emphasis was laid on flood control. After visiting one of its most important towns (Debrecen) the participants were driven through the areas of scattered farmsteads (so-called "tanya") and could hear about the political-economic reasons of their formation and about their economic role. 
The fifth session of the seminar had been held in Kecskemét, a former rural market town, which was the center of scattered farmsteads. Accordingly, the lectures were as follows: Gy. BARTA: Hungary's Rural Industry; T. BERnÁt: An Optimization Model for Rural Spaces; Gr. Enyedi: The Process of Suburban Development in Budapest; B. SÁRFALVI: An Evaluation of the Functional Development of Rural Settlements Using Educational Attainment as an Index of Methodology.

This valuable programme was followed by visiting some towns in Transdanubia. Crossing the Danube, the first stop was at the new industrial town, Dunaújváros, after which the delegates obtained an impression of the beautiful Balaton resort area. On the way back to Budapest the role of small towns in Hungary's settlement structure was discussed.

\section{CLOSING SESSION}

On the 4th June the American and Hungarian delegates assembled again in the council-room of the Research Institute of Geography for the closing session. A resolution was put forward on the importance and usefulness of collective research in urban geography. So that the delegates from both sides agreed in meeting in the USA next. They also expressed their gratitude to the National Science Foundation, the Institut of Cultural Relations and the Geographical Research Institute for their collaboration.

Júlia Mészáros 

Part one METROPOLITAN GROWTH 


\section{METROPOLITAN AMERICA - EVOLUTION OF AN IDEAL}

By

JAMES E. VANCE, JR.

The role of the city in American life has been ambiguous throughout most of the three hundred and fifty years of European settlement in what is now the United States. The American Revolution just two centuries ago, which freed us from overseas domination, did not furnish any widely accepted plan for city founding and city filling in the new nation. For most of that two hundred year period there has been no clearly perceived design for urbanization, and it seems fair to say that even today the separate points of view on the question are sufficiently numerous to make any statement of a "national policy" or a "national plan" on the matter impossible. Although this is a critical concern in a society where most people live in cities and large parts of the social and economic problems facing the United States come from conditions within cities, only once in recent political history has the matter of the geographical form and location of cities been raised in election debate. That was in 1968, when Hubert Humphrey and Richard Nixon were contesting the presidential election, a campaign in which then Vice President Humphrey proposed solving the problems of urban America through the creation of "New Towns". These were to be physically separate towns of moderate size - perhaps 100,000 200,000 population - set out in previously open country and intended both to stop the further physical expansion of existing cities and to furnish what Humphrey viewed as a better urban environment than currently available. In a sense the Vice President's proposal was strongly influenced by two fundamental ideas that have been characteristic of American urbanism since the English settlers arrived in the early seventeenth century: the first was that there should not be an excessive concentration of political administration and economic activity in one or a few cities, and the second was that full development of geographical regions required the planting and sustaining of locally based cities.

The first of those urban ideas was a reaction to absolutist monarchy and monopolistic mercantile theory that held sway in England at the time of the American colonization, a matched pair of concepts that led to distant and autocratic government and economic subservience for the American population. They were expected to serve in a restricted fashion as the simple rural produces of staple raw materials for which they would be paid in English manufactures and for which there might be no competing American industry. In such a context there should be no surprise that for the American settlers the city became a symbol of independence, from the feudalism of the Middle Ages with its geographical fixity in rural serfdom, for the laboring classes, and from the domination by a distant colonial power. Thus, the Puritan 
merchants who migrated to Massachusetts in 1630 struck a true blow for liberty when they insisted that America must have the freedom to build cities and the ability to engage on equal terms in the economic life of the British Empire. Britain was indifferent to the first desire but actively hostile to the second. Because towns did develop in the New World a base for revolt came into existence, and in 1776 it was the native mercantile society of Boston that first took up arms against Britain and specifically in terms of the freedom to develop locally the economic base for a fully accomplished mat rial life. In a sense, those rebels at Lexington and Concord when they fired upon the British troops were doing so in hope of being able to use what we now call the "growth pole theory" for the accomplishment of economic justice. When the Revolution proved successful in 1783 the emergent nation quite logically sought to assure just such a regional justice in economic and urban development as had been denied by the English tyrant.

\section{THE ROLE OF URBAN LAND SPECULATION IN REGIONAL EQUALITY}

Here it is impossible to expand at any length on the original pattern of urban development in the United States beyond citing its fundamental qualities. The first cities to be established in the New World were those planted by a group of citymen from London, Bristol, Plymouth, and several other trading cities of England. These city merchants of England formed a class distinct from the rural oligarchy that dominated the government and they came increasingly into conflict with that agricultural aristocracy to the point that in the 1640 's they turned on the crown, defeated the king's armies, and subsequently beheaded him on a scaffold outside his own Banqueting Hall. But before those happy events occurred in England, many of the more freedomloving protestors migrated to New England in the period 1620-1645. They settled around Massachusetts Bay and there set up towns organized on extremely democratic, though unfortunately rather theocratic, lines. Their's was a "commonwealth" of towns wherein everyone lived in a "municipality" even if he tilled a field. Many New England planters engaged in clearly urban activities from the very beginning and it is a general truth that what agriculture did develop, came from the demands of the local towns for food and staples for shipment in their developing long-distance trade. In no sense was this a CHRISTALLER "central-place system" but rather a true expression of a mercantile organization of economic life. As such we can say that the first towns of America were planted, not emergent from the local agriculture as in Christaller's view of nineteenth-century Bavaria, and so the New England town was established by men who made that town the most democratic institution since Classical Greece.

While these activities were taking place in New England, with Boston growing within less than a century to rank alongside Bristol, Norwich, and York as one of the five largest English towns (London of course being vastly greater than any of these in size), in other parts of the American colonies other English models were being adopted. In the Middle Colonies - New York, 
New Jersey, Pennsylvania, Maryland, and Virginia - the society took a different course. These were so-called "proprietorial colonies" wherein the English king had granted to a small group of men, commonly from the nobility, a great area of unsettled land - that is settled only by Indians - in which they could establish what we would term a class-divided society. There were attempts to introduce certain feudal practices such as the laying out of manors, the collection of feudal dues (quitrents and tithes), and the creation of some conditions of labor servitude (indenture and enslavement). Particularly where these feudal practices were most developed, as in Maryland and Virginia, towns failed to develop. The colonial legislatures of both those provinces adopted special enactments calling for the creation of towns, as they had not emerged in the normal course of settlement, but the call was largely unrewarded. Instead the royal governors of Maryland and Virginia (actually the same man, Francis Nicholson, who moved from governorship of Maryland to that of Virginia) had to set up rather artificial "government towns" in Annapolis in Maryland and Williamsburg in Virginia so that they might have a fitting place from which to administer. These were administrative centers pure and simple which have never grown into real cities. They shared one quality with the earliest cities to be laid out in the South Atlantic colonies (South) Carolina and Georgia - that was the adoption of a rather aristocratic Renaissance design. Annapolis, Williamsburg, Charleston (South Carolina), and Savannah (Georgia) were the only Renaissance towns laid out in the United States. As such they were the product of a basically class-divided pattern of society which was emplanted by proprietorial companies composed largely of members of the English aristocracy. Out of those proprietorial efforts came mainly the creation of large landed estates, which in the American South were called "Plantations", where commercial crops were grown by slave labor. For certain periods of the year - particularly in the summer when the wet fields of the rice plantations were breeding grounds for disease - the planting aristocracy left for the towns there to live during a Social Season similar to that found in London or Vienna (and presumably Habsburg Budapest). In such a social and settlement context the countryside was virtually devoid of towns; only the one large town of a considerable region had any urban existence. For the average person city life was unknown, leaving its experience only to a minute planter aristocracy.

If the merchant's town in New England and the governor's and aristocrat's capital in the South were the first two models of settlement in American history, the next to follow was the model that caught hold, becoming so widely adopted in the development of the country as to seem the only one that ever existed. This was the town as it evolved in the first few years of the Pennsylvania settlement, that is between 1680 and around 1700. Fundamentally this was a town dedicated almost entirely to opening up undeveloped country, frequently for social and political purposes but always with the intention of gaining for the individuals initially involved in the undertaking a speculatively based capital gain. To a very high degree town founding in America was a form of collective private enterprise, open to many persons, and productive of truly large speculative profits. In many ways such town founding was the most democratic of business operations, in part because

2 Enyedi: Urban 17 
there were many participants in the developmental operation and in part because it produced a society without the narrow ownership of land (by the aristocracy) which proved so inimical to the interests of the common man where it was found in European monarchies.

Before going on, it is necessary to return for a moment to one of the other models first used for the urbanization of the New World in the United States. This was the mercantile model of town building that was adopted in colonial Boston. There there was no real speculation in land - land was assigned only at the time of actual use and in quantities commensurate with the individual's ability to use it - but there was the establishment of a practice equally as significant as that of land speculation. This was the determined adoption of the practice of freehold ownership of land, in the city nearly as much as in the countryside. America, following on New England practice, became a land, and ultimately a nation, firmly based on owner-occupancy of farms in the countryside and the widespread ownership of land in the city. Before the industrial revolution of the late eighteenth century it was the common practice in cities for families to occupy single houses which they owned, or which they rented from a landlord holding only one or two properties. The large urban "estate" of houses such as those in contemporary London, wherein an aristocratic landlord granted leaseholds on a large scale for development of housing by others, was missing in America. Whatever the failings of land speculation within cities, and they were considerable indeed, there was not the narrow profiting by the increase in the value of land found in Britain. Quite simply, in America if a city grew quickly and importantly many gained prosperity thereby, and all who held property, and that was a large group indeed, at least hedged against the speculative rise in property values.

There was a rather unappreciated outcome of this wide ownership of urban land which arose when industrialization quickly expanded urban populations in the early nineteenth century. Because so many urban holdings were small and possessed by skilled workmen or even well established factory employees, there was a great tendency for the rapidly expanding demand for urban housing to be met by the development of such properties. Without here going into detail, we should note that such petty landlordism often produced the worst slums because the holder of a single property often showed the desire to extract the highest possible return from single property, thereby crowding as many tenements on his one lot as could possibly be done, and because the petty landlord seldom had the capital to build wisely or well. But for now we should return to the role that speculation played in the actual founding of cities.

There were certain distinctive characteristics of the "speculator's town" which came to be associated with most American towns as they were founded. In Philadelphia WiLLIam PenN, the Quaker founder of the colony and of its chief town, established in 1681 what he termed a "holy experiment" but which became, in fact, a most profitable and business-like one. Penn ordered that his town be laid out in rectangular blocks with rather narrow lot frontages. Even more importantly he had a city one mile wide and two miles long laid out between the Delaware and Schuylkill rivers, providing a town site more than twice the size of London within its walls. In this act we find what was prob- 
ably the first instance of surveying and laying out a vast speculator's tract which was several generations ahead of its likely growth in size. Within that vast area of some 1,280 acres $(518.2 \mathrm{ha})$ there was the provision of building lots on such a scale that no immediate purpose could account for it, and we must only assume that creating the raw material for land speculation was the intent. Certainly the experience with Philadelphia bore out such an expectation: even in the Proprietor's time, there was much increase in land values and much gain in capital won by distant investors who remained in England. Philadelphia already at the end of the seventeenth century demonstrated that one of America's most abundant resources was to be found in the development of towns-abundant because there was such a vast country without any pre-established political geography and potentially rewarding because there were to be so many small landowners who were encouraged by the same hopes for individual speculative gains that land sales could be far greater in number than were the actual buildings placed on the land. In New England the notion of democratic landownership had been established: this was joined to the Pennsylvania practice of land speculation to form the basic process that planted cities from the Atlantic to the Pacific in the new land.

It was the absence of "established orders" that made this free and expansive market possible. In Europe the modern era followed upon a long period of traditional orders: of administrations begun by the Romans, of the church of Rome and its geographical administrative units, of the military organization of the Middle Ages which divided the realm into fiefdoms, and of the medieval economy which was enclosed into localized "natural economies" typical of feudalism. In Europe, within the period of developed economy, there never has been a tabula rasa for geographical experimentation. The inherited order became the dynamic of economic organization, a fact clearly borne out by the observation and analysis advanced by WALTER CHRISTALLER in 1933. When Christaller analyzed Bavaria he discerned a great "natural order" that he called central-place structure. His notion was that the gravitation of individuals from the countryside into cities for retail trade and personal service brought those cities into existence, as central places. The underlying assumptions were (1) that the countryside was already in existence as a home of man, (2) that the rural economy is a fundamental one, (3) that cities thus grow out of that countryside and the needs of its population, and (4) that growth in towns results from the growth in the population and economy of the countryside. Christaller and his followers have always been forced into this view of cities growing from the land in a non-industrial, and as well a largely local-trading, economy. Neither the role of the distant trader nor that of the industrial worker is easily comprehended under central-place theory. Instead there is more than a whiff of the Middle Ages in all of this. Specifically, the central-place model is one of "established order", with that establishment's coming from military-administrative demands.

We all know that feudalism was perhaps the most definite geographical system ever devised. The working class, through serfdom, was legally fixed in its residence; areas of administration were equivalent to areas of military domination; and the ordered social structure of feudalism (Heerschildordnung in South Germany) was militarily established but administratively continued. 
It is my contention ${ }^{\star}$ that central-place structure simply reproduced that Heerschildordnung with a pattern of administrative units which grew out of the military-to-feudal-to-administrative ordering of the European lands. The medieval economy, particularly in the Holy Roman Empire, was heavily rural, so its administration was similarly areal and rural. We should not forget that feudalism was not abolished in that Empire until Napoleon did the job in 1808. Thus, the time gap between the legal closing of medievalism and Christaller's observations drawn from the heart of the Empire (Bavaria) was less than a century. For that reason it seems just to argue that central-place theory was both in its geographical origins and in its concepts an outgrowth of a particular, and very far from universal, economic and social order wherein the structure was not inevitable but instead the result of certain administrative practices grounded in German feudalism.

When we turn back to America the failings of such a central-place system should be obvious. Firstly, when American lands were settled history tells us that it was particularly the desire to expand the mercantile economies of the North Sea lands (Holland, France and England) that accomplished that task. Certainly the first planting on the American shore came in towns: generally the oldest settlement in each of the colonies was a true town and has tended to become the largest city of a major region: Quebec (1608); New Amsterdam (New York) (1626); Boston (1636) and Philadelphia (1681). Thus, the countryside was savage when the towns were both civilized and growing. There was in the New World no existing political order that affected the Europeans so they had to devise one, and it emerged strikingly different in its form from that found in post-medieval Europe. The towns of America were dominated not by local trading interests and administration but by a powerful and growing long-distance trade. Finally, within little more than a century after its full settlement America followed quickly in the steps of Britain (and in harness with Belgium) to become the second nation to industrialize. As such an early industrial nation a model (such as that of Christaller) simply did not apply to American urbanization. Instead we must seek, in our pursuit of an understanding of American metropolitan development, some different explanatory device.

In America there was no pattern to follow so a considerably new one was shaped. Its rudiments have already been noted: the free, democratic, and hopeful ownership of land and the search to use incremental gain in land values as a national "natural resource". As a device for the efficient development of a national economy, particularly an integrated one, the planting of "speculator's towns" had faults. But as a device to accomplish a geographical "balance" within a national economy this was a powerfully effective as well as an original system.

* In The Merchant's World: The Geography of Wholesaling. Englewood Cliffs (N.J.): Prentice-IIall, Inc., 1970. 


\section{GEOGRAPHICAL SPREAD IN A SYSTEM OF SPECULATION IN TOWN FOUNDING}

The world has seen a number of different motivations for moving away from a traditional home and setting upon the road toward a frontier. To Hungarians just as to Americans such movements are part of a glorious history so I need not explain the existence of such long-distance and long-continued movement. Rather we may concentrate on the way the followers of the frontier created a new settlement on that frontier. In the earliest settlements on the Atlantic coast of America the settlements were placed to facilitate long-distance trade, with France or with England as the case may be; these were the colonial ports which became the great ports-cities of the United States when political independence opened a larger world to American merchants. For the most part, Philadelphia was the obvious exception, these ports began as small towns, timid in their expectations if we may judge from their initial layout of streets and houses. In the beginning the speculator's gamble was in the economic survival of such a mercantile implantation in the New World. Once that gamble had been won, the instinct that projected European economic life across the Atlantic was neither extinguished nor constrained to following that single source of development and economic growth that the planting of trading towns represented. The economically optimistic, who were thought by European visitors of the nineteenth century to be the typical Americans, could not wait for the development of trade with further advance of the frontier. Instead they wished quick realization of returns, such as those William Penn and his investors experienced through the sale of land, whose value rose more quickly than the production or trade figures for the Pennsylvania colony. As soon as roads could be hacked through the unbroken forest, towns were planned at any likely spot and earnest and often strident efforst were made to sell these potentially urban lots to persons moving with the frontier or to those who never left their homes. Each was urged on to such a purchase with the argument that a great city would grow at the Forks of the Ohio River (Pittsburgh), the Falls of the Ohio (Louisville) or the mouth of the Licking River where it fell into the Ohio (first Losantiville but eventually Cincinnati). The towns I mention survived and prospered, that is why I can use them without utterly confusing you. A greater number simply grew up again to trees and are by now forgotten even by those who invested in their lands.

The critical point I wish to make at this place is that there was a vast choice of speculator's "towns" on the frontier as it developed. There was no existing order there, no natural structure inherited from the past, and no administrative system to decree where civic functions would be located. Rather there was a true economic tabula rasa on which complex and current forces could create a pattern of metropolitan development. If any settlement situation might be expected to show innate and enduring forces at work in urban location and support, this spread into the interior of the United States was such a case. Clearly it did not produce the central-place pattern that theory would anticipate but instead a set of conditions of quite different form and origin. 
To portray the evolution of the American urban pattern it is useful to record what were the larger cities of the country at various periods of time. Taking the first Census of the United States in 1790 the following pattern emerged (Table I).

\section{TABLE I}

The ten largest towns in the United States in 1790

\begin{tabular}{c|l|c}
\hline Rank & \multicolumn{1}{|c}{ Town } & $\begin{array}{c}\text { Population } \\
\text { in } \\
\text { thousands }\end{array}$ \\
\hline 1. & New York, New York & \\
2. & Philadelphia, Pennsylvania & $33 \cdot 1$ \\
3. & Boston, Massachusetts & $28 \cdot 5$ \\
4. & Charleston, South Carolina & $18 \cdot 3$ \\
5. & Baltimore, Maryland & $16 \cdot 3$ \\
6. & Salem, Massachusetts & $13 \cdot 5$ \\
7. & Newport, Rhode Island & $7 \cdot 9$ \\
8. & Providence, Rhode Island & $6 \cdot 7$ \\
9. & Gloucester, Massachusetts & $6 \cdot 3$ \\
10. & Newburyport, Massachusetts & $5 \cdot 3$ \\
& & $4 \cdot 8$
\end{tabular}

Each of these ten was an important port, as were the next ten cities also ports of somewhat less stature. The first town beyond the reach of tidewater was Worcester, Massachusetts, with only two thousand people, which stood only 28 th in the ranking. Four of the first ten cities were ports on the short Massachusetts coast, as were seven of the first twenty. The obvious domination of American urbanization by points on the coast where trading ties with Western Europe, the Newfoundland fisheries, and the sugar islands of the West Indies were landed on the American shore is striking. This was no centralplace system but instead a dominantly mercantile one with the towns sited where long-distance trade would place them.

Forty years later, in 1830 , the Census revealed relatively little change (Table $I \dot{I})$.

\section{TABLE II}

The ten largest towns in the United States in 1830

\begin{tabular}{c|l|c}
\hline & \multicolumn{1}{c}{ Town } & $\begin{array}{c}\text { Population } \\
\text { in } \\
\text { thank }\end{array}$ \\
& & \multicolumn{1}{c}{ Nousands } \\
\hline & New York, New York & $202 \cdot 5$ \\
1. & Baltimore, Maryland & $80 \cdot 6$ \\
2. & Philadelphia, Pennsylvania & 80.4 \\
3. & Boston, Massachusetts & $61 \cdot 3$ \\
4. & New Orleans, Louisiana & $46 \cdot 0$ \\
5. & Charleston, South Carolina & $30 \cdot 2$ \\
6. & Cincinnati, Ohio & $24 \cdot 8$ \\
7. & Albany, New York & $24 \cdot 2$ \\
8. & Brooklyn, New York & $20 \cdot 5$ \\
9. & Washington, District of Columbia & $18 \cdot 8$ \\
10. & & \\
22 & &
\end{tabular}


Ports continued to dominate but now there were several on rivers - New Orleans, Cincinnati, and Albany - and there was the first governmental center to reach a dominating size, Washington, which had only been founded during the 1790's. As in the first census, the tenth to twentieth cities were also ports, six on the sea and four on rivers. The new element discernible in 1830 was the role being played by industry, which had begun initially in or closely adjacent to the major Atlantic ports. By 1830 the river towns of the Ohio Valley had furthered this association of port and factory when, after 1811, Pittsburgh became a great center for machine and metal industries as a result of for a few years being the greatest steamboating building city in the world. Cincinnati processed agricultural products whose production had been encouraged by the existence there of a mercantile mechanism for shipment to the East and industrializing Europe. Still in 1830 there were no sizable emergent central places in the United States. The cities of America were so strongly mercantile and tied to long-distance trade that there can be no question what was the city founding process at work.

What the census figures do not reveal is that town planting not only preceded the development of a productive countryside but also took place so frequently and in geographical dispersion that there was a vast set of "potential towns" available for development. The actual development came largely as a response to the shaping of a regional and national transportation system. To go back a moment: it was the great desire to create capital through land speculation that made the great array of "potential towns" available. Because there was no "law", either administrative or economic, to make certain where a town would grow, many possible towns could be planned. Which of those towns gained reality in more than the existence of a paper plan depended heavily on transportation technology, long-distance routes, and subsequently the flow of raw materials for industry. Thus, in 1790 and 1830 water transport dominated not merely the location of towns, but as well the location of initial industrialization.

For a decade or more after the building of the first factory in 1791 at Providence, Rhode Island, industry was heavily concentrated within twentyfive miles of that city. Even when other East Coast ports sired their own industrial establishments - at Paterson, New Jersey, and Lowell, Massachusetts, for example - these were tied closely to the original alignment of ports that created metropolitan America, then heavily concentrated in Jean Gottmann's "megalopolis". We may explain such a concentration of industry as heavily dependent upon raw materials brought over fair distances - as the cotton from the American South - and on the almost exclusive clustering of potential labor in the only cities that then existed, the ports. Only as agriculture declined in New England, in the 1830's and 40's, and in the South at the beginning of this century, was there much of a surplus of labor in the countryside. So, at least in the earlier decades of the industrial era, industrialization in America was in the "port towns" located on Atlantic harbors and landing places on the interior rivers.

In 1870 the important towns of America can no longer be limited to ten. Taking the first twenty, the following pattern emerges (Table III). 


\section{TABLE III}

The twenty largest towns in the United States in 1870

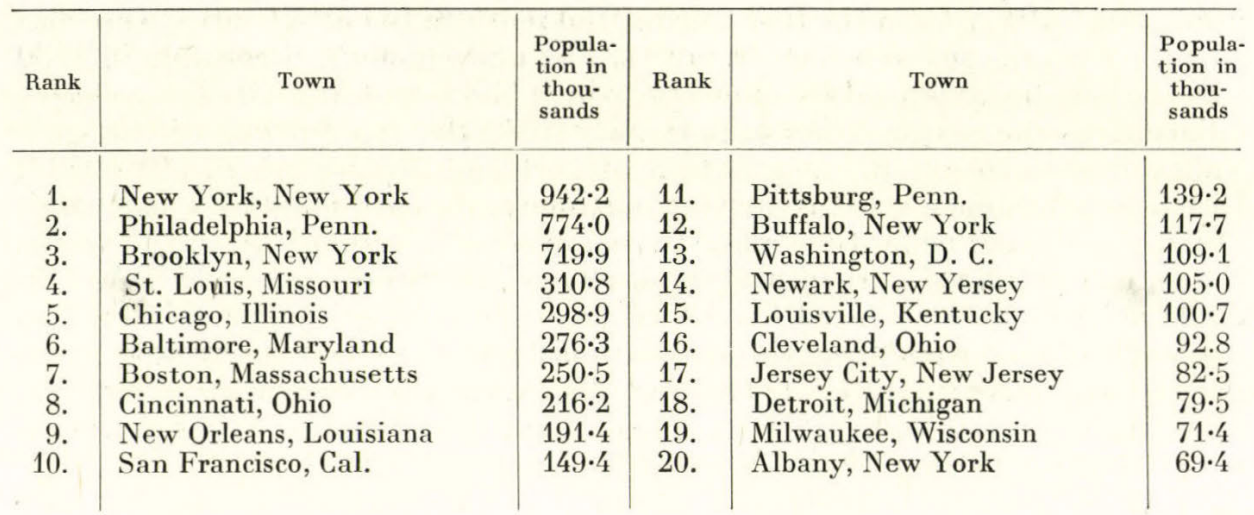

The combination of commerce and industry is striking indeed. Ports still dominated - the first twelve towns began as significant ports, even though industry within those places had, by 1870, inflated the town's population. Of the eight remaining in the list, only Washington grew at a site not originally a port. Thus, it seems reasonable to argue that large towns in America remained on the sites of speculative places that were also ports. One important force was only beginning to be perceived in 1870 that was the role of the railroad.

To understand why the railroad, thirty-five years after the first significant lines were opened, was still not a dominant force in "city filling" several points need be made. To begin with the railroads were in actuality extensions of the water-borne transportation system where nature did not provide. The first rail lines were built from the colonial ports into their hinterlands - three separate lines from Boston to Lowell, Worcester, and Providence, each opened in 1835; two lines from Philadelphia respectively to the Susquehanna River at Columbia and New York Harbor at Perth Amboy, both opened in 1834; a single line from Baltimore leading toward the Ohio River, begun in 1827 and finished to Wheeling on the river in 1853; and a single line from the port of Charleston inland to tap the Savannah River at Hamburg, which when completed in 1833 was the longest railroad in the world. These lines tapped the immediate region of the port, sometimes as with the line to Lowell, to Columbia, and to Hamburg seeking to divert the water-borne commerce of one port to the harbor of a different city. But the towns had been sited as a result of a previous generation of transportation so the first rail lines interconnected existing places, much as did those of Europe where the number of important "railroad towns" can be counted on one hand.

Only as rail building overtook the settlement frontier did the railroad begin to play a significant role in creating rather than filling towns. Even Chicago, commonly vaunted as the world's greatest railroad town, began under other auspices when, in the 1830's, the speculators descended upon the mouth of the Chicago River, a minor stream flowing into Lake Michigan (which had 
been selected by the builders of the Illinois and Michigan Canal as the canal port on the Great Lakes where their waterway would begin) there laying out a "potential town" on a vile site subject to bad drainage and recurrent flooding. Thus, Chicago's early growth was that of a speculator's town at the beginning of a canal. As was the case in the East Coast ports, Chicago's first railroads were projected inland from the lake port to tap its hinterland. So, as the railroads from the East were building westward, they found at Chicago the nexus of an already existing local system sufficient to make end-to-end connection desirable. With that connection on a massive scale Chicago grew rapidly; but it should be appreciated that because the two rail systems were initially separate - those to the east and those to the west - they have tended to remain so to this day. Trains pass over lines continuous from the East Coast to Chicago but there they are transferred to other lines thence continuous to the West Coast. If Chicago had not predated the coming of the railroads, it is doubtful that it would have formed the connecting point it did, and thereby have gained the vast railroad-related employment that it did, which made Chicago the largest city of the interior by 1875. As the juncture of the rail lines, it gained in addition a great component of industrial employment which further expanded the city's population.

Industrialization shows up clearly in the census figures for 1870. The important ports had brought railroads to themselves, and in turn the railroads had further encouraged industrialization in these hubs of long-distance transportation and trade. ALLAN PRED has clearly shown this conjunction of forces, so all we need add is to emphasize the distinction between the colonial and early independence city. The colonial city was initially and still, until the middle of the last century, remained dominantly the creation of a long-distance mercantile trading system - thus fundamentally a commercial town. The mid-nineteenth century city which succeeded on the same site - through adding rail ties to the port it offered a great potential for industrialization became fundamentally a commercial site with an industrial enlargement. In this way there was laid the foundation for the giant metropolises that began to be clearly developed during the years just before the First World War. At the same time the demands for industry in the United States were so great that not all manufacturing could be contained within the older important towns. The speculator's "potential towns" and the vastly extending railroads afforded to many potential places the chance for growth of industry, particularly as improved external connections encouraged dispersal of industrial development. To a degree that was absent in Europe (outside of northern France, Belgium and the Ruhr district) industrialization in America reached out into the smaller cities shaping a vastly extensive Manufacturing Belt that STEN DE GEER and other geographers spent much effort in studying in the 1920 's and 30's. This wide spread of economic development owed far more than is ever acknowledged to the contributions of the town speculator and the competitive overbuilding of rail lines in the United States.

We should not forget that in 1850 when there were only 603 kilometers (375 miles) of rail in Austria and 224 kilometers (139 miles) in Hungary, there were already 9,072 miles $(14,597$ kilometers) in the United States, nearly 40 per cent of the world's total. By 1870 that mileage in the United States 
had risen to 53,000 miles $(85,277 \mathrm{~km})$ comprising a mileage twice that of the Austro-Hungarian Empire at the outbreak of the First World War. By the outbreak of that war, the United States had multiplied its own rails to over a quarter of a million miles $(400,000 \mathrm{~km})$ or to ten times the length of line in Austria-Hungary and still about 40 per cent of the world's mileage. Vast as the total area of the United States might be, in many parts of the North East and Middle West the actual density of lines was as high as that in western Europe, and in New England as high as in Belgium and Britain.

\section{THE RAILROAD METROPOLIS IN THE UNITED STATES}

In the part of the country where the advance of the settlement frontier and the construction of railroads went hand in hand - that is the area to the west of the Mississippi River (with the exception of Missouri and Texas) - most towns were railroad creations save for those mining camps developed often far ahead of the frontier. There was more than a coincident relationship between town-speculation and rail-building in this vast region. In most cases the railroad companies set out towns near their line and on lands they had gained by government grant or actual purchase. On many occasions the profits from those operations made available the capital that built the railroad; and certainly in many cases it was the chance to participate in those land speculations fostered by the railroad companies which brought construction capital into the companies themselves. In other cases land speculators invested heavily in railroad companies in the interest of securing a rail connection or even the diversion of a main line under construction in the direction of their town development. Finally, it became obvious that a town without a rail line was a town that was consigned to stagnation. In such a development climate the nascent "City of Los Angeles" paid the Southern Pacific Railroad a quarter million dollars to carry its line south, rather than north, of the San Gabriel Mountains so as to pass through the town in 1876.

Because of this two-way operation of town-speculation supporting railroadbuilding, and the railroad the town, the location of railroads became critical to the growth of towns. There might be some encouragement of a town by a single rail line but for a town to rise to metropolitan status meant gaining convergence there of a number of lines and routes. This fact led to a somewhat unexpected situation, which was that in the West at the time of the railroad building era the tie between rail-building and town-founding was close and real. But it was equally true that to secure the multiplicity of lines that would assure metropolitan status, it was highly desirable to have had a pre-rail development which would draw those lines toward the site without having to depend on the land the attraction of a site so nude that the only magnet was speculation tie. The reason was simple. Only one railroad and land speculator could set up such a town founding tie. All later-comers would have to settle for entering a place where they were denied the incremental profits to be secured from land speculation. If they could not gain that additional return, they would then seek to avail themselves of gain from an existing market, however, small it might be. Thus, the mining camps of the West exerted an 
influence on railroad routing out of all proportion to their actual economic importance.

The result of these conditions was the creation of a two-tier system of towns in the interior of the United States. The oldest places in time of founding were the river and lake ports of the area east of the Mississippi River and the mining camps of the West. These were the long-distance targets of rail lines built through their respective areas. In between those pre-rail foci most urbanization depended upon the close symbiosis of rail-building and townspeculation.

\section{RAILROADS, LAND SPECULATION}

\section{AND CENTRAL-PLACE THEORY}

There was a result of that rail-town tie that is of particular interest to geographers. The railroads were so strongly attached to the notion of gaining profit from town founding that they laid out urban settlements at as frequent an interval as possible along their respective lines. In the specific case of the state of Iowa there were a number of lines run across the state from the Mississippi River on the eastern boundary to the Missouri River on the west. These lines, depending in part on landgrants, were run in a strongly latitudinal alignment some thirty to forty miles apart. With a spacing of "potential towns" seven to ten miles apart (east-west) along the lines (at rail stations commonly that distance from one another), there came into being a highly geometric net of "potential towns". This was a situation very different from the norm in America and dependent upon the peculiar historical background of railroad building in the state.

To understand the historical context of such construction in Iowa we should keep in mind that the national government set out in the 1860's to have a transcontinental railroad completed as soon as possible. In order to avoid favoring one of the railroads that had been built into the interior from the East, President Abraham Lincoln determined the eastern terminus of the transcontinental line, the Union Pacific, as being located on the western boundary of Iowa at Council Bluffs. When that terminus was established there was no railroad within several hundred miles of the site but there were a number of lines already built to or just across the Mississippi River into eastern Iowa. These had been the original lines of rail constructed from the canal port of Chicago westward which by the early 1860's had reached the Mississippi: the Illinois Central Railroad at Dunleith (opposite Dubuque, Iowa) was finished by 1855; the Rock Island Railroad to Rock Island and Davenport, Iowa, in 1854; the Chicago, Burlington and Quincy Railroad to Burlington, Iowa, in 1855; and to Quincy, Illinois, in 1856. Thus there were four companies ready to build from the Mississippi to the Council Bluffs terminus when it was announced in 1862. And build they did, parallel across Iowa following as if by natural law the lines of latitude.

It was this railroad rush to make connection with the transcontinental line, which opened in 1869, as well as the desire to create speculators' towns on the companies' land grants in Iowa, or in conjunction with other owners willing 
to give to the railroad a participation in their operations, that shaped the peculiar and untypical pattern of town locating in Iowa. Thus, the recent attempts to prove the validity of the Christaller system in the United States, which usually rest so heavily on evidence from Iowa, represent instead of actual proof the extraction of an assumed general truth from a very special case.

\section{AMERICA IN 1910}

By the time another forty years had passed, that is when the census of 1910 was taken, the possibility of change through new rail building was essentially foreclosed. The last transcontinental railroads were opened, the Chicago, Milwaukee, and Pacific to Seattle in 1909 and the Western Pacific Railroad to Oakland (San Francisco) in 1910. In neither case was an essentially new service offered so it seems correct to argue that the 1910 census reflected the conditions at the close of the railroad era and when the rail-based metropolis was most dominant (Table IV).

TABLE IV

The twenty great towns of the United States in 1910

\begin{tabular}{c|l|r|l|l|c}
\hline Rank & \multicolumn{1}{|c|}{ Town } & $\begin{array}{r}\text { Popula- } \\
\text { tion in } \\
\text { thousands }\end{array}$ & Rank & Town & $\begin{array}{c}\text { Popula- } \\
\text { tion in } \\
\text { thousands }\end{array}$ \\
\hline & New York, N.Y. & $4,766 \cdot 8$ & 11. & San Francisco, Cal. & $416 \cdot 9$ \\
1. & Chicago, Ill. & $2,185 \cdot 2$ & 12. & Milwaukee, Wis. & $373 \cdot 8$ \\
3. & Philadelphia, Penn. & $2,071 \cdot 6$ & 13. & Cincinnati, Ohio & $363 \cdot 5$ \\
4. & St. Louis, Mo. & $687 \cdot 0$ & 14. & Newark, N. J. & $347 \cdot 4$ \\
5. & Boston, Mass. & $670 \cdot 5$ & 15. & New Orleans, La. & $339 \cdot 0$ \\
6. & Cleveland, Ohio & $560 \cdot 6$ & 16. & Washington, D. C. & $331 \cdot 0$ \\
7. & Baltimore, Md. & $558 \cdot 4$ & 17. & Los Angeles, Cal. & $319 \cdot 1$ \\
8. & Pittsburgh, Penn. & $533 \cdot 9$ & 18. & Minneapolis, Minn. & $301 \cdot 4$ \\
9. & Detroit, Mich. & $465 \cdot 7$ & 19. & Kansas City, Mo. & $248 \cdot 3$ \\
10. & Buffalo, N. Y. & $423 \cdot 7$ & 20. & Seattle, Wash. & $237 \cdot 1$ \\
& & & & &
\end{tabular}

By this year the population figures for cities had begun to lose their accuracy in reflecting the relative rank of metropolitan areas. The outward spread of urban residents into the countryside that had originally surrounded them was on such a scale that the population of the core city alone gave a false impression, rather in the way taking the size of Pest as a measure of this metropolis did before its joining with Buda. In America it was an almost universal phenomenon that suburban development came to house most of the population growth of the city after the First World War.

But before turning to look at the internal structure of American metropolises we should complete our rough summary view of the broad geographical location of the larger places. In 1910 the last of the places created by the railroad began to show up within the ranks of the twenty largest cities. From 
1909 on Seattle at the Pacific end of the "northern lines" of railroad had three lines across the continent as had Los Angeles in the southwest after the completion of the Los Angeles and Salt Lake Railroad in 1905. And Minneapolis and Kansas City became great milling centers, at the eastern edge of the Great Plains, particularly after Hungarian milling machinery first developed in Pest around 1840 came into use in these emerging cities where railroads from the western wheat fields came together with the trunk lines leading to eastern and European markets. It should be noted as well that Buffalo in western New York state showed a similar growth because of its long-standing and large role in flour milling which, with the vast expansion of wheat farming in the late nineteenth century, became a leading American industry.

Throughout the development of American cities there was a strong component of industrialization either at the time the town was founded or subsequently in the nineteenth century as the national industrial economy developed. In the early part of the twentieth century it is valid to argue that any major city must be a manufacturing place or else a great emporium of trade, with trade able to support only a moderate sized town. Looking at these twenty largest eities for 1910 the truth of that statement shows up clearly. The ten largest towns were all places of complex support - longdistance trading towns to begin with that had subsequently been enlarged considerably in population by the nineteenth century introduction of factories and industrial workers. In the second ten cities (11 to 20 in rank) it was the fact that only one of the two main supports for American metropolitan growth tended to be dominant, with the other standing in a somewhat truncated form, which placed these cities behind the leaders. San Francisco, New Orleans, Los Angeles and Seattle were heavily dominated by long-distance trade and only partially developed for industry. In turn, Milwaukee, Cincinnati, Newark, Minneapolis, and Kansas City were more manufacturing places than great distant trades. And Washington was unique, as perhaps the world's most politically dominated city. From all of this we may reasonably conclude that the greatest cities of America must of necessity be complex places, but that the metropolis could begin to show of development based on a dominant role in only one of the city-filling activities.

There seems little virtue in attempting a detailed consideration of the twenty largest towns in 1950 and 1970 which are given in Table $\mathrm{V}$. There were shifts in ranking and a few additions or removals, consideration of which can tell the main story.

For the first time in 1970 there seems some evidence of a balancing process at work among the large cities of the country. The greatest towns were stable or even declining in population. When in 1971 the municipal government of New York City questioned the small growth of population shown in the 1970 census a new special census was conducted, only to show that in fact the city had declined below its total for 1950 joining the other great towns a slowly declining state. In general it was the cities of the southern tier of states - Los Angeles and San Diego in California, Houston, Dallas and San Antonio in Texas, Memphis in Tennessee and Phoenix (Arizona), Atlanta (Georgia) and the Florida cities - which grew rapidly, though not to the top rank in total population. 


\section{TABLE V}

The twenty great towns of the United States in 1950 and 1970

\begin{tabular}{c|l|r|l|r}
\hline Rank & Town in 1950 & $\begin{array}{c}\text { Population } \\
\text { in } \\
\text { thousands }\end{array}$ & Town in 1970 & $\begin{array}{c}\text { Population } \\
\text { in } \\
\text { thousands }\end{array}$ \\
\hline 1. & New York, N. Y. & $7,891 \cdot 9$ & New York, N. Y. & $7,894 \cdot 8$ \\
2. & Chicago, Ill. & $3,620 \cdot 9$ & Chicago, Ill. & $3,366 \cdot 9$ \\
3. & Philadelphia, Penn. & $2,071 \cdot 6$ & Los Angeles, Cal. & $2,816 \cdot 0$ \\
4. & Los Argeles, Cal. & $1,970 \cdot 3$ & Philadelphia, Penn. & $1,948 \cdot 6$ \\
5. & Detroit, Mich. & $1,849 \cdot 5$ & Detroit, Mich. & $\mathbf{1 , 5 1 1 \cdot 4}$ \\
6. & Baltimore, Md. & $949 \cdot 7$ & Houston, Texas & $1,232 \cdot 8$ \\
7. & Cleveland, Ohio & $914 \cdot 8$ & Baltimore, Md. & $905 \cdot 7$ \\
8. & St. Louis, Mo. & $856 \cdot 7$ & Dallas, Texas & $844 \cdot 4$ \\
9. & Washington, D. C. & $802 \cdot 1$ & Washington, D. C. & $756 \cdot 5$ \\
10. & Boston, Mass. & $801 \cdot 4$ & Cleveland, Ohio & $750 \cdot 9$ \\
11. & San Francisco, Cal. & $775 \cdot 3$ & Indianapolis, Ind. & $744 \cdot 6$ \\
12. & Pittsburgh, Pa. & $676 \cdot 8$ & Milwaukee, Wis. & $717 \cdot 0$ \\
13. & Milwaukee, Wis. & $637 \cdot 3$ & San Francisco, Cal. & $715 \cdot 6$ \\
14. & Houston, Texas & $596 \cdot 1$ & San Diego, Cal. & $696 \cdot 7$ \\
15. & Buffalo, N. Y. & $580 \cdot 1$ & San Antonio, Texas & $654 \cdot 1$ \\
16. & New Orleans, La. & $570 \cdot 4$ & Boston, Mass. & $641 \cdot 0$ \\
17. & Minneapolis, Minn. & $521 \cdot 7$ & Memphis, Tenn. & $623 \cdot 5$ \\
18. & Cincinnati, Ohio & $503 \cdot 9$ & St. Louis, Mo. & $622 \cdot 2$ \\
19. & Seattle, Wash. & $467 \cdot 5$ & New Orleans, La. & 593.4 \\
20. & Kansas City, Mo. & $456 \cdot 6$ & Columbus, Ohio & $539 \cdot 6$ \\
& & & & \\
& & & &
\end{tabular}

Beyond this matter of the southward turn of American urbanization there was also a decline in the ranking of the ports that had been the original metropolises and a rise for either newer ports (Houston) or for complex trading and manufacturing towns.

\section{THE GROWTH OF METROPOLITANISM}

There are two aspects of metropolitanism in the United States that must concern us: the first is the number of metropolitan places and the second, the geographical distribution of those places (Table VI).

From these figures showing the number of "large" and "great" towns in the United States it is clear that the pattern which has evolved since 1850, when the first American city, New York, reached a population of half a million, is one of a considerable number of truly "large places" but a relatively small number of "great cities".

This observation reflects a political rather than a demographic fact. Rapid and large urbanization came to America only in the middle of the last century. At that time it was still accepted practice in American cities for the physical growth of the city to be accompanied by the physical extension of the boundaries of the municipality. In this practice American cities expanded politically much as did London and a number of the great towns of Europe, where a group of strong central governments decreed such an expansion. In America 
TABLE VI

Number of large and great towns

\begin{tabular}{|c|c|c|c|}
\hline Years of census & $\begin{array}{c}\text { Number of } \\
\text { large towns } \\
(500,000 \text { to } \\
999,999)\end{array}$ & $\begin{array}{c}\text { Number of } \\
\text { great towns } \\
(1,000,000 \text { and } \\
\text { over })\end{array}$ & $\begin{array}{l}\text { Total number of } \\
\text { metropolises }\end{array}$ \\
\hline 1850 & 1 & - & 1 \\
\hline 1860 & 2 & - & 2 \\
\hline 1870 & 2 & - & 2 \\
\hline 1880 & 3 & 1 & 4 \\
\hline 1890 & 1 & 3 & 4 \\
\hline 1900 & 3 & 3 & 6 \\
\hline 1910 & 5 & 3 & 8 \\
\hline 1920 & 9 & 3 & 12 \\
\hline 1930 & 8 & 5 & 13 \\
\hline 1940 & 9 & 5 & 14 \\
\hline 1950 & 13 & 5 & 18 \\
\hline 1960 & 16 & 5 & 21 \\
\hline 1970 & 26 & 6 & 26 \\
\hline
\end{tabular}

the areal growth of cities came in response to the widespread desire for many persons to live "within" a city where the schools, municipal services and a number of other undertakings were viewed as superior to those found in the country. But by the end of the last century the climate of opinion had shifted - large cities were considered, both in terms of health and political conditions, undesirable places to live; so new suburban areas proved very reluctant to join politically with the central city. The result was a slowing down of the increase in numbers of great cities but a rapid expansion in those of large size $(500,000$ to 999,999$)$ as a further expansion of the population of major metropolises took place outside the central city and therefore did not show up in its ranking and as the leading towns of other regions became larger. From soon after 1900 the geographical limits of the older cities were constrained, much as those of Paris were until the 1920's, but in the American case by the resistence of outside places to inclusion in the city rather than the fortifications that contained the French capital.

\section{THE URBANIZED AREA}

Once the central cities could no longer grow by the expansion of their city boundary, a different measure of metropolitanization was needed. Various metropolitan "districts", "areas", "statistical areas", and "daily urban systems" have been proposed, but by far the most consistent and rational is what has come to be known as the "urbanized area" whose limits are those of the contiguous built-up area of the city. All other metropolitan areas are so inconsistent from one part of the country to another as to lack very much true comparability. Brian L. BerRy sought, after the 1970 census, 'to in- 
troduce a new measure, the "Daily Urban System" seeking to measure the movement of people from one county to another in a daily commuting flow, but his results are as inconsistent and open to criticism for variability as the others, so I will turn instead to the best available fairly consistent measure, the Urbanized Area.

\section{THE RANKING OF URBANIZED AREAS IN AMERICA}

One of the great virtues of the urbanized area is the chance it affords us for comparison with metropolitanism in other countries. Most nations have some sort of statistical unit which is essentially conterminous with the physically built-up city. In the United States this is the Urbanized area.

Perhaps we may best begin by looking at the twenty-five largest urbanized areas, there being 248 for the country as a whole, with 148 having more than 200,000 people (Table VII).

\section{Table VII}

Urbanized areas of one million or more

\begin{tabular}{|c|c|c|c|c|c|}
\hline Rank & Urbanized area & $\begin{array}{l}\text { Population } \\
\text { in } \\
\text { thousands }\end{array}$ & Rank & Urbanized area & $\begin{array}{l}\text { Population } \\
\text { in } \\
\text { thousands }\end{array}$ \\
\hline 1. & New York-Northeast & $16,206 \cdot 0$ & 12. & Pittsburgh, Penn. & $1,846 \cdot 0$ \\
\hline 2. & $\begin{array}{l}\text { New Jersey } \\
\text { Los Angeles-Long }\end{array}$ & $8,351 \cdot 0$ & 13. & $\begin{array}{l}\text { Minneapolis-St. Paul, } \\
\text { Minnesota }\end{array}$ & $1,704 \cdot 0$ \\
\hline & Beach, Cal. & & 14. & Houston, Texas & $1,677.0$ \\
\hline 3. & Chicago-Northwest & $6,714 \cdot 0$ & 15. & Baltimore, Maryland & $1,579.0$ \\
\hline & Indiana, Ind.-Ill & & 16. & Milwaukee, Wisconsin & $1,252 \cdot 0$ \\
\hline 4. & Philadelphia, Penn.-N.J. & $4,021 \cdot 0$ & 17. & Seattle-Everett, Wa & $1,238 \cdot 0$ \\
\hline 5. & San Francisco-Oakland, & $4,013 \cdot 0$ & 18. & Miami, Florida & $1,219 \cdot 0$ \\
\hline & San Jose, Cal. & & 19. & San Diego, Cal. & $1,198 \cdot 0$ \\
\hline 6. & Detroit, Mich. & $3,970 \cdot 0$ & 20. & Atlanta, Ga & $1,172 \cdot 0$ \\
\hline 7. & Boston, Mich. & $2,652 \cdot 0$ & 21. & Cincinnati, O.-Ky. & $1,110 \cdot 0$ \\
\hline 8. & Washington, D. C. & $2,481 \cdot 0$ & 22 . & Kansas City, Mo.-Kas. & $1,101 \cdot 0$ \\
\hline 9. & Dallas-Ft. Worth, Tex. & $2,015 \cdot 0$ & 23. & Buffalo, N. Y. & $1,086 \cdot 0$ \\
\hline 10. & Cleveland, Ohio & $1,959 \cdot 0$ & 24. & Denver, Colo. & $1,025 \cdot 0$ \\
\hline 11. & St. Louis, Mo.-Ill. & $1,882.0$ & 25 . & $\begin{array}{l}\text { San Jose, Cal, lumped } \\
\text { with San Francisco- } \\
\text { Oakland) }\end{array}$ & $1,025 \cdot 0$ \\
\hline
\end{tabular}

Applying the general standards of size employed to the central city data from earlier times the following breakdown of urbanized areas, by population, in the United States emerges (Tables VIII, IX and $X$ ). 


\section{TABLE VIII}

Population classes of urbanized areas,

by geographical areas in 1970

\begin{tabular}{|c|c|c|c|c|c|c|c|c|c|c|}
\hline \multirow[b]{2}{*}{ Class } & \multirow[b]{2}{*}{ Population limits } & \multicolumn{8}{|c|}{ Census geographical divisions of the United States } & \multirow[b]{2}{*}{ Pacific } \\
\hline & & $\begin{array}{l}\text { New } \\
\text { England }\end{array}$ & $\begin{array}{l}\text { Middle } \\
\text { Atlantic }\end{array}$ & $\begin{array}{l}\text { East-North } \\
\text { Central }\end{array}$ & $\begin{array}{c}\text { West-North } \\
\text { Central }\end{array}$ & $\begin{array}{c}\text { South } \\
\text { Atlantic }\end{array}$ & $\begin{array}{l}\text { East-South } \\
\text { Central }\end{array}$ & $\begin{array}{c}\text { West-South } \\
\text { Central }\end{array}$ & Mountain & \\
\hline $\begin{array}{l}\text { Great City } \\
\text { Large City } \\
\text { Major City } \\
\text { Full City } \\
\text { Small City } \\
\text { Semi-City }\end{array}$ & $\begin{array}{l}1,000,000 \text { or more } \\
500,000-999,999 \\
250,000-499,999 \\
150 \cdot 000-249,999 \\
100,000-149,000 \\
50,000-99,000\end{array}$ & $\begin{array}{r}1 \\
2 \\
3 \\
5 \\
6 \\
8 \\
25\end{array}$ & $\begin{array}{r}4 \\
1 \\
4 \\
7 \\
3 \\
3 \\
22\end{array}$ & $\begin{array}{r}5 \\
4 \\
5 \\
11 \\
8 \\
16 \\
49\end{array}$ & $\begin{array}{r}3 \\
4 \\
1 \\
5 \\
7 \\
20\end{array}$ & $\begin{array}{r}4 \\
3 \\
8 \\
12 \\
5 \\
8 \\
40\end{array}$ & $\begin{array}{r}- \\
3 \\
2 \\
6 \\
3 \\
3 \\
17\end{array}$ & $\begin{array}{r}2 \\
4 \\
3 \\
3 \\
4 \\
21 \\
37\end{array}$ & $\begin{array}{r}1 \\
1 \\
3 \\
2 \\
3 \\
5 \\
15\end{array}$ & $\begin{array}{r}5[25] \\
3[25] \\
3[35] \\
4 \quad[51] \\
3[40] \\
5[76] \\
23[248]\end{array}$ \\
\hline $\begin{array}{l}\text { Population } \\
\text { (in tho } \\
\text { U.S. Total }\end{array}$ & $\begin{array}{l}\text { Is) } \\
203,212\end{array}$ & 11,842 & 37,199 & 40,252 & 16,319 & 30,671 & 12,803 & 19,321 & 8,282 & 26,523 \\
\hline
\end{tabular}




\section{TABLE IX}

Average population served by cities of a particular class, by census divisions

(Cities of all larger classes are included in the count of cities of a particular class)

\begin{tabular}{|c|c|c|c|c|c|c|c|c|c|}
\hline & $\begin{array}{c}\text { New } \\
\text { England }\end{array}$ & $\begin{array}{c}\text { Middle } \\
\text { Atlantic }\end{array}$ & $\begin{array}{l}\text { East-North } \\
\text { Central }\end{array}$ & $\begin{array}{l}\text { West-North } \\
\text { Central }\end{array}$ & $\begin{array}{l}\text { South } \\
\text { Atlantic }\end{array}$ & $\begin{array}{l}\text { East-South } \\
\text { Central }\end{array}$ & $\begin{array}{l}\text { West-South } \\
\text { Central }\end{array}$ & Mountain & Pacific \\
\hline $\begin{array}{l}\text { Great City } \\
\text { Large City } \\
\text { Major City } \\
\text { Full City } \\
\text { Small City } \\
\text { Semi-City }\end{array}$ & $\begin{array}{r}11,842 \\
3,947 \\
1,974 \\
1,077 \\
687 \\
474\end{array}$ & $\begin{array}{l}9,00 \\
7,439 \\
4,133 \\
2,325 \\
1,958 \\
1,691\end{array}$ & $\begin{array}{r}8,050 \\
4,472 \\
2,875 \\
1,610 \\
1,220 \\
822\end{array}$ & $\begin{array}{r}5,440 \\
5,400 \\
2,331 \\
2,039 \\
1,255 \\
816\end{array}$ & $\begin{array}{r}7,668 \\
4,382 \\
2,045 \\
1,136 \\
959 \\
767\end{array}$ & $\begin{array}{r}\overline{4,268} \\
2,561 \\
1,164 \\
915 \\
753\end{array}$ & $\begin{array}{r}9,661 \\
3,220 \\
2,147 \\
1,610 \\
1,208 \\
522\end{array}$ & $\begin{array}{r}8,282 \\
4,141 \\
1,656 \\
1,183 \\
828 \\
552\end{array}$ & $\begin{array}{l}5,305 \\
3,315 \\
2,411 \\
1,768 \\
1,474 \\
1,153\end{array}$ \\
\hline
\end{tabular}

Population given in thousands

TABLE X

Ranking of census divisions for average size of population served by a class of city

\begin{tabular}{|c|c|c|c|c|c|c|c|c|c|}
\hline Class of City & $\begin{array}{c}\text { First } \\
\text { (largest) }\end{array}$ & Second & Third & Fourth & Fifth & Sixth & Seventh & Eighth & $\begin{array}{c}\text { Ninth } \\
\text { (smallest) }\end{array}$ \\
\hline $\begin{array}{l}\text { Great City } \\
\text { Large City } \\
\text { Major City } \\
\text { Full City } \\
\text { Small City } \\
\text { Semi-City }\end{array}$ & $\begin{array}{l}\text { New Eng. } \\
\text { M.Atl. } \\
\text { M.Atl. } \\
\text { M.Atl. } \\
\text { M.Atl. } \\
\text { M.Atl. }\end{array}$ & $\begin{array}{l}\text { W.S.C. } \\
\text { W.N.C. } \\
\text { E.N.C. } \\
\text { W.N.C. } \\
\text { Pacific } \\
\text { Pacific }\end{array}$ & $\begin{array}{l}\text { M.Atl. } \\
\text { E.N.C. } \\
\text { E.S.C. } \\
\text { Pacific } \\
\text { W.N.C. } \\
\text { E.N.C. }\end{array}$ & $\begin{array}{l}\text { Mtn. } \\
\text { So.Atl. } \\
\text { Pacific } \\
\text { E.N.C. } \\
\text { E.N.C. } \\
\text { W.N.C. }\end{array}$ & $\begin{array}{l}\text { E.N.C. } \\
\text { E.S.C. } \\
\text { W.N.C. } \\
\text { W.S.C. } \\
\text { W.S.C. } \\
\text { So.Atl. }\end{array}$ & $\begin{array}{l}\text { So.Atl. } \\
\text { Mtn. } \\
\text { W.S.C. } \\
\text { Mtn. } \\
\text { So.Atl. } \\
\text { E.S.C. }\end{array}$ & $\begin{array}{l}\text { W.N.C. } \\
\text { New Eng. } \\
\text { So.Atl. } \\
\text { E.S.C. } \\
\text { E.S.C. } \\
\text { Mtn. }\end{array}$ & $\begin{array}{l}\text { Pacific } \\
\text { Pacific } \\
\text { New Eng. } \\
\text { So.Atl. } \\
\text { Mtn. } \\
\text { W.S.C. }\end{array}$ & $\begin{array}{l}\text { W.S.C. } \\
\text { Mtn. } \\
\text { New Eng. } \\
\text { New Eng. } \\
\text { New Eng. }\end{array}$ \\
\hline
\end{tabular}


We shall see presently that metropolitan places are particularly numerous in the United States as well as being more widely dispersed within the country than in most economically developed nations. For the moment let us take these facts on faith, and seek to discover why such a wide spread of metropolitanism is to be found. The answer lies, I believe, in the economic and social freedom that attended the settlement of America. Even when the rather monopolistic economic practices that governed European settlement in the New World were at work in the colonial period, the existence of thirteen colonies that became the United States reduced the tendency toward geographical concentration typical of the time. Once the nation was independent in 1783 it became the legal as well as the actual practice to permit freedom to individuals both to enter any trade they chose and to move where they would.

To begin with commerce dominated economic thinking in the new nation, only local trade had been relatively unconstrained under the British yoke while long-distance trade and manufacturing were severely repressed; thus it was particularly toward establishing an integrated national commercial system that the first efforts after independence were turned. Men sought both to expand the geographical frontiers of the new nation and to develop a system of long-distance trading cities. Within these places society was mobile and there were many speculators moving along with the frontier, seeking always to gain for themselves the rapid increment of capital formation that successful town planting brought. Thus, there were always plans to urbanize any site with the least possibility for town support. When those plans were joined to nature's system of vast and highly usable rivers and lakes a considerable pattern of towns in the interior of the country emerged. When the railroads came to supplement the inland waterways an even vaster and more uniform pattern of towns might arise so even more speculator's towns might entertain hopes for ultimate success. It was with this combination of speculation and transportation development that the frontier advanced, already at a rapid pace that was even further speeded up by the planting of mining towns, often in unsettled land well ahead of the farmer's frontier. Those mining towns grew not out of the speculation-transportation partnership so nearly universal elsewhere in the United States but instead obviously from mineral occurrences. But once the mining camp was established it proved a powerful magnet to draw transportation lines to itself.

In these ways a set of four basic initiators of towns arose - the colonial merchant's setting up coastal ports that became cities; their descendents' repeating the same process at ports along the wide interior rivers and lakes; still later the railroad builder's seeking to encourage urbanization on lands granted to his company added more cities to an already considerable array; and finally the mining prospector's discovering gold and silver pushed the line of towns well beyond the edge of continuous settlement, though quickly drawing the railroads as well beyond the edge of cultivation to serve the particular mining needs.

On each of these four types of town was grafted manufacturing when the United States became the second nation to "industrialized" and by the end 
of the last century the most extensive practitioner of factory production. Thus, each of the types of city could be filled out by adding great industrial populations to those earlier drawn to the city by its initial purpose. Because it took a succession of purposes to create a true metropolis, it was those places where one activity was joined to one or several others that gained the rank of large or great city. The numerous colonial town settlers, the striving commercial pioneers of the inland waterways, the ever present speculators in land, and those great facilitators of form and continuous city growth, the railroad builders, all contributed to the ubiquity of American metropolitanism. And they did so by first fighting for personal and economic freedom and then earnestly practicing it.

The ubiquity of metropolitanism in America was shaped by the acts of many independently operating individuals working over a period of three hundred years rather than by the application of any economic design, such as WALter Christaller envisaged. Consistently throughout American history - from Boston in 1636 to Prudhoe Bay on Alaska's North Slope at this moment - the town has grown up literally on the frontier and before the often assumed agricultural base for urbanism was at all observable. It is both irrational and unhistoric to think that American urbanism, and thereby metropolitanism, follow such a feudal, European model as that of central-place theory. America's pattern was that of personal and economic mobility not of the "natural economy" and constricted horizon that W. CHRISTALLER constantly perceived as man's norm.

Part of the problem with central-place theory is also its vision of cities supported by a single purpose, that of providing goods and services to customers converging on the central place. In America the pattern is so clearly one of functional succession, of planting a town for one purpose (never as a central place it seems), to have other and equally important purposes be added to the town's support. No single cause creates a metropolis. Even Washington, D. C., which is the most functionally restricted large city in America, serves as a major railroad junction point, as a vast center of cultural and scholarly activity, and as the retailing center for a fairly large tributary area. It was the chance to engage in different activities, as well as the ingenuity to shift interests, that led to metropolitanism in any American city, even the capital.

\section{THE MANIPULATION OF FREEDOM: A SYSTEMjOF CITIES}

What is not always so well understood is that there is no rigidly defined urban structure, what some have called "a system of cities", in the United States. There has been a full acceptance of the notion of evolution within interurban relations, of a legal freedom to develop and change, and of free entry in cityfounding and city-filling by any place or any person seeking admission. This situation has contrasted sharply with conditions in those nations of the world - most of the numbers, in fact - where the geographical restraints so characteristic of medieval feudalism have weighed on subsequent decisions. Centralized authority has been the best guarantee of Mark Jefferson's primate city: and centralized authority can be either monarchical or bureaucratic. 
The kings of France may have created Paris but the bureaucrats keep it as the world's seventh city and the one that perhaps most dominates its nation. President Giscard d'Estaing is clearly concerned with this problem when he seeks to hold cabinet meetings in Lyon, itself a mighty small "second city". In other states, notably the bourgeoise socialist bureaucracies of Scandinavia, this excessive concentration has been a serious problem. Although American urbanization has real and torturing problems, nevertheless in the matter of a democratic pattern of urban development and a healthy system of regional economies the United States seems favored; furthermore it seems to enjoy a geographical justice unknown in most countries, capitalist or socialist.

Before looking at the American pattern of metropolitanism in comparison with the world it might be well to take a single instance of how this adaptation of cities in the United States works in pratical terms. The city of Los Angeles furnishes us a striking example to examine. Los Angeles was planted in the early eighteenth century by the Spanish-Mexican conquerors of California as a point of civil administration for what is today southern California. As such an administrative town it slumbered for a hundred years reaching a population of only 1,600 people in 1850. When the Americans took over they began to develop the cattle ranching of the area with somewhat greater vigor than had previously been practiced but even then the population a hundred years ago was only five thousand when Los Angeles was a true "cow-town". In 1876 a branch of the first transcontinental railroad reached the "town" and a new purpose arose, that of providing a winter resort for the chronically ill coming in Pullman sleeping cars from the East. Their enthusiastic reports of the climate led in the 1880 's to a larger influx of visitors, particularly when competition between the now several transcontinental railroads reached the point that you could buy a ticket from Chicago to Los Angeles, a distance of 2,222 miles $(3,575 \mathrm{~km})$ for as little as one dollar and commonly for ten dollars. Along with those visitors went experimentation with irrigation agriculture for subtropical crops, notably oranges, and the development of an intensive fruit and vegetable cultivation not found elsewhere in the country. By 1890 the city had grown twenty-fold over 1870, to 102,000; an increase that continued, more than doubling by 1910. When economic depression hit much of the American South in the 1930's there was a great migration of quite poor persons to California in search of work, or at least a better climate in which to suffer economic depression. Los Angeles increased by 21 per cent in population during this decade of the 1930's. But with the coming of the Second World War and the rapid and massive industrialization of the Los Angeles area the growth was spectacular, 31 per cent in the 1940's. Even from the vast base then present at the beginning of the 1950's growth was still 26 per cent for that decade, and in the 1960 's it was still 14 per cent. The point to be made is that Los Angeles experienced half a dozen different "boom" periods each for a different purpose and always, as the result of freedom to develop, without the dead hand of a bureaucratic system of cities.

Unfortunately today that period of freedom may be rapidly disappearing due to the creation of a new form of "bureaucracy of capitalism" as expressed in the large conglomerate company, often with multi-national economic interests, which now exercises a control on the location of economic activity 
that verges on the powers of a central bureaucracy as in France or Sweden. Perhaps the greatest challenge that today faces the American economic system is dealing with this form of excessive centralization of control. Certainly one of the more significant problems facing American cities is the role that such "rationalized", centralized, and "footloose" power to locate economic activities will have on a pattern of metropolitanism that has grown out of free entry into activities for individuals and places and a geographical democracy of urbanization.

\section{AMERICAN METROPOLITANISM IN A WORLD CONTEXT}

I hope I have been able to suggest how complexity of support and freedom to develop cities has become a characteristic of American urbanization; and how as a result the distribution of cities of metropolitan stature has been more geographically widespread in the United States than probably any other country. There are sizable cities - those over a million in population - in six of the seven census divisions, and there is as well a full range of cities by size in each of these divisions. This pattern differs from that of Canada and Australia, where regions within the country are under-developed - as in the Canadian Maritime Provinces - or where there are a few large cities but a distinct absence of a descending order of towns - as in Australia.

There is another aspect of metropolitanism that needs consideration: that is the number of such large places, which bears upon the question of social and cultural distinctions between rural and urban populations. In many countries there is sharp conflict between the cosmopolitan and increasingly prosperous metropolitan population and the parochial and economically stagnant rural population. To a considerable degree this is a question of the number and distribution within the country of metropolitan cities.

We have already seen how widespread are such places in the United States. Now we should see how common is this egalitarian distribution. To do so, we may engage in a simple analysis of the world's larger cities. Taking the United Nations Yearbook as a source of information, it is possible to come up with a rough, very rough allbeit, classification of substantial cities. In doing so I have revised the figures for Los Angeles, Chicago, the San Francisco Bay Area and Boston so as to make them more comparable with the data from other countries. Specifically I have joined several Standard Metropolitan Statistical Areas found adjacent in these urban areas so as to define a single geographically continuous city, which the U. S. Census has divided for statistical analytical reasons.

The ranking of all the cities of the world that have a population of one million or more is given in Table XI. Certain observations from this table need emphasis. It should be noted that 60 per cent of the 144 cities over a million occur in the class of 1,000,000 to 1,999,999, leaving 40 per cent for all of the upper range from two to nearly fourteen million. For this reason I have divided the group into "metropolises" (those of one to two million) and "super-metropolises" (two million or larger). Of the later group I am glad to report Budapest is a member, if the smallest of the fifty-five. Twenty per cent of all cities 
over a million fall between two and three million, so this category follows on the million cities in numbers, as might be expected, leaving only a fifth of the metropolitan cities with three million or over. From that figure upward the number in each million increment is small - four in the three millions,

\section{TABLE XI}

Number of cities by population class for countries

\begin{tabular}{|c|c|c|}
\hline \multicolumn{3}{|c|}{ One to two million } \\
\hline Rank & Country & No. of cities \\
\hline 1. & United States & 17 \\
\hline 2. & Soviet Union and China & 8 \\
\hline 3. & India & 5 \\
\hline 4. & Japan & 4 \\
\hline 5. & Italy and United Kingdom & 3 \\
\hline 6. & Brazil, Colombia, Federal Rep. of & \\
\hline & $\begin{array}{l}\text { Germany, Indonesia, Korea, Mexico, } \\
\text { Netherlands and Portugal }\end{array}$ & 2 \\
\hline 7. & Austria, Belgium, Burma, Canada, Cuba, & \\
\hline & $\begin{array}{l}\text { Czechoslovakıa, Denmark, German } \\
\text { Dem. Rep., France, Iraq, Morocco, }\end{array}$ & \\
\hline & Nigeria, Pakistan, Philippines, Poland, & \\
\hline & Romania, South-África, Spain, Sweden, & \\
\hline & $\begin{array}{l}\text { Taiwan, Thailand, Uruguay, South- } \\
\text { Vietnam and Zaire }\end{array}$ & 1 \\
\hline
\end{tabular}

Number of cities by population class for countries

\begin{tabular}{|c|c|c|}
\hline \multicolumn{3}{|c|}{ Two to three million } \\
\hline Rank & Country & No. of cities \\
\hline 1. & United States & 6 \\
\hline 2. & China & 4 \\
\hline 3. & Australia, Canada and United Kingdom & 2 \\
\hline 4. & $\begin{array}{l}\text { Chile, Columbia, Federal Rep. of Germany, } \\
\text { Hungary, Italy, Japan, Peru, Singa- } \\
\text { pore, Turkey and Venezuela }\end{array}$ & 1 \\
\hline
\end{tabular}

Number of cities by population class for countries

\begin{tabular}{|c|c|c|}
\hline \multicolumn{3}{|c|}{ Three million and over } \\
\hline Rank & Country & No. of cities \\
\hline 1. & United States & 6 \\
\hline 2. & India & 4 \\
\hline 3. & China & 3 \\
\hline 4. & Brazil, Japan and Soviet Union & 2 \\
\hline 5. & $\begin{array}{l}\text { Argentina, Egypt, France, Indonesia, } \\
\text { Korea, Mexico, Spain and United } \\
\text { Kingdom }\end{array}$ & 1 \\
\hline
\end{tabular}


eight in the four millions, three in the five millions, then with a gap in the six millions but with five in the seven millions, four in the eight's, and then one at ten, another at eleven, and the largest standing at 13,856,000.

If we examine the nationality of these various cities we find the following picture.

The domination of "metropolitanism" by the United States could not be clearer. Both in terms of the three broad classes - metropolitan, super-metropolitan, and even more dominantly super-metropolitan - the United States is the leader in every class, and by a factor of 1.5 or 2.0 to 1.0 . In total number of large cities, even taking into account that the total American population is less than that of China, India, or the Soviet Union (in the case of China and India by almost two-thirds), the United States has nearly twice as many large cities as China (29 to 15), nearly three times as many as the Soviet Union (29 to 10) and India (29 to 9). Even Japan, Brazil, Indonesia, and Pakistan (before partition) all with populations essentially half that of the United States still had respectively 7, 3, 3, and 1 cities of a million or more.

It seems that, by whatever measure employed, the United States is the most strongly metropolitan of countries. Both in terms of the distribution of such important cities within the country and in terms of the number of great cities in the world the impact of the metropolis is greatest in the United States. This fact leaves us with three questions which require an answer, however brief it must be in a short paper such as this. The first is why has metropolitanism come to dominate American life above that of any other country? The second is what is the geographical form that the metropolis has taken on in this, its most evolved utilization? And thirdly, we must ask what are the likely future developments in metropolitanism to judge from conditions at present or impending in the United States?

In a sense we have already answered the question why metropolitanism has come to dominate American life. This domination is not so much a case of the proportion of the population living in the 29 great cities (39 per cent) as it is the presence of metropolitanism in all parts of the country. Sharply in contrast, France's equivalent metropolitan population is only 16.5 per cent; in the Soviet Union it is 9 per cent and in China 6.8 per cent. Only such dominantly urban countries as the United Kingdom approach the percentage metropolitan encountered in the United States, 30.5 per cent, but even there the geographical distribution of metropolitan cities is far more concentrated than in America.

The origin of this geographically dispersed and numerical weighty metropolitanism in America has here been sketched so all that we need do is to summarize the forces at work. Contrary to numerous historical misconceptions, American history began cast strongly in a mercantile role: and contrary to the geographical misconceptions of central-place theorists cities were initial features in American life and fully as fundamental an element in economic structure and development as were fields and forests. Thus, there was the human will and the economic practice of laying out and encouraging cities throughout American history and in all parts of the national realm as it came into settlement. A region without a city was so unthinkable that most of the "West" as it developed was urban before it was in any sense "rural" or "bucolic". 
TABLE XII

Super-metropolitan cities of the world

\begin{tabular}{|c|c|c|c|c|c|}
\hline $\begin{array}{l}\text { Pop. } \\
\text { rank }\end{array}$ & City & $\begin{array}{l}\text { Pop. in } \\
\text { thousands }\end{array}$ & $\begin{array}{l}\text { Pop. } \\
\text { rank }\end{array}$ & City & $\begin{array}{l}\text { Pop. in } \\
\text { thousands }\end{array}$ \\
\hline 1. & Tokyo-Yokohama & 13,856 & 43. & Manchester & 2,368 \\
\hline 2. & New York & 11,571 & 44. & St. Louis & 2,363 \\
\hline 3. & Shanghai & 10,820 & 45. & Caracas & 2,175 \\
\hline 4. & Mexico City & 8,590 & 46. & W. Berlin & 2,122 \\
\hline 5. & Los Angeles & 8,453 & 47. & Chunking & 2,121 \\
\hline 6. & Buenos Aires & 8,353 & 48. & Baltimore & 2,071 \\
\hline 7. & Paris & 8,197 & 49. & Singapore & 2,075 \\
\hline 8. & Chicago & 7,612 & 50. & Lahore & 2,073 \\
\hline 9. & Peking & 7,570 & 51. & Cleveland & 2,065 \\
\hline 10. & London & 7,418 & 52. & Nagoya & 2,052 \\
\hline 11. & Moscow & 7,300 & 53. & Istambul & 2,043 \\
\hline 12. & Calcutta & 7,031 & 54. & Alexandria & 2,032 \\
\hline 13. & Bombay & 5,971 & 55. & Budapest & 2,027 \\
\hline 14. & Seoul & 5,536 & 56. & Houston & 1,985 \\
\hline 15. & Sao Paulo & 5,187 & 57. & Vereeniging & 1,970 \\
\hline 16. & Cairo & 4,961 & 58. & Pusan & 1,880 \\
\hline 17. & Philadelphia & 4,817 & 59. & Canton & 1,840 \\
\hline 18. & Jakarta & 4,576 & 60. & Minneapolis & 1,813 \\
\hline 19. & San Fran. Bay Area & 4,423 & 61. & Saigon & 1,804 \\
\hline 20. & Tientsin & 4,280 & 62. & Hyderabad & 1,796 \\
\hline 21. & Rio de Janeiro & 4,252 & 63. & Hamburg & 1,793 \\
\hline 22. & Detroit & 4,200 & 64. & Taipei & 1,770 \\
\hline 23. & Leningrad & 4,066 & 65. & Kiev & 1,764 \\
\hline 24. & Karachi & 3,650 & 66. & Barcelona & 1,745 \\
\hline 25. & Delhi & 3,647 & 67. & Ahmedabad & 1,742 \\
\hline 26. & Teheran & 3,639 & 68. & Glasgow & 1,728 \\
\hline 27. & Madrid & 3,169 & 69. & Leeds & 1,726 \\
\hline 28. & Boston & 2,985 & 70. & Milane & 1,724 \\
\hline 29. & Osaka & 2,939 & 71. & Rangoon & 1,718 \\
\hline 30. & Washington & 2,861 & 72. & Baghdad & 1,657 \\
\hline 31. & Bogota & 2,818 & 73. & Bangalore & 1,654 \\
\hline 32. & Roma & 2,799 & 74. & Kinshasa & 1,624 \\
\hline 33. & Montreal & 2,743 & 75. & Wien & 1,614 \\
\hline 34. & Sydney & 2,725 & 76. & Lisbon & 1,611 \\
\hline 35. & Santiago & 2,662 & 77. & Bangkok & 1,608 \\
\hline 36. & Toronto & 2,628 & 78. & Dallas & 1,556 \\
\hline 37. & Lima & 2,541 & 79. & Surabaja & 1,556 \\
\hline 38. & Madras & 2,469 & 80. & Harbin & 1,552 \\
\hline 39. & Mukden & 2,411 & 81. & Bucureşti & 1,512 \\
\hline 40. & Pittsburgh & 2,401 & 82. & Pt. Arthur-Dairen & 1,508 \\
\hline 41. & Melbourne & 2,394 & 83. & Lagos & 1,477 \\
\hline 42. & Birmingham & 2,369 & & & \\
\hline
\end{tabular}

This use and respect for cities came considerably, because the city did not gain the same reputation for economic overlordship and cultural artificiality in American life that it had earned in some other nations. There was not in the United States the condescension toward the countryside so widely held among urban Europeans nor the social split between the "leisure class" of politicals and an established aristocracy and the "working classes" of the 


\begin{tabular}{|c|c|c|c|c|c|}
\hline $\begin{array}{l}\text { Pop. } \\
\text { rank }\end{array}$ & City & $\begin{array}{l}\text { Pop. in } \\
\text { thousands }\end{array}$ & $\begin{array}{l}\text { Pop. } \\
\text { rank }\end{array}$ & City & $\begin{array}{l}\text { Pop. in } \\
\text { thousands }\end{array}$ \\
\hline 84. & Tashkent & 1,461 & 114. & Novosibirsk & 1,199 \\
\hline 85. & Kyoto & 1,424 & 115. & Guadalajara & 1,194 \\
\hline 86. & Seattle & 1,422 & 116. & Torino & 1,777 \\
\hline 87. & Nanking & 1,419 & 117. & Montevideo & 1,159 \\
\hline 88. & Milwaukee & 1,403 & 118. & San Bernardino & 1,143 \\
\hline 89. & Manila & 1,399 & 119. & Pondicherry & 1,135 \\
\hline 90. & Atlanta & 1,390 & 120. & Tiangtao & 1,121 \\
\hline 91. & Cincinnati & 1,384 & 121. & Indianapolis & 1,110 \\
\hline 92. & Köbenhavn & 1,380 & 122. & Lyalpur (Pak.) & 1,109 \\
\hline 93. & Casablanca & 1,371 & 123. & Belle Horizonte & 1,107 \\
\hline 94. & San Diego & 1,357 & 124. & Chengtu & 1,107 \\
\hline 95. & Stockholm & 1,352 & 125. & Kuibyshev & 1,094 \\
\hline 96. & Buffalo & 1,349 & 127. & Berlin (GDR) & 1,086 \\
\hline 97. & Warszawa & 1,326 & 128. & Vancouver & 1,082 \\
\hline 98. & Porto & 1,314 & 129. & Taegu & 1,082 \\
\hline 99. & Baku & 1,314 & 130. & Praha & 1,078 \\
\hline 100. & Sian & 1,310 & 131. & Brussels & 1,074 \\
\hline 101. & Kobe & 1,307 & 132. & Lyon & 1,074 \\
\hline 102. & München & 1,294 & 133. & Sverdlovsk & 1,073 \\
\hline 103. & Kharkov & 1,280 & 134. & Rotterdam & 1,065 \\
\hline 104. & Kanpur & 1,275 & 135. & Recife & 1,046 \\
\hline 105. & Memphis & 1,267 & 136. & Kitakyushu (Japan) & 1,046 \\
\hline 106. & Liverpool & 1,262 & 137. & New Orleans & 1,045 \\
\hline 107. & Kansas City & 1,254 & 138. & Amsterdam & 1,032 \\
\hline 108. & Napoli & 1,233 & 139. & Sakai (Japan) & 1,031 \\
\hline 109. & Denver & 1,228 & 140. & Cali & 1,022 \\
\hline 110. & Monterrey & 1,213 & 141. & Taivan & 1,020 \\
\hline 111. & Gorky & 1,213 & 142. & Tampa & 1,012 \\
\hline 112. & Medellin & 1,207 & 143. & Portland (Oregon) & 1,009 \\
\hline 113. & Bandung & 1,201 & 144. & La Habana & 1,009 \\
\hline
\end{tabular}

Source: United Nations Statistical Yearbook, 1970, Table 7.

more productive population without institutionalized rank and distinction. Thus, the city was open to migrants from the countryside throughout American history and there they were not constantly embarrassed by their origins. Moreover, the city as commonly developed the countryside around itself as was true the other way round. And the act of pioneering was as characteristically that of planting a town as of planting the initial corn crop on virgin soil.

Thus, as the frontier advanced city founding came with the first wave. And as the regions developed mainly local cities grew to metropolitan status rather than only New York or Chicago. Almost every region had its "Port Chicago" or "New York of the West" as did the San Francisco Bay Area, not merely in an ironical sense but as an expression of confidence and the justice of regional equality. In the final analysis the concept of "equality" in the United States attached as much to geography as to humanity. The strikingly original contribution of the United States Constitution to the theory of government was the creation, in the Senate, of an instrument of such 
geographical equality. From that act has flowed the metropolitan equality of which we are speaking at the moment.

In such a brief consideration of metropolitanism, as this must be, it has proven impractical to attempt any overall view of the actual physical form of the metropolis. We must be satisfied with a brief note on the tie betwęen the general economic and cultural practices with respect to the rural-urban separation and the form of the metropolis. As noted just now, the social distinction between city and country population was less in America than in Europe: and in addition the countryside lacked the radical social separation that was so commonly associated with the aristocrat-peasant structure of European rural life. Thus, when cities began to grow outward in Europe there was a strong class discontinuity between the ruling group in the land invaded by the city - the aristocracy - and the city people taking up residence there - commonly a very working-class group. It was frequently the view of social class structure in European cities that the most desirable places to live were fairly close to the city center, as in the West End in London and the St. Honore and Roule districts of Paris. The less desirable housing areas were shunted toward the edge of the city, in most intimate contact with the country thereby creating the sharpest discontinuity in society.

The American pattern differed significantly. It had been a constant practice in American cities for the middle classes to move toward the edge of the city, and when public transportation was available, into the near fringe of the country. The American city even a hundred years ago was both characterized by suburbs and made widely varying social use of those open housing areas. The result has been a constant outward spread of cities such that the boundary line between urban and rural morphology is seldom very clear. In the case of the urbanized northeastern United States that Jean Gottmann called "megalopolis" this physical definition of a city is even more obscured. Much or even most of the housing in morphologically rural areas may be occupied by persons commuting each day over a fairly long distance to a major metropolitan city. Thus the urban penumbra around the American metropolis is vast, and becomes essentially continuous between Washington (D. C.) in the south and Boston in the north.

The morphological structure finally becomes one of three basically concentric rings: At the heart is the central city with its physical form given entirely (save in the newest metropolises such as Los Angeles and Houston) by nineteenth century scales and considerations. Surrounding that "city" are the suburbs extending outward as far as daily commuting by public transportation allowed. This is the city of the $1920^{\circ}$ s and 1930 's built up at fairly low densities but as a continuous mat of urban forms. Further toward the country is to be found the city of the 1950 's but particularly of the 1960 's, where urban forms are discontinuous and within which there is a self-conscious attempt to perpetuate a rural "image". This is mainly an artificial ruralism, maintained to satisfy the psychological desires of urban people seeking to live "in the country". It is with such a world that the famous Nesw Yorker Magazine particularly concerns itself, demonstrating how complex is the present definition of "urban". It has become basically urbane in culture more than urban in morphology. 
Unfortunately there is no accepted name for this outer ring of cities. If we call the 1920-40 band of continuous suburbanization the "suburb", then we need a different term for the discontinuous outer band. Perhaps we should call it a cenurb, because this is a form of such recency that it is largely missing throughout urban history. Only in odd moments and places in the past - is around Rome with its villae - were such urban people resident in the country by choice. And for them, as well as the aristocracy of England's Home Counties, this was bringing a detached urban life, and a special elite morpho$\operatorname{logy}$, into the country. In the American case these are people of urban economic support seeking consciously to take on the more vital parts of rural life and to live in housing as close in form to that of the country as possible.

One final question remains to be dealt with, that of the future of American metropolises. No certain answer is obvious but several reasonable predictions seem valid. The first concerns the form of the city. There is little question that the physically dispersive tendencies of the metropolis are likely to slow down, stop, and possibly be reversed. The American scale of energy consumption will change and under scarcer and more costly energy conditions reemphasis of the two inner bands seems most probable. In fact, the advantages of geographical concentration, of the truly metropolitan form, will increase so that from desires of personal freedom and economic advantage people are likely to seek metropolitan residence and employment.

Unfortunately during the last ten years American economic organization, along with that of most of the capitalist world, has experienced a radical transformation in the site of control. In simple terms the conglomerate corporation has become dominant in the United States and the multi-national corporation in the capitalist world. In both types of organization decisions as to the locale of economic activity are beyond the control of individuals or even specific metropolises. Production moves from one city to another, or one country to another, in terms of a depersonalized economic "rationality" that is truly frightening to contemplate. The disease is not that of capitalism alone; it can attach to any system that places economic "rationality" ahead of human concerns. State planning is no more immune to this sort of disregard for human welfare than is conglomerate capitalism. America was most fortunate during its first three centuries, particularly in those two between independence and very recent times, in being free of too much rationality. The strong belief that existed in geographical equality, in free entry into capital formation (from commerce, industrial activity and land speculation) and in the essentially fundamental role that cities play in true regional development and equality, made urban life democratic and gave the very real benefits of urban life and culture to a larger proportion of the national population than any other country has ever experienced. We must exercise extreme caution in guiding the future course of metropolitanism in America between the equally frowning Scilla of too "rational" state planning and the Charybdis of too "rational"- private enterprise. 


\section{CHANGES IN URBAN HIERARCHY WITH SPECIFIC RESPECT TO URBANIZING REGIONS IN HUNGARY}

By

PÁL BELUSZKY

1. This paper summarizes the changes in the hierarchy of Hungarian cities from the turn of the century to the present day with specific respect to the urbanizing-agglomerating regions of the country.

Contradictory tendencies have developed in the structural changes of Hungarian urban hierarchy.

A) One can witness the process of the concentration of urban functions and the visible decline of several basic centers and small cities. The most obvious evidence of this decline is the decrease in the number of public administration centers. In 1927 for example there were 160 administrative districts; in 1950: 139; and in 1970 there were only 95 such districts. This change had occurred in spite of the fact that a significant part of the organizing, directing and supervising of production and the establishment of service industries must take place within the framework of central public administration activities. Consequently the loss of an administrative role automatically minimizes the directive, supervising and supplying roles of the former centers and places them significantly lower in the hierarchical order.

The efficient operation of institutional networks demands the construction of larger units. This demand as well as the specialization of institutions act as an incentive for further concentration.

B) Parallel with the process of concentration, one can also observe the dispersal of centralized functions. For example: while in 1900, in the present territory of Hungary, there were hospitals operating in 29 localities, today they operate in 82 localities. In 1900, secondary schools operated in 58 localities; today they operate in 200 localities. In 1930, only in 14 settlements were there travel agencies, today they are in 60 cities. The desire to supply the population better encourages decentralizing tendencies today.

2. In order to examine the differences in the urban hierarchy we have reconstructed the hierarchy that existed in 1900, 1930, 1960 and 1970. The following methods were utilized in this reconstruction.

A) Hierarchical level was measured by a quantitative and qualitative combination of basic urban functions;

B) An empirical inventory method was utilized, based on the studies of J. E. Brush, M. Goossen and M. PALOMAKI. Urban institutions were ranked on the basis of hierarchical levels. The rank ordering was based on "dispersion values" that were established as a function of the number of settlements supplied with certain central institutions. The following formula was utilized: $d=\frac{t_{i}}{T}$, where 
$d=$ the dispersion value of central functions;

$t_{i}=$ the number of settlements having a given function;

$T=$ the total number of settlements examined.

C) The dispersion value made it possible to compare the hierarchical levels of various institutions and to examine the provision of various institutions at different levels of localities.

D) The order of the hierarchical level was established empirically.

3. In Hungary a six-level urban hierarchy seems to exist.

I. Budapest.

II. Regional centers. There are five large cities in Hungary outside Budapest. Their populations range between 150,000 and 200,000 . Their central functions affect several counties, the most characteristic being universities, clinics, retail firms, publishing of literary-artistic journals, state railway directorates, etc. The regional centers may be reached within two to three hours from Budapest. The difference levels between Budapest and the regional centers is extremely great.

III. County seat centers. There are 12 county seats. Their populations range between 30,000 and 80,000 . Their main functions are: theaters, archives, various tourist offices, special departments of hospitals, certain special stores; the institutions of public administration at the county level.

IV. Medium-sized cities. Their population range between 15,000 and 50,000. Their characteristics are widely different. Although they are fairly significant, they are not, of necessity, district centers. Their characteristic functions are: basic departments of hospitals, some specialized medical treatment centers, some special high schools, certain specialized stores and travel agencies.

V. District seats. Small urban localities of between 5,000 and 30,000. Aside from district seats of public administration, they possess the basic departments of specialized out-patient clinics, certain special high schools, furniture and book stores, etc. There are approximately 90 such district seats.

VI. Basic centers. Their number is approximately 150. Their characteristic functions are: high schools, specialized stores, markets, branches of the state savings bank, dental services, etc.

4. The urban hierarchies for the four periods under examination are depicted in Figures $1-4$. On the basis of these figures the following conclusions may be drawn.

A) The vertical structure of urban hierarchy has not changed significantly since the turn of the century. It is natural that some urban functions have decreased and their hierarchical values have been lessened as a result of dispersal. Several institutions that formerly fulfilled urban functions now exist at rural levels. These changes, however, do not mean the flattening of the "hierarchical pyramid", since additional specialized functions continually appear on the top of the hierarchical pyramid. The functional and settlement hierarchy is reproduced, contradicting the hypothesis that the urban hierarchy's vertical structure is becoming simplified.

B) The number of urban functions has increased. The volume of contact between the city and the village has grown.

C) There is no proof that the above tendency will be altered in the future; at the most the tempo of creating further ties will lessen. The contacts will, 


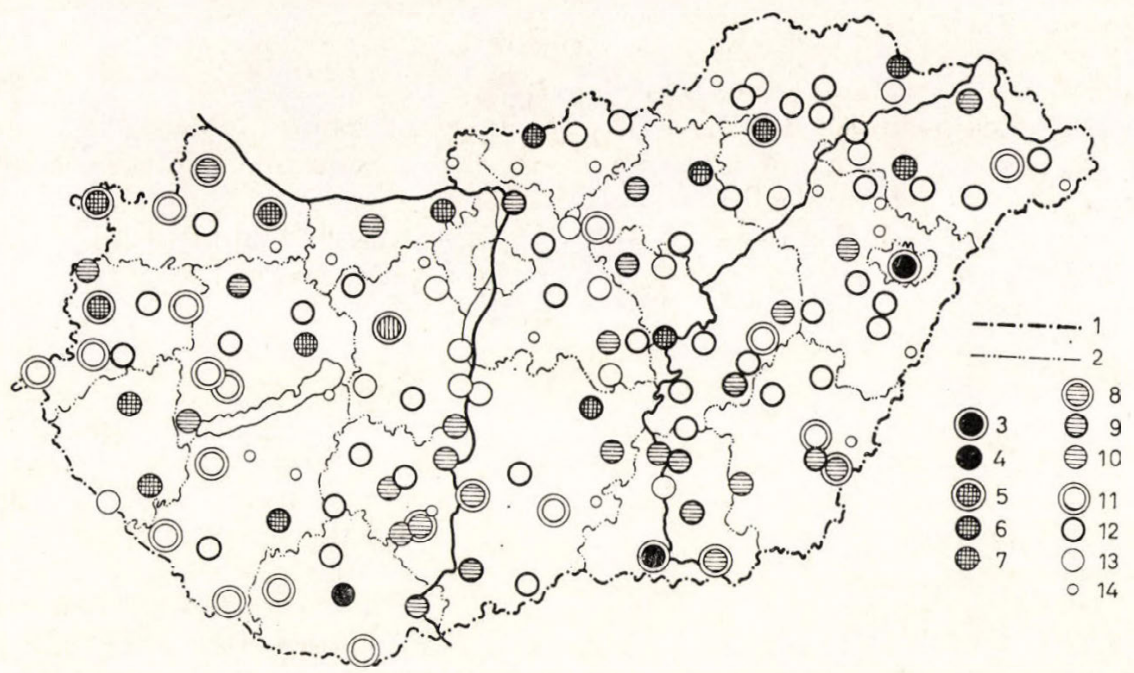

Fig. 1. Hierarchy of Hungarian towns in 1900

$1=$ state boundary (in 1970) $; 2=$ county boundary (in 1970); $3=$ macro-regional centers; $4=$ macro-regional centers with incomplete functions; $5=$ county seats with certain macroregional functions; $6=$ county seats $; 7=$ county seats with incomplete functions; $8=$ middle towns with certain county seat functions; $9=$ middle towns; $10=$ middle towns with incomplete functions; $11=$ district centers with certain middle town functions; $12=$ district centers; $13=$ district centers with incomplete functions; $14=$ elementary centers

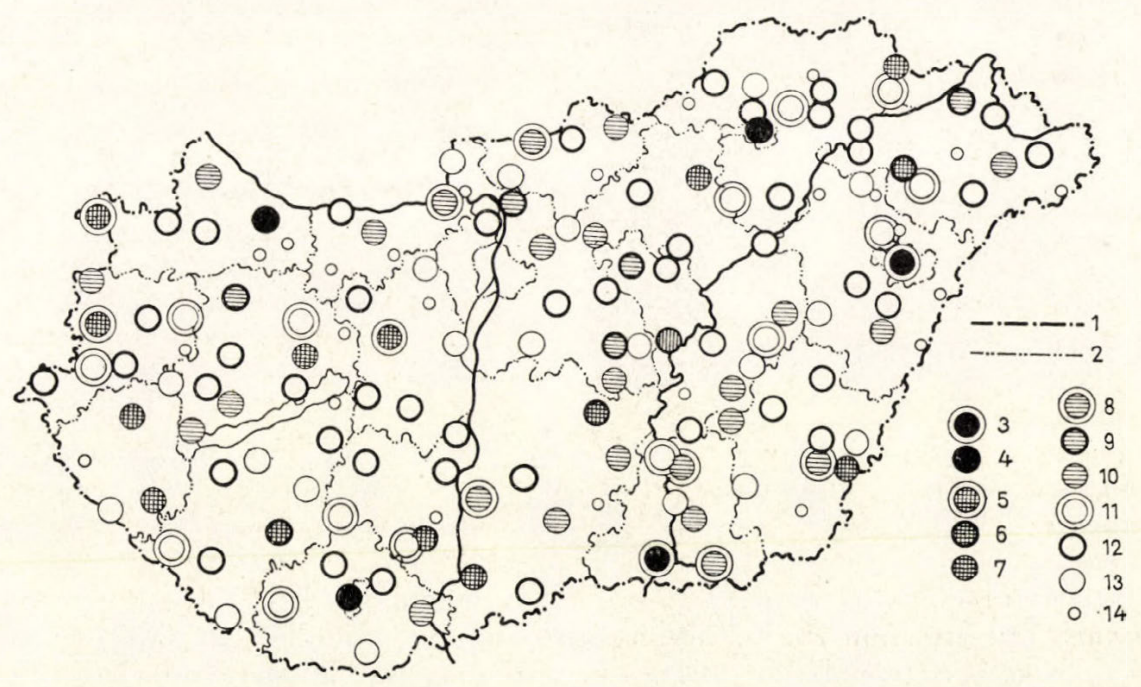

Fig. 2. Hierarchy of Hungarian towns in 1930 (See legend of Fig. 1.) 


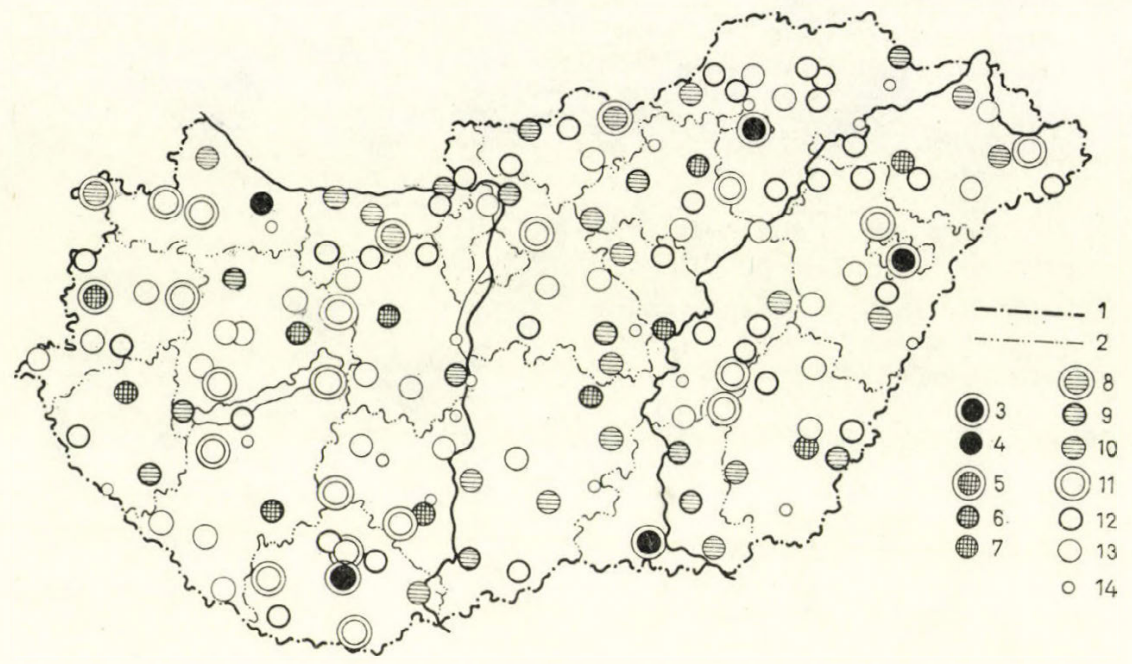

Fig. 3. Hierarchy of Hungarian towns in 1960 (See legend of Fig. 1.)

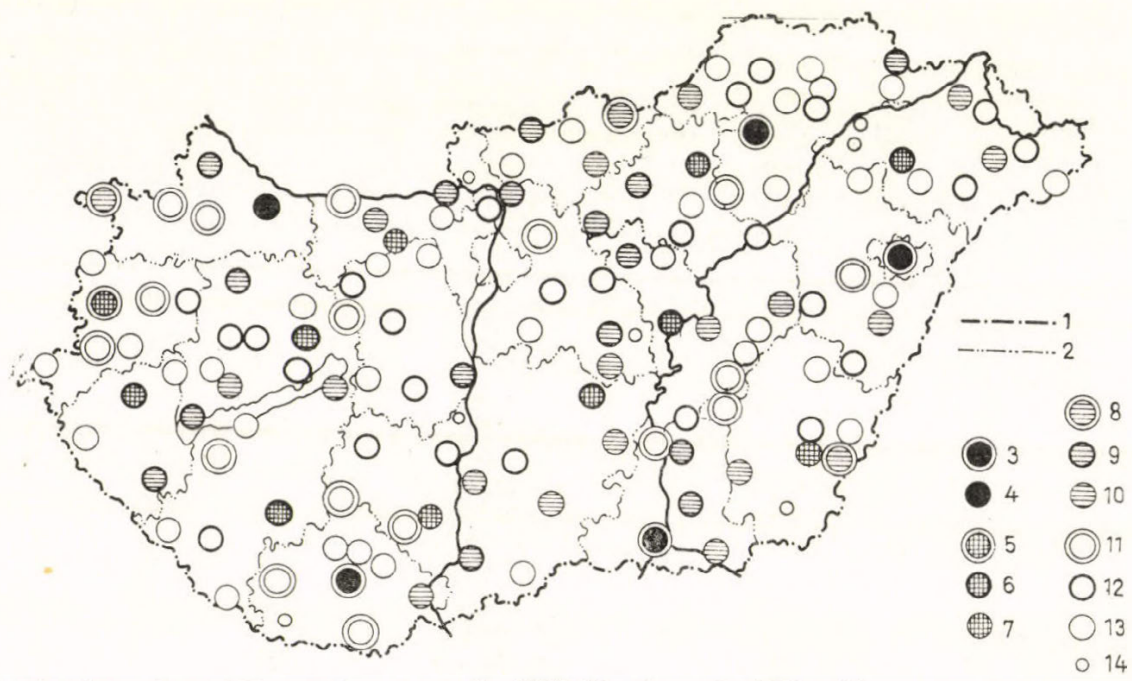

Fig. 4. Hierarchy of Hungarian towns in 1970 (See legend of Fig. 1.)

at the same time exist at several levels. There is no proof supporting the hypothesis that the downward flow of urban functions and improvement in the rural supply functions leads to a weakening of ties between urban and rural communities.

D) Urban retail functions will also continue to grow. In 190062 per cent, in 196073 per cent, in 197070 per cent of those who made a living from commercial activities lived in cities. The development of small-scale retail activities tends in the same direction, although we have data available dealing with 
this aspect only since 1957. In 195774.8 per cent, in $197177 \cdot 2$ per cent of small retail trade activities took place in cities which belong to categories $I-I V$. The fact that the total number of people living in urban environments has grown significantly, has also played a part in the concentration of these activities.

E) The demands for urban services continue to increase in two respects:

I. The rural population tends to increase its demands for services by visiting centers where higher level services can be rendered;

II. Generally, more frequent visits are paid to the various centers.

This dual aspect of demand affects the various hierarchical orders differently.

1. The demand for higher levels of services increases the importance of the higher level centers.

2. The demand for urban services increases the importance of nearby centers as well, regardless of the lower levels of functional specialization.

F) The demand for the urban places as service centers, therefore, continues to increase. Today services of an urban character are rendered approximately by the same number of urban settlements as in 1900, in spite of the fact, that the number of city centers grew until 1919 and decreased somewhat eversince. There are approximately the same number of settlements in each category as there were in 1900.

Although the structure of the settlement hierarchy has been extremely stable, the fates of individual centers have been very different. The hierarchical rank of 40 per cent of the cities have been altered since the turn of the century. Several settlements that were small towns 80 or 100 years ago, are now only basic centers or villages without central functions.

At the same time, new settlements with urban functions have become parts of the urban network or have increased their urban functions significantly.

In districts where industrialization has taken place in a more emphatic manner, the hierarchical levels of centers have been altered in different ways. The areas dense in population based on the industries of certain regions, have acquired urban functions and have taken over urban roles from traditional urban centers. Although this process had begun prior to World War II, it has been given increased impetus during the last decades. Added to this tendency has the conscious desire to develop the industrial settlements into settlements that are capable of satisfying urban demands. Tatabánya and Salgótarján, two such industrial centers, became county seats in 1950. Industrial concentrations that have been built up since World War II, the so-called socialist towns, have acquired urban rank and among them some have acquired in addition the role of the small city that attracts the populations of neighbouring areas. Among the latter the most notable are: Komló, Várpalota, Dunaújváros, Ajka, Oroszlány, Kazincbarcika, Leninváros.

Several basic centers also developed in the economically active zone of agglomeration. The side-by-side existence of new basic centers, traditional, old centers, and the sharply rising industrial cities create a city-network whose functions are more complicated than in the traditional urban-rural relationship.

In spite of these factors, urbanization hitherto has achieved superficial effects; fundamental changes have not yet been accomplished. The reason 
for the lack of fundamental change is primarily the brief historical span of these processes and the limited nature of true urban agglomeration. Although the occupational structure of the rural population has been broadened significantly, and has become more "urbanized", this has not yet been followed up by the creation of a more dynamic social structure and by an alteration of the functions and morphology of the settlements. Consequently, aside from selected agglomeration cores, broad "preurbanized" zones have developed as well.

The development of urban networks and the central role of the towns have been defined largely by the central decisions of the state apparatus; the influence of the public administrative rank of the location is visible in these decisions. The development of socialist relations of production has also left a sharp, decisive mark on the development of the urban network in the following respects:

A. The planned socio-economic life of the state, its direction, supervision and institutional frameworks, have increased the role of the centers of public administration.

B. Planned urban development, the wide distribution of the products manufactured in the cities, have limited "spontaneous" urban development and restricted the role of the "classical urban development energies".

C. The organization of economic life has been handled more and more as an administrative matter and the number of personal "business" trips of the population has been on the decline.

D. The role of the cities as service centers has been increased extremely rapidly.

E. Industrialization has played a direct role in general urban development, and an indirect role in the development of central functions.

The concentration of central functions in the centers of public administration has been the most dynamic activity. The role of the district and countyseats has increased, the regional centers have maintained their former level of development and importance and the middle sized cities have lost some of their previous importance.

There is an extremely large gap between Budapest and the regional centers in (a) the weight of their economic role; (b) in the level of fulfilled urban function and (c) in the volume of organized urban functions. In the development of this phenomenon, significant roles were played by the small territory of the country the central location of the capital, the latter's economic preponderance and the historical evolution of the capital city. Before the World War I regional centers are all outside the present borders of the country (Pozsony, Kolozsvár, Temesvár, Zágráb, partially Kassa and Nagyvárad). In the present territory of the country only Debrecen and Szeged fulfilled characteristic functions of regional centers. For this reason, between the two World Wars the development of cities at this hierarchical level was important. Miskolc and Győr entered the ranks of regional centers during these years. In the three decades since the end of World War II their roles have become even more multifaced, the volume of their urban functions have increased, the tempo of their population growth has been satisfactory. Even so, their position in the urban network has hardly been altered; in fact they have moved closer to the roles played by county-seats and farther away from the capital. 
New functions that are qualitatively different from those of the capital have hardly been adopted by the regional centers. It seems that the inner dynamics and opportunities of these cities themselves, are not adequate for the kind of development that would propel these cities to become counterpoles to Budapest and to fulfil the roles demanded of them in this type of development pattern. It can be expected, however, that eventually high level functions will start to move from Budapest toward the rural areas. It is an important task to concentrate these functions in the regional centers.

All those functions that have been characteristic of the early phase of socialist urban development, were favourable for the growth of the roles of the county-seats.

A. The increase in the importance of public administration functions, naturally, had increased the importance of county-seats. A significant transformation of the public functions from the regional centers to the countyseats has begun. This process has not been restricted to legal functions, but has extended to several service, health, education and commercial functions as well.

B. The institutionalization of the central role of the county-seats has occurred at the expense of the middle sized cities and of lower order centers. The institutionalization of health, education, commercial and cultural functions allowed the county-seats to play favored roles outside public administrative functions. Unlike prior to World War II when many county-seats had important roles to play only because of their public administrative functions, today they have taken away even the economic-distributive functions from the regional centers and are the pervasive forces throughout the entire county. While previously the smaller centers acted side-by-side with the countyseats, today they are subordinated to them.

The county-seats have enjoyed preferential treatment since the 1950's. The reason for this preferential treatment are:

A. The industrialization of the countryside has extended to the level of the county-seats since the 1950's.

B. The county-seats had to fulfil greater demands. Therefore investment was concentrated at these places at the expense of the smaller cities.

C. With regard to the level of investment, the regional centers were not treated preferentially.

Consequently, the most visible process in the alteration of the urban hierarchy has been the significant increase in the role fulfilled by the county-seats during the last three decades. The central role of these centers has developed approximately the same way since 1949, although the tempo of that growth has varied from place to place.

In our research design special attention has been paid to the small towns. The reasons for our special attention were:

A. The supply of the population with "urban services" has been accomplished to the greatest extent by the fifth order centers.

B. The "front-lines" of the concentration and dispersal of urban functions at the present time are located within the ranks of the fifth order and these centers are affected by every change in the movement of these "front-lines".

C. Through entrance into this rank a settlement becomes a city. 
D. In countries with high technical levels of civilization the growth in demand attacks the very existence of the small towns and some authors doubt the possibility of their continued existence.

The post-war growth of the small towns can be divided into two periods. The first period lasted through the 1950's. During this time the increased importance of the public administrative functions and the institutionalization of central administration increased the urban functions of this hierarchical level since their central roles stem specifically from these public administration functions. During these years in the various functional groups downward movement of functions had already reached the centers of the fifth order and resulted in such activities as the urbanization of high schools, the establishment of banks, financial and insurance services. Finally the growth in the importance of public administration functions weakened the situation of the basic centers and this resulted in the transformation of some institutions and functions from the latter to the former.

On the other hand, industrialization has not yet affected the fifth order centers. During these years their infrastructural development was limited and the so-called communal investments were restricted. There were hardly any apartment constructions by the state. In several categories of functions the of urban institutions has not yet reached this level. Specifically neglected wave areas were health, tourism and services. During the period of 1949-1960 the growth of the population of these small towns was only 12.6 per cent. If we exclude the growth of the so-called socialist towns from this category the real growth of the entire level is merely $6 \cdot 2$ per cent. The number of these centers decreased somewhat between 1930 and 1960, in spite of the entrance of some new towns into this category. This decrease in the number of small towns is largely due to the decline of several district centers that were unable to fulfil necessary urban functions.

In the 1960's there began an increased differentiation within the ranks of the fifth order. Between 1960 and 197232 settlements lost the rank of district seats. At the same time, those centers which were able to keep their public administrative functions grew in size and in importance. Industrialization reached these centers by the middle of the 1960's. The downward current of urban functions was also significant. Health institutions, service institutions were built, while the level of retail trade grew. Somewhat slowly even their infrastructural development began. Their role increased also due to the fact that among the population, specifically during the 1960 's, the demand for urban services;became stronger. As a result of all these factors the relative weight of fifth order centers within the urban network has increased significantly. They are now on the way to becoming small cities with variegated urban functions which are able to maintain close ties with their surroundings. Among them several have even acquired the legal status of town.

In conclusion, we can observe that the so-called middle sized cities have lost some of their functions in supplying the population with "urban goods". We may further observe that the horizontal and vertical structure of the urban hierarchy has not been significantly altered since the turn of the century in Hungary, in spite of the greater differentiation between the various hierarchical levels. 
A

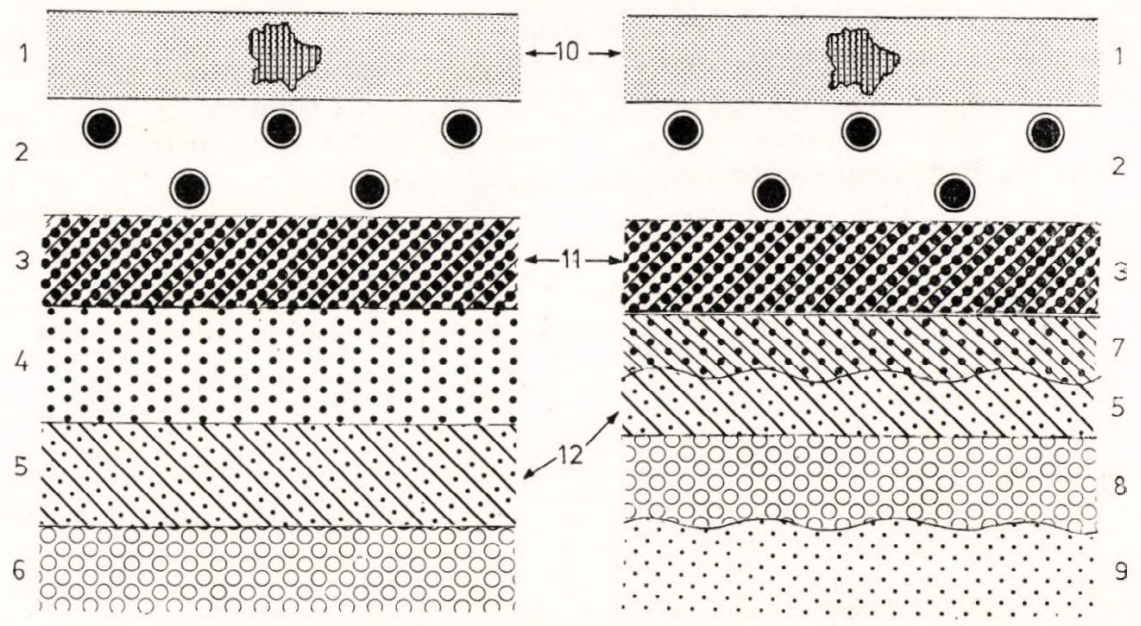

Fig. 5. Perspective trend in the vertical structure of the urban hierarchy

$\mathrm{A}=$ the present state; $\mathrm{B}=$ structure to be expected in the near future; $1=$ capital; $2=$ regional centers; $3=$ county seats; $4=$ middle towns; $5=$ towns of district seat level; $6=$ elementary centers; $7=$ developed towns of district seat level; $8=$ first-rate elementary centers; $9=$ second-rate elementary centers; $10=$ functions of national level; $11=$ functions of county level: $12=$ functions of district level

At the same time, however, the beginnings of restratification can be observed. In contrast with the presentvertical structure (Figure 5, A) change can be expected in the lower levels. As a result of the decreasing number of district seats and of the development of those retaining this function the differences between fourth and fifth order centers will become less pronounced. Due to the variegated size of the population, the historical past, the population number that must be served and the occupied positions within the settlement network we cannot expect a complete levelling within each category. Consequently, it seems that there is a necessity for further differentiation between the fourth and fifth order. It can be expected that two or three different kinds of basic centers will develop below this level (Figure 5, B). 



\section{IMPACTS OF URBAN GROWTH CENTERS ON THEIR HINTERLANDS}

By

RICHARD L. MORRILL

\section{INTRODUCTION}

In an earlier paper ${ }^{1}$ I proposed a number of hypothetical relations detailing the impacts of a growing urban center on its hinterland. Much of the justification for concentration of investment in growth centers as a tool for regional development rests on the geographic spread of economic and social benefits to the surrounding hinterlands. These benefits or effects are supposed to include at least: (1) effects on regional farmers; (2) income transfers from recreation etc.; (3) income transfers from commutation; (4) possible industrial spillower; (5) income loss effects beyond the commuter zone; and (6) environmental impacts.

The benefits arise, it is hoped, partly because the center can absorb the surplus labor of a region into reasonably remunerative employment. The nature and magnitude of impacts may be expected to depend, too, on the severity of economic and demographic conditions in the hinterlands, the quality of transportation and the structure of private and public investment.

The proper measurement of these effects and their evaluation requires data on the magnitude and location of individual, enterprise and governmental expenditures, and an understanding of micro-geographic flows of funds. Such analysis has not proved feasible, so the present paper reports only on more aggregate and indirect consequences - namely changes in the levels of population, commutation and various characteristics of populations in several sample commuter hinterlands. Limited data on local school district expenditures permit some additional insight on the impact of hinterland population change on costs of providing public services.

Important recent work has been done on environmental impacts, particularly the loss of quality agricultural land to urban, industrial and speculative use in the closer urban hinterlands. In this paper only some limited evidence for the Seattle, Washington (USA) area will be presented.

\section{THEORETICAL EXPECTATIONS AND HYPOTHESES}

\section{EFFECTS ON LOCAL AGRICULTURE}

Of the many possible effects, including change in production, markets and supplies, only two indices will be measured here: first, the change in acreage and intensity (loss of farmlands near the city versus possible increases farther

1 Morrill, R. L.: Grospth Center-Hinterland Relations. IGU Symp. on Transmission of Regional Growth, London, Ontario, 1972. 
away); and second, change in income from farming or land value (relative to similar areas not close to a growing urban center).

\section{INCOME TRANSFERS FROM DIRECT PURCHASE OF HINTERLAND GOODS AND SERVICES BY CITY RESIDENTS}

In the earlier paper, (see footnote 1), these expenditures (for goods and services like produce, recreation fees, gasoline, food, and for rent and/or purchase of property like second homes) were predicted to follow a gravitational form, for example:

$$
\text { (1) } \$ \text { expenditure }+\$ a \frac{\text { City population }}{\text { Distance }^{b}}\left(\begin{array}{c}
\text { Destination } \\
\text { attractiveness }
\end{array}\right)
$$

where $\$$ is a maximum per capita expenditure.

No comprehensive survey will be given of the probably hundreds of surveys and studies, most of which do not permit measuring the above relationship. However, some indicative results from expenditure studies will be reported, and some data can be analyzed for possible welfare effects in local areas dependent on these expenditures.

\section{INCOME TRANSFERS FROM COMMUTING}

In the earlier paper, mentioned in footnote 1, a series of relations were outlined, which were expected to result in net benefits in the active commuter zone, as a consequence of income transfers via expenditures on land and housing; retail and service activities, and tax payments. It was hypothesized that the portion of the commuter's family income spent in the area of residence versus the central city increases directly with distance, although the aggregate expenditures of all commuters per unit area probably falls with distance. Within the main commuter zone, not only population but also the per capita level of income and the level and quality of goods and services should rise.

The proportion of the population commuting was suggested to follow the simple interaction relation:

$$
(2)^{\star} \text { Per cent commuting }=a \frac{\text { Population }^{c}}{\text { Distance }^{b}} \text { (of destination) }
$$

The effect of increasing population is suggested to increase the intensity of commuting in closer areas more than to extend the range of commutation. Thus the distance at which economically critical proportions of the labor

* In looking at a system of cities the expression:

$$
\text { (2a) } \% \text { commuting }=a \frac{\text { Population }}{\text { Distance }^{b}}\left[\frac{\bar{D}}{\text { Density }}\right]^{c}
$$

where $c$ is less than one is preferred. The modifying expression, where $D$ is a mean national density of urban hinterlands, has the effect of increasing the proportion commuting at a given distance as density falls. 
force commute to the city does shift outward significantly, as size of city increases.

Data are available to test this relation, although, in the United States data used, destinations are reported very crudely. However, interest centers in how the extent of the commuter field changes over the decade 1960-1970, and whether the degree of change in the proportion commuting, and the actual proportion commuting, are related to the relative amount and rate of growth of different cities. We want to test the hypothesis that faster and greater growth led to greater increases in commuting, that is to greater spread of population growth out of the city itself.

With respect to income transfers, a relation of the following form is suggested:

$\underset{\text { (per sq. mile) }}{\$ \text { expenditure }}=\$ k\left(a \frac{\text { Population }}{\text { Distance }^{b}}\right) \quad\left(\frac{\text { Distance }}{k}\right)$

where $\$ k$ are total family expenditures: $\left(\frac{\text { Distance }}{k}\right)$ is an expression indicating that the proportion of income spent locally in the area of residence increases with distance from the city; and $\left(a \frac{\text { Population }}{\text { Distance }^{b}}\right)$

estimates the number of commuters from that area.

No data are available to estimate the equation directly. Rather, it is necessary to be content for now with crude estimates of the relative and absolute change in income for areas in the commuter zone. We can measure change in aggregate income, and also compare the change in per capita and/or median family income relative to change in the city and in areas well beyond the commuter zone. We hypothesize a greater than average improvement in income, at least in those parts of the hinterland for which the proportion commuting increased most rapidly.

One of the less desirable impacts of increased commuting may be the disruption of social and other services. In particular, the commuting population tends to be fairly young, with many children. This places severe pressures on local school capacity; and the fact that industry and commerce tend to lag behind residential development places high financial burdens on the population in these areas.

In the earlier article (see footnote 1), I also argued that the severity of conditions in the hinterland would make a difference, especially in the ability of the growing center to bring its hinterland to acceptable levels of welfare. ${ }^{2}$ Again only very crude measures are attempted: namely comparison in the relative and absolute dollar improvement in income in areas with comparable proportions commuting, for originally richer and poorer hinterlands. It is perhaps reasonable to hypothesize that relative improvement will be greater in the poorer hinterlands, but that the absolute improvement may be greater in the richer.

${ }^{2}$ Hansen, N. M. in D. L. McKee et al. (eds): Regional Economics. New York, The Free Press, 1970, pp. 121-136, 229-241. 


\section{EFFECTS BEYOND THE COMMUTER ZONE}

Beyond the commuter zone, it has been hypothesized that absolute or relative decline (out-migration) in population is likely to occur, and perhaps relative decline (less than proportional improvement) in income as well, as a result of migration of the more talented younger population to the city. ${ }^{3}$ This can be tested, at least indirectly, via measuring change in population and income in these zones. We particularly want to measure the distance (or critical proportion of the population commuting) at which net benefits change to net losses, if they do, since this has vital implications for policy on designation and investment in growth centers.

To summarize the objectives of this initial study, it is intended to

1. measure change in land devoted to farming, and

2. measure change in income from farming in commuter hinterlands;

3. report on studies of income transfers from recreation;

4. report on some effects of tourism-related growth on a local economy;

5. calibrate the proportion commuting with distance and measure change in the number and proportion commuting relative to growth of the city;

6. measure change in per capita and aggregate income in the commuter hinterland relative to the city and to areas beyond the hinterland;

7. report on relative costs of providing school services in areas of the commuter hinterland;

8. compare change in relative and absolute income for richer and poorer hinterlands; and

9. measure whether (and at what distance) benefits from commuting (etc.) give way to losses (out-migration, relative income decline).

\section{DATA}

To examine the above questions, both census and locally generated data are used. With respect to questions 1 and 2 (agriculture impacts), example data are reported for the Seattle and Tacoma metropolitan areas (Washington State, U.S.A.).Questions 3 and 4 (tourist expenditure impacts) are investigated through data on expenditures in and around National Parks in Washington State, and through related data for Oregon; and through data on county tax rates (San Juan County, Washington, U.S.A.). Questions 5, 6 and 9 (commuting impacts) are analyzed for a sample of up to 17 metropolitan areas, varying in size, rates of growth, income level, and regional setting (Table I). As appropriate or available, data are analyzed for counties, minor civil division, and census tracts, in order of finer units. (U. S. Census of Population 1960, 1970. Social and Economic Characteristics.) Question 7 (school costs) is analyzed through Seattle metropolitan area data, and Question 8 (richer versus poorer areas) involves a comparison between Seattle and Atlanta.

${ }^{3}$ Myrdal, G.: Rich Lands and Poor. New York, Harper,1957. 


\section{TABLE I}

Sample cities

\begin{tabular}{l|l|l|l}
\hline & \multicolumn{1}{|c|}{ Large } & \multicolumn{1}{c}{ Medium } & \multicolumn{1}{c}{ Small } \\
\hline \multirow{3}{*}{ Fast } & $\begin{array}{l}\text { Atlanta } \\
\text { Seattle }\end{array}$ & $\begin{array}{l}\text { Orlando, Fla. } \\
\text { Colorado Spr. }\end{array}$ & Huntsville, Ala. \\
Slow & $\begin{array}{l}\text { Grand Rapids } \\
\text { Omaha }\end{array}$ & $\begin{array}{l}\text { Ft. Wayne, Ind. } \\
\text { York, Penn. }\end{array}$ & $\begin{array}{l}\text { Billings, Mont. } \\
\text { Ft. Smith, Ark. } \\
\text { Birmingham } \\
\text { Toledo, Ohio }\end{array}$ \\
& $\begin{array}{l}\text { Pueblo, Colo. } \\
\text { Des Moines }\end{array}$ & Gadsen, Ala. \\
& Fresno, Ca. &
\end{tabular}

\section{FINDINGS}

\section{IMPACTS OF URBAN GROWTH ON HINTERLAND AGRICULTURE}

While the growth of a very large metropolitan market is bound to have great developmental effects on quite a wide hinterland, we are concerned here with effects in the commuter zone. In an earlier era, one might have expected to find an intense market-gardening zone around the city, and this was true of Seattle before 1950. However, the increase in family income and mobility bestowed by the car created tremendous speculative pressures on these farmlands. The effects of urban encroachment on agriculture, even in so short a period as the five years, 1964 to 1969, is well illustrated through data for King and Pierce counties (Seattle and Tacoma, Washington, with about 1,000,000 and 350,000 people respectively). (U. S. Census of Agriculture 1964, 1969.)

While the number of farms declined by 25 per cent across the state they dropped by 34 and 41 per cent in the growing metropolitan King and Pierce counties. Farm acreage dropped by 26 and 45 per cent in only five years in the two urban counties, compared to only 8 per cent statewide. The losses in the urban fringe in the two counties amounted to 125 square miles (323 sq. km). During this period, Tacoma's growth was directed more to good farmland than was Seattle's, where the damage was greater in the previous five to ten years (Table II).

While farm size was increasing markedly in the state (418 to 516 acres or 168 to 207 hectares), average size was stable or decreasing in the urban counties.

A similar pattern occurred with respect to the class $1-5$ farms, which generated more than $\$ 2500$ in value of production in 1969 . The value of land and farm buildings per farm and per acre rose preciously (140 per cent) in Pierce County, where urban pressure on farmland was most intense. The value per acre in these two counties is by far the highest in the state, seven to nine times the state average, levels at which local taxes on property become severe, and an incentive to sell off farms to urban land developers. 


\section{TABLE II}

Farmland change in metropolitan Seattle-Tacoma

\begin{tabular}{|c|c|c|c|}
\hline Category & $\begin{array}{l}\text { King County } \\
\text { (Seattle) }\end{array}$ & Pierce (Tacoma) & Washington State \\
\hline $\begin{array}{l}\text { No. of farms, } 1969 \\
\text { No. of farms, } 1964\end{array}$ & $\begin{array}{l}1212 \\
1825\end{array}$ & $\begin{array}{l}1209 \\
2054\end{array}$ & $\begin{array}{l}34,003 \\
45,574\end{array}$ \\
\hline$\%$ change & -34 & -41 & -25 \\
\hline $\begin{array}{l}\text { Acreage } 1969 \\
\text { Acreage } 1964\end{array}$ & $\begin{array}{l}61,107 \\
82,355\end{array}$ & $\begin{array}{r}73,163 \\
132,245\end{array}$ & $\begin{array}{l}17,559,187 \\
19,052,500\end{array}$ \\
\hline$\%$ change & -26 & -45 & -8 \\
\hline $\begin{array}{l}\text { Average size, } 1969 \text { (acres) } \\
\text { Average size, } 1964 \text { (acres) }\end{array}$ & $\begin{array}{l}50 \cdot 4 \\
45 \cdot 1\end{array}$ & $\begin{array}{l}60 \cdot 5 \\
64 \cdot 4\end{array}$ & $\begin{array}{l}515 \cdot 9 \\
418\end{array}$ \\
\hline Change in size & $4 \cdot 7$ & $-3 \cdot 9$ & +98 \\
\hline \multicolumn{4}{|l|}{ Class 1-5 farms } \\
\hline $\begin{array}{l}\text { No. of farms, } 1969 \\
\text { No. of farms, } 1964\end{array}$ & $\begin{array}{l}574 \\
720\end{array}$ & $\begin{array}{l}623 \\
699\end{array}$ & $\begin{array}{l}21,788 \\
22,431\end{array}$ \\
\hline$\%$ change & -20 & $-9 \cdot 5$ & -3 \\
\hline $\begin{array}{l}\text { Acreage, } 1969 \\
\text { Acreage, } 1964\end{array}$ & $\begin{array}{l}39,365 \\
49,914\end{array}$ & $\begin{array}{l}48,975 \\
72,523\end{array}$ & $\begin{array}{l}14,568,000 \\
15,961,000\end{array}$ \\
\hline$\%$ change & -21 & -33 & -9 \\
\hline $\begin{array}{lr}\text { Value buildings, land } \\
\text { per farm, } & 1969 \\
\text { Value buildings, } & 1964\end{array}$ & $\begin{array}{r}\$ 104,278 \\
64,949\end{array}$ & $\begin{array}{r}\$ 80,610 \\
35,912\end{array}$ & $\begin{array}{r}\$ 115,487 \\
64,300\end{array}$ \\
\hline$\%$ change & +61 & +140 & +83 \\
\hline $\begin{array}{l}\text { Value per acre, } 1969 \\
\text { Value per acre, } 1964\end{array}$ & $\begin{array}{r}\$ 2,068 \\
1,407\end{array}$ & $\begin{array}{r}\$ 1,332 \\
560\end{array}$ & $\begin{array}{l}224 \\
154\end{array}$ \\
\hline$\%$ change & +47 & +138 & +45 \\
\hline
\end{tabular}

\section{IMPACT OF TOURIST EXPENDITURES ON A CITY HINTERLAND}

A study of the impact of visits to Mount Rainier and Olympic National Parks in Washington State is illustrative. ${ }^{4}$ These are exotic parks of national importance, yet most of the visitation is in fact of local metropolitan origin, the Seattle and Tacoma urban areas. Around most metropolitan areas, the distribution of tourist visits will similarly tend to concentrate on a few favored places. Here about 70 per cent of trips were of local origins. The probability of a metropolitan resident visiting the park was 0.5 (or 600,000 trips !) while

4 Beyers, W. B.: An Economic Impact Study of Mt. Rainier and Olympic National Parks. Prepared for the National Park Service. Seattle, University of Washington, Department of Geography, February 1970.

Beyers, W. B.: An Economic Impact Study of the North Cascades National Park and Ross Lake and Lake Chelan National Recreation Areas. Prepared for the National Park Service. Seattle, University of Washington, Department of Geography, May 1970. 
already in the neighboring states, the probability drops to 0.01 or below, a beautiful example of the principles of interaction and intervening opportunities. Tourist trips tend to be concentrated in time as well, with over 70 per cent of the 70 per cent, or over half of all trips being summer trips by local urban residents. Obviously this affects the generation of income to residents of the tourist-impacted areas around the parks.

A particularly significant finding is that the majority of expenditures in the immediate hinterland are in the metropolitan center, before or after the trips. Visitor expenditures were about $\$ 10$ per capita; but two-thirds of this was spent in the urban area before or after the trip, and about $1 / 4$ (\$2 to $\$ 3$ ) in or near the parks. The expenditures were predominantly auto, food and giftrelated, that is in the local service and retail sectors.

The annual expenditures of the urban residents in the park vicinity then are about $\$ 1$ to $\$ 2$ million. This is not going to support more than perhaps 1000 people directly, or supply more than about 10 per cent of the aggregate income of the about 10,000 people in the immediate region of the parks.

A study of tourism's impact in Oregon ${ }^{5}$ indicated that in the rural hinterlands of metropolitan counties (Portland, Eugene, Salem) perhaps 5 to 10 per cent of local income is provided by tourism. Moreover, this study points out that this income is not "net" - that is, public and private costs were associated with providing tourist services - for example, roads and their maintenance, law enforcement, land acquisition, facility construction etc.; so the net benefits from tourism in the hinterland economy may well be slight. Tourist-related jobs are also shown to provide incomes of only about 55 to 60 per cent of the state average.

San Juan County, Washington, is a small county consisting of islands, and is perhaps the most dependent on or impacted by tourist expenditures. That tourists require costly services, much of which cost must be borne by local residents and property owners is indicated by the fact that the county has by far the highest per capita property taxes in the state, \$430 in 1973 (rompared to the state average of $\$ 205)$.

\section{COSTS OF PROVIDING SCHOOL SERVICES IN COMMUTER HINTERLANDS}

In the United States, local school districts are typically responsible for raising much of the resources needed to cover costs of public education. King County, Washington, provides a fairly typical example of the differential ability of local districts to raise money and support their schools.

In general the suburban areas have the highest proportions of children and ratios of children to assessed valuation. As a consequence their levies are very much higher than in the central city (Seattle in this case), and certain industrial suburbs (the "South Central"' district), with much commerce and industry. In exurban areas (the outer commuter zone), the assessed valuation

${ }^{5}$ Economic Analysis of Resource Allocation in the Oregon State Highway Division: Tourism. Department of Economics, Oregon State University, Salem, Oregon, 1972. 
per pupil varies from poor (Federal Way, Northshore, Issaquah, Tahoma) to rather good (Snoqualmie Valley with rich forest lands) but the nature of the population (lower income and education) changes, and is less willing to support education at quality levels. Highest levies are (or would be, if supported) in the least dense suburban-exurban areas, with fairly young, middle income populations, with rather high proportions of children, but without adequate employment bases. These discrepancies clearly diminish the real incomes, as well as the quality of education, of residents in these zones.

To illustrate, the 1973-1974 education levies per \$1000 assessed valuation was $\$ 8.75$ in Seattle, which provided a very high $\$ 812$ per pupil, and could support all kinds of special programs, whereas it was $\$ 17.25$ in Federal Way (providing but $\$ 480$ per pupil), only $\$ 6.41$ in the rich South Central District, but $\$ 11.38$ in Issaquah, providing $\$ 520$ per pupil; $\$ 12.28$ in Shoreline $(\$ 470$ per pupil); $\$ 8.70$ in Tahoma (only $\$ 265$ per pupil, and the levy was $\$ 24$ in $1972-1973) ; \$ 9.35$ in Lake Washington, for $\$ 410$ per pupil; $\$ 11.67$ in Northshore for $\$ 440$ per pupil. The central city with its high tax base has a significant advantage over the suburban commuter fringe.

Provision of fire, law enforcement, transport, road maintenance, and other services have a similar adverse balance.

\section{SOME MEASURES AND IMPACTS OF COMMUTING}

The relations between commuting, population growth and income are analyzed statistically, graphically and through maps, utilizing a sample of seventeen United States cities and hinterlands, varying in size, rate of growth and by region.

With respect to the current (1970) state, we are interested in:

1. the decline of commuting over distance, and the role of population size and region,

2. the possible relation between commuting and income, and the role of population size and region,

3. change in this relation between commuting and income with distance. in:

With respect to change, measured between 1960 and 1970 , we are interested

4. the relation between proportional change (increase) in median income and the proportion commuting, and change in the proportion commuting, again taking into account distance and population size,

5 . the relation between absolute change in median income and the same variables,

6 . the relation between rate of population change and the proportion commuting, change in the proportion commuting, and other variables,

7. the relation between net migration, and the same variables, and

8 . the relation between change in the proportion commuting, distance, increase in income and other variables. 


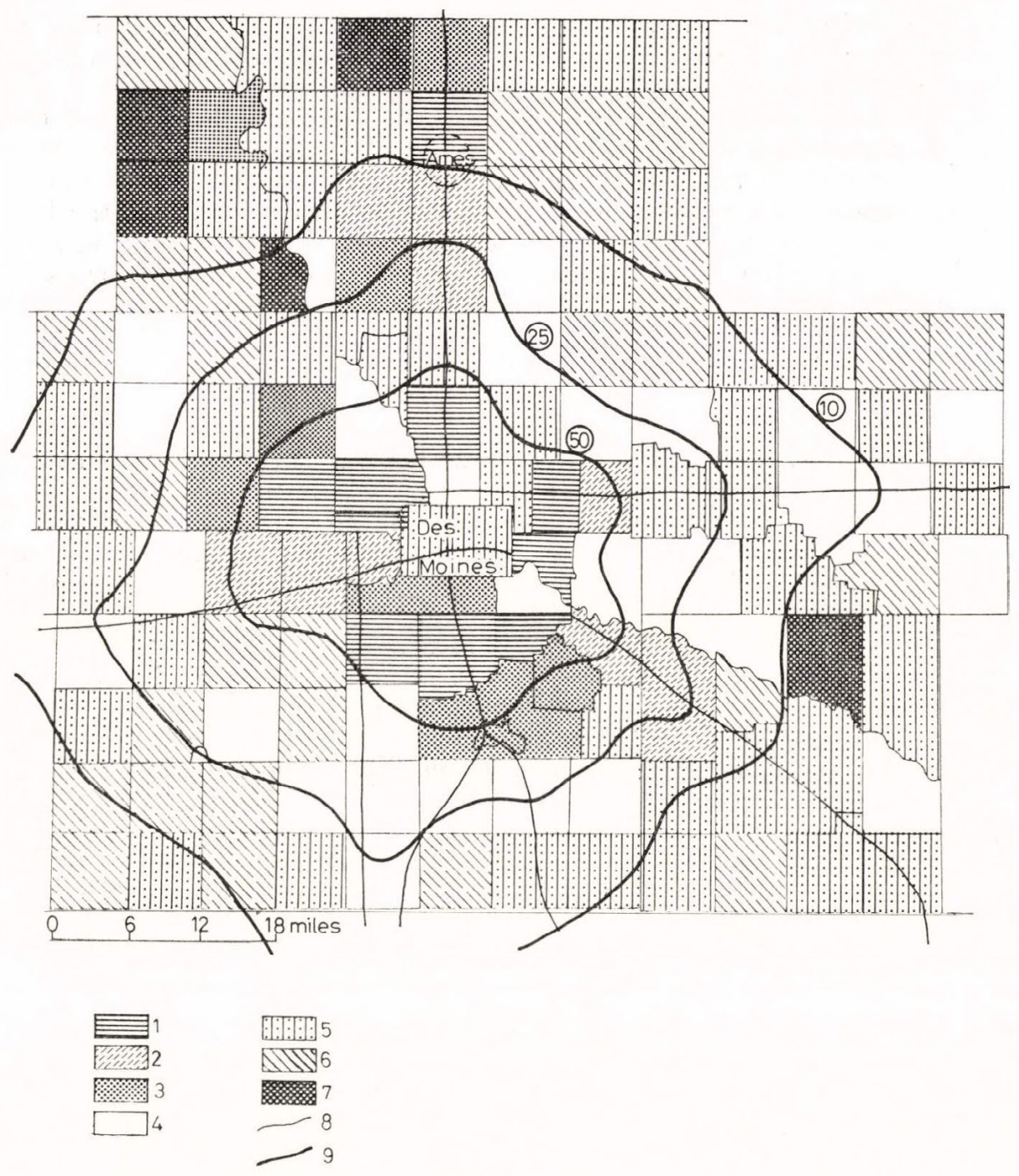

Fig. 1. Population change, Des Moines, Iowa, 1960-70

$1=$ over $50 \%$ gain $; 2=20-50 \%$ gain $; 3=10-20 \%$ gain $; 4=0-10 \%$ gain $; 5=0-10 \%$ loss; $6=10-20 \%$ loss; $7=$ over $20 \%$ loss; $8=$ highways; $9=$ commuting zones

Overall the relations tested concern improvements in income growth and net migration as a consequence of commuting, as related in turn to distance, size of the urban area and region.

As a preliminary illustration consider the Des Moines, Iowa area (Figure 1).

Around Des Moines, which is growing only slowly, and around which rural population was still falling, only the zone with over 50 per cent commuting is 
characterized by strong and consistent growth, the zone with between 25 and 50 per cent commuting by spotty growth, and the zone with less than 20 per cent commuting has more losing than gaining territory.

The graphic profiles in Figure 1 contrast Des Moines with two larger (Atlanta and Seattle) and three faster-growing areas (including Fort Smith, Arkansas). Note particularly that the absolute income increase peaks in the over 25 per cent commuting zone while relative increase is highest in the 10 to 25 per cent commuter zone. Also, all indicators are more favorable in areas with more than a 10 per cent increase in the proportion commuting; for example, net migration is positive $(+5)$ rather than negative $(-6)$.

\section{MAP EXAMINATION}

The set of maps for Atlanta, Seattle, Des Moines and Fort Smith illustrate the findings most readily. Because of the small size of counties, but the large size and growth of the city, and the absence of larger competitors, Atlanta is perhaps the best example. The Atlanta commutershed is extensive and has grown significantly. Still, the commuter zone declines regularly and symmetrically with distance. It should be pointed out that 40 per cent of counties in Georgia lost population in this period, yet within the 10 per cent commuting zone to Atlanta, all but two counties on the extreme edge gained population. Within the 25 per cent commuter zone, including 13 counties, outside the SMSA itself, growth averaged a startling 50 per cent, and at an average distance of miles $(40 \mathrm{~km})$ from Atlanta. Within the 10 per cent commuter zone, another 16 counties, at an average distance of forth miles, grew an average of 20 per cent.

1970 median family income was very high (over $\$ 10,000$ ) within the 50 per cent commuter zone, declining fairly regularly to levels of around $\$ 7000$ at the 5 to 10 per cent levels of commuting. Even the latter level is higher than many regions of Georgia. While median incomes are lower than around Seattle, and about the same as Des Moines, the achievement of these levels is more impressive around Atlanta, given the long term poverty of the region, and the high proportion of Black population (33 per cent in the SMSA).

The absolute income increase is highest in the central counties, but the proportional increase in median income is highest in the next tier of counties, those with between 10 and 40 per cent commuting. It is apparent, finally, from the last map that these areas of greatest relative gain in income are precisely those with most rapid increase in the proportion of the labor force commuting to the central counties (the SMSA).

The patterns in the Seattle-Tacoma area in Washington are similar, but change is much less dramatic in this already more urbanized and higher income area. The commuting zone is also extensive, but increase in commuting and differences in rate of income improvement fairly small. Fort Smith is much smaller $(100,000)$ than Seattle or Atlanta (well over 1,000,000) and is a long time poverty region. However, it experienced a moderate rate of growth and the increase in the proportion commuting was fairly great, a change highly correlated with relative and absolute improvements in income. 


\section{GRAPHIC ANALYSIS}

The graphs trace the behavior of critical indicators or variables for different classes or sets of cities; for larger, medium and smaller sized; for fast, moderate and slow growing; and for four sample cities, Atlanta, Seattle, Des Moines and Fort Smith; all with respect to different levels of commuting or situation within the hinterland; namely separately for the central county, other counties within the SMSA (usually the 50 per cent commuter zone); other counties with over 25 per cent commuting; counties with $10-25$ per cent, and with 2 to 10 per cent commuting. For Des Moines and Atlanta, values were also calculated for counties with more than a 10 per cent or less than a 10 per cent change in the proportion commuting.

The sample cities reflect the national trend of highest rate of growth for medium-sized cities; but low growth for small cities; the low growth of central counties in larger SMSA's, and the displacement of rapid growth to their suburban counties. For all, a decline of growth with distance (less commuting) from the SMSA edge is apparent.

Net migration, highly correlated with rate of population growth, exhibits an identical pattern. Level of 1970 median family income is seen to fall gradually with distance (lower proportions commuting) from the city; and to be distinctly lower for smaller cities.

Absolute income change is generally related to city size, and again gradually falls with distance (lower proportions commuting) from the SMSA. However, a strong inverse pattern of highest proportional improvement in income within the outer commuter zone (10 to 40 per cent) is apparent, particularly around the smaller cities.

Finally, the proportion commuting from beyond the SMSA is inversely related to distance: while larger areas have more extensive commuter sheds, the differences are only very apparent at the outer edge (54, 45 and 37 miles for counties with 2-10 per cent commuting for large, medium and smaller cities).

Classifying cities instead by rates of growth we obviously obtain a clear separation for population growth rate. The peak of growth in the suburban counties of SMSA's is apparent for all classes, as is the decline from there through counties with lower proportions commuting. The patterns for net migration are similar.

Absolute income increase is only weakly differentiated by rate of growth; fast-growing cities experienced significantly higher absolute growth only within the SMSA's.

Proportional income increases are again somewhat more impressive in fastgrowing areas, but again mainly within the SMSA and close suburban counties.

The inverse relation between distance and the proportion commuting is again but weakly differentiated according to rate of growth; faster growing areas having a somewhat more extensive commuter zone than slower growing places ( 50 versus 40 miles for the $2-10$ per cent commuter zone).

The graphs for the sample cities repeat the same conclusions. Relative income increases, but not absolute, were greatest in the poorer hinterlands of Atlanta and Fort Smith, but actual income growth and net migration all

5 Enyedi : Urban 


\section{Table III}

Simple correlations

\begin{tabular}{|c|c|c|c|c|c|c|c|c|c|}
\hline Variant 1 & Variant 2 & All & Big & Medium & Small & Fast & Moderate & Slow & Atlanta \\
\hline $\begin{array}{c}\text { Income, } \\
1970\end{array}$ & $\begin{array}{l}\% \text { commuting, } \\
1970\end{array}$ & $0 \cdot 32$ & $0 \cdot 41$ & $0 \cdot 29$ & $0 \cdot 25$ & $0 \cdot 62$ & $0 \cdot 17$ & $0 \cdot 20$ & $0 \cdot 91$ \\
\hline $\begin{array}{c}\text { Income, } \\
1970\end{array}$ & $\begin{array}{l}\text { Change in } \\
\% \text { commuting }\end{array}$ & $-0 \cdot 22$ & $-0 \cdot 33$ & -0.08 & -0.51 & -0.33 & $-0 \cdot 20$ & $-0 \cdot 12$ & $-0 \cdot 31$ \\
\hline $\begin{array}{l}\text { Income } \\
1970\end{array}$ & Distance & -0.39 & -0.55 & -0.47 & $-0 \cdot 38$ & -0.51 & $-0 \cdot 26$ & -0.39 & -0.91 \\
\hline $\begin{array}{c}\text { Income change } \\
1960-1970 \\
\text { Income change }\end{array}$ & $\begin{array}{l}\% \text { commuting, } \\
1970\end{array}$ & $0 \cdot 37$ & $0 \cdot 49$ & $0 \cdot 37$ & $0 \cdot 16$ & $0 \cdot 76$ & $0 \cdot 01$ & $0 \cdot 11$ & $0 \cdot 83$ \\
\hline $1960-1970$ & Distance & -0.33 & $-0 \cdot 49$ & -0.41 & $-0,31$ & -0.54 & -0.09 & -0.34 & -0.83 \\
\hline $\begin{array}{l}\% \text { change in } \\
\text { income }\end{array}$ & $\begin{array}{l}\text { Change in } \\
\% \text { commuting }\end{array}$ & $0 \cdot 41$ & $0 \cdot 41$ & $0 \cdot 46$ & $0 \cdot 63$ & $0 \cdot 57$ & $0 \cdot 22$ & $0 \cdot 44$ & $0 \cdot 66$ \\
\hline$\%$ population & $\%$ commuting & $0 \cdot 68$ & $0 \cdot 74$ & 0.48 & $0 \cdot 25$ & $0 \cdot 65$ & $0 \cdot 36$ & $0 \cdot 39$ & 0.90 \\
\hline increase & Distance & -0.38 & $-0 \cdot 48$ & -0.42 & -0.25 & $-0 \cdot 62$ & $-0 \cdot 26$ & -0.47 & -086 \\
\hline Net migration & $\%$ commuting & 0.65 & 0.74 & $0 \cdot 36$ & $0 \cdot 18$ & 0.74 & $0 \cdot 34$ & 0.43 & 0.89 \\
\hline $\begin{array}{l}\text { Net migration } \\
0 \% \text { commuting, }\end{array}$ & Distance & $-0 \cdot 37$ & $-0 \cdot 46$ & -0.33 & $-0 \cdot 21$ & -0.57 & $-0 \cdot 28$ & $-0 \cdot 49$ & $-0 \cdot 84$ \\
\hline $\begin{array}{l}1970 \\
\text { Change in }\end{array}$ & Distance & -0.79 & -0.79 & -0.79 & -0.84 & 0.88 & $0 \cdot 78$ & $-0 \cdot 82$ & -0.96 \\
\hline$\%$ commuting & Distance & -0.34 & -0.23 & -0.47 & -0.23 & $-0 \cdot 23$ & -0.56 & -0.01 & $-0 \cdot 10$ \\
\hline Income change & $\begin{array}{l}\% \text { population } \\
\text { increase }\end{array}$ & $0 \cdot 66$ & 0.54 & $-0 \cdot 14$ & $0 \cdot 59$ & $0 \cdot 66$ & $0 \cdot 16$ & $0 \cdot 64$ & $0 \cdot 79$ \\
\hline $\begin{array}{l}\% \text { population } \\
\text { increase }\end{array}$ & Net migration & $0 \cdot 97$ & 0.99 & $0 \cdot 94$ & $0 \cdot 96$ & $0 \cdot 97$ & $0 \cdot 98$ & $0 \cdot 95$ & 0.995 \\
\hline
\end{tabular}

Correlations over $0 \cdot 25$ are significant, $0 \cdot 01$ ) 
TABLe IV

Significant independent variables, overall correlation

\begin{tabular}{|c|c|c|c|c|c|c|c|c|}
\hline Dependent variable & Big & Medium & Small & Fast & Moderate & Slow & Atlanta & All \\
\hline $\begin{array}{l}\text { 1. } \% \text { increase } \\
\text { Income }\end{array}$ & $\begin{array}{l}0 \cdot 59 \\
2,10\end{array}$ & $\begin{array}{c}0 \cdot 70 \\
1,2,9,10\end{array}$ & $\begin{array}{c}0 \cdot 74 \\
4,7,9,10\end{array}$ & $\begin{array}{c}0 \cdot 67 \\
1,2,10\end{array}$ & $\begin{array}{c}0 \cdot 54 \\
1,2,7,10\end{array}$ & $\begin{array}{l}0 \cdot 60 \\
7,10\end{array}$ & $\begin{array}{c}0 \cdot 77 \\
1,2,4,7,10\end{array}$ & $\begin{array}{c}0 \cdot 51 \\
1,2,7,9,10\end{array}$ \\
\hline $\begin{array}{l}\text { 2. } \% \text { commuting } \\
1970\end{array}$ & $\begin{array}{c}0 \cdot 88 \\
1,7,8,9\end{array}$ & $\begin{array}{c}0 \cdot 82 \\
1,2,7,9\end{array}$ & $\begin{array}{c}0 \cdot 91 \\
1,2,7,9\end{array}$ & $\begin{array}{c}0 \cdot 90 \\
1,2,7,9\end{array}$ & $\begin{array}{c}0 \cdot 86 \\
1,2,7,9\end{array}$ & $\begin{array}{c}0 \cdot 87 \\
1,2,7,9\end{array}$ & $\begin{array}{c}0 \cdot 98 \\
1,2,7,8,10\end{array}$ & $\begin{array}{c}0 \cdot 84 \\
1,2,7,8,9,10\end{array}$ \\
\hline $\begin{array}{l}\text { 3. } \% \text { population } \\
\text { Growth }\end{array}$ & $\begin{array}{c}0 \cdot 77 \\
4,7,9,10\end{array}$ & $\begin{array}{c}0 \cdot 64 \\
4,6,7,9\end{array}$ & $\begin{array}{c}0 \cdot 48 \\
4,6,7,9\end{array}$ & $\begin{array}{l}0 \cdot 84 \\
4,7,9\end{array}$ & $\begin{array}{l}0 \cdot 36 \\
4,10\end{array}$ & $\begin{array}{c}0 \cdot 68 \\
4,7,9,10\end{array}$ & $\begin{array}{c}0 \cdot 91 \\
4,7,10\end{array}$ & $\begin{array}{c}0 \cdot 71 \\
4,7,8,9,10\end{array}$ \\
\hline 4. Net migration & $\begin{array}{c}0 \cdot 77 \\
4,7,9,10\end{array}$ & $\begin{array}{c}0 \cdot 67 \\
4,6,7,9\end{array}$ & $\begin{array}{c}0 \cdot 44 \\
4,6,7,9\end{array}$ & $\begin{array}{l}0 \cdot 77 \\
4,7,9\end{array}$ & $\begin{array}{l}0 \cdot 35 \\
4,10\end{array}$ & $\begin{array}{c}0 \cdot 66 \\
4,7,9,10\end{array}$ & $\begin{array}{l}0 \cdot 90 \\
4,7,10\end{array}$ & $\begin{array}{c}0 \cdot 68 \\
4,7,8,9,10\end{array}$ \\
\hline $\begin{array}{l}\text { 5. change in } \\
\% \text { commuting }\end{array}$ & $\begin{array}{r}0 \cdot 49 \\
1,2,6\end{array}$ & $\begin{array}{r}0 \cdot 66 \\
1,2,6\end{array}$ & $\begin{array}{l}0 \cdot 77 \\
1,2,6\end{array}$ & $\begin{array}{l}0 \cdot 61 \\
6\end{array}$ & $\begin{array}{c}0 \cdot 62 \\
6,7\end{array}$ & $\begin{array}{c}0 \cdot 67 \\
1,2,6,7\end{array}$ & $\begin{array}{c}0 \cdot 70 \\
6\end{array}$ & $\begin{array}{l}0 \cdot 52 \\
6,7\end{array}$ \\
\hline $\begin{array}{l}\text { 6. Income change } \\
1960-1970\end{array}$ & $\begin{array}{c}0 \cdot 86 \\
1,2,8,10\end{array}$ & $\begin{array}{c}0.95 \\
1,2,8,9,10\end{array}$ & $\begin{array}{c}0 \cdot 95 \\
1,2,8,9,10\end{array}$ & $\begin{array}{c}0 \cdot 90 \\
1,2,8,9,10\end{array}$ & $\begin{array}{c}0 \cdot 90 \\
1,2,8,9,10\end{array}$ & $\begin{array}{c}0 \cdot 95 \\
2,8,9,10\end{array}$ & $\begin{array}{c}0 \cdot 94 \\
1,2,7,8,10\end{array}$ & $\begin{array}{r}0 \cdot 88 \\
4,8,8,10\end{array}$ \\
\hline 7. Income, 1970 & $\begin{array}{r}0 \cdot 62 \\
2,4,7\end{array}$ & $\begin{array}{l}0 \cdot 62 \\
2,7\end{array}$ & $\begin{array}{c}0 \cdot 77 \\
1,2,4,7\end{array}$ & $\begin{array}{l}0 \cdot 64 \\
2,4\end{array}$ & $\begin{array}{l}0 \cdot 45 \\
2,4\end{array}$ & $\begin{array}{r}0 \cdot 68 \\
2,4,7\end{array}$ & $\begin{array}{c}0 \cdot 92 \\
1,2,4,7\end{array}$ & $\begin{array}{l}0 \cdot 42 \\
2,4,7\end{array}$ \\
\hline
\end{tabular}

Variables:

1. \% population growth

3. \% population increase
4. $\%$ commuting, 1970

6. $\%$ income increase

7. Distance

8. Income, 1970

5. Income change, 1960-1970

9. Population of urban area

10. Change in $\%$ commuting 
declined as the proportion of commuting does, with distance. For Atlanta and Des Moines, the indicators are all more positive for counties with over a 10 per cent increase in the proportion commuting; Des Moines, as a smaller and slower-growing city, is always in a lower relative position.

\section{STATISTICAL ANALYSIS}

The principal simple correlations are shown in Table III. Only those relating commuting, and/or distance to indicators of success will be discussed.

The expected positive relation between 1970 income and the proportion commuting is supported, especially in the Atlanta sample, but this mainly holds for larger and/or faster-growing cities. The similarly expected inverse relation between 1970 income and distance is of the same pattern, and slightly stronger and more consistent. The inverse relation between income and change in the proportion commuting indicates that the richest areas already have achieved high and perhaps saturation levels of commuting.

Change in income is likewise positively related to the proportion commuting and inversely with distance, with approximately the same pattern as with 1970 income itself. The most satisfying finding of the analysis is perhaps the generally very good direct relation between the per cent increase in income and change in the proportion commuting - a relation opposite to that with the current income level. These areas of increasing commutation, out beyond the zones of highest income and commuting, are those experiencing the greatest relative improvement in status.

Population increase, and net migration, which have an extremely high correlation $(0.95-0.995)$ are also, as expected, directly related to the proportion commuting and inversely with distance. Again these relations are stronger for larger and faster growing cities, especially Atlanta. Finally the relation of the proportion commuting to distance is, as expected, consistently strong for all categories of cities.

Regression analyses were used to test some of these relations (Table IV). County variation in 1970 income is only moderately accounted for ( $r$ 's $=0.5$ to 0.8 ) by variation in the proportion commuting, net migration and distance, except for Atlanta $(r=0.92)$.

The Atlanta equation:

Income $1970=\$ 9458+19 \cdot 6$ (per cent commuting, 1970) $-49 \cdot 0$ (distance) illustrates the interplay of commuters and distances, e.g. at 5 miles, if commuters were 70 per cent, the result would be approximately $9458+1400$ $-250=$ C. $\$ 10,600$, while at 50 miles, if commuters were 10 per cent, the results would be $9438+200-2500=$ C. $\$ 7150$.

Income change by county is very well accounted for by several other variables ( $r$ 's 0.85 to 0.95 ); especially population growth, net migration population of the urban area, and change in the proportion commuting. Greater increases are associated with faster growing larger cities, and increases in the proportions commuting.

The equation for all cities is :

Income change (1960-1970) $=\$ 143+24 \cdot 7$ (change in per cent commuting) 
+0.38 (1970 Income, 000's) + 5.7 (per cent commuting, 1970)

+0.21 (Population, urban areas, 000's)

For the mean values of the variables the results are:

$$
\begin{aligned}
\text { Income Change } & =\$ 143+24 \cdot 7(5 \cdot 0)+0 \cdot 38(8250)+5 \cdot 7(18)+0 \cdot 21(501) \\
\$ 3611 & =\$ 143+125+3135+103+105
\end{aligned}
$$

Proportional increase in income is not so readily explained ( $r$ 's $=0.51$ to 0.77 ), but higher rates of increase are strongly related to increase in the proportion commuting and more weakly related to distance (directly, as expected) and with size of the urban area. The Atlanta equation is

$\%$ Income increase $=73+0.015(\%$ commuting, 1970) +2.6 (Change in $\%$ commuting)

or pretty much a function of increase in the proportion commuting. For the mean values: $89 \cdot 1=73 \cdot 0+0 \cdot 5+15 \cdot 6$

The hypothesis that, with increasing size, the commuter sheds extend but less than proportionally, is supported by these equation parameters:

(1) Proportion commuting $=\frac{14 \cdot 3 \text { Population }^{0 \cdot 66} \text { Non-urbanized, } \% 0^{\mathbf{0} \cdot 5}}{\text { Distance }(\text { miles })^{1 \cdot 79}} R=0 \cdot 86$

(2) Proportion commuting $=$

$=64.1 e^{-0.096}$ distance +0.002 population +0.0077 non-urbanized $R=0.96$

where population is of urbanized areas (in 000's); and 'non-urbanized' means the proportion of a county not in an official urbanized area. This has the effect of dampening values at extremely close distances and in counties which are intervening centers.

It is rather interesting, that despite the tremendous American mobility, the distance decay of commuting approaches the traditional $D^{2}$ of pure theory; however, the low exponent of distance means that a very large increase in population results in proportionally a much smaller increase in the distance at which a given proportion commutes.

Population increase and net migration, being virtually interchangeable, are generally fairly well accounted for by variations in the proportions commuting, change in this proportion, size of the urban area and distance (inverse again now).

The Atlanta equation is:

$\%$ population change $=2.4+0.91(\%$ commuting, 1970) +0.36 (change in $\%$ commuting)

For the mean values: $36 \cdot 1=2 \cdot 4+31 \cdot 5+2 \cdot 2$

For all cities:

$\%$ population change $=5 \cdot 2+0.88(\%$ commuting, 1970) -0.87 (change in

For the mean values

$$
\% \text { commuting) }-0.12 \text { (distance) }
$$

$16 \cdot 7=5 \cdot 2+16 \cdot 0-4 \cdot 5$

Finally, the relation between distance and the proportion commuting is strong and is readily described by the usual exponential or gravity-model equations. Size of urban area enters to increese the proportion commuting at a given distance, but very much less than proportionally to the larger size. 
The beneficial effects of commuting, on the basis of all the above results, gradually gave way to conditions of out-migration, lower income, and population loss. The data analyzed here do not indicate whether the growing city necessarily aggravates the decline in its own hinterland (people might leave for a more distant place if there were none locally), but study of migration fields do indicate a predominantly local origin.

Our data indicated the following (Table V):

\section{TABLE V}

Mean distance in miles (in absence of competing growth centers)

\begin{tabular}{l|c|c}
\hline \multicolumn{1}{c|}{ Cities } & $\begin{array}{c}\text { Out-migration } \\
\text { occurs }\end{array}$ & $\begin{array}{c}\text { Population loss } \\
\text { occurs }\end{array}$ \\
\hline Fast-growing & 50 & 60 \\
Moderate & 35 & 50 \\
Slow & 15 & 30 \\
Large & 45 & 55 \\
Medium & 40 & 50 \\
Small & 25 & 40
\end{tabular}

Variations in rate of growth have a somewhat greater influence on the distance at which poorer conditions prevail than do variation in size. In actually declining urban areas, of whatever size, these indicators are negative throughout the area, except perhaps in suburban counties.

The hypothesis that faster growing cities will experience greater increases in proportion commuting and extend their hinterlands further is not well supported by the data (Table VI).

\section{TABLE VI}

Distance at which commuting reaches specific levels

\begin{tabular}{|c|c|c|c|c|c|}
\hline & & \multicolumn{2}{|c|}{ Faster } & \multicolumn{2}{|c|}{ Slower } \\
\hline & & 1960 & 1970 & 1960 & 1970 \\
\hline \multirow[t]{4}{*}{ Large: } & 50 per cent & 18 & 22 & 12 & 15 \\
\hline & 25 & 30 & 36 & 24 & 30 \\
\hline & 10 & 44 & 50 & 30 & 36 \\
\hline & 5 & 50 & 60 & 40 & 45 \\
\hline \multirow[t]{4}{*}{ Medium: } & 50 & 10 & 15 & 10 & 15 \\
\hline & 25 & 15 & 25 & 15 & 20 \\
\hline & 10 & 25 & 33 & 20 & 30 \\
\hline & 5 & 35 & 40 & 25 & 35 \\
\hline
\end{tabular}

Note: Data are inadequate for small cities. The sample slower-growing larger cities are also much smaller than the fast-growing ones.

Differences in commuter shed extent are not significant as between fast, medium and slow growing cities. Access and higher mobility seem more signif- 
icant to the properties commuting than the relative success of the place. However, it remains true that increases in commuting are strongly related to population and income growth.

Statistical summary: with respect to the original hypotheses:

1. a decline in commuting, with distance

2. greater improvement in income associated with increase on the proportion commuting

3. decline in growth, net migration and income with decline in per cent commuting

4. greater relative change in poorer areas; but perhaps greater absolute change in richer areas

5. decline in population, out-migration and lower income beyond the commuter zone

6. increased population extends commuter shed, but less than proportionally to size

7. greater growth is associated with greater increases in proportion commuting, and larger extensions of the commuter shed.

The first six hypotheses are supported rather well, the last only partially. The decline in commuting with distance (1) is certainly not very interesting in itself, but the displacement of improvement in growth and income in the zone of increasing commuting (2), (3) is a significant finding. Greater relative improvement in poorer areas (4) was corroborated, while greater absolute income increments were experienced in larger and/or richer areas.

Population decline, severe out-migration (5) were found to occur generally beyond the 5 per cent commuter zones around slower-growing or poorer cities (like Des Moines, Birmingham), but does not occur if the commutershed overlaps with those of other cities (e.g. New York, Seattle).

Increasing population was found to extend the commutershed much less than proportionally, but the zone of more intense commuting at a given intensity is displaced between 5 and 10 miles outward as between larger and medium cities and between medium-sized and larger cities.

Increases in commuting, and extension of the commuter zone, beyond the inner, high commuter zone, were found to be strongly associated with high rates of population growth, and faster-growing cities were found to have slightly larger commuter sheds. However, differences in commutershed extended by rate of growth were not significant.

It should finally be emphasized that the statistical results do not justify any strong causal relations, in as much as the processes of growth, migration, commuting, and income generation are simultaneous and interdependent. What we can say, however, is that in the absence of a growing center and the spread of its commutershed, that growth in population, immigration and income are not very likely to take place. 


\section{CONCLUSION}

The preceding studies are but beginnings of intended larger scale studies, including similar analyses of more places, but also more intensive study of a few places. As indicated in the introductory pages, the hope is to extend the study to investigate the patterns and locations of expenditures so that some estimates of actual net income transfers as a result of commuting can be made.

These studies corroborated the widespread observation of city impact on hinterland, from loss of farmland, to tourist travel, to suburbanization and exurbanization, but also tried to measure some of these impacts more precisely - particularly the relation between commuting and income, and change in commuting and change in income and their further relation to population growth, size of urban place, net migration and distance. 


\section{INDUSTRY IN HUNGARIAN TOWNS}

By

ÁKOS BORAI

\section{INFLUENCE OF INDUSTRY ON THE DEVELOPMENT OF HUNGARIAN TOWNS}

In the second half of the 19th century economic development, especially industrialization, furthermore transportation facilities surmounting spatial differences between places of production and consumption as well as building up of a modern (railway and road) transport system played an outstanding part in the rapid processes of urbanization and transformation of the settlement network.

\section{INDUSTRIAL DEVELOPMENT AFTER THE COMPROMISE OF 1867}

The Compromise of 1867 considered as a landmark in the final liquidation of vestiges of feudal relations of production gave the impetus for large-scale capitalist economic and social development within the framework of the AustroHungarian Monarchy.

The regional division of labour that came into being was favourable first of all processing agricultural products, that is to developing the towns of the Great Hungarian Plain. At the same time, however, possibilities for Hungarian industrial development within the historically inherited industrial spatial structure were rather restricted by the more competitive industries in Austria and her hereditary provinces.

In the decades following the Compromise large-scale railway construction was undertaken in order to export surplus agricultural products, but also to overcome a shortage of capital heavily weighing on the large estates. As a result of its multiplier effect, railway construction stimulated the exploiting and processing of mineral resources as well.

The Hungarian railway network considerably accelerated the development of Budapest, the second capital of the dual Monarchy, were a high-capacity concentration of food (milling, beer, meat, canned food, dairy products) industries had been set up.

Industry excelled not only by its dynamism and basic role played in the country's economic life, but it also became a decisive factor in the transformation of the urban network. The Hungarian capital which was becoming more and more significant in the Carpathian Basin, turned into a regional center, under whose influence counterpoles beyond the country's present borders could begin large-scale development (Arad, Temesvár-Timişoara, NagyváradOradea, Szabadka-Subotica, Pozsony-Bratislava, Kassa-Košice, ZágrábZagreb). At the same time Budapest, situated in the center of the Hungarian Central Mountains, gave with its ever increasing basic material demands a stimulus to prospecting and exploiting mineral raw material resources of this 
area as well as to the urbanization of the industrial settlement based on the coal fields.

From among the towns situated at the north-eastern end of the Hungarian Central Mountains, Salgótarján with its small population owed its dynamically developing heavy industry to its significant Lower Miocene coal occurrences. A new railway line (Pest-Hatvan-Salgótarján) opened to traffic in 1867 laid the foundation of metallurgy, electric energy and building industries. In addition to the Salgótarján Steel Goods Factory Inc. founded by the Rimamurány-Salgótarján Ironworks (RIMA) Inc., the Salgótarján Blown Glassware Plant (1893) and the thermal power station of the Salgótarján Electricity Co. Inc. (1895) were;also located near the local pits.

Just as in the case of the town of Salgótarján, the stimulative influence of Miocene brown coal exploitation can be recognized in the development of other large settlements in the Sajó river valley as well. Keeping in view the local coal fields, the RIMA Inc. established a high-capacity ironworks, a Siemens-Martin-type furnace and roll mill at the town of Ozd. After the completion of the railway line, a blast furnace, a Siemens-Martin-type as well as roughing and small-section rolling mills were set up by the Hungarian State Iron, Steel and Machine Works (MÁVAG) on the outskirts of Miskolc, at the entrance of the Sajó river valley. At the same time the metallurgical basis located originally on the coal fields has now become one of the centers of Hungary's heavy machine building, electric energy production and building material industry.

The foundation of industrial development at the southwest end of the Hungarian Central Mountains (in Transdanubia) also lay in coal deposits. For instance, various types of mining in the Dorog Paleocene-Eocene coal basin (Dorog, Tokod, Sárisáp, Mogyorós) contributed to the development of transport (steamship navigation - First Danube Shipping Company) and to the industrialization of Pest county (Quarry and Brickworks Company) as early as the second half of the 19th century. However, the encouraging development of coal production was not able to promote the urbanization of the small mining settlements, due to the fact that they became part of the modern railway network only much later.

At Tatabánya there was a more dynamic development than in the settlements of the Dorog coal basin. Here in the year of the Hungarian millennium (1896) considerable coal deposits were discovered. As a result of favourable settlement and structural conditions as well as in consequence of good transport opportunities, Tatabánya's coal mining output began to grow at a rapid pace. Having taken possession of the coal mining licences, the Hungarian State Coal Mining Company (MÅK) put in operation first at Tatabánya, then at Bánhida 40 and 60 MW-capacity thermal power stations, respectively. In addition, in the center of the exploitation area it established a briquetting plant, too (1902). On the Paleocene-Eocene coal and Triassic-Dachstein limestone occurrences the company MÁK set up a lime burner (1904) and a limesand brickworks (1909). At the same place a high-capacity portland-cement plant came later into operation (1912).

In the southern area of the Hungarian Central Mountains, in the Mecsek mountains, Lower Lias coal deposits were known as early as the end of the 
18th century. Their systematic exploitation, however, became one of the indicators of the industrial development of Pécs only in the period after the Compromise of 1867, after the Danube Shipping Company (DGT) had put into operation a coking plant (1861), a briquetting plant (1867) and an electric energy station (1914), simultaneously with the boosting of coal mining.

Local coal occurrences also played an important role in the flourishing light, food and building material industries of Pécs.

In the towns of the Little Hungarian Plain situated geographically in the neighbourhood of Austrian and Czech industries and producing for the Austrian market, a highly developed agricultural industry (food, light, machine industries) was established, having an incentive effect on the further development of the towns concerned (Győr, Sopron, Szombathely, Pápa), which began to acquire urban features.

As can be concluded even from our abridged analysis, transport played an outstanding role in the development of towns with long historical backgrounds and located at the crossing points of different production areas. As a result of the nodal focussing of the Hungarian railway lines, transport not only increased the predominance of the industry concentrated in Budapest, but also created favourable conditions for urbanizing formerly rural settlements lying along the industrial axis abounding in energy resources and mineral raw materials. This may to a great extent account for the fact that by the turn of the century most of the towns being industrialized overtook in population number the large market towns in the Great Hungarian Plain that had long historical backgrounds and were situated in the center of significant agricultural areas.

\section{BETWEEN THE TWO WORLD WARS}

In consequence of the territorial changes that took place after the First World War, the importance of the settlements engaged in exploiting and processing raw and basic materials increased. Since Budapest lost its former sphere of stretching beyond Hungary's new borders, its large industry curbed the development of the settlements with similar structure, situated in the capital city's attraction field. In spite of this fact, in the period between the two world wars industry remained a significant factor of urbanization.

In the new economic system that came into being after the disintegration of the Austro-Hungarian Monarchy, development was realized mostly in the larger settlements of the "industrial axis" of the Hungarian Central Mountains. With knowledge of significant bauxite reserves discovered in the Bakony Mountains (Gánt), the Bauxite Trust Inc., a firm with German shares, established an alumina plant at Mosonmagyaróvár in 1936, followed later on by the foundation of two other alumina plants at Almásfüzitő and Ajka respectively. At the same time the development of the aluminium industry required increasing electricity capacity and the vertical integration of bauxite processing. The industrial location programme greatly facilitated the strengthening of the urbanization processes of Ajka and Tatabánya. The process is marked by the establishment of the Carbide Plant (1921) and the Bauxite- 


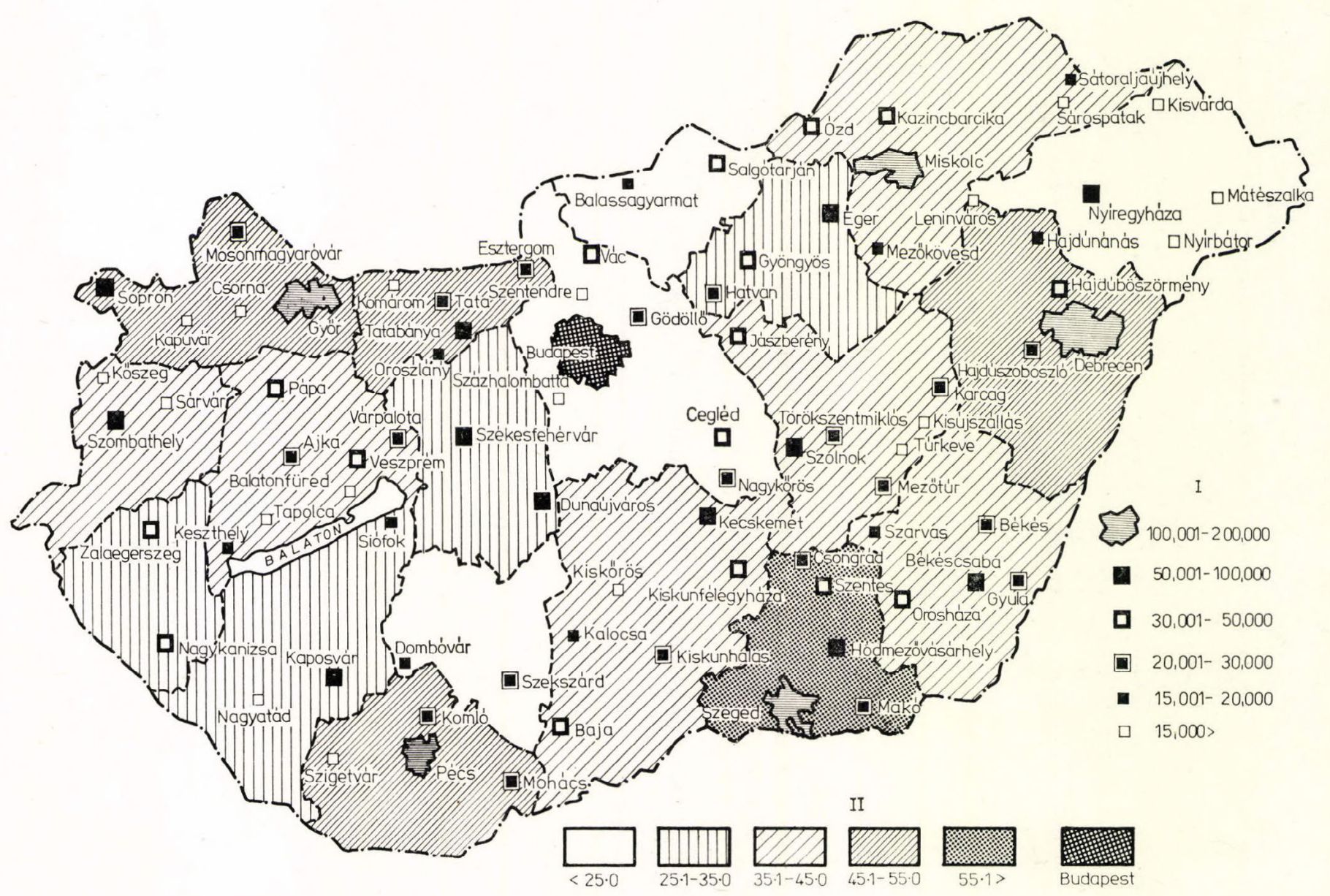


Cement Plant (1928), both at Tatabánya, followed by the putting into operation of an aluminium furnace in Mosonmagyaróvár (1938).

A second center of aluminium processing was intended to be developed at the center of the coal basin near Alsócsingervölgy. Having taken into account the Upper Cretaceous coal reserves, the building of an alumina plant was started at Ajka. It was planned to satisfy its steam needs by means of a 52.5 MW capacity thermal power station, but owing to the outbreak of World War II the aluminium furnace could not be put into operation, although the complementary investment in connection with the aluminium industry later played a significant role in Ajka's process of urbanizations.

After World War I considerable concentration of the chemical industry came into being in the area north of Lake Balaton, which significantly contributed to the industrial development of Várpalota. Being the legal successor to the Várpalota Industrial Establishment Inc. (1907) exploiting Miocene lignite, the Union Inc. set up a thermal power station and a hydration plant, both in the center of the coal basin. Its aim was to facilitate putting into operation the Nitrochemical Plant at Füzfö (1921), the Industrial Explosive Factory at Peremarton (1929) and the Nitrogen Works at Pét-Várpalota (1930).

In spite of certain efforts to decentralize industrial capacity by means of the division of labour, a considerable share remained concentrated in Budapest. As a result of dynamic development, the importance of light industry (cotton, knitting, haberdashery, ready-to-wear, leather and skin as well as shoe industries), engineering industry (precision engineering, production of electric machines and appliances, manufacture and overhaul of vehicles) and chemical industry (production of pharmaceuticals) increased.

Skilled labour force, high-level technical and social infrastructure, favourable opportunities for cooperation as well as steadily growing consumer demands on the part of the city's population - all played an outstanding role in creating a considerable industrial capacity.

In spite of the industrial development of the country towns a major part of Hungary's industrial potential continued to be concentrated in the capital (Figure 1).

\section{INDUSTRIAL DEVELOPMENT IN THE POST SECOND-WORLD-WAR PERIOD}

Large-scale industrialization played a major part in the process of urbanization and urban network development after the Liberation in 1945.

Fig. 1. Process of urbanization - according to the data of the Hungarian Central Statistical Office

I. Development of towns: 1 = before Jan. 1, 1955; 2 = between Jan. 1, 1955-Dec. 31, 1959; $3=$ between Jan. 1, 1960 - Dec. 31, 1969; $4=$ towns created after Jan. 1, 1970; $5=$ villages marked out for urban development. II. Share of urban population on Jan. 1, 1974, in per cent 
Dynamic industrial development based on the social ownersh ip of means of production can be divided into two closely linked periods, in accordance with the country's economic-political objectives.

As a result of the extensive development of heavy industry, the industrial potential of the country enlarged at first only in the capital city and in the towns of the "industrial axis" running parallel to the range of the Hungarian Central Mountains (1945-1960). However, the historically inherited spatial structure played a significant role not only in the volume of the economic potential, but also in some regional differences in income conditions and living standards of the population. That is why at the later stage industrialization (1960-1975) developing an up-to-date industrial structure and promoting an even regional distribution of industry became the major task. On the other hand, promoting the development of towns lying in the backward farming areas required the locating of industrial plants of a variable character.

\section{a) Period of development of heavy industrial towns}

In the tense international situation (1950-1955) the development of heavy industry came to the fore. However, broadening the metallurgical and machine industrial capacities with their high basic material, energy and manpower requirements respectively, had to be coupled with increasing the production targets of coal mining, electric energy and building material industries as well.

Most of the basic industrial plants (iron and metal production, etc.) were located in the major settlements, which resulted in fast growth of these long established towns. On the other hand, in the centers of fuel and basic material occurrences, industrialization brought into being new "socialist" towns (Dunaújváros, Kazincbarcika, Komló, Oroszlány, Várpalota).

The country's new metallurgical combine (the Danube Metallurgical Works) was set up at Dunaújváros. This town becoming later a partial higher administrative and educational center owed its development to the Danube Metallurgical Works, at which furnaces (I-II), steel mill, hot rolling mill, thermal power station, ore dressing works, coking plant, engineering works and fire clay plant, etc. have been erected.

In a great part of the newly established towns (at Kazincbarcika in 1955, at Komló in 1955 and at Várpalota in 1951) new condensing thermal power stations have been built, this being a precondition for the location of new metallurgical plants (the Almásfüzitő Alumina Plant, the Inota Aluminium Furnace, the Székesfehérvár Light Metal Works) and industrial enterprises (the Borsod Chemical Works, the Tisza Chemical Works, etc.).

Engineering plants with a high manpower requirement (the Vacuum Engineering Factory of the United Lamp Works "Tungsram", the Ganz Switches and Appliances Factory) have been built in the capital city as well as in some provincial towns disposing of relatively favourable endowments from the aspects of public and social services. So the following plants were put into operation: the Ganz Electric Supply Meter Factory (1950) at Gödöllö, the Rail- 
way Switch Producing Enterprise of the Hungarian Railways (1952) at Gyöngyös, the Medical Instrument Factory (1950) and the Roller Bearing Factory (1960), both in Debrecen, the Factory of Grinding Machines (1951) at Jászberény, the Cutting Tools Factory (1951) at Békéscsaba, the Cable and Wire Plant (1960) in Szeged, the Scales Factory (1951) in Hódmezővásárhely, etc.

The light industry was represented by some textile factories (Kaposvár, Miskole, Szeged) and textile clothing plants (Békéscsaba, Zalaegerszeg), the food industry by a brewery (Nagykanizsa), a tabacco-drying shed (Nyíregyháza) as well as several cooling-houses.

The industrial development of the towns was mostly of an extensive character, since production capacity was increased first of all by creating new working places. As a result of this fact, a large part of the working force freed from agriculture found new employment in urban industries. The large-scale professional switch-over and migration of earners, however, swelled overnight the population number of the greater settlements (towns). In consequence of the fact that dwelling-house building did not everywhere keep up with the growth of industrial capacity, the number of commuters travelling daily to and from the towns increased extraordinarily.

\section{b) Urban development during the period of mixed industrial expansion}

At the second stage of Hungary's post-war industrial development, the country's economic policy was directed at correcting the heavy industrial structure that had previously been developed one-sidedly as well as at industrializing the backward agricultural areas. That is to say the reserves (labour force) for further extensive industrial development had already been exhausted.

In view of the fact that industrial potential had mostly been concentrated in Budapest, the capital city of the country and in the towns of the "industrial axis" running parallel to the range of the Hungarian Central Mountains, intensive development and structural modernization became the most timely tasks ahead. At the same time this endeavour was also in accordance with the requirement of creating an up-to-date energy structure, and the decision to eliminate existing regional differences in living standards. The government envisaged achieving these targets by industrializing backward agricultural areas.

Creating a proportional industrial spatial structure was inseparable from the removal to the country of some of the plants concentrated in the capital. At the beginning of the second five-year-plan period (1960-1965) $32 \cdot 7$ per cent of the country's whole industrial fixed assets, and $41 \cdot 1$ per cent of the country's total work-force engaged in industry were employed in Budapest (1960).

A major part of the Hungarian capital's multifold industrial production consisted of products requiring high manpower and specialist knowledge. Despite the numerous advantages stemming from cooperation, the difficult labor force supply was turning more and more into an obstacle in the way of industrial structure modernization. Namely infrastructure and service re- 
lating directly or indirectly to production could not keep up with the fast development of industrial capacity (pharmaceutical industry, rubber and plastic material processing, precision engineering, telecommunications and vacuum engineering). In order to eliminate overcrowding and to diminish environmental damage, all the Budapest plants have been reviewed and divided into three groups, on the basis of their functions. Enterprises placed into Group I and Group II have been left in the capital city. Those of Group I have been given the "green light" for further development. Those of Group II have also remained in Budapest but they were not allowed to grow in size. The plants placed into the Group III, however, were compelled to leave the capital. At the same time provincial towns interested in locating and developing industry were granted considerable financial support. These subsidies were completely justified, taking into consideration that these towns with backward industry had to modernize and broaden their technical and social infrastructure connected with production.

It is typical of the results of the relocation process that during the fourth five-year-plan period 65 plants and 136 industrial sites were wound up in the capital, creating thereby possibilities for establishing 23,860 new working places in the country.

With few exceptions the industrial plants partly newly founded and partly removed from the capital found themselves new homes in towns. Although during the period under review considerable hydrocarbon reserves had been discovered in some economically backward agricultural regions (for instance in the north and south of the Great Hungarian Plain), our economic policy mostly facilitated the expansion of industrial plants with a high manpower requirement. (Except for the food industry, with a high transportation requirement.) At that time the utilization of modern energy resources was still not important in industrial location.

Due to the disadvantageous situation, industrial development was in some of the country towns of an extensive character. But industrial establishments requiring lower qualifications and disposing of less modern machinery have been more and more replaced by plants employing qualified labour and up-todate technology. As a matter of fact, after the large-scale development following the collectivization of agriculture, the amount of labour freed from agriculture later decreased. In consequence of the mechanization of cultivation and stock breeding as well as owing to the auxiliary activities of producers' cooperatives related to industry and building industry, living conditions of the population have become favourable in many rural settlements. Multilateral analysis of the town's industrial location endowments, and survey of their labour supply have become one of our inevitable major tasks ahead. Chiefly this may account for the fact that contrary to the previous period of development, instead of locating heavy industrial plants, location of varied medium-sized industrial plants has become general. Such plants can elastically adapt themselves to the local conditions and consumers' demands. Among these "dynamic" industrial branches with up-to-date technology we can find the various sub-branches of machine engineering (at Baja, Eger, Hódmezövásárhely, Gyöngyös, Kecskemét, Szolnok, Szombathely, etc.), the telecommunication and vacuum engineering (at Kaposvár, Kecskemét, Székesfehér- 
vár, Vác, etc.) as well as the chemical industry (at Dunaújváros, Győr, Kazincbarcika, Leninváros). Besides the capacity of manufacturing industry, light (wood, paper and printing, textile) industrial establishments (at Baja, Békéscsaba, Hódmezővásárhely, Eger, Makó, Mohács, Sopron, Szeged, etc.) and food industrial plants processing the agricultural products of the surroundings (at Hajdúböszörmény, Békésesaba, Kalocsa, Kecskemét, Mohács, Szegëd etc.) were getting more and more numerous.

In addition to the towns of the agricultural areas (Békéscsaba, Debrecen, Kecskemét, Kiskunfélegyháza, Szeged, Szolnok, Nyíregyháza, etc.) plants with a high manpower requirement have been put into operation also in the heavy industrial concentrations (Komló, Pécs, Oroszlány, Tatabánya, Kazincbarcika, Miskolc, Ózd) in order to ensure adequate employment opportunities for the work force freed from mining. (Transformation of energy structure.)

During the past decade only Leninváros (Tisza Chemical Works, Olefinic Works, Tisza Oil Industrial Enterprise) and Százhalombatta (Danube Oil Industrial Enterprise, Danube Thermal Power Station) have owed their advance town to the location of heavy industrial plants there.

\section{CHARACTERISTICS OF URBAN INDUSTRY}

About half of Hungary's population ( 49.5 per cent) lives in towns, in which 77.4 per cent of the country's stock of fixed assets and 77.5 per cent of its industrial earners are employed (1975).

It is typical of the unequal regional distribution of urban population $(5,165 \cdot 8$ thousand persons on the whole $)$ that $39 \cdot 7$ per cent of them are to be found in the capital and $15 \cdot 6$ per cent in the larger provincial towns constituting the counterpoles of Budapest (Győr, Pécs, Miskolc, Debrecen, Szeged). The remainder 44.7 per cent of the urban population resides in scattered medium-sized and small towns, located at traffic centres and crossing points of different production areas (Fig. 2).

On the basis of the earners' professional structure 15.9 per cent of the towns ( 13 of them) can be qualified as industrial town. But $46 \cdot 3$ per cent of the towns (31 in number) have a miscellaneous profile, although in addition to other sectors industrial earners play in them the most important role. In 37.5 per cent of the Hungarian towns (31 in number) those employed in industry are only of secondary importance.

Our figure makes it clear that most towns of an industrial kind can be found among the medium-sized towns and those with small population number (Fig. 3).

The number of industrial earners per 10,000 inhabitants and the gross value of fixed assets in socialist industry are largest in the towns of the "industrial axis" running parallel to the range of the Hungarian Central Mountains (Fig. 4). 


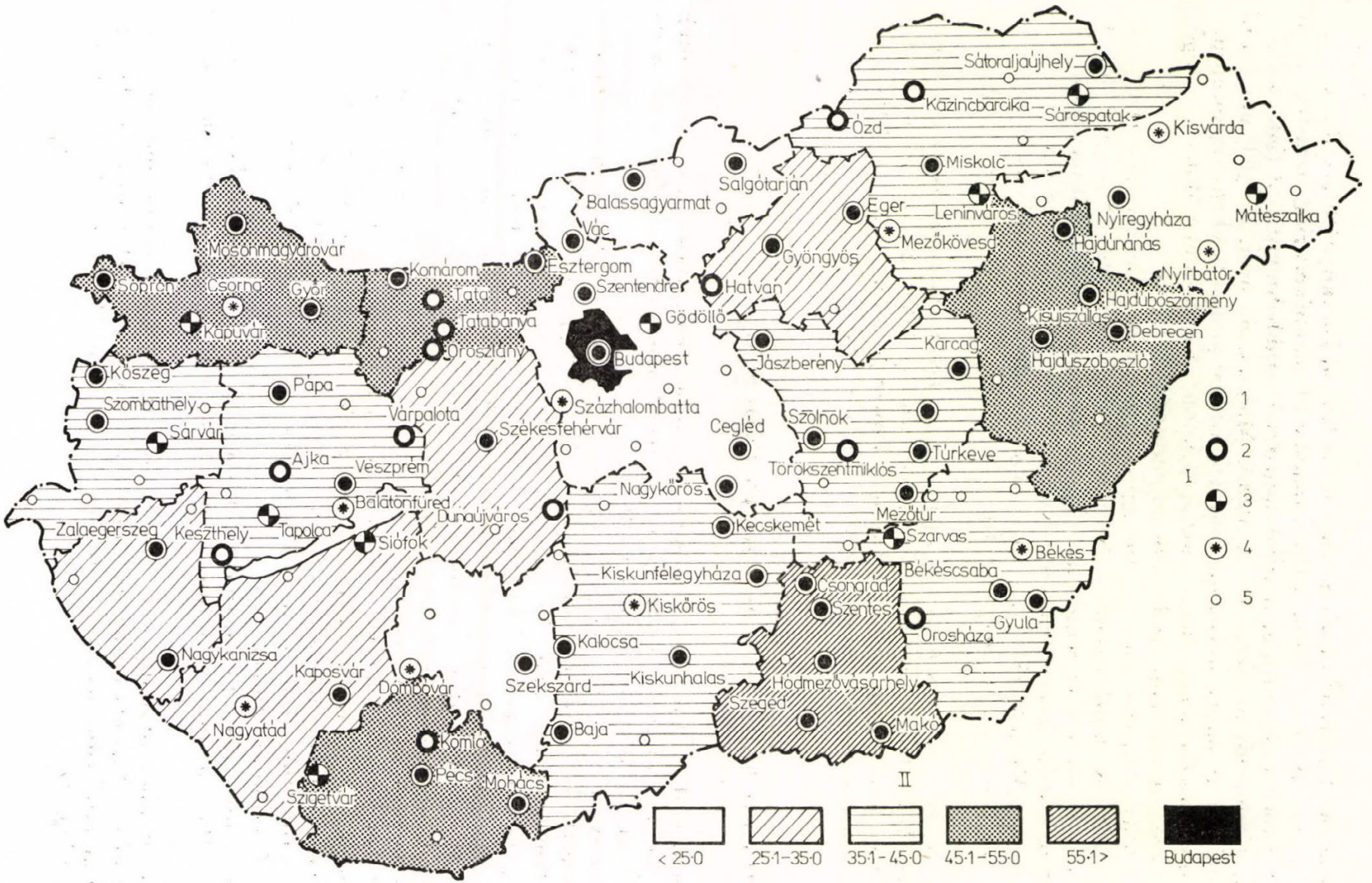

Fig. 2. Hungarian counties and towns on Jan. 1, 1974 - according to the data of the Hungarian Central Statistical Office

I. Number of inhabitants; II. Percentage of urban population 


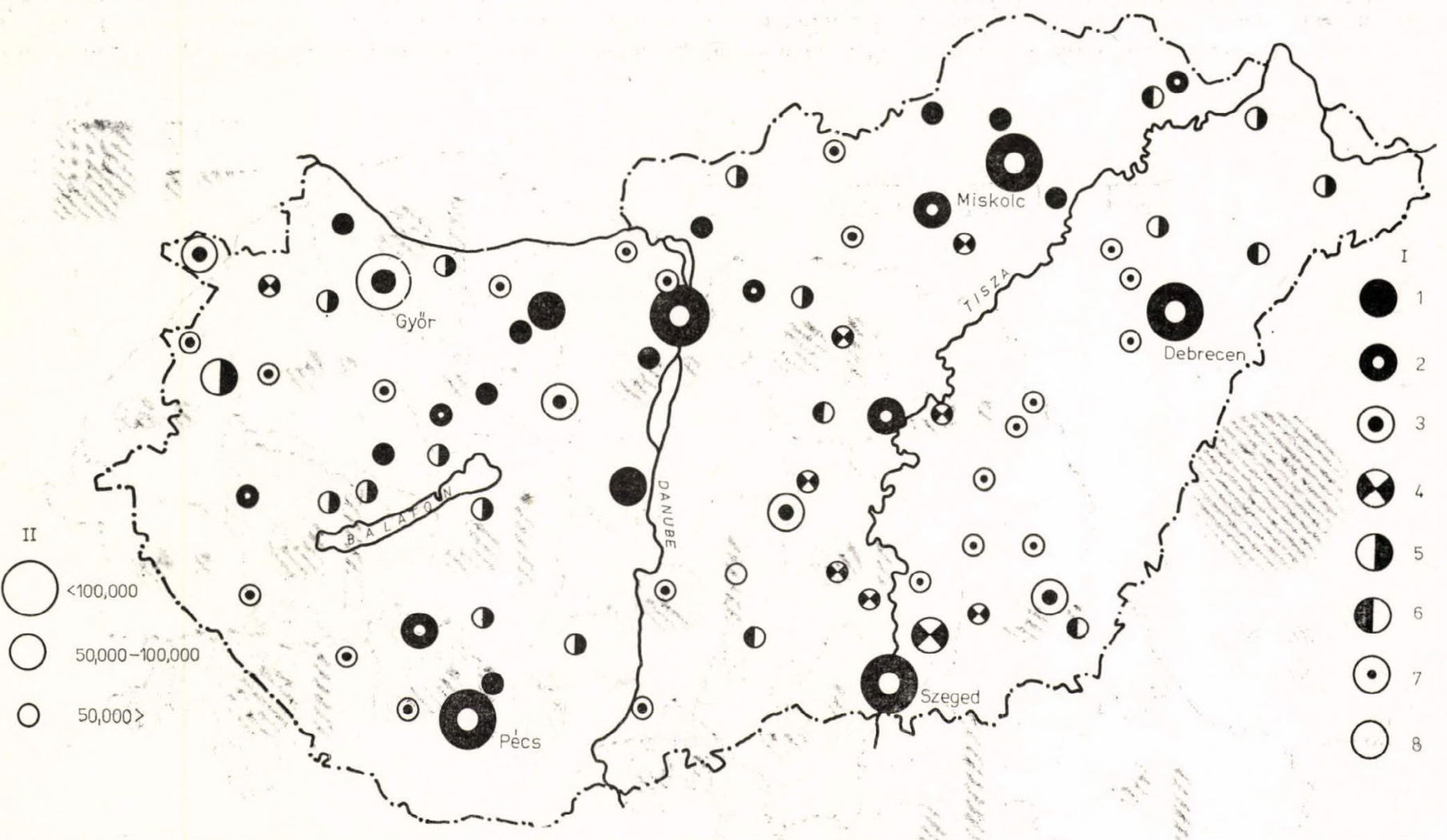

Fig. 3. Types of the Hungarian towns according to their professional character in $1973^{\circ}$

I. Professional character: $1=$ of decisively industrial kind; $2=$ of an industrial-other kind; $3=$ of an industrial-miscellaneous kind; $4=$ of an industrial-agricultural kind; $5=$ of a miscellaneous-industrial lind; $6=$ of a miscellaneous-industrial kind; $7=$ of a 


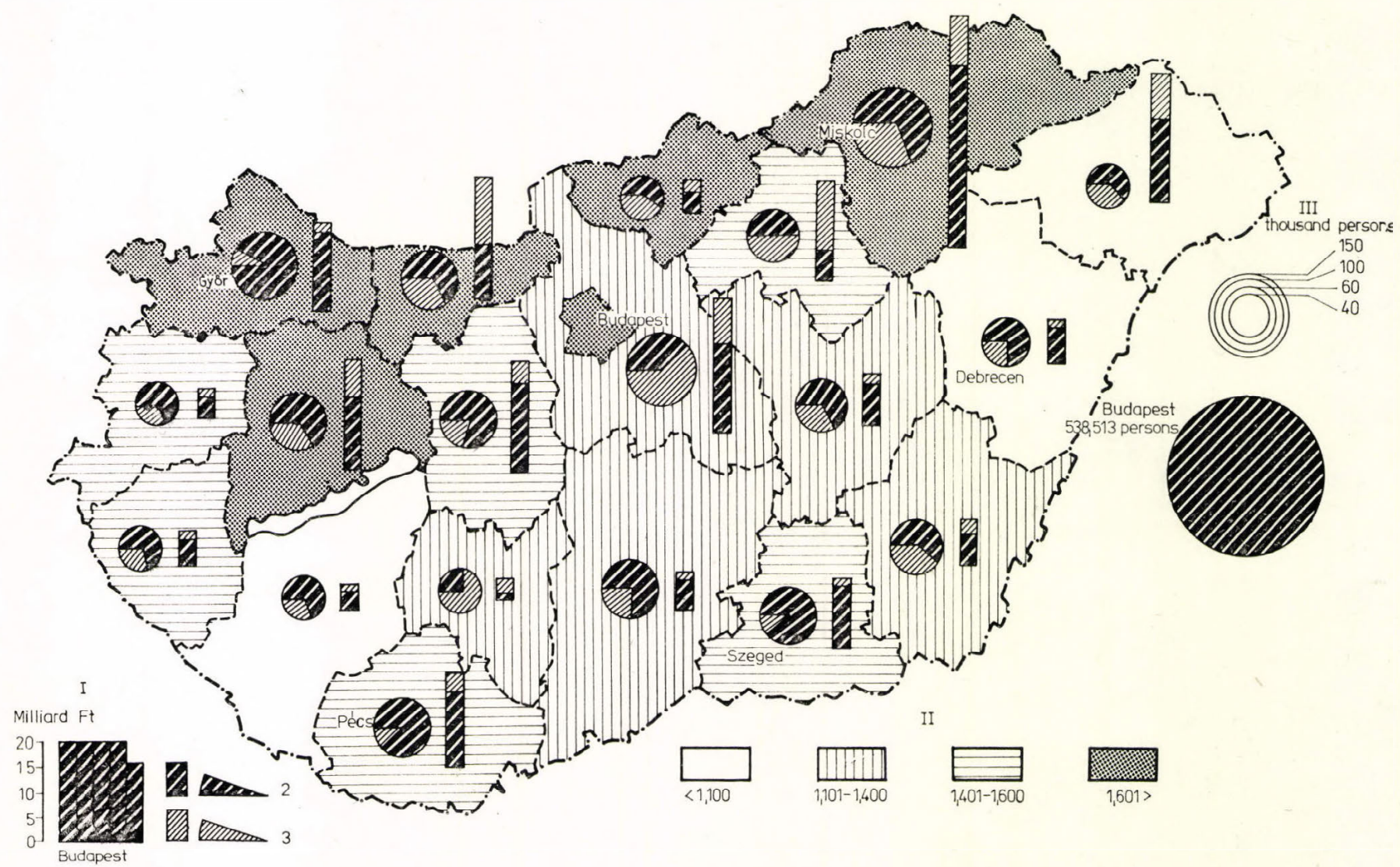

Fig. 4. Regional picture of industrialization in 1975 - according to the data of the Hungarian Central Statistical Office

I. Value of the gross fixed assets in socialist industry in thousand million forints: $1=$ Budapest; $2=$ that of the towns; $3=$ that of the villages. II. Number of those employed in industry per 10,000 inhabitants; III. Number of those employed in socialist industry 


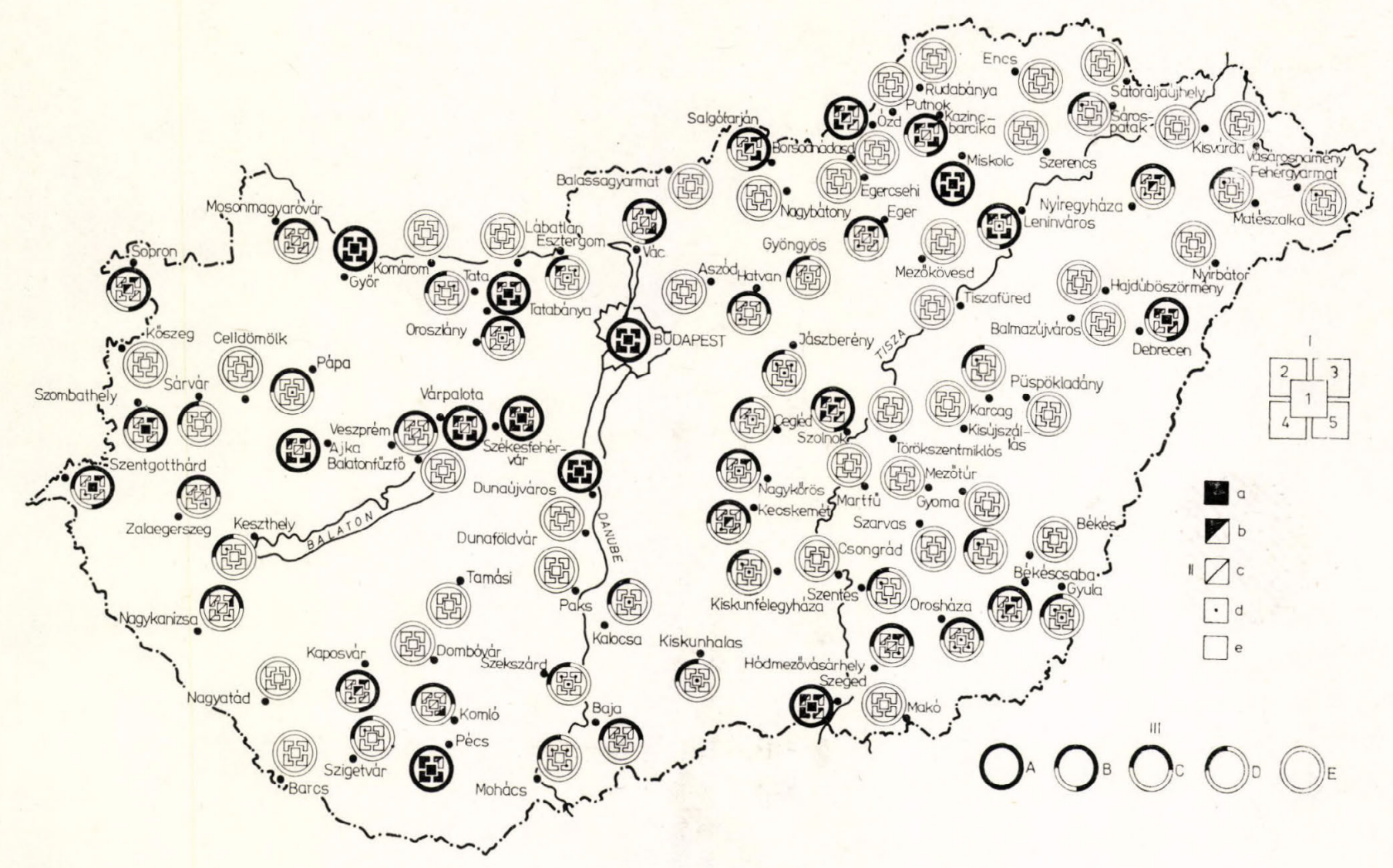

Fig. 5. Conditions of urban industrial production per 10,000 inhabitants

I. Indicators: $1=$ average number of workers; $2=$ size of the gross stock of industrial fixed assets; $3=$ value of machines and equipment; $4=$ size of motive power used; $5=$ specific quantity of electric power used. II. Level of the towns' industrial provision: a $=$ significantly more favorable than the average; $b=$ more favorable than the average; $c=$ average; $d=$ below the average; $e=$ sig-

of nificantly below the average. III. Joint indicator of the towns' industrial provision level: $A=$ considerably higher than the average; $\mathrm{B}=$ higher than the average; $\mathrm{C}=$ average; $\mathrm{D}=$ below the average; $5=$ considerably below the average 


\section{INDUSTRY IN LARGE TOWNS}

Of the stock of Hungary's gross industrial fixed assets $13 \cdot 4$ per cent and of her labour force employed in industry 11.7 per cent have been concentrated in the large towns with great historical background arisen as counterpoles to Budapest (Győr, Pécs, Miskolc, Debreçen, Szeged).

In consequence of previous development processes, greater and smaller differences can be observed relating to size, character and structure of industries in the advantaged higher centers. On the basis of the earners' professional structure Debrecen, Miskolc, Pécs and Szeged belong to the towns of an industrial kind, while Győr can be qualified as a town of an industrial-miscellaneous character (see Figure 3).

The level of industrial provision turns out to be above the average in Gyôr, Pécs and Miskolc, while below the average in Debrecen. Szeged, however, can be qualified as a town disposing of medium-sized industrial potential.

Industry in large towns is broadly based, in which, with few exceptions, all industrial branches can be found. Heavy industry with a high capital equipment dominate the industrial structure of the towns developed in the centre of mineral occurrences (Miskolc, Pécs) or at the crossing points of different production area (Győr). At the same time in addition to heavy industrial branches, light and food industries, too, play an impertant role in the towns situated in agricultural regions (Debrecen, Szeged).

Industrial potential is extremely high in the large towns manufacturing semi-finished (intermediary) goods and finished products and employing upto-date technology as well as skilled labour. From the point of view of per capita production, endowments of the towns of Győr, Miskolc, Pécs and Szeged are well above the average (Fig. 5). Those of Debrecen are also above the average.

Multilateral, dominant settlement factor is typical of all the large towns' industry. Exploitation and processing of energy resources and mineral raw materials occurring in the neighborhood are particular features of Pécs (coal, uranium ore, electric energy production, ceramic industry) and Miskolc (coal, electric energy production, metallurgy of ferrous metals, lime and cement industries). On the other hand, large-scale processing of agricultural products and semi-finished goods can be found in Szeged and Debrecen and, to a lesser

Fig. 6. Long-term (perspective) endowments of the Hungarian towns' industrial development - according to J. Kóródi and Gy. Kőszegfalvi.

I. Factors playing a role in developing: 1 = qualifioations of the labor force; $2=$ opportunities for cooperation within the settlement; $3=$ conditions considering the deposits of the main fuels; $4=$ possibilities of water supply; $5=$ endowments of public services and institutions; $6=$ possibilities of electric energy supply; $7 \doteq$ communications and transport endowments; $8=$ relations to the roads of import-transport; $9=$ conditions considering the domestic consumer market. II. Appraisal of the respective development factors: a $=$ considerably more favorable than the average; $\mathrm{b}=$ more favorable than the average; $\mathrm{c}=$ average; $\mathrm{d}=$ more unfavorable than the average; $\mathrm{e}=$ to a large extent more unfavorable than the average. III. The values of indicators marked with "III" are equal to those in Figure 5 


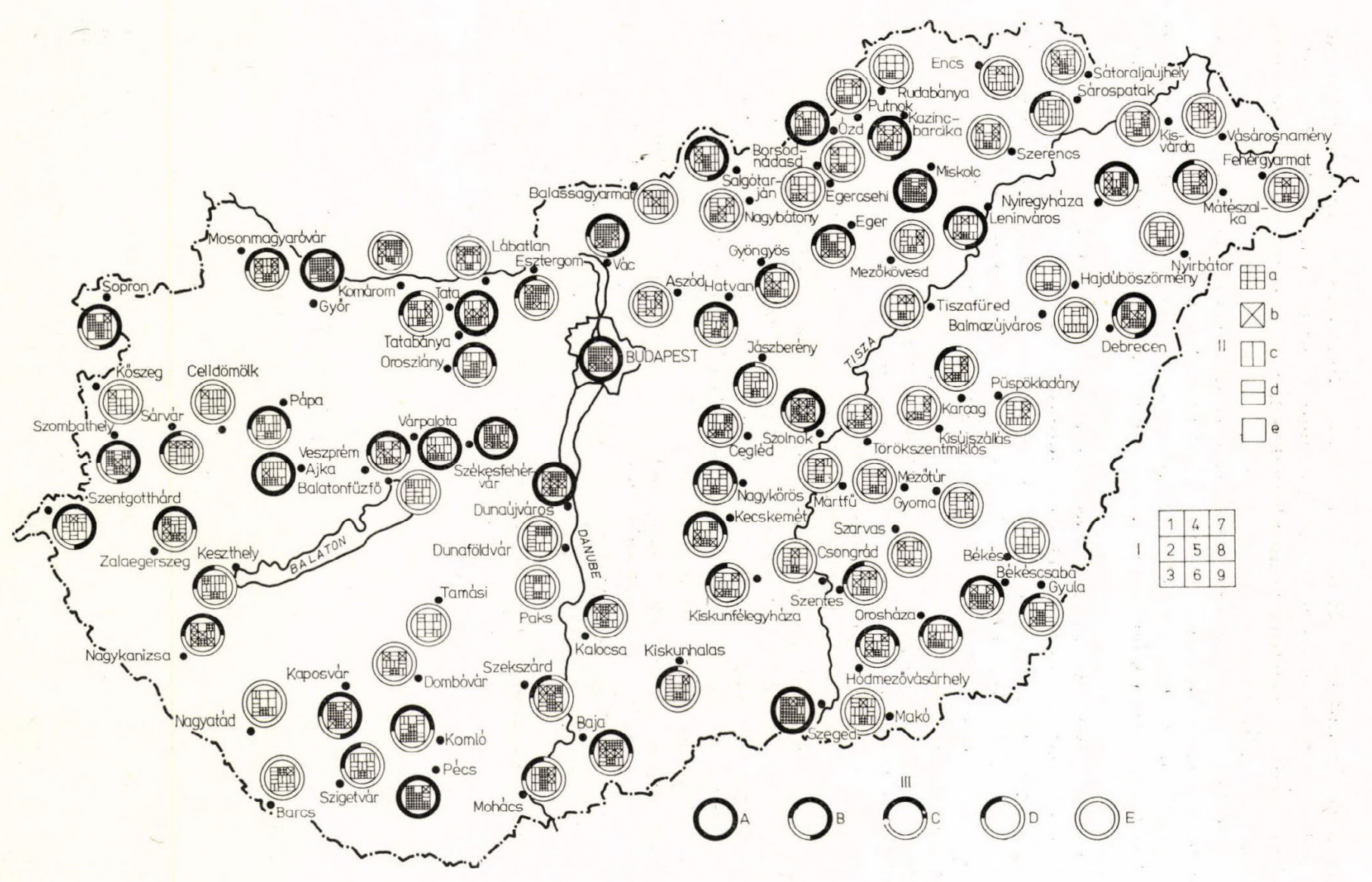


extent, in Győr and Pécs. It is not by chance that flax, hemp and cotton industries have turned into one of the most important branches of light industry in the centers of areas with favourable endowments for plant growing and stock breeding (Győr, Szeged).

The countless advantages deriving from cooperation make up a significant factor in choosing locations for industrial branches manufacturing and processing basic materials as well as various semi-finished goods. High-level infrastructural network both at regional and national level works in the same direction.

In the large towns with considerable industrial potential labour supply represents the greatest problem. Despite intensive employment, local reserves of labour force are being exhausted, though there are enough institutions for training skilled workers (Fig. 6). This may chiefly account for the fact that in some large towns (Györ, Miskole) the share of commuters has been increasing in recent years.

It results from the above situation that the long-term industrial development of large towns depends first of all on possibilities of labour supply. From this point of view the endowments of Debrecen and Pécs seem to be more favourable than those of Miskolc, Szeged, or Győr. Apart from taking into account location conditions of industrial branches sensitive to labour force and infrastructure, it is water resources that are becoming more and more important in course of long-term development. An investigation of the large towns from these aspects has shown that only the endowments of Györ and Szeged are favourable (see Figure 6).

Miskolc and Pécs, well-known for their heavy industrial structure, are situated at the centers of considerable industrial concentrations which is to be preferred due to the industrial structure's transformation needs (Fig. \%).

According to the long-term (perspective) conceptions, the town of Szeged lying on the banks of the river Tisza will be the development center of industries with a high water requirement. Györ and Sopron, however, are part of the concentrated infrastructural development belt, where the location of industrial plants with high cooperation demands seems to be justified.

\section{INDUSTRY IN THE MEDIUM-SIZED TOWNS}

Of Hungary's industrial earners 21.7 per cent and of her stock of industrial fixed assets 22.7 per cent are employed in medium-sized towns developed at advantageous transport centers, chiefly at the crossing points of landscapes with different natural and economic endowments.

Fig. \%. Regional types and means of industrial development - according to J. Kóródi and Gy. Köszegfalvi.

The belt " $\mathrm{A}$ " consists of: 1 = preferred development area, due to the scarce occurrences of natural resources; $2=$ preferred development area due to the transformation of production pattern. The belt " $\mathrm{B}$ " consists of $1=$ development centers of industries with high water requirement; $2=$ development centers of industries with high cooperation (infrastructure) requirement; $3=$ development centers of variable industries. The belt " $\mathrm{C}$ " consists of areas of industrial development of an intensive kind 


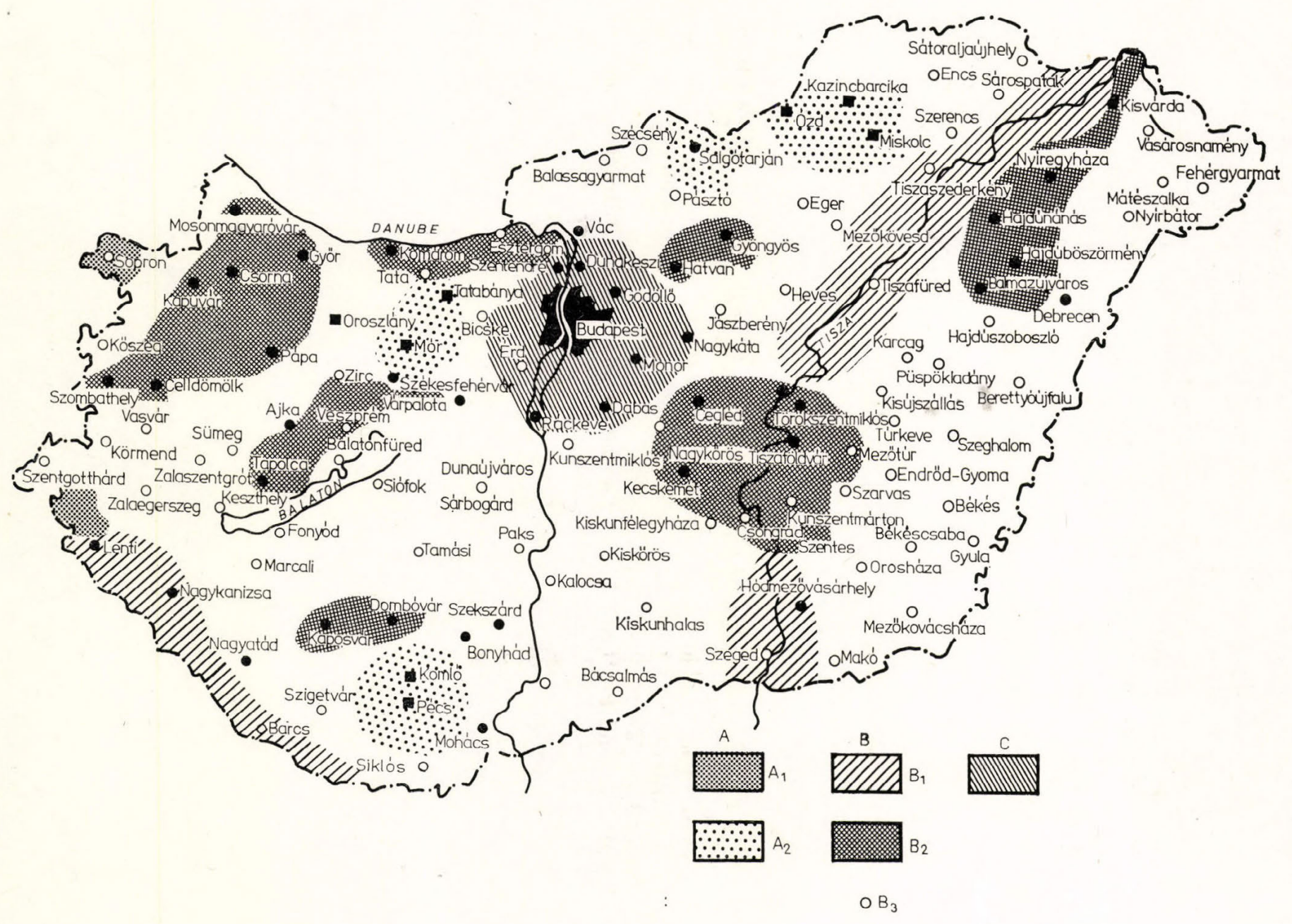


A great part of the Hungarian medium-sized towns excepting only Dunaújváros, Kazincbarcika, Oroszlány, Ózd and Tatabánya, were towns before World War I (see Figure 1) and some of them have got significant historical backgrounds (Eger, Gyöngyös, Kecskemét, Sopron, Székesfehérvár, Szombathely, Vác, Veszprém).

But nowadays the economic function of the medium-sized towns situated in areas processing mineral raw materials and fárming products are determined first of all by the volume and structure of their industrial potential. For the most part this may account for the fact that in many of the mediumsized towns (in 85.7 per cent of them) the number of industrial earners exceeds that of all other professional branches. Their share is lower only in a few towns (Cegléd, Nyíregyháza, Hajdúböszörmény, Szentes).

The Hungarian medium-sized towns $(100,000-30,000$ inhabitants) can be divided into two groups.

a) On the basis of the professional structure 17.8 per cent of them are decisively of an industrial kind, where the share of the industrial earners achieves or exceeds 65 per cent.

The industrial potential of these towns is essentially higher than the national level. From among the towns with heavy industrial structure, Kazincbareika, Tatabánya, and Ozd are located in the vicinity of coal occurrences. From the first mentioned two towns, at Kazincbarcika a coal separator, a condensing thermal power plant and a chemical works as well as a building material plant (lime and cement works), while at Ózd à metallurgical combine have been established. On the other hand Tatabánya, the most significant large town of the Northeast-Transdanubian industrial concentration, is known for its coal mining, electric energy production, cement production and aluminium metallurgy.

From the towns with heavy industrial structure located on the river Danube, the following industrial establishments have been put into operation: at Vác a high capacity building material industry (lime and cement works), machine engineering (telecommunication and vacuum engineering, vehicle production, etc.) as well as light industry (textile), while at Dunaújváros a vertically integrated metallurgical combine, several auxiliary establishments (machine building, chemical industry).

It is easy to understand from the above that on the basis of aggregate per capita natural indicators, conditions of industrial production are without exception favourable. It is at Dunaújváros, Tatabánya and Ozd that from this point of view conditions are by far the best.

b) In the professional structure of a great part of the medium-sized towns (in $69 \cdot 7$ per cent of them) industrial earners prevail. However, in these towns considerable differences in industrial potential can be observed.

Namely, industrial potential is above average in Székesfehérvár, Salgótarján and Nagyk anizsa while it is below average in Kecskemét, Kiskunfélegyháza, Gyöngyös, Nyíregyháza, Szentes and Zalaegerszeg, in line with the national average in Békéscsaba, Baja, Hódmezővásárhely, Eger, Jászberény, Kaposvár, Orosháza, Sopron, Szolnok, Szombathely and Veszprém.

In the industrial structure of these towns utilization of natural resources (coal, oil, gas) as well as various mineral raw materials (clay and aggregates) 
can be observed only at Zalaegerszeg (oil processing), at Salgótarján (metallurgy: iron and steel production; building material industry; quarrying; light industry: glass-making), at Székesfehérvár (aluminium processing) as well as at Békésesaba and Orosháza (building material industry: brick, roof tile; light industry: glass-making and fine ceramic industry).

Among the traditional branches, light industry is especially significant in Kaposvár, Pápa, Sopron, Szolnok and Szombathely.

Textile and textile clothing industries with high manpower and infrastructure requirements are the most frequent ones in Pápa, Szombathely, Kaposvár, Zalaegerszeg, Szolnok, Hódmezővásárhely, Veszprém and Baja) but it is only at Szombathely that a leather factory is in operation.

Greater and smaller plants of the shoe industry can be found in almost all medium-sized towns, but wood processing, paper and printing industries are typical of only a few urban industries (Békésesaba, Eger, Sopron, Szombathely).

Nowadays location choice for light industrial plants has been determined by free labour force and its supply as well as by the infrastructural level serving directly or indirectly the interests of production.

As compared to the plants founded at an earlier date, raw materials and semi-finished goods manufactured in the vicinity have played only a secondary role in establishing new plants, due to the fact that a considerable part of their basic material demands are imported.

In the past significant food industrial capacities have been created in centres of farming regions and in the transport centers separating the mountainous districts from the Great Hungarian Plain's agricultural areas. During the present modernization of industrial structure, however, their importance has in most places decreased. In spite of this fact a considerable share can be observed in the industrial structure of some towns (Hódmezôvásárhely, Jászberény, Kiskunfélegyháza, Orosháza). Capital equipment and labour force supply for food industry are also significant at Kecskemét (preserved food industry, poultry processing), Kaposvár (sugar, meat processing, refrigerating and dairy industries), Szolnok (dairy, sugar, meat processing industries), Eger (tobacco factory) and Zalaegerszeg (dairy industry).

Machine engineering is the most dynamic branch of the medium-sized towns. Industrial structure, owing to the fact that the regional distribution of engineering industry which was formerly concentrated in Budapest and the large industrial towns of Győr and Miskolc (general machine building, ship, locomotive, waggon and motor car production, machine tool building, etc.), has changed as a result of expansion in the provinces. Engineering industry has become predominant at Szombathely, Kaposvár, Eger, Gyöngyös, Jászberény and Kiskunfélegyháza, nor it is less important in Szolnok, Baja, Pápa, Veszprém, Sopron and Zalaegerszeg. While on the one hand in part of the so-called traditional towns industrial branches have been introduced, so general industry (Jászberény, Gyöngyös, Zalaegerszeg), machine tool industry (Békéscsaba, Kecskemét) production of agricultural machinery (Szombathely) as well as iron and metal processing (Sopron, Székesfehérvár, Veszprém), on the other hand industries producing modern new products have spread in many places; such as precision engineering and iron and metal mass products 
(Eger, Jászberény, Hódmezővásárhely, Sopron, Veszprém), production of electric machines and appliances (Baja, Eger, Gyöngyös, Kaposvár, Pápa, Szolnok), telecommunication and vacuum engineering (Gyöngyös, Kaposvár, Kecskemét, Székesfehérvár, Szombathely, Zalaegerszeg). In addition to the Car-body and Vehicle Factory "Ikarus" manufacturing buses, the Radio and Television Factory "Videoton" operating near Székesfehérvár has become the centre of the country's electronic computer production.

Beside machine engineering with its modern industrial structure, the capacity of the chemical industry is not very considerable (Zalaegerszeg).

It is thus clear that the optimum population number of the medium-sized towns has created favourable conditions for modernizing industrial structure, establishing cooperation within the settlement framework as well as developing technical and social instruments.

Undoubtedly, it is the industrial development of medium-sized towns that has played a decisive role in establishing proportional spatial industrial structure and eliminating differences in economic and living standards between the various parts of the country.

As for long-term development, medium-sized towns of an industrial kind, representing major industrial potential require only to a limited extent the location of new industrial establishments. In spite of the fact that there are adequate educational institutions ensuring the training of skilled labour (see Figure 6), at present commuters provide an ever increasing share of labour. Local possibilities of labour supply are limited.

In many places, however, large-scale industrial development of towns with labour and lower industrial potential is hampered: a) by the relatively disadvantageous situation of fuel resources (long-distance electric transmission lines, heat and natural gas pipelines), as in the towns of Nagyatád, Sopron, Pápa, Szombathely, Mezőtúr, Hajdúböszörmény, etc.; b) by the relative backwardness of the educational and cultural network providing for skilled labour (Hódmezővásárhely); c) by troubles in water supply (Sopron, Nagykanizsa, Kiskunhalas, Nagykőrös, Kecskemét, Orosháza, Gyöngyös, etc.). Nor are transport conditions everywhere favorable (Eger, Zalaegerszeg, Hajdúszoboszló) (see Figure 6). Longer distances from the consumer market can mainly be observed in regard to the towns of the Great Hungarian Plain (Orosháza, Mezőtúr, Nagykőrös, Kiskunhalas) (see Figure 7).

Because of the high level of agricultural production in the neighbourhood of the medium-sized towns, large-scale industrial development is not desirable everywhere (Hajdúböszörmény, Hódmezővásárhely, Jászberény, Kiskunfélegyháza).

A considerable number of the medium-sized towns interested in industrial development (Kaposvár, Szombathely, Pápa, Veszprém, Cegléd, Kecskemét, Szentes, Szolnok, Gyöngyös, Nyíregyháza, etc.) constitute part of the industrial development belt with a high infrastructure requirement (see Figure 7).

In consequence of the transformation of the production pattern the towns of Salgótarján, Kazincbarcika, Ózd and Tatabánya have become parts of the preferred development belt (see Figure 7). 


\section{INDUSTRY IN THE SMALL TOWNS}

One finds $13 \cdot 8$ per cent of the industrial labour force living in the small towns. Their share in the gross stock of industrial fixed assets amounts to 16 per cent.

Of the small towns developed in the shadow of greater settlements (41.7 per cent, 20 in number) were already towns before World War II, while 58.3 per cent of them were accorded their charters only later. (See Figure 1.)

As a result of their differentiated socio-economic development, considerable differences can be observed in the industrial potential of the small towns. On the basis of aggregate indicators the level of industrial provision in the towns of Ajka, Komló, Leninváros, Mosonmagyaróvár, Oroszlány and Százhalombatta is above the national average (14.3 per cent). All but one (Mosonmagyaróvár) have become towns since World War II. A major part of them are newly built socialist towns.

Industrial provision is at an average level (18.4 per cent) in Hajdúszoboszló, Hatvan, Gödöllő, Kalocsa, Szentendre, Szigetvár, Mohács and Nagyatád. Industrial potential is, however, below the average in thirty three regionally scattered small towns (in $67 \cdot 3$ per cent of them).

On the basis of their professional profile the small towns can be divided into three groups:

1) $14 \cdot 6$ per cent of them are industrial (Ajka, Komló, Leninváros, Mosonmagyaróvár, Oroszlány, Százhalombatta) all but a few situated at the western and eastern ends of the industrial axis. (See Figure 3.)

Exploitation and transformation of mineral raw materials make up an important factor in the structure of these towns (Ajka, Komló, Oroszlány, Várpalota, respectively Leninváros, Mosonmagyaróvár and Százhalombatta).

As to the unplanned industrial structure of the mining towns located near coal occurrences, only the energy industry (Ajka, Oroszlány, Várpalota) and building material industry (Komló) are worth mentioning. An exception is the town of Várpalota, where chemical industry, machine engineering and aluminium metallurgy also play an important role.

The industry of the newly founded towns with a heavy industrial structure (Leninváros, Százhalombatta) is based on the transformation of liquid and gaseous energy resources (oil processing) and the further utilization of their finished products (electric energy production, artificial fertilizer production, ethylene and propylene production).

Per capita industrial production is much more favourable than the national average. This also holds for the town of Mosonmagyaróvár with its varying industrial structure (iron and metal processing, alumina production, machine engineering, etc.).

2) Besides other sectors, industry has become the dominating branch $(31 \cdot 2$ per cent) in 15 small towns.

Towns of an industrial-miscellaneous kind can often be found in economically developed regions and belts (Esztergom, Kalocsa, Köszeg, Nagyatád, Sárvár, Szentendre, Tata), meanwhile those of an industrial-agricultural kind in areas known for their agricultural production (Csongrád, Kaposvár, Nagy. kőrös, Mezőkövesd, Törökszentmiklós). (See Figure 3.) 
From the industries of these towns with a miscellaneous profile, the food industry (Kaloesa, Nagykőrös, Mezőkövesd, Sárvár, Sátoraljaújhely), light industry (Tata, Csongrád) and machine engineering (Esztergom, Gödöllö, Törökszentmiklós) are the most significant ones.

In some towns (Esztergoni, Kaposvár, Nagyatád, Szekszárd, etc.) several plants belonging to different industrial branches (engineering, food processing, light industry) have also been operating.

Per capita industrial production is more favourable than the average at the towns of Cegléd, Kaposvár, Kalocsa, Kőszeg, Nagyatád, Sátoraljaújhely, Szigetvár, Makó and Tata. The endowments of towns not enumerated can without exception be qualified as average.

In regard to size and structure of their industrial potential, the small towns differ.

The heavy industrial structure of the towns of an industrial kind requires some corrections in consequence of the reduction of production targets for coal mining. As a result of the one-sided industrial structure, their participation within settlement framework is modest (Komló, Oroszlány, Százhalombatta). Their labour reserves have for the most part been exhausted and many of their industrial earners commute to work from surrounding areas. Their water supplies are limited (Ajka, Komló, Oroszlány, Mosonmagyaróvár) (see Figure 6), but earnings and living possibilities are above the national level. The newly built socialist towns are up-to-date as size and level of technical and social infrastructure.

After what has been said it is easy to understand that further increasing the potential of industrial towns cannot be recommended. In order to create a modern, dynamically developing industry it has become necessary to establish a structure which, in addition to locating new plants, reduces the existing production targets of unprofitable industrial branches. All this will be coupled with labour force regrouping and with workers' training for new occupations.

Development possibilities of towns with a miscellaneous profile, being quickly industrialized, are extremely differentiated.

Labour qualifications and supply possibilities are more favourable in Transdanubia (Esztergom, Kőszeg, Tata, Szombathely) than in the Great Hungarian Plain (Nagykörös, Törökszentmiklós, Csongrád, etc.). In order to eliminate this drawback in the last mentioned towns, major educational and cultural developments seem to be desirable. (See Figure 6.)

Owing to the small volume of industrial potential and to the one-sided industrial structure, participation within the settlement framework can be qualified as much more favourable than the average only at Esztergom, Gödöllő and Szentendre. (See Figure 6.)

Industrial water supply seems to be satisfactory only in towns of the banks of the rivers Danube (Esztergom, Szentendre, Kalocsa) and Tisza (Csongrád). With few exceptions their situation is unfavourable with regard to fuel sources as well. Nevertheless they'must continue to develop their industry in view of the fact that the agricultural labour force released from surrounding agricultural areas, moves toward the overcrowded large towns. In addition to creating working possibilities we have to pay particular attention to developing an nfrastructure adequate for the improvement of living conditions. 
In the third group of small towns, industry is of secondary importance. There are plenty of towns in the Great Hungarian Plain with a miscellaneousagricultural profile (Békés, Hatvan, Kareag, Hajdúnánás, Gyula, Szarvas, Makó, etc.). Some other small towns, however, have become characteristic centers of recreation and tourism (Balatonfüred, Hajdúszoboszló, Keszthely Siófok).

Major industrialization of towns forming an integral part of their agricultural surroundings cannot be approved. The situation is similar in recreational areas of abundant natural beauty, where their new functional sphere of action (hotels, sanatoria, spas, etc.) would hardly be reconciled with industrial activities damaging their environment. 


\title{
SELECTIVE INDUSTRIALIZATION AND DISPERSAL OF FACTORIES FROM BUDAPEST: THEIR INFLUENCE ON THE GROWTH OF THE AGGLOMERATION
}

By

\author{
ZOLTÁN TATAI
}

\section{THE DEVELOPMENT OF INDUSTRY IN CAPITAL}

From the second half of the last century up to the Second World War, Budapest belonged - primarily due to the considerable immigration - to European towns with a rapidly growing population. In this period between 1870 and 1943 its population increased fivefold. Following the rise in the population of Budapest likewise the surrounding settlements gained an impetus, too. Budapest is the most populated town of East-Central Europe, one fifth of the total population, and 40 per cent of the urban population is concentrated here.

The primary reason for the concentration of population in the capital was the rapid development of industry. The capital and its environs offered very favourable conditions for the processing industry and much manpower was demanded by the expanding industry. The industry of the Budapest-agglomeration is strongly ramified, thereby providing ample working opportunities for people of different qualifications.

In the last century simultaneously with the rapid industrialization of the other parts of the country the proportion of industry in Budapest decreased within the industry as a whole, but in spite of this fact in 1974 the industry of the capital provided work for 30 per cent of the industrial population of Hungary; here 25 per cent of industrial fixed assets and nearly one third of industrial production of the country are found.

The industry of this agglomeration zone has developed to a greater extent since the end of the third decade of this century; its stock of fixed assets is quite up-to-date and 2.5 per cent of the industrial population is working here. With the fast growth of the Budapest-agglomeration, and the expansion of industry the infrastructure serving both the population and industry hardly kept abreast. This was especially apparent and of great concern in the areas of housing public utilities and communications.

Unfortunately in Budapest there is insufficient manpower to satisfy the demands of the industrial and tertiary branches. The manpower shortage is considerable in spite of the fact that the number of daily commuters from the agglomeration zone is 100-120,000 besides which the number of workers living in bunkhouses surpasses 50,000. Moreover commuting to Budapest cannot be increased substantially. Due to the manpower shortage the capacities of industry are not fully exploited. Moreover the regional dispersion of industry is a problem, because of the location of many industrial establishments is to be found in the housing estates. These facts also hinder the development of both housing estates and the industrial establishments. Due to the building of factories not conforming to the requirement and measures of

7 Enyedi: Urban 
environmental protection an increasing number of industrial estates have to be reconstructed.

Similarly to other industrial centers, in the area of Budapest the process of agglomeration is quite considerable. In the surrounding 44 settlements, population growth and the increased labour force of industry have an essentially faster pace than the national average.

Budapest and its environs - the biggest settlement-concentration of the country - is quite overdeveloped. The proportionate development of Budapest and its environs and that of other regions of the country must be assured by right economic policies. According to a government decision which fixed the main lines of development in the capital:

- the development of industrial production in the capital can be realized by decreasing manpower, by relocating the branches of industry with a low efficiency and by increasing the productivity at a pace surpassing the average;

- the conditions of intensive industrialization must be assured faster than the average, with special respect to the mechanization of material handling;

- when laying down the conditions of the selective development of industry the development of those branches are to be promoted which can most easily be developed in the given area because of their linkages;

- besides limiting the development of branches and plants utilizing the potentialities of the capital with low efficiency, it is necessary to continue to close obsolete factories having a detrimental effect on the living conditions of the population.

\section{STATE OF INDUSTRY IN BUDAPEST, ITS CONDITIONS FOR GROWTH}

Examining the industry of the region it is remarkable that the industry of Budapest rather then that of the agglomeration zone plays a determining role. Therefore mainly the industry of Budapest will be examined.

In spite of its remarkable development and of the fact that it has kept its leading role, the proportion of the nation's industry in the capital has decreased in the last decade both in the number of employed people (1953: 42.5 per cent; 1973: 32 per cent) and with respect to the fixed assets (1963: 32 per cent; 1973: 26 per cent(.

The industrial development of the capital is promoted - as in the pastby favourable natural, social and economic factors. At the same time new delimiting factors can be observed.

Manposver: the number of industrial workplaces today surpasses already the number of employed persons. In the following 15-20 years the number of employed in the industry of Budapest must be reduced by about 100 120,000 taking into account the manpower potentialities of the region, furthermore the growing demand for manpower by the tertiary branch. Moreover further difficulties have arisen not only on account of the manpower shortage but by the fact that there are not enough persons undertaking heavy 
physical work, night shifts or working in plants with a high ambient temperature.

Industrial territories: in the capital the industrial regions, or zones available from earlier times and the new zones allocated for industry are practically all occupied already and the marking out of new industrial zones is very limited. The older industrial establishments - as their surroundings are already built-up - have no possibilities for expansion.

Infrastructure: the infrastructure reserves of the capital are exhausted; their expansion demands tremendous input.

Building capacities: the realization of increasing investment - mainly in the infrastructure - is an ever growing burden or problem for the building industry.

Metropolitan ensironment: in the last decade a growing demand has arisen to protect the environment from the harmful effects of noise, chemicals, etc. To supplement protection which was neglected in the past, further development demands considerable input which may result in lowering the efficiency of the economy.

In spite of the factors limiting development the production of metropolitan industry must be raised in the long run, too. This can only be ensured by an intensive selective development of the industry in Budapest.

The intensive development of industry in Budapest means that the expansion of production is ensured entirely by modernizing the technological processes, speeding-up mechanization, and by improving the methods of work, plant organization and management.

\section{PRINCIPLES OF THE SELECTIVE DEVELOPMENT OF} INDUSTRY IN THE CAPITAL

Under the selective development of Budapest industry the selective industrial policy of the country is realized generally. In addition, the role of the capital in the country, the natural, economic and social conditions deviating from the national ones, are considered the favourable potentialities for industrial production. Shortages and limiting factors are also taken into account as well as the favourable conditions in other parts of the country which can be utilized in industrialization.

From the above it follows that on the one hand the limiting factors already described - manpower, space, infrastructure, demand for building, environmental protection, the dispersal of industrial activities not bound to Budapest - and on the other hand the liquidation of uneconomic production - so releasing manpower and regrouping it to more rapidly developing branches are the principles of selective development to be implemented.

The selective development cannot be applied to the whole industry, but to the individual plants, activities and products. By applying these principles to any actual situation one can decide wich plants, activities and products must be developed, removed to the country, or liquidated.

In the capital about three quarters of the industrial working force is employed by the engineering and light industry. The efficiency of selective 
development of metropolitan industry depends decisively upon the right development of the two leading branches of industry, almost one third of the employed work in the light industry but this proportion is gradually decreasing.

In those branches of light industry which can utilize the special potentialities of the Capital to a lesser degree - shoe and ready-made clothes, furniture-, paper processing industry - and which have a good producing basis elsewhere in the country as well, an essential reduction in the manpower is needed. Under proper direction reduction in the number of working places can be attained so that at the same time the right utilization of workplaces supplied with up-to-date equipment can be ensured.

The engineering industry is the most rapidly developing branch of industry of the Capital, but the participation of Budapest in the engineering industry of the country is considerably reduced - owing to its faster growth elsewhere.

In one part of engineering the demand for highly qualified manpower, need for cooperation, collaboration with scientific development and design institutes, commercial connections, the capital assets of the plants justify the ties with the Capital for assuring development conditions. At the same time in the big enterprises - taking into consideration the overcrowding, the obsolete means of production, technology and products - the abandonment of uneconomic activities, the reshaping of the structure of production is to be carried out and should be accompanied by reconstruction of obsolete buildings, providing modern working conditions and a drastic reduction in the number employed.

There are plants which have got in the way of development of the town, and their closure is unavoidable in the interest of the building of the capital. Obsolete factories enclosed by housing estates and which can be reconstructed only with huge investments should be terminated, too. It is expedient to remove these works to the country, if they are not tied unconditionally to Budapest.

\section{INDUSTRY OF THE AGGLOMERATION ZONE}

The structure and character of industry in the settlements of the agglomeration zone are very different. The industry of this region consists partly of big enterprises of a national character, partly of works of local character. The big enterprises dispose of very considerable fixed assets, they produce goods of decisive importance and therefore one must reckon with their further development.

But it must be kept in mind that the industry of the agglomeration zone and of Budapest draws from the same manpower resource. As in the industry of the agglomeration zone the number of employed will be higher than planned, the number of persons which can be employed in the industry of the capital will decrease essentially to the same degree. Infrastructure improved in the zone irrespective of the importance of industry located in the various settlements.

To ensure an adequate manpower supply for the industry of the Budapest agglomeration it is necessary to limit the foundation of new works producing 
national commodity stocks, the establishment of premises of big enterprises already located in the capital, and the expansion of existing works by increasing manpower. Local enterprises, as well as industrial and agricultural cooperatives and other enterprises having poor, obsolete assets, not satisfying local demands should be limited or closed.

This refers also to the commuting belt beyond the agglomeration zone.

Because of increase in demand, the works producing for the daily consumption of the zone must be developed, primarily the food industry (bakingand dairy industry), and the networks supplying industrial services expanded.

The selective development of metropolitan industry can successfully be realized by coordinated utilization of different methods. Selective development consists also of the cessation of activities such as production of uneconomic articles in the capital - if it does not contradict other important interests of the national economy. The principles of selective development can be and must be realized of through credit policy, location of state investment, subventions to enterprises, examining the space demand of enterprises and by the other activities of industrial policy.

One important method of realizing the selective industrial policy is the dispersal of industry from the capital to the country.

\section{SOME ASPECTS OF DISPERSING FACTORIES FROM THE CAPITAL}

The problems arising from the removal of metropolitan works to the country can only be examined and evaluated suitably as a part of the development of metropolitan industry in the context of national targets for regional development.

\section{Forms of factory dispersal}

Industrial activities may be removed from the capital to the country essentially by two methods: dispersal of plants or ranges of manufacture.

\section{1) Dispersal of factories}

Individual plants were closed in Budapest and their capacities were compensated for by newly established or expanded works in the provinces. The fixed assets of the dispersed works or of those works which were considered for dispersal to the country for other reasons, are much used and are of low technical level. The increased demands with respect to production and the degree of social welfare is poor. It is not desirable to maintain works which are obsolete, providing thereby bad working condition in the capital.

In the new relocated factories the technical level is higher than in the previous ones, and the further expansion of production is ensured. The working conditions are ensured at a suitable level. In the capital the manpower shortage often hampers, even the utilization of existing capacity, but by relocation this problem is eased. 
After overcoming the transitional difficulties connected with removal - such as training new staff and employees - productivity is higher than previously and the costs of production can be lowered. Raising the technical level and extending production can ensure lower costs and rising profits.

In the national economy's interest the closure investment costs incurred are covered by the state. The reestablishment of factories in the country is effected in several ways.

In the capital the closure of the establishments is stipulated by decisions. Carrying out of these tasks in practice comes up against a lot of difficulties partly because of the disinclination of enterprises and authorities to move. In this connection workers, employees and managers are touched also personally. Although in the capital jobs can be found for them because of the manpower shortage, it is a usual phenomenon that workers and employees of such works are not pleased with such changes and try to avoid removal or at least to delay it.

a) In the provinces new plants are erected from central investment and should be of identical or similar size as the previous ones.

b) The building of completely new factories is justified by the increasing production demands, but another factor should be mentioned here: the future development of works in the capital is limited by lack of space, manpower shortage, etc. When fixing the new capacity, the capacity of the works which have been relocated or closed is taken into account, too.

c) Metropolitan enterprises ensure the capacity released in the capital by developing smaller factories or plants taken over from the local authorities. The investments connected with the transference can be realized from the central budget, or as enterprise investment. In the latter case the costs can be covered by the investment fund set up at the enterprise and by bank credit, furthermore by the removal fund made available to the Municipal Council of Budapest.

\section{2) Transferring activities to the country}

Another way of dispersing factories to the country is to relocate certain activities, the production of certain articles from the capital to the country in existing or newly erected plants. This is not generally a central decision, but an enterprise decision. The process goes on because existing plants lack the capacity for further expansion due to shortage or space or manpower, to name just two difficulties. The capacity for further expansion has been utilized well till now by establishing new plants in the provinces or extending the existing plant in the country. In recent years an often applied method of expansion has been the metropolitan enterprises taking over appropriate buildings from local authorities. In this way developments could be realized more quickly and by low asset-input. Transferring the range of manufactured articles does not hamper or endanger the existence and development of the metropolitan enterprises. In fact it even promotes it as the buildings, manpower and other potentialities released can be utilized more advantageously 
by the enterprises and therefore this method is welcomed by them. The costs can be covered by the enterprises in question or from the industrialization fund at the disposal of the local authorities.

\section{The process of factory dispersal}

In the case of factories obliged to relocate, first of all one has to consider the removal of the production equipment. One part unfortunately is the building which cannot be transferred to the country. As to the machines which can be moved, since most are obsolete, it is questionable whether it is economic to dismantle and transport them for re-erection thus maintaining an out-of-date technology. At the same time even considering technical depreciation, it also may happen that the production of certain articles will be possible for a while on these already obsolete machines, too. But it is more important here that the less up-to-date machines can be more appropriate than new plant for training unskilled labour thus preventing unnecessary costs. The production of the works removed to the country in general surpasses the capacity of the previous metropolitan works and along with the machines still usable, there is the possibility for acquiring new and up-to-date machines.

First, as one of the main reasons for dispersal is to release manpower for the works remaining in the capital and further develop employees do not move to the country with the relocated plant. This would not be expedient as these plants have to provide jobs in the new settlement for the inhabitants. At the same time the training of some of the new workers in the old factory is essential before the move to the country while experts have to move to control the investment and the training in the new plants.

Many neglect to take into account the regional regrouping of current assets which is particularly important in the present economic management system, where current assets must be ensured first of all from enterprise resources. The creation of small enterprises and their supply with current assets belong to the least resolved questions and raw materials, the semi-products and manufactured articles and bank deposits are also transferred to the country.

This represents first of all a higher cost in the less investment demanding branches of light industry than removing the machines. Furthermore it is important, that the works to be removed have traditional customers, good market connections and business partners. In the case of setting up a fresh small or medium-sized plant, the building up of outside connections may demand considerable time and material input. In the case of a removal, the organizational apparatus of the unit to be removed which implements the decision cannot be neglected.

Therefore in the economics of a relocation, the replacement of machines is not fundamental, but here the "cradle role" played by the metropolitan enterprise is very important, as is the fact that building space and manpower released. Thereby a possibility is given in the capital to use manpower more efficiently. Question may be raised here whether it would not be more suitable instead of transferring to decide the question more simply by closing down the plants in the capital and creating new ones in the country. 
In cases when there is no longer any need for the product manufactured in the works to be removed, it is expedient to close down the obsolete plant in the capital without removing it to the country. If the product of the metropolitan factory is to be manufactured somewhere else, relocation is right. Under present circumstances the organizational frames, the industrial experience and the regions of production will be regronped by relocating medium-size factories. Removal is accompanied by several advantages which would be otherwise lost. One part of the fixed and current assets would be lost, in the case of closure without removal, and at the same time to develop an independently created enterprise in the country without preliminaries, would result in considerable additional charges. It is true too that the removal may result in organizational and technological rigidness but these dangers are smaller than the advantages obtained by the removal.

The acceleration of the transference was ensured by the setting up of an industrial relocation fund. Between 1968 and 1970 the relocation fund was 250 million forints (Hungarian currency, in mid-March 1, 1976 US \$ was 21.73 forint) and under the 4th five year plan 700 million forints. Relocation and the industrialization of the countryside is done in collaboration. Plants transferring from the capital to the country go mostly to less industrialized zones and to coal mine districts and there promote the process of industrialization, and the reshaping of the industrial structure respectively. At the same time the removal activity is helped by the fact that the local authorities support the process from their own industrial development funds.

\section{Results of relocation}

Relocation promoted the selective development of metropolitan industry and will continue to contribute to it in the future. Such branches and works were transferred to the country, which are not bound to the capital because their demand for skilled labour is not particularly high and they can develop even in less industrialized territories (Fig. 1).

Relocation of the industry of Budapest contributed to the creation of new works in the country, mainly in less industrialized regions while earlier erected factories have expanded further. In the provinces where new plants are created generally at a suitable distance from housing estates in industrial zones where further expansion, generally does not come up against difficulties. The new establishments created in the country allow the use of up-to-date technology and its continuous development and if occasionally obsolete machinery is again used, the machine pool and technology due to new acquisitions is generally more developed than the previous. New factories are created by taking into consideration modern work and social requirements.

Relocation has proved successful inasmuch as it increased the efficiency of metropolitan manpower. At the same time in the provinces, with regard to the fact, that new workplaces are created mainly in the neighbourhood of dwelling-places, the productivity of provincial workers and employees also rises, owing to less time spent on travel and higher technical level of the new factories. Relocation reduces inmigration of the capital and thereby the demand for infrastructure investment in connection with the supply of the 


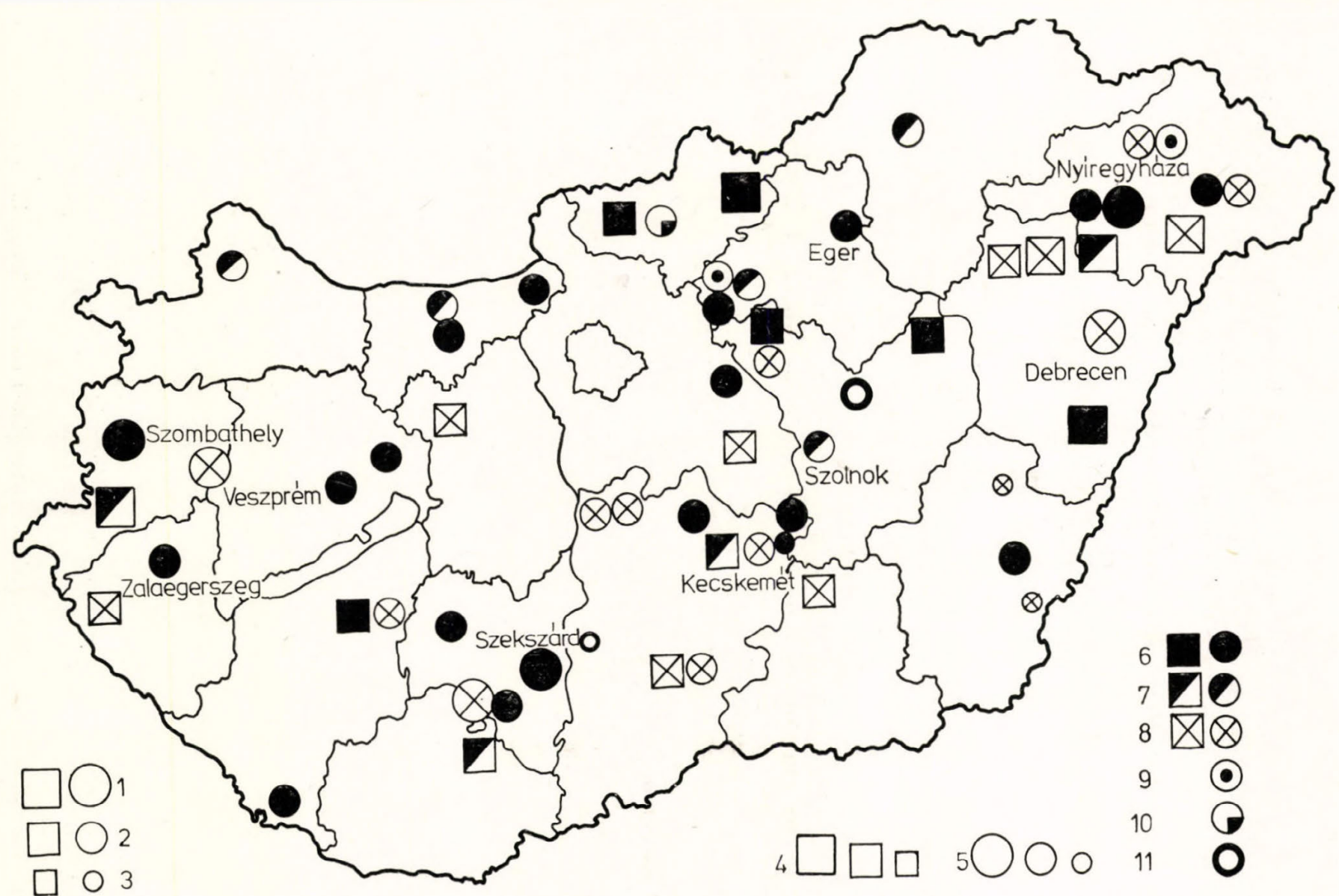

Fig. 1. Improvements in connection with the provincial relocation of factories from Budapest, promoted from the resettlement fund 운 of Budapest City Council, 1968-1975

$1=$ factories, with more than 500 workers; $2=$ between $100-500$ workers; 3 ! = less than; 100 workers; $4=$ new factories; $5=$ reconstructions; $6=$ engineerin industry; $7=$ chemical industry; $8=$ light industry; $9=$ metallurgy; $10=$ building material industry; $11=$ food industry 


\section{TABLE I}

Change in the number of employees occupied by socialist industry in Budapest by industrial branches (per cent of national total)

\begin{tabular}{l|r|r|r}
\hline \multicolumn{1}{c|}{ Branches of industry } & \multicolumn{1}{c|}{1965} & \multicolumn{1}{c|}{1970} & \multicolumn{1}{c}{1975} \\
\hline Mining & & & \\
Electric energy industry & $1 \cdot 8$ & $3 \cdot 0$ & $3 \cdot 4$ \\
Metallurgy & $31 \cdot 8$ & $26 \cdot 8$ & $24 \cdot 9$ \\
Engineering industry & $31 \cdot 5$ & $25 \cdot 9$ & $23 \cdot 7$ \\
Building material industry & $59 \cdot 4$ & $48 \cdot 9$ & $41 \cdot 5$ \\
Chemical industry & $24 \cdot 4$ & $20 \cdot 6$ & $17 \cdot 0$ \\
Light industry & $55 \cdot 1$ & $41 \cdot 6$ & $36 \cdot 3$ \\
Food industry & $44 \cdot 9$ & $36 \cdot 5$ & $29 \cdot 1$ \\
Other industries & $26 \cdot 1$ & $21 \cdot 2$ & $18 \cdot 3$ \\
& $33 \cdot 4$ & $30 \cdot 6$ & $26 \cdot 1$ \\
\hline Socialist industry together & 40.9 & $34 \cdot 4$ & $29 \cdot 3$
\end{tabular}

\section{TABLE II}

Change in selected indices of Budapest industry (per cent of national total)

\begin{tabular}{l|l|l|l}
\hline & 1965 & 1970 & 1975 \\
\hline Industrial plants & 30.5 & $30 \cdot 0$ & $26 \cdot 1$ \\
Industrial workers in Budapest & & & \\
$\quad$ in the socialist industry & $40 \cdot 9$ & $34 \cdot 4$ & $29 \cdot 3$ \\
All industrial workers & $39 \cdot 2$ & $31 \cdot 6$ & $26 \cdot 0$ \\
Gross industrial fixed assets & $30 \cdot 8$ & $27 \cdot 6$ & $24 \cdot 0$ \\
Electric energy consumption & $23 \cdot 6$ & $19 \cdot 7$ & $17 \cdot 1$ \\
Industrial driving force in Budapest & $24 \cdot 5$ & $21 \cdot 6$ & $18 \cdot 5$
\end{tabular}

\section{TABLE III}

Structural change in socialist industry in Budapest on the basis of number of employees

\begin{tabular}{|c|c|c|c|c|c|c|c|c|c|c|}
\hline & \multicolumn{4}{|c|}{ Per cent (1000 p.) } & \multirow{2}{*}{$\begin{array}{c}1975 / \\
1960 \\
\text { (in per } \\
\text { cent) }\end{array}$} & \multicolumn{4}{|c|}{ Per cent employed in Budapest } & \multirow{2}{*}{$\begin{array}{l}\text { In the } \\
\text { country } \\
1975\end{array}$} \\
\hline & 1960 & 1965 & 1970 & 1975 & & 1960 & 1965 & 1970 & 1975 & \\
\hline Mining & $2 \cdot 7$ & $2 \cdot 8$ & $4 \cdot 3$ & $4 \cdot 2$ & 156 & $0 \cdot 5$ & $0 \cdot 5$ & $0 \cdot 7$ & $0 \cdot 8$ & $7 \cdot 3$ \\
\hline Electric energy & 4 & & & $\mathrm{O}^{-}$ & & & & & & \\
\hline $\begin{array}{l}\text { Industry } \\
\text { Metallurgy }\end{array}$ & $\begin{array}{l}11 \cdot 5 \\
28 \cdot 3\end{array}$ & $\begin{array}{l}12 \cdot 7 \\
28 \cdot 9\end{array}$ & $\begin{array}{r}9.5 \\
25.8\end{array}$ & $9 \cdot 6$ & $\begin{array}{l}83 \\
86\end{array}$ & $\begin{array}{l}2 \cdot 0 \\
5 \cdot 0\end{array}$ & $\begin{array}{l}2 \cdot 1 \\
4 \cdot 7\end{array}$ & $\begin{array}{r}1 \cdot 6 \\
4 \cdot 3\end{array}$ & $\begin{array}{l}1 \cdot 9 \\
4 \cdot 8\end{array}$ & $\begin{array}{l}2 \cdot 2 \\
5 \cdot 9\end{array}$ \\
\hline $\begin{array}{l}\text { Engineering } \\
\text { industry }\end{array}$ & $233 \cdot 1$ & $260 \cdot 4$ & $261 \cdot 8$ & $228 \cdot 6$ & 98 & $40 \cdot 8$ & $42 \cdot 5$ & $44 \cdot 0$ & $44 \cdot 7$ & $31 \cdot 6$ \\
\hline Building material & $16 \cdot 8$ & $18 \cdot 1$ & $16 \cdot 6$ & 14.0 & 83 & 2.9 & $3 \cdot 0$ & 2.8 & 2.7 & 4.7 \\
\hline Chemical industry & $40 \cdot 0$ & $47 \cdot 3$ & $46 \cdot 1$ & $43 \cdot 1$ & 108 & $\begin{array}{l}2 \cdot 9 \\
7 \cdot 0\end{array}$ & $7 \cdot 7$ & $\begin{array}{l}2 \cdot 0 \\
7 \cdot 7\end{array}$ & $8 \cdot 4$ & $6 \cdot 8$ \\
\hline Light industry & $188 \cdot 8$ & $189 \cdot 3$ & $172 \cdot 6$ & $132 \cdot 7$ & 70 & $33 \cdot 0$ & $30 \cdot 9$ & $29 \cdot 0$ & $26 \cdot 1$ & $26 \cdot 1$ \\
\hline Food industry & $37 \cdot 9$ & $38 \cdot 1$ & $38 \cdot 0$ & $35 \cdot 9$ & 95 & $6 \cdot 6$ & $6 \cdot 2$ & $6 \cdot 4$ & $7 \cdot 0$ & $11 \cdot 3$ \\
\hline Other industries & $12 \cdot 6$ & $14 \cdot 6$ & $21 \cdot 1$ & $18 \cdot 6$ & 148 & $2 \cdot 2$ & $2 \cdot \overline{4}$ & $3 \cdot 5$ & $3 \cdot 6$ & $4 \cdot 1$ \\
\hline $\begin{array}{l}\text { Socialist industry } \\
\text { together }\end{array}$ & $571 \cdot 7$ & $612 \cdot 2$ & $595 \cdot 8$ & $510 \cdot 9$ & 89 & $100 \cdot 0$ & $100 \cdot 0$ & $100 \cdot 0$ & $100 \cdot 0$ & $100 \cdot 0$ \\
\hline
\end{tabular}


population diminishes. This is more costly than the additional charges connected with the resettlement of experts in the country and keeping population at the same site.

All these facts indicate that relocation offers such considerable economic and social advantages that in spite of the slight hindrances it is advisable to continue and even increase it. Relocation of the industry of Budapest is an organic part of town development and of intensive industrialization and at the same time a condition and means of it.

\section{REFERENCES}

Balogh, K. (1976): A Budapesten települt állami ipar szerkezetének föbb jellemzői (Characteristics of the Structure of State-owned Industry, Located in Budapest). Teriuleti Statisztika, 4, 396-412.

Fodor, L. (1976): A termelőerők területi koncentrációja, agglomerációk, Budapest (Regional Concentration of Productive Forces, Agglomerations, Budapest). Akadémiai Kiadó, Budapest.

Tatai, Z. (1973): A területfejlesztési politika célja és eszközrendszere az iparban (The Aims and Implements of Regional Development Policy in Industry). Területi Statisztika, 5, $518-531$.

Tatai, Z. (1976): Az iparfejlesztés és az ipartelepítés a budapesti agglomerációban (Industrial Development and Industrial Location in the Budapest Agglomeration). Területi Statisztika, $1,10-20$.

Magyarország megyéi és párosai (Counties and Towns of Hungary). (eds: Kulesár, V. and Lackó, L.) Kossuth Könyvkiadó, Budapest, 1975. 



\title{
POPULATION REDISTRIBUTION AND MIGRATION POLICY IN THE U.S. URBAN CONTEXT
}

\author{
By \\ GEORGE J. DEMKO
}

In the United States, as in many parts of the world today, there is a great deal of concern and even alarm over the population problem. This concern has been further heightened by the world food crisis, energy shortage and environmental decay, all of which have been attributed, at least in some measure, to demographic trends. This population problem can be divided into two distinct parts (although they are closely interrelated): population growth, which has received the most attention, and distribution, which has more recently come into focus. The distribution of population, or rather its mal-distribution, is related to such processes as migration, urbanization, suburbanization, and regional economic development, and has come to the fore as one of the most pressing problems in the United States today. The focus of this concern has turned to the city and the urbanization-metropolitanization processes that have been dominant over the American landscape since the turn of the Century and particularly since World War II. At the beginning of the Century about 40 per cent of the American population lived in areas defined as urban, whereas, in 1970, 44 per cent of the population lived in cities of over a million population and, 71 per cent lived in cities of more than 100,000 population. It has been projected that about 85 per cent of the population will live in cities of 100,000 or more by the year $2000 .{ }^{1}$ In essence, in contemporary America, population growth is urban growth and thus it is fitting to focus on the processes and problems of the city in order to understand and solve some of the most pressing problems in our society.

The primary concern of this paper is to examine the development of policies regarding population distribution and migration as they have effected urban development in the United States. Most of this discussion will center on indirect or implicit policy measures which have influenced population redistribution. The paper is divided into four parts. The first concerns a definition and elaboration of the term policy, which is essential to provide a framework against which the U.S. policy measures can be evaluated. The second part contains a brief discussion of the major problems involved in the so-called American urban erisis. This list of problems are the targets at which past and present policies have been aimed. Part three of the paper traces the evalua-

1 J. R. Pickard: U. S. Metropolitan Growth and Expansion, 1970-2000, With Population Projections. Commission on Population Growth and the American Future, Research Reports, Vol. 5; Population Distribution and Policy, S. M. Mazie (ed.), Wash., D. C., Government Printing Office, 1972, Appendix Tables. 
tion of their effects in each case. The final section of the paper attempts to evaluate the recent developments in the emergence of policy goals and examines the alternatives available to solve the pressing urban problems.

\section{POLICY DEFINED}

The term policy has become very fashionable, especially in social science and governmental circles. In the popular and scientific literature one reads of the need for a policy or action policies to solve problems of all kinds. One focus of this literature has been population problems and much of the writing has been addressed to the need for and the definition of population policy. It has been variously defined by a great number of individuals, very few of whom have agreed on its precise meaning and component parts. Two recent excellent statements by DRTVER ${ }^{2}$ and BERELSON ${ }^{3}$ have identified many of the difficulties of defining and identifying policy as it relates to population issues.

In its most inclusive sense, population policy is a set of actions, stated or unstated, intended or unintended, by a government (national or local), organization, or interest group which affect population size, growth rate, composition or distribution. All of the variables mentioned relate to urban problems, but the latter is of greatest import. The major components of any policy should include at least five stages: (1) awareness of a problem or set of problems, (2) goal formation (including short and long term goals), (3) goal adoption, (4) the election of instruments or means to achieve the set goals, and (5) an instrument evaluation or monitoring mechanism.

The first stage, problem awareness, may appear to be obvious and simplistic but is of some significance. In this stage the symptoms of the problem are perceived by some individuals and subgroups of the society, who begin to exert pressure, usually on government organs, to solve the growing problem. For example, in the United States the problems of rapid urbanization and megalopolitan size are not recent but rather have been with us for many years. Thus the awareness of the urban crisis can be regarded as a cumulative process which involves the recognition of one urban related problem after another, each becoming increasingly serious and being perceived by more and more individuals and groups through time. One might even suggest that there are thresholds of awareness or problem perception which triggers subsequent action by governments to address themselves to the issues. Clearly, in the American case, this threshold seems to have been reached in the late 1960's and early 1970's (the recent past and the present) when it has been increasingly clear that piecemeal approaches to single problems in the complex set of interrelated urban problems are not sufficient. This has led to the second stage, the stage of goal adoption.

2 E. D. Drrver: Essays on Population Policy. Lexington Books, Lexington, Mass., 1972; pp. $3-13$.

${ }^{3}$ B. Berelson (ed.): Population Policy in Developed Countries. McGraw-Hill, New York. 1974, pp. 1-7. 
In the policy process, goal formation is a critical phase as it requires some knowledge or idea about what it is one wants to achieve. With regard to population distribution and urban centers goal formation requires one to have in mind answers to questions such as: is there an optimum size city?, or what is the optimum system of cities in terms of rank and size?, or what is the optimum pattern of distribution for a given population? These are, of course, very difficult and complex questions, some of which will be discussed later in this paper.

Goal formation requires, in addition, a clear idea of all the existing problems and then interrelationships as well as an understanding of the processes which have brought about the problem. In assessing the myriad of population problems, and urban problems in particular, in almost any society, there will be problems which call for immediate action and amelioration whereas others are incipient and more resistant to rapid change. Thus, there is a need to identify both short and long term goals. Goal formation is, indeed, a very difficult stage in the policy process and one which the U.S. has reached at this point in time.

The goal adoption phase is also difficult, particularly in the U.S. context. Given that a set of goals can be agreed upon and recommended, there remains the problem of who, or what organization adopts them. In the U.S. governmental framework it is not at all clear how a set of goals are adopted inasmuch as the three main branches (executive, legislative, and judicial) often disagree. The problem of overlapping and confused jurisdiction is exemplified by the abortion issue. The executive branch has taken no position on abortion and the legislative branch is split on the issue. The judicial branch, however, by striking down a state government's restriction on abortion, has taken a stand and, at least implicitly, adopted a position (goal) in favor of legal abortion. This particular example calls forth also the problem of the role of local governments (state, county, city ect.) in the process of goal adoption. At the very least, before any of the three main segments of national government proceed to adopting goals, there must be input, some measure of agreement, and coordination from, and with, local government bodies. Thus, the tripartite nature of the federal government, along with all the subdivisions, commissions, departments, committees etc. that they entail, plus all the plethora of local level governments demands communication and coordination; a difficult task at best.

The fourth stage in the policy formation stage, instrument selection is one of the most complex. The range of types and specific instruments available is immense including legal, economic, persuasive, voluntary, involuntary and more. One of the primary tasks is to identify instruments already in force in order to determine how effective each has been and whether there are existing contradictory measures being applied. It is also essential to identify what policy instruments or programmes in force are indirectly affecting population or urban problems. In the U.S. context this includes a myriad of urban welfare programmes such as the federal housing, highway, and other acts which have important repercussions especially on population distribution. This stage also entails decisions regarding costs of policy programmes, responsible agencies and enforcement among others. The selection of the in- 
struments or means to achieve the goals must also be considered within the framework of short and long run outcomes.

The final phase of policy formation is no less important than the others in that it involves a mechanism for monitoring and evaluating the policy instruments. Such a mechanism demands a system of measuring, gathering and analyzing data so as to determine whether each instrument is effective and producing desired results at or near estimated cost levels. The results of this monitoring system are critical in order to allow feedback into the system of policy formation so that either goals can be modified or measures and programmes deleted, added, or modified. This simple yet vital step is all too often ignored by governments with regard to existing programmes or instruments and, as a result, costly, detrimental or useless measures are allowed to continue at high cost to the society.

The description above of an ideal policy formation process is, of course, in large measure utopian in that most bodies of policy are actually evolved quite haphazardly. In the area of population and urbanization, for example, it is often the case that a specific instrument is selected and implemented in order to solve a particular problem. In the U.S. the Federal Housing Acts, in the Netherlands, the migration subsidy scheme, and in the Soviet Union, the family allowance programme are examples of instruments or measures which are aimed at demographic problems in the absence of any overarching set of goals and which have either little impact or negative results in terms of the specific goals sought. Again, it's usually when some threshold of awareness of a set of related problems is achieved in a society (usually called a crisis) that the need for a complete and reasoned policy is perceived and formulated.

In addition to the main stages of policy formation identified above there are two other issues which must be considered. The first of these is the value system (prevailing philosophy in Driver's terms) of a society against which the decisions in each stage are set and which heavily influence policy formation. In societies where traditions of freedom of mobility are deeply ingrained, for example, legal restrictions on migration to specified cities or areas are unlikely to be adopted and, if adopted, likely to be a serious source of discontent as well as ineffective. In more spatial terms, a family allowance programme designed to increase fertility levels may be very effective in one region and totally ineffective in another as a result of strong spatial variations in values held by subgroups of the population. Many of the urban oriented programmes designed to alleviate problems in U.S. cities (model city programmes, racial integration of schools and others) meet with spatially varied success because of similar variations in values held regionally. Thus, the value system backdrop against which policy is formed may be very crucial and must be considered carefully.

The second issue of great importance in identifying and establishing a body of policy is that of other social and economic policies which, though not aimed explicitly at a coherent and interrelated set of problems such as populationurban problems, impinge upon and seriously affect demographic variables and processes. This elusive and complex set of policies and related instruments are often ignored or only lightly considered in most discussions or descriptions of population policy. They are, however, of great importance and, 
with regard to some demographic processes such as suburbanization or migration, for example, may be of primary significance. The Federal Housing Authority loan policy and Federal Housing Acts have been instrumental in accelerating the growth of American suburbs and maintaining their racial character $^{4}$ while Federal agricultural policy measures such as the acreage allotments and price controls have had tremendous impact on rural to urban migration flows. ${ }^{5}$ Similar results are certain to be found in an examination of national and regional health, education, unemployment compensation, and transportation policies and their impact on population concentration and mobility processes.

Given this definition and elaboration of the policy formation process, it is clear that few, if any, nations have a coherent and consistent policy designed to solve population and urban problems within their societies. Most have addressed a smaller, specific subset of such problems usually without regard to the interdependencies among them. Many nations, including the United States, have become aware of the need for a national policy and this has spurred interest in an evaluation of the success or failure of many of the fragmented programmes employed in the past. Before turning attention to the history of such policies in the U.S., let us examine briefly some of the major issues involved in the current population-urban crisis.

\section{POPULATION DISTRIBUTION AND MIGRATION}

\section{PROBLEMS IN THE U.S.}

The list of problems associated with population distribution and migration patterns in the United States is long and includes, not only those of the city, but also serious problems of rural areas and lagging regions. The redistribution-migration trends of past decades have led to a population increasingly concentrated in urban centers. As the industrial-technological revolution became firmly implanted in the United States a number of concentrating forces were initiated and later accelerated by federal policies especially in agriculture. In the rural areas of the country these began a rapid implantation and diffusion of advanced agricultural technology and capital intensive production techniques led to widespread underemployment and unemployment. This situation was further exacerbated in the post World War II period by federal agricultural policies such as acreage controls and commodity price support programmes. ${ }^{6}$ As labor became more productive in agriculture the rural sur-

\footnotetext{
${ }^{4}$ For a discussion of the processes and policies see, Nerr N. Gold: The Mismatch of Jobs and Low-Income People in Metropolitan Areas and its Implications for Central-City Poor. Commission on Population Growth and the American Future, Research Reports, Vol. 5; Population Distribution and Policy, S. M. Mazie (ed.), Wash., D. C., Government Printing Office, 1972, pp. 399-421.

${ }^{5}$ See Carl W. Hale: Impact of Federal Policy and Technological Change on Regional and Urban Planning Problems. Land Economics, February 1971, pp. 24-35.

${ }^{6}$ For a discussion of this process and details of the agricultural policies and their impact see C. W. Hale, op. cit.
} 


\section{TABLE 1}

Increases in labor productivity and outmigration of farm population in the U.S.

\begin{tabular}{|c|c|c|c|c|c|c|}
\hline \multicolumn{4}{|c|}{ Labor productivity in farming } & \multicolumn{3}{|c|}{$\begin{array}{l}\text { Average annual net outmigration } \\
\text { of farm population }\end{array}$} \\
\hline Period & $\begin{array}{l}\text { Corn for } \\
\text { grain }\end{array}$ & Wheat & Cotton & Period & Thousands & Per cent \\
\hline & \multicolumn{2}{|c|}{ (hours per 100 bushels) } & $\begin{array}{c}\text { (hours per } \\
\text { bale) }\end{array}$ & & & \\
\hline & \multicolumn{3}{|c|}{$\begin{array}{l}\text { Man hours per unit of } \\
\text { production }\end{array}$} & & & \\
\hline & & & & $1920-25$ & 666 & $2 \cdot 1$ \\
\hline & & & & $1925-30$ & 593 & $1 \cdot 9$ \\
\hline 1925-29 & 115 & 74 & 286 & $1930-35$ & 58 & $0 \cdot 2$ \\
\hline 1935-39 & 108 & 67 & 209 & $1935-40$ & 708 & $2 \cdot 3$ \\
\hline $1945-49$ & 53 & 34 & 146 & $1940-45$ & $1 \cdot 602$ & $5 \cdot 8$ \\
\hline $1955-59$ & 20 & 17 & 74 & $1945-50$ & 677 & $2 \cdot 8$ \\
\hline $1965-69$ & 7 & 11 & 30 & $1950-55$ & $1 \cdot 115$ & $5 \cdot 4$ \\
\hline \multirow[t]{4}{*}{$1970-72$} & 6 & 9 & 25 & $1955-60$ & 910 & $5 \cdot 2$ \\
\hline & & & & $1960-65$ & 794 & $5 \cdot 7$ \\
\hline & & & & $1965-70$ & 594 & $5 \cdot 5$ \\
\hline & & & & $1970-73$ & 113 & $1 \cdot 2$ \\
\hline
\end{tabular}

Source: Adapted from F. K. HINes et. al.: Social and Economic Characteristics of the Population in Metro and Nonmetro Counties, 1970. U.S. Department of Agriculture, Economic Research Service, Washington, D.C . March, 1975 , p. 2 .

plus labor migrated to the nation's metropolitan centers in droves. Table $I$ displays the agricultural labor productivity and migration trends from the 1920 's to the early 1970 's.

The urban centers of the country were also experiencing significant change as foci for industrial and related service sector growth. With their large market, transport and labor advantages, urban centers became the nodes of industrial growth, a process accelerated by the growing attraction of external economies afforded enterprises in large urban centers. The result was a massive concentration of capital, both public and private in the metropolitan areas which attracted the millions of rural migrants to them. Because migration is a selective process these centers attracted the young, the strong, the skilled and the enterprising segments of the rural population to the new opportunities in the urban-industrial sector of the economy. This selective migration had a detrimental impact on the rural areas as the most able segments of the population were most prone to leave for the city. The result in many areas was the loss of a major portion of the effective labor force and a loss of employment opportunities as enterprises were deterred from locating in such areas.

The metropolitan centers attracted not only massive numbers of able and skilled rural migrants but also large numbers of others who were attracted by the number and quality of public services and welfare benefits available. 
Continued growth and concentration of economic activities and people in the urban centers were enhanced also by federal programmes such as the Highway Finance Act of 1956 which funneled about 28 billion dollars of government capital to local governments on a 90-100 matching basis from 1956 to 1967.7 Thus, the increasing pile-up of people and growth of affluence of a large middle class induced outward expansion of the metropolitan centers through sheer problems of congestion in the core areas and the desire for better housing and more space available on the periphery of the city. This deconcentration or suburbanization process represented a move outward by a predominantly white middle class population who could afford the costs of housing and travel imposed by such a move. Again, this trend was facilitated by federal policies

TABLE II

Incidence of low income* among families with employed civilian male heads, 14-64 years old in metropolitan and nonmetropolitan counties (1969)

\begin{tabular}{|c|c|c|c|c|c|c|c|}
\hline \multirow[t]{2}{*}{ : } & \multicolumn{2}{|c|}{ United States } & \multirow[t]{2}{*}{$\begin{array}{l}\text { North- } \\
\text { east }\end{array}$} & $\begin{array}{l}\text { North } \\
\text { Central }\end{array}$ & \multirow{2}{*}{ West } & \multicolumn{2}{|c|}{ South } \\
\hline & $\begin{array}{l}\text { Per cent } \\
\text { of total } \\
\text { families }\end{array}$ & $\begin{array}{l}\text { Per cent } \\
\text { of } \\
\text { non- } \\
\text { white } \\
\text { families }\end{array}$ & & of total & & $\begin{array}{l}\text { Per cent } \\
\text { of total } \\
\text { families }\end{array}$ & $\begin{array}{c}\text { Per cent } \\
\text { of } \\
\text { non- } \\
\text { white } \\
\text { families }\end{array}$ \\
\hline U.S. Total & $4 \cdot 8$ & $14 \cdot 0$ & $2 \cdot 7$ & $3 \cdot 5$ & $3 \cdot 8$ & $8 \cdot 2$ & $22 \cdot 7$ \\
\hline I. Metropolitan total & $3 \cdot 4$ & $9 \cdot 6$ & $2 \cdot 5$ & $2 \cdot 5$ & $3 \cdot 2$ & $5 \cdot 7$ & $15 \cdot 7$ \\
\hline $\begin{array}{l}\text { A. Greater Metro } \\
(1 \text { million pop. })\end{array}$ & $2 \cdot 8$ & $7 \cdot 2$ & $2 \cdot 6$ & $2 \cdot 3$ & $2 \cdot 8$ & $4 \cdot 1$ & $11 \cdot 0$ \\
\hline 1. Core & $3 \cdot 1$ & $7 \cdot 2$ & $3 \cdot 1$ & $2 \cdot 5$ & 2.9 & $5 \cdot 0$ & $10 \cdot 9$ \\
\hline 2. Fringe & $2 \cdot 1$ & $7 \cdot 6$ & $1 \cdot 7$ & $2 \cdot 0$ & $2 \cdot 2$ & $3 \cdot 0$ & $11 \cdot 4$ \\
\hline $\begin{array}{l}\text { B. Medium Metro } \\
(250,000-999,999)\end{array}$ & $3 \cdot 9$ & $12 \cdot 8$ & $2 \cdot 4$ & $2 \cdot 4$ & $4 \cdot 0$ & $6 \cdot 0$ & $17 \cdot 6$ \\
\hline $\begin{array}{l}\text { C. Lesser Metro } \\
(250,000 \text { pop. })\end{array}$ & $5 \cdot 3$ & $18 \cdot 8$ & $2 \cdot 8$ & $3 \cdot 1$ & $4 \cdot 0$ & $8 \cdot 1$ & $22 \cdot 7$ \\
\hline $\begin{array}{l}\text { II. Nonmetropolitan total } \\
\text { A. Urbanized } \\
\text { (min. of } 20,000)\end{array}$ & $8 \cdot 5$ & $31 \cdot 7$ & $4 \cdot 0$ & $6 \cdot 0$ & $6 \cdot 5$ & $12 \cdot 4$ & $34 \cdot 9$ \\
\hline 1. Adjacent to SMSA & $5 \cdot 3$ & $23 \cdot 0$ & $3 \cdot 4$ & $3 \cdot 4$ & $6 \cdot 4$ & $8 \cdot 6$ & $27 \cdot 4$ \\
\hline $\begin{array}{l}\text { 2. Not adjacent to SMSA } \\
\text { Bess urbanized } \\
(2,500-19,999)\end{array}$ & $6 \cdot 8$ & $26 \cdot 8$ & $5 \cdot 0$ & $4 \cdot 4$ & $5 \cdot 1$ & $9 \cdot 5$ & $31 \cdot 3$ \\
\hline 1. Adjacent to SMSA & $9 \cdot 0$ & $34 \cdot 2$ & $4 \cdot 3$ & $5 \cdot 4$ & $6 \cdot 6$ & $12 \cdot 9$ & $35 \cdot 5$ \\
\hline $\begin{array}{l}\text { 2. Not adjacent to SMSA } \\
\text { C. Totally rural }\end{array}$ & $9 \cdot 9$ & $34 \cdot 7$ & $5 \cdot 0$ & $7 \cdot 3$ & $6 \cdot 5$ & $13 \cdot 7$ & $38 \cdot 3$ \\
\hline 1. Adjacent to SMSA & $12 \cdot 9$ & $38 \cdot 0$ & $6 \cdot 2$ & $8 \cdot 7$ & $6 \cdot 9$ & $15 \cdot 8$ & $38 \cdot 4$ \\
\hline 2. Not adjacent to SMSA & $14 \cdot 0$ & $41 \cdot 0$ & $6 \cdot 1$ & $11 \cdot 9$ & $10 \cdot 2$ & $17 \cdot 7$ & $43 \cdot 7$ \\
\hline
\end{tabular}

Source: Adapted from F. K. HINEs et, al. Social and Economic Characteristics of the Population in Metro and Nonmetro Counties, 1970. U.S. Department of Agriculture, Economic Research Service, Washington, D.C., March 1975 , p. 54.

* Low income families are defined by a Federal Committee and the index varies with number in the family location and age of family members.

7 Ibid., p. 34, and W. R. McGrath: Urban Transport is an Urban Problem. The Traffic Quarterly, July 1967, pp. 309-310. 
such as those of Federal Housing Administration and the Highway Finance Act. The former agency's policy of insuring loans on homes discriminated in favor of white and reasonably reliable applicants (explicitly until 1949 and implicitly after this time). ${ }^{8}$ The latter programme has been heavily biased in favor of interstate highways and urban freeways whereas the support for urban rapid mass transit has been slighted (up to 1969, only $\$ 445$ million had been allocated by the Federal Government for such projects). ${ }^{9}$

The negative consequences of these concentrating and deconcentrating processes are evident in the distribution of poverty in the U.S. which, although found to some extent in all areas, is focused in rural areas and central cores of metropolitan areas. As shown in Table II, the incidence of low income increases with decreasing size of urban and reaches a maximum in totally rural counties removed from any Standard Metropolitan Statistical Area (SMSA). Within the greater metropolitan areas the incidence of poverty is a third greater in central cores than on city peripheries. In all types of urban and nonurban areas and all major regions the incidence of low income among nonwhites is significantly greater than for the total population. In terms of the gross regions

\section{TABLE III}

Dispersion of white and concentration of black population in urban areas (1970)

\begin{tabular}{l|c|c}
\hline \multicolumn{1}{c|}{ Unit } & $\begin{array}{c}\text { Per cent of } \\
\text { central city } \\
\text { population, } \\
\text { black }\end{array}$ & $\begin{array}{c}\text { Per cent of } \\
\text { population } \\
\text { white outside } \\
\text { central city } \\
\text { (but in SMSA) }\end{array}$ \\
\hline U.S. & $23 \cdot 4$ & $93 \cdot 8$ \\
New England & $10 \cdot 7$ & $98 \cdot 6$ \\
Middle Atlantic (coastal) & $23 \cdot 2$ & $98 \cdot 3$ \\
Middle Atlantic (other) & $14 \cdot 2$ & 99.1 \\
East North Central & $20 \cdot 8$ & $97 \cdot 3$ \\
West North Central & $24 \cdot 1$ & $93 \cdot 2$ \\
Del., Md., D.C. & $57 \cdot 0$ & $92 \cdot 0$ \\
Va., N. Carolina & $43 \cdot 0$ & $90 \cdot 9$ \\
Deep South & $35 \cdot 9$ & $79 \cdot 8$ \\
Pacific Northwest & $5 \cdot 1$ & 97.9 \\
Calif. and the Southwest & $15 \cdot 7$ & $92 \cdot 0$ \\
Cities of: & $16 \cdot 0$ & $91 \cdot 8$ \\
3 million or more & $32 \cdot 9$ & $94 \cdot 4$ \\
1-3 million & $20 \cdot 4$ & $95 \cdot 4$ \\
1/2-1 million & $19 \cdot 5$ & $93 \cdot 3$ \\
250,000-500,000 & $11 \cdot 0$ & $94 \cdot 4$ \\
100,000-250,000 & $1 \cdot 3$ & $98 \cdot 4$ \\
less that 100,000 & & \\
& &
\end{tabular}

Source: Adapted from IRENE TAEUHER: The Changing Distribution of Population of the U.S. in the Twentieth Century. Commission on Population Growth and the American Future, Research Reports, Vol. 5; Population Distribution and Policy, S.M. Mazie (ed.), Washington, D.C., Government Printing Office, 1972 , p. 91.

8 For a review of FHA policies see L. Ropwin: Nations and Cities: A Comparison of Strategies for Urban Growth. Houghton Mifflin, Boston, 1970, pp. 236-266.

${ }^{9}$ W. R. McGrath, op. cit., p. 310. 
represented in the table, the southern section of the U.S. stands out as an area of poverty, particularly for nonwhite population.

The dispersal or suburbanization processes within metropolitan regions has created problems associated with racial separation and increasing isolation of central city populations from better housing and employment opportunities. The racial separation problem can be seen clearly in Table III. Clearly the noncentral city population is overwhelmingly white in all regions and all types of metropolitan areas.

The growth of employment opportunities also reflects the growing isolation of the central city and enhanced situation of the suburb. The increased congestion and reduced accessability in the old industrial city cores combined with the new accessability provided by the interstate interchanges and skilled labour availability on the urban periphery attracted both new and old (formerly central city) enterprises to the fringe. Thus, employment opportunities followed the migration of the white, middle class to the suburbs and removed economic opportunities from ready access of the poor and predominantly nonwhite core population. The data displayed in Table IV dramatically illustrate this problem.

\section{TABLE IV}

Employment* $^{\star}$ changes in 39 selected SMSAs, central cities and suburbs (1948-1967)

\begin{tabular}{lc|c|c|c}
\hline & & SMSAs & Central cities & Suburban rings \\
\hline Net increase in & $1948-67$ & $5,151,000$ & 782,000 & $4,369,000$ \\
employment & $1963-67$ & $2,136,000$ & 542,000 & $1,594,000$ \\
\% Distribution & $1948-67$ & 100 & $15 \cdot 1$ & $84 \cdot 9$ \\
of new employment & $1963-67$ & 100 & $24 \cdot 4$ & $74 \cdot 6$
\end{tabular}

Source: N. N. GOLD: The Mismatch of Jobs and Low-Income People in Metropolitan Areas and Its Implications for the Central-City Poor. Commission on Population Growth and the American Future, Research Reports, Vol. 5 ; Population Distribution and Policy, S.M. Mazie (ed.), Washington, D. C., Government Printing Office, 1972 , p. 449.

* Employment in manufacturing, retail and wholesale trade and selected services.

The contrast between growth on the fringe of the city and in the central core in the past few decades has been great. Between 1960 and 1970, the suburban population grew by 33.5 per cent while the central city population remained nearly constant. ${ }^{10}$ Moreover, the loss of fiscal resources in the central city as a result of outmigration of higher income population and economic activity have resulted in severe fiscal problems exacerbated by the political fragmentation which characterizes metropolitan regions. The financial problems are manifested in reduced levels of public services to residents of central cities affecting the quality of education, transport, health and other services.

The continued concentration of people and activities, particularly in large metropolitan areas, has led to another more recently perceived crisis: the

${ }^{10}$ U. S. Bureau of the Census, Current Population Reports. Series P-23, No. 37 June 24, 1971, Table $\mathrm{H}$ and Table 2. 
problem of negative externalities. These negative externalities are manifested in higher production costs, high costs of providing services, increased incidence of crime, a deteriorating environment, and disappearence of amenities such as open space.

The rapid growth and concentration of economic activity in a few large metropolitan areas in a few regions of the country has also drawn attention to disparities in social and economic levels at the regional level. These less developed, backward regions such as Appalachia contain no major metropolitan centers of opportunity and are characterized by lower per capita incomes, high unemployment and out-migration rates. It has been argued rather convincingly that imperfections in the market system will perpetuate past accumulation processes favoring metropolitan areas and prevent regional spread or trickle down effects to these less favored regions. Consequently, it has been argued that government intervention is necessary in order to stimulate growth in these regions. This call for equity has already been recognized by the government and examples of it are found in the growth center strategy and capital grants for infrastructure development in small and medium-size cities within these regions. ${ }^{11}$

The list of problems associated with population redistribution, migration and urbanization in the U.S. described above is not complete. It would be possible to elaborate on each one cited above and add to the list items like housing abandonment in the central city, psychological alienation of the urban dweller and many others. It should also be noted that many of the trends described above have reduced greatly in intensity (rural to urban migration, for example) and many of the policies mentioned have been altered or amended to reduce or eliminate negative effects. In addition, some of the negative effects of large urban centers have not been finally verified by empirical research. There is indeed some evidence that economic returns from both private and public investment in large metropolitan areas are greater than from small and medium-size cities and that, in terms of economic efficiency criteria, no urban center is too large. ${ }^{12}$ Regarding the incidence of poverty, the number of persons in low-income households declined 0.30 per cent from 1959 to 1969.13

Despite the positive nature of the latter comments, there can be no doubt of the seriousness and persistence of the problems associated with urbanization, redistribution and migration in the U.S. Given this background, let us now turn our attention to the federal policy instruments and programmes aimed at many of these problems as well as the evidence for the emergence of a national population policy.

11 For a discussion of the growth center strategy see, N. M. Hansen: Intermediate Size Cities as Growth Centers. Praeger, N. Y., 1971.

12 Korchi Mera: On the Concentration of Urbanization and Economic Efficiency. Economics Department Working Paper, No. 74, International Bank for Reconstruction and Development, March, 1970 (mimeo).

13 F. K. Hines et al.: Social and Economic Characteristics of the Population in Metro and Nonmetro Counties, 1970. Agricultural Economic Report, No. 272, U.S. Department of Agriculture, Wash., D.C., 1975, p. 47. 


\section{THE EVOLUTION OF U.S. URBAN POLICIES}

Although there have been no conscious and direct attempts to limit metropolitan growth and expansion, there have been, since World War II, a series of measures and programmes implemented by the federal government to ameliorate or solve problems of lagging and depressed regions and declining central cities. It is the purpose of this section to trace the evolution of such indirect or implicit programmes, and attempt an assessment of their impact. In addition, the emergence of an awareness or growing consensus regarding the need for a direct, consistent, and coherent policy will be described.

\section{HOUSING POLICIES}

Of all the federal policies which have had some impact on population and urban problems, those related to housing have been most numerous, persistent and controversial. The first housing policy was embedded in the Home Loan Bank System created in 1932 which established a mortgage credit reserve system to reinforce loans made by savings and loan associations. More important was the Federal Housing Administration (FHA) created in 1934 with the purpose of insuring loans on homes made by savings and commercial banks and insurance companies. The FHA, however, focused their activities on middle-income families and single family dwellings in suburban areas. The Housing Act of 1949 established the Housing and Home Finance Agency which was assigned the primary task of coordinating the activities of the other federal housing agencies. Although mainly concerned with new housing (as were the other agencies) the Act also contained an urban redevelopment clause which essentially amounted to a slum clearance programme. Those early programmes were essentially facilitators of suburbanization for urban residents who could afford the move and who qualified as low risk buyers. Although aimed at cities, the latter legislation held little opportunity for low and moderate income urbanities.

Legislation in 1954 broadened the urban redevelopment aspect of the housing programmes in that it provided for improvement of the existing housing stock and nudged the FHA into providing support to moderate income groups in the central city. Additional legislation followed in the early 1960's essentially similar to earlier acts except for some emphasis on low cost public housing. All of the policies mentioned above had little impact on the low income, predominantly nonwhite populations of the central cities.

The focus of the housing programmes between 1962 and 1966 can be judged from the data in Table $V$. Clearly the preponderance of private housing was built in the suburbs, much with FHA insured loans, whereas public housing was overwhelmingly constructed in the central city. The racial separation and isolation of the poor were being reinforced by federal policies. ${ }^{14}$

14 For an interesting discussion of federal housing policies in some detail see L. RodwIN: Nations and Cities: A Comparison of Strategies for Urban Grosth. Houghton Mifflin, Boston, 1970 , pp. $235-251$. 
Federal housing policies took a major turn away from the earlier, narrow focus with the passage of the Demonstration Cities and Metropolitan Development Act of 1966. This act provided for the Model Cities programme and involved black grants to cities for experiments in solving central city blight problems. The money could be used for housing, job training, education, health services or other activities as determined by citizens involved in the area. Although fraught with funding and other difficulties, the programme was noteworthy for its urban orientation and citizen participation dimension.

The expanding concern of the Federal Government for the broader problems of metropolitan areas became evident in the Housing and Urban Development Act of 1968 which created the Development of Housing of Urban De-

\section{TABLE V.}

Percentage of new private and public housing units inside and outside central cities $(1962-1966)$

\begin{tabular}{c|c|c|c|c}
\hline & \multicolumn{2}{|c|}{ Private units } & \multicolumn{2}{c}{ Public units } \\
\cline { 2 - 4 } Year & $\begin{array}{c}\text { Central } \\
\text { cities }\end{array}$ & Suburbs & $\begin{array}{c}\text { Central } \\
\text { cities }\end{array}$ & Suburbs \\
\hline 1962 & 39 & 61 & 79 & 21 \\
1963 & 38 & 62 & 82 & 18 \\
1964 & 37 & 63 & 74 & 26 \\
1965 & 34 & 66 & 70 & 30 \\
1966 & 34 & 66 & 76 & 24 \\
1967 & 33 & 67 & 83 & 17
\end{tabular}

Source: U.S. Bureau of Labor Statistics. Changes in Urban America, BLS Report, No. 353, 1968.

velopment at the cabinet level. This new agency has a broad charge of coordinating all urban programmes in federal agencies, promoting and commissioning research on a broad range of urban related problems. With regard to housing, Sections 235 and 236 of the act provide for sales and rentals of housing, respectively, and make explicit provisions for aid to minorities both in the central cities and the suburbs. ${ }^{15}$

At the end of 1971 the Housing and Urban Development Act of 1970 was passed in order "to provide for the establishment of a national urban growth policy, to encourage and support the proper growth and development of our states, metropolitan areas, cities, counties, and towns with emphasis upon new community and inner city development..."16 Clearly, housing policies and their implementing agencies were giving way to more all-embracing agen-

15 See Nerl N. Gold : The Mismatch of Jobs and Low-Income People in Metropolitan Areas and Its Implications for the Central-City Poor. The Commission on Population Growth and the American Future, Research Reports, Vol. 5; Population Distribution and Policy, S. M. Mazie (ed)., Was., D.C. Government Printing Office, 1972, pp. 467-472.

16 Public Law 91-609, 91st Congress of the United States, H.R. 19436, 31 December, 1970. 
cies (HUD), now viewing urban problems more realistically and taking cognizance of the need for a comprehensive urban policy.

In sum, the federal housing policies have been rather ineffective to date (except in accelerating the growth of white middle class suburbs) primarily because of their magnitude, timing, and fragmentary nature. Their evaluation, however, was important in focusing government attention on urbanmetropolitan problems and on the growing problems of inner city poverty and racial isolation.

\section{REGIONAL DEVELOPMENT POLICIES}

At the other end of the spatial scale, the Federal Government has been active in regional level programmes designed to alleviate problems of depressed and lagging regions. The first such programme agency, the Area Redevelopment Administration (ARA), was created in 1961 within the Department of Commerce. The programme was aimed at reducing unemployment and was armed with about 332 million dollars to make small loans to business in high unemployment areas, grants and loans for construction of public facilities, and provide technical assistance. The funds provided were much too limited and scattered over too many areas.

In 1965 the Public Works and Economic Development Act was passed which renamed the ARA the Economic Development Administration and modified earlier activities. Five regional planning commissions were established (not including the Appalachian Regional Development Commission created separately by law in 1965). The specific programmes were again aimed at areas of high unemployment and low per capita income, although now defined (in addition to the multistate Appalachian region, the included New England, upper Great Lakes, Ozarks, Four Corners Region of the Southwest and the Coastal Plains areas of the Carolinas and Georgia). Generally, a growth center strategy is employed wherein funds are provided to designated urban centers of the regions for infrastructure development, human resource development, and improving access to basic services. These programmes have enjoyed some limited success in reducing unemployment but overall results in terms of effective regional development have been less than spectacular.

\section{TRANSPORTATION POLICIES}

The effects of the federal government's transportation policy have been discussed, in part, in an earlier section. Clearly, the original programme had a significant impact on both the regional concentration processes as well as the intraurban dispersal processes. ${ }^{2}$ Some later measures have been taken

17 For an evaluation of these programmes see, W. Alonso: Problems, Purposes, and Implicit Policies for a National Strategy of Urbanization. Commission on Population Growth and the American Future, Research Reports, Vol. 5; Population Distribution and Policy, S. M. Mazie (ed.). Wash., D. C., Government Printing Office, 1972, pp. 631-647. 
in an attempt to alleviate some of the serious metropolitan access problems. For example, the urban impact amendment of 1962 requires that social effects of highway location be considered and the Urban Mass Transit Act of 1964 is designed to alleviate inner city mobility problems. ${ }^{18}$ The success of these policies has yet to be evaluated.

\section{MIGRATION POLICIES}

The federal government has played almost no direct role with regard to migration. The only programme initiated was a series of labor mobility experiments carried out by the Department of Labor between 1965 and 1969. The projects involved the cooperation of state employment services and contractors in relocating unemployed persons. Over 14,000 workers were relocated and, by most measures, the programme was quite successful.19

\section{OTHER FEDERAL POLICIES}

There are, of course, a host of other federal policies which can be construed as implicit urban-population policies. One very important set includes the federal defense and military spending programmes involving contracts to private industry, military installations, space programme projects, and many others. On a national basis the combined effect of such programmes have profound effect on regional urban employment levels and other processes. In addition, the recently implemented federal revenue sharing programme whereby almost two billion dollars to states and SMSAs must have some significant impact on urban problems. The assessment of this diffusion of funds would be extraordinarily difficult, however, and outside the purview of this paper.

In summary, despite the absence of an identifiable and coherent populationurban policy in the United States, there has been no lack of implicit policies and programmes whose indirect effects on demographic and urban processes have been significant. Although some of these policies have been ineffectual, only moderately successful or even negative, they have provided the nation with experience and have played some role in bringing about an awareness of the importance of a national policy, coherent, and cognizant of the complexity and interrelatedness of the problems to be solved.

${ }^{18}$ See C. W. HaLe, op. cit., p. 25 and p. 35.

19 For details see: U.S. Dept. of Labor, Manpower Administration, Worker Relocation: A Review of U.S. Department of Labor Mobility Demonstration Projects, C. K. Fairchild, E. F. Shelby and Company, Inc., April 1970; also N. M. Harsen: The Case for GovernmentAssisted Migration. Commission on Population Growth and the American Future, Research Reports, Vol. 5; Population Distribution and Policy, S. M. Mazie (ed.), Government Printing Office, Wash., D.C., 1972, pp. 679-695. 
Federal participation in urban and population programmes through the late 1940 's and the 60 's became increasingly more intense in terms of expenditures and magnitude of problems addressed. Gradually, toward the end of the 60's a growing awareness of the need for a comprehensive national urban and population policy began to take shape. In 1967, at the Symposium on National Growth and Its Distribution, sponsored by the Departments of Agriculture, Housing and Urban Development, Health, Education and Welfare, Labor, and Transportation, a number of participants expressed the need to consider the population distribution questions from a national perspective and deplored the faet that the Federal Government had not done so before. ${ }^{20}$ The symposium was remarkable in the sense that at least six cabinet level agencies were simultaneously involved.

A report issued by the National Commission on Urban Problems (Building the American City) issued in 1968 stressed the need for federal policies to be coordinated in order to expedite the solution of urban problems. ${ }^{21}$ In the same year, a private research organization, the Brookings Institution, published a report (Agenda for the Nation), which addressed itself to the need to solve the complex urban problems which it duly identified. ${ }^{22}$ In 1969 , the President's Committee on Urban Housing issued a report ( $A$ Decent Home) which focused on housing as a national problem requiring significant federal attention. ${ }^{23}$ Clearly, the importance of dealing with population and urban problems was identified in these statements although none had gone as far as to call for a national policy to deal with all of them.

A very noteworthy report was issued in 1968 by the Advisory Commission on Intergovernmental Relations entitled Urban and Rural America: Policies for Future Grosth, ${ }^{24}$ which addressed itself to the gamut of national, regional and metropolitan scale urban, demographic and economic trends and problems. It contained specific policy recommendations for each set of problems and more importantly, stressed the need for the immediate establishment of a national policy. ${ }^{25}$ Similar sentiments were expressed at the National Manpower Conference held in Stillwater, Oklahoma in May, 1968. ${ }^{26}$

${ }^{20}$ National Growth and Its Distribution; Proceedings of a Symposium on Communities of Tomorrosw. Departments of Agriculture, Housing and Urban Development, HEW, Commerce, Labor, and Transportation, Wash., D.C., December, 1967.

21 National Commission on Urban Problems, Building the American City, House Document, Nos 91-34, 91st Congress, 1st Session, Government Printing Office, Wash., D.C., 1968.

${ }^{22}$ K. Gordor (ed.): Agenda for the Nation. The Brookings Institution, Wash., D.C. 1968.

${ }^{23}$ President's Committee on Urban Housing, A Decent Home. Government Printing Office, Wash., D.C., 1969.

${ }^{24}$ Advisory Committee on Intergovernmental Relations, Urban and Rural America: Policies for Future Growth. Government Printing Office, Wash., D.C., 1968.

${ }^{25}$ For an excellent discussion of the content and significance of this report as well as others discussed in this paper, see, Lowdon WINGo: Issues in a National Urban Development Strategy for the United States. Urban Studies, Vol. 9, No. 1, February 1972, pp. 2-36.

${ }^{26}$ U.S. Senate, Committee on Government Operations, The Rural to Urban Population Shift: A National Problem. Proceedings of the National Manpower Conference, Sponsored by the Senate Committee on Government Research, the Ford Foundation, and Oklahoma State University, Stillwater, Oklahoma, May 17-18, 1968. 
Within the executive branch of government the approaching threshold of awareness was also becoming apparent as evidenced by the executive order creating the Urban Affairs Council. One of its primary goals was stated to be assisting the president in formulating and implementing a national urban policy. ${ }^{27}$

Further evidence appeared in 1970 that awareness for a national policy was intensifying. The report of the President's National Goals Research Staff (Toxsard Balanced Groxth: Quantity With Quality) emphasized the need for a federal policy concerning population growth and its distribution and included an assessment of a number of possible strategies including the generation of growth in rural areas, the concentration of growth in medium-size and nonmetropolitan centers and a new cities programme. ${ }^{28}$

Also in 1970, White House urban advisor, DanIEL MoynIHAN, went strongly on record in favor of a national urban policy and criticized the multiplicity of federal programmes and grants in force to solve the complex interdependent set of urban problems. ${ }^{29}$

Finally, in 1970, the Commission on Population Growth and the American Future was established by Congress and charged with the responsibility of inquiring into population and related trends in the U.S. to the year 2000 and make recommendations regarding the means to cope with population, environmental, resource and other problems. ${ }^{30}$ The Commission held public hearings, commissioned over a hundred research reports (publishing seven sets of such reports), issued an interim report ${ }^{31}$ and a final report. ${ }^{32}$ The research reports represented a state of the arts collection of material on all aspects of population in the United States and are an invaluable source of data and knowledge. The final report contains summaries of the research reports and, more importantly, contains a large set of sweeping recommendations for action in all areas. Although some segments of the report are somewhat circumspect and some recommendations vague, there is great value in many sections. The Commission and its work may be more important, however, in terms of turning public attention (both citizens and government officials) to the pressing urban and demographic problems of the United States, in fostering an awareness of the delicate interrelationships among the problems, and in galvanizing broad support for the formulation of a national policy.

${ }^{27}$ L. Rodwin, op. cit., p. 264.

28.President's National Goals Research Staff, Tosward Balanced Growth: Quantity With Quality. Government Printing Office, Wash., D. C., 1970.

${ }^{29}$ Daniel P. Moyninan (ed.): Toward a National Urban Policy. Basic Books, New York, 1970, pp. 3-25.

${ }^{30}$ The Commission on Population Growth and the American Future, Population and the American Future. Government Printing Office, Wash., D. C. 1972, p. 185.

${ }^{31}$ An Interim Report to the President and Congress. Congressional Record, S 3460-S 3466, 1971.

32 The Commission on Population Growth and the American Future, Population and the American Future. Government Printing Office, Wash., D.C., 1973. 


\section{CONCLUSIONS}

The discussion above has covered three main areas: an idealized definition of the process, an identification of the major population distribution and urban problems, and a description and evaluation of the major federal policies which have been addressed to these problems. It should be obvious that the problems are serious, growing more serious with time and have been relatively ineffectually dealt with via piecemeal federal policy instruments. These attempts have been uncoordinated, with even negative results in some cases, and rendered even less effective because of the fragmented nature of local metropolitan government. In sum, policy instrument implementation has run ahead of the goal formation process. There are strong signs, however, that the U.S. has fully entered the stage of problem awareness and has arrived at a point where the need for policy goals and a comprehensive, consistent policy is keenly felt.

In many of the government reports mentioned above and in the recent literature the question of national goals has been increasingly discussed. W. Alonso has identified four major goals: 1) national economic efficiency, 2) equity (in spatial terms), 3) environment, and 4) life style. ${ }^{33} \mathrm{~A}$ healthy and safe environment, the choice of a variety of life styles, and a maximally efficient national economy are reasonably definable and clearly acceptable goals. The notion of equity, however, is much less clear. Does it refer to equity among places or people, or both? How is it measured? These are critical questions which must be answered before such a goal can be adopted and implemented.

There is also the question of the compatibility of the simultaneous pursuit of efficiency and equity. The argument often raised is that, in pursuing equity, activities and resources are deflected to smaller, less efficient centers (the externalities argument) and thus national efficiency is not served. It may well be that a trade-off is necessary in this case - that although disperging economic activity may reduce national efficiency in the short-run, the results in the long-run may be equity and even greater efficiency as a consequence of economically stronger and healthier centers in formerly lagging regions. There is no question that much more research is needed in order to answer questions of this nature and others associated with the set of goals mentioned above.

If the question of broader, overall goals remains elusive, the goals at the next lower level should not be too difficult to indentify as they can be aligned with the set of problems identified earlier. In this case, too, there is a pressing need for much research into the individual problems (migration flows, housing availability, racial separation, employment and unemployment etc.). Clearly, one of the overall goals should be a research agenda for the complex of problems

33 W. Alonso: Problems, Purposes, and Implicit Policies for a National Strategy of Urbanization. Commission on Population Growth and the American Future, Research Reports, Vol. 5; Population Distribution and Policy, S. M. Mazie (ed.), Government Printing Office, Wash., D.C., 1972, p. 637. A similar discussion concerning goals can be found in H. W. Richardson: Optimality in City Size, Systems of Cities and Urban Policy: A Sceptic's View. Urban Studies, Vol. 9, No. 1, February 1972, pp. 41-43. 
which is continually coordinated and updated via some type of national research clearinghouse.

The question of coordination is critical also in terms of federal-local government communication regarding all programmes as well as intergovernmental cooperation and coordination at the local level.

\section{POLICY INSTRUMENTS AND INSTRUMENT EVALUATION}

Among the pressing demands of a national policy is the selection and evaluation of specific instruments or means. Among the first tasks should be the careful evaluation of the measures and programmes which have been used or are being used. For example, the manpower relocation experiments of the Department of Labor mentioned earlier merit careful attention and further experimentation. The growth center policy of the regional commissions also must be carefully monitored and evaluated along with the human resource developments projects associated with them. A. R. PRED's suggestion that the small and medium-size centers suffer from low interdependence and low closure should be carefully considered. His recommendation that major jobproviding organizations be induced to locate important management functions and white-collar units in the largest cities of lagging and depressed regions and programs established to train local people for those jobs ${ }^{34}$ may be a very useful addition to the growth center strategy.

Although the notion of optimal city size has become a major issue of discussion, there seem to be too many difficulties associated with it to render it useful in a policy sence. H. W. RiCHARDSON, after arguing effectively against the feasibility of a policy of optimal city-size, raises the interesting notion of minimum city-size which would represent a population level of a city which is required to meet demand for major services and which might imply a threshold beyond which growth becomes self-sustaining ${ }^{35}$ (an urban application of Rostow's take-off concept).

Other policy instruments which merit attention and additional research include the regulation of industrial location, new towns programmes, federal and local tax policies. Perhaps even more important, however, is the need for innovation and imagination to devise new programmes and instruments to solve the growing problems. In this evaluation and modification of programmes and search for new ones, the role of time must be carefully considered. Many of the present problems may not be so much related to the magnitude of rural outmigration or urban immigrations, or to the smallness or largeness of the centers involved, but rather to the rates of flox and change which are too rapid to be handled and absorbed. ${ }^{36}$ And, as Alonso and Richardson point out, many of the specific policies may be best evolved and implemented over

${ }^{34}$ A. R. Pred: Major Job-Providing Organizations and Systems of Cities. Commission on College Geography, Resource Paper, No. 27, Assoc. of American Geographers, Washington, D.C., 1974 , pp. $62-63$.

${ }^{35}$ Harry W. Richardson, op. cit., pp. 29-35.

${ }_{36}$ This point is discussed in a policy framework by Richardson, Ibid., p. 46. 
time as more is learned about the processes involved allowing us to evolve from a programme of problem oriented policies to one of system oriented policies based upon greater knowledge of the interrelated and interdependent nature of the problems. ${ }^{37}$

There can be little doubt that the United States is, indeed, in the midst of a population distribution and urban crisis, but a large portion of that crisis is one of the processes with which we must deal, ignorance regarding the most appropriate solutions to the plethora of complex problems, and, in some cases, cven ignorance of some of the trends and information required to properly identify the problems. In a more positive vein, there is room for optimism in that a threshold of awareness appears to have been achieved and there are clear signs of movement toward the development of a national policy.

37 Ibid., pp. 46-47 and Alonso, op. cit., p. 636. 

Part two

URBAN STRUCTURE AND SERVICES 



\title{
GROWTH MODEL OF THE AGGLOMERATION OF BUDAPEST
}

\author{
By \\ LÁSZLÓ FODOR
}

On the basis of present available data it is very difficult to express the growth model of the agglomeration of Budapest in a mathematical form. We undertook such an experiment in the years 1965-67 elaborating at that time the system of relations existing between industrial growth and the economy of Budapest. In this system we tried to construct a model representing the fundamental branches of production within Budapest as well as their relations to other territories of the country, a model that enables us to investigate the interrelationships between the productive and non-productive spheres within Budapest. We reported the results of our investigations at the 8th European Congress of the Regional Science Association. The documentation referring hereto may be found in the 23rd volume of papers published by the University of Pennsylvania under the title: "Some problems of metropolitan industrial agglomeration, Budapest case". In our present lecture we started from the fact that the above model system is already known and thus we have restricted ourselves to summing up the experiences obtained in the past few years.

It is generally known that literature on growth models of settlements is quite extensive and that for the different growth problems scientists may choose from a wide range of investigation methods. The number of mathematical and verbal models that may be directly used in the solution of exact and practical problems is, however, extremely low. This relates particularly to planning problems, where a relatively large-range of socio-economic factors is necessary to provide a comprehensive programme on the nature of growth of larger concentrations and agglomerations and on medium or long-term development strategies or tactics. Moreover there are determining factors influencing growth which cannot be formulated mathematically or numerically. In addition information relating to theoretically quantifiable relationships cannot be acquired, owing to the inadequacy of prevailing in formation systems in these countries. This applies particularly to Hungary where the measurement of numerous relations connected with production and interdependencies are unsolved and those fundamental data-applying and -elaborating systems which could lead to the construction of an acceptable model system have not been sufficiently developed.

The model system presented in 1968 was based on a single survey of data, which owing to its static character was only suitable for drawing conclusions in a certain restricted sense. To be able to investigate the system of relationships - elucidated on the basis of these models - in their relation to the situation of today, another survey of the data would be necessary. This is, however, not yet possible. Notwithstanding we find that there is a real pos- 
sibility of presenting a verbal model of the growth of the agglomeration of Budapest that may finally serve as the basis of a short-, medium-, longrange developmental concepts. Our method is essentially identical to that of the verbal model of G. MYrDaL, and some of our conclusions are based first of all on logical considerations. According to our opinion, the determination of the nature of growth can only to a small extent, depend on the mechanical, dynamical extrapolation of the tendencies emerging in the last $15-20$ years; further we think that the numerical information available at present, is in itself inadequate.

We proceed from the fact that an agglomeration is generally and concretely not a static but a dynamic category. Namely, we do not agree with the notion, according to which the agglomeration of Budapest consists of Budapest and the 44 settlements surrounding it. This delimitation - in practice serving as a basis of medium- and long-term planning - is already today unsatisfactory and it cannot allow for the concrete expansion and size of the agglomeration of Budapest. It is particularly unsuitable for supporting a long-term program since the scope of the settlements belonging to the agglomeration changes according to development tactics and strategy. It is easy to understand that in the future a great number of settlements will be part of the agglomeration of Budapest that are today not regarded as such and inversely, several settlements will lose their agglomeration character. Consequently, if we wish to construct some sort of a frame to the growth model of the agglomeration of Budapest, we must proceed from the fact that size, expansion and scale are dynamic categories changing in space and time.

The growth model of the agglomeration of Budapest is based on the fundamental question of what sort of relations do we want to develop between Budapest and its environment and the socio-economic potential of the other parts of the country. It is obvious that this relationship is determined by the national, social and economic potential, this latter being the accumulation of all endowments and possibilities that may be employed in the socioeconomic development of our country. It is also evident that this potential - we refer to it in a wider sense than its being only the productive forces is by no means arranged uniformly either in space or in time.

It seems that the present growth period is of a transitional character, taking into consideration that economic growth changes from extensive to intensive development, which at the same time means also a decrease in the rate of expansion of economic potential. This specifying feature of development fundamentally determines the rate and direction of social transformation. This may refer to the spatial location of population, to the transformation of the socio-economic structure of country regions, districts, counties, agglomerations, towns, etc. and on this basis to the structural changes to be expected in the whole country.

It is particularly essential to emphasize that we regard the forthcoming medium-, and long-term growth period as being fundamentally of a transitional character. One may conclude on the probability that both in the economic and social spheres certain tensions will become intensified and that these will disturb the balance. In the economic sphere an essential contradiction may be caused by the intensification of contradictions between produc- 
tive and non-productive sectors, namely by the under-development of the infrastructural background of productive activity. The origin of this can be attributed to the production-centered economic policy of the development period of extensive character. It is obvious that the intensive development of the production sphere leads to a specifically higher infrastructural demand. Therefore it is of principal interest that the branches of infrastructure should be developed at the highest possible rate.

Another fundamental problem of the transitional character lies in the development of relations among the branches of production. Here not only is the relationship between primary and secondary sectors included, for the intensification of tensions within the secondary sector is perhaps even of a greater importance. In the growth period of extensive character a frontal development of the secondary sector (in our opinion of the processing industry) was observable. This resulted in the fact that both at a national scale and in smaller settlements and districts the economic structure changed at a different rate. This particularly related to the agglomeration of Budapest, within the economy of which the secondary sector today still prevails and where the frontal growth led to a certain stiffening of the industrial structure. As a consequence of this in the present transitional period the scope of fundamental branches determining industrial structure and that of the so-called dynamic industrial branches do not coincide. This means that the weight of industrial branches developing today at the highest rate is low within the agglomeration of Budapest (these are electronics, precision engineering, certain branches of the chemical industry etc.) and that the growth of industrial concentration is even today - and for a relatively long time in the coming period - determined by the so-called traditional branches of engineering and light industry. Due to this the growth rate of industry in Budapest considerably lags behind that of industrial growth in the country, reaching one half or two thirds of the latter. This does not mean, of course, that the economic efficiency of industry in Budapest is lower than the one in the country. On the contrary: both the per capita production and the proportional gain of investment of industry in Budapest is higher than the national average. This effects the long-term growth model insofar as the following problem arises: to what extent do we succeed in regrouping and concentrating our development resources in a way that they should accelerate the development of dynamic branches within the secondary sector. We must ensure that the economic structure should show a tendency towards the dynamic branches and that the growth of socio-economic potential should reach the highest possible rate also from this side.

A further problem of the long-term growth model - in relation to the transitional character - is that in the case of the agglomeration of Budapest we must reckon with the contraction of extensive and intensive development sources. The contraction of the sources of extensive character is a well-known and obvious fact. The slowing down of migration processes and the decline of migration to the agglomeration of Budapest relates to two facts: it means on the one hand that the agglomeration of Budapest has lost its capacity to absorb population owing to an insufficient development of population infrastructure. On the other hand: it depends also on the fact that agriculture is today not releasing labour as intensively as before. Further: due to extensive location of 
industry, the local problems of employment became essentially solved and so the population has lost its mobility. Under such conditions, we cannot assume that the growth of socio-economic potential of the agglomeration of Budapest takes place parallel through an increase in the labour force. The calculations carried out so far show that the labour force cannot be expanded - not even in the long run - considerably in the agglomeration of Budapest. Thus the growth of Budapest can only be envisaged if Budapest and its environment become independent as regards labour. In our opinion, the expansion of the labour force calls for fundamental agrarian political provisions based on a faster intensification of agricultural production and on the release of surplus labour from agriculture at a higher rate than planned. If such changes take place in agrarian policy, then parallel to these, the infrastructural network of industrial centres - and of the agglomeration of Budapest - must be developed to such an extent that it is suitable for the influx of labour released from agriculture.

A further peculiarity of the transitional character determining the growth model of the agglomeration is that the secondary sector has lost its population concentrating force. This means in the case of the agglomeration of Budapest that since 1964 the number of employees in industry has actually decreased. In spite of this fact the rate of migration and the migration gain have not changed considerably. As a result, the rate of population concentration shows a rising tendency and year by year an even growing proportion of the population of our country lives in the capital or in its environment. On the basis of the experiences of almost two years it can be stated that the tertiary sector has become the most posverful population concentrating factor. The analysis of the socio-economic structure of the Budapest agglomeration indicates that in relation to other cities and agglomerations of the world the ratio of the tertiary sector within this structure is exceedingly low in Budapest and in Hungary. This causes the disequilibrium that is characteristic of the economy of Budapest in the transitional period. It seems that within the economy of Budapest in the coming long-term period the development of the tertiary sector at a rate higher than the average will become an objective necessity. At present and also in the near future - the development of the tertiary sector demands most of the surplus labour force. The fulfilment of this demand in the present demographic and labour force situation is only possible if the secondary sector releases labour. This makes, however, the intensive and selective development of the branches of production absolutely necessary.

The system of demands - outlined in the preceding - fundamentally concerns our investment and settlement policy. In order to ensure the development of infrastructural branches at a rate higher than the average and the intensive and selective development of the branches of production, the resources with accumulation purpose must be concentrated more intensively than hitherto on the agglomeration of Budapest. In this way, the specifically higher demand of investment into intensive development can be satisfied and both the infrastructural background of the branches of production and the population intake capacity of the Budapest agglomeration can be appropriately increased. 
Thus the growth model of the agglomeration of Budapest presumes on the one hand that the coming long-term period will have a transitional character and that in this period intensive development will become an objective necessity. On the other hand, intensive development must be linked with a sectoral and spatial concentration adequate to intensive development.

From the demographic side, the growth rate of population number will not exceed the present level. The labour force will not expand considerably. Development of the branches of population: the structure of products will be reduced, the proportion of branches developing dynamically within the industrial structure will increase and the gradual change of the structure of industry as well as the rearrangement of intersectoral relations and interdependencies can be expected. With regard to labour force, the secondary sector will become self-supplying and the investments into production will be concentrated more than hitherto on the area of the Budapest agglomeration. In ensuring intensive development this is absolutely necessary and in our opinion it does not mean an increase of the spatial disproportions that have evolved in the country and still exist today. Development of the tertiary sector: both the productive and the so-called population infrastructure will develop at a rate higher than the average and within the total investments the weight of means applied for the development of infrastructure will increase. This will partly lead to the raising of the level of supply and partly to the improvement of the population-intake capacity of the agglomeration.

Beyond the above, the realization of this growth model is only possible if we regard the agglomeration of Budapest as a dynamic category and if we look at the agglomeration as being an independent socio-economic unit. Thus within the Budapest agglomeration, the development of the capital and that of the other settlements belonging to the agglomeration must be treated as a problem showing also spatial dependence. A development policy of administrative separation and thus different in its character cannot be followed and the settlements in the environment of Budapest must be regarded as reserve areas for the development of the capital city. Only in this way can the spatial concentration of the Budapest agglomeration be solved and the most efficient use of the development sources ensured. In the coming long-term period development areas must be created alongside the Budapest agglomeration and can be developed independently from administrative boundaries.

The analysis carried out up to now shows that the spatial structure of the agglomeration enables the formation of four development areas. Of these two - on both sides of the river Danube - secure to the north the linear development of the present radiocentric town structure, while towards the southeast a development axis of smaller capacity can be created. As regards the development axis running towards the east, further investigations are needed.

Summing up: the growth model of the Budapest agglomeration has been constructed to meet the demands outlined in this lecture. An attempt has been made here to draw up the growth problems of the agglomeration in a logical verbal model that would aid the solution of development problems of the agglomeration in the context of the development of the socio-economic potential of the country. We have presented a model that outlines at the same time the possible trends of further development of the socio-economic struc- 
ture of the agglomeration that should most effectively contribute to the spatial-economic development of the country. Appropriately used the model may reduce the imbalances emerging within the agglomeration of Budapest as well as in the intensive and selective development of the socio-economic potential of the agglomeration. The model assumes that the future period will have a fundamentally transitional character. 


\title{
THE PROCESS OF SUBURBAN DEVELOPMENT IN BUDAPEST
}

\author{
By \\ GYÖRGY ENYEDI
}

\section{DEVELOPMENT OF SUBURBS IN HUNGARY}

Suburbanization, outside Budapest, is a relatively new phenomenon in Hungary. In most cases industrialization provided the impetus for its development. The location of industry in Hungary was characterized for a long time by extreme concentration. In the 1930's factories located in the capital employed 60 per cent of the country's industrial workers. Before the Second World War the majority of Hungarian towns, especially those on the Great Hungarian Plain, had been unaffected by industrialization and consequently reached only a low level of capitalist development. They were mostly rural market towns with 20 to 30 per cent of their inhabitants engaged in agriculture.

The first stage of industrial expansion after the war (in the 1950's) affected only a few towns. Industrial activity was still centered in Budapest, resource extraction and heavy industrial centers located in the Central Hungarian Highlands underwent rapid development. Decentralization of industry continued at a greater pace in the second half of the 1960's and Debrecen, Szeged and Kecskemét, large towns situated on the Great Hungarian Plain emerged as important industrial centers. The newly located industries found adequate labour supply within these towns, and it is only in the past years that they have attracted labour from outside their administrative boundaries. In these towns we are witnessing the first signs of the birth of new suburbs. Only a few older industrial cities such as Budapest, Miskolc and Győr have a welldeveloped suburban belt surrounding them. However, if we wish to follow all the important stages and traits of suburban development in Hungary our choice must be limited to Budapest alone.

\section{STAGES OF SUBURBAN DEVELOPMENT IN BUDAPEST}

a) First stage (18\%0-1900): rapid industrial development in Budapest began after the Austro-Hungarian Compromise in 1867. Situated at a vital transport node in the Carpathian basin, the Hungarian Capital was at that time the second most important town of the Austro-Hungarian Monarchy. As an administrative and financial center, it attracted new industrial establishments. The first factories were mostly built near the river Danube, on the outer periphery of the residential area. Industrial growth, a significant expansion of the tertiary sector, and a booming building industry were signs of a rapid urban development. Jobs attracted large number of migrants from the overpopulated rural areas. The great demand for housing and for industrial 
sites provided favourable conditions for land speculation. The price of land compelled industrial plants with substantial space requirements to move to areas outside the city's administrative boundaries. Several thousand hectares were subdivided into plots from the large estates, formerly extensively cultivated, and which were found on the west bank of the river near to the capital. New residential districts with family houses were established on these small plots. Workers who were employed by those factories that were located outside the city boundary, lived here.

During the first stage of suburban development a new belt of industrial settlements emerged, especially to the north and east of the capital. Today it is found within the city's administrative boundary; it is the so-called inner suburban belt.

b) Second stage (1900-1920): during this stage the industrial suburban belt underwent spectacular development. In 1910, 41 thousand industrial workers from a total of 100 thousand employed in the capital worked in the factories situated in this belt. Commuters appeared on the scene: 15 thousand people commuted to other factories in Budapest. Suburban development engulfed more distant agricultural settlements around the city. Commuting began from these villages to the industrial plants of the inner suburban belt as soon as mass transportation became available.

The new suburban belt (called the outer suburban belt today) with a formally distinct rural outlook, had been transformed significantly. Agriculture remained an important activity, and milk, vegetables and fruit were sent to the city markets for sale. Peasant families had a mixed occupation with one or two members commuting to the city. A large number of migrants from distant parts of the country settled here. These people still had to travel to Budapest every day but accommodation was cheaper in these villages, and they had the chance to pursue some agricultural activities as well. No industry was located in this belt.

c) Third stage (1920-1945): the above outlined spatial rearrangement of people and industrial activity continued between the two world wars. Several industrial towns sprung up in the inner suburban belt. In 1938, 60 thousand people were working here (126 thousand in Budapest). Some industries established in the 19th century were driven out from Budapest partly by the expansion of residential districts, and partly because of the nature of their activity (e. g. food processing).

Suburban development intensified on the right bank of the Danube, on the Buda side. Modern industrial plants were built on the southern border of the city. These new suburbs were no longer simply communities set up by industrial workers, middle class people in the lower income bracket (mostly clerks) also settled here.

Specialization in market-gardening was so complete as to serve the needs of the city. The intensively cultivated farms employed many labourers. They ensured a better income than industry did, thanks to favourable marketing opportunities.

Between the two world wars summer houses cropped up in the suburban areas on the right bank of the Danube and tourist trade became a profitable enterprise. 
d) Fourth stage (after 1945): After the Second World War both the area and the population of the suburban belt grew. As a result of a decentralization policy, the relative importance of industry became less, though the number of people who were employed in industry still continued to increase, and the city's labour attraction was felt for a long time afterwards. Maximum industrial employment in Budapest was reached in 1964 (with 730 thousand people employed). There were two stages of rapid growth: the first between 1949-1954 and the second between 1957-1960. Between 1964 and 1974 the number of industrial workers dropped by 100 thousand! Gross industrial output meanwhile increased by 30 per cent. Total industrial employment in Budapest started to decrease only after 1969 (the maximum in 1969 was 643 thousand). Headquarters of nearly all large industrial enterprises are found in Budapest, the administrative, commercial and research staff included. This is the reason behind the significant differences between the number of workers and the total number of industrial employees in Budapest industry. Simultaneously with the decrease of the number of industrial workers, the total number employed by the service industry has increased continuously.

A dynamic population growth in Budapest during the last 25 years includes an additional half million immigrants and about 100 thousand people who settled in the suburban belt.

The most important changes that had occurred in the period after 1945 were the following:

I. The inner suburban belt was administratively united with the capital. In 1950, as part of a countrywide administrative reform, the inner suburban belt built at the end of the 19th century was annexed to Budapest. These suburbs included 7 towns and 16 villages which are contiguous with the capital and function as industrial or residential suburbs; 527 thousand people were affected. A certain degree of functional and morphological independence was preserved by these settlements, after they had merged administratively with the capital. Most of the new housing estates were built in the inner suburban belt, the inhabitants of which number almost 800 thousand today.

II. The spatio-economic contacts of the outer suburban belt had changed fundamentally. It became a multi-functional zone as the industries established here have close administrative ties and production links with industries elsewhere in Budapest. A settlement hierarchy has developed within this zone and independent satellite towns with their own area of attraction have emerged. Earlier the interrelationship between the city and these suburbs was fairly simple: Budapest employed the labour available from the suburbs and consumed the agricultural products of a particular suburb. In return it provided higher service functions for the inhabitants of these zones. The former townvillage relationship gradually became a hierarchical organization of suburban centers and attraction areas. 


\section{A SHORT DESCRIPTION OF THE PRESENT-DAY SUBURBAN BELT}

a) Area and population of the suburbs. The geographer always faces difficulties when he attempts to delineate functional territorial units. Opinion differs as to the area of the Budapest agglomeration. The city's attraction extends over different areas, depending on the functions we select e.g. labour attraction or attraction for schooling. We are greatly in need of a complex geographical synthesis of all these factors. The only thing researchers unanimously agree about, is that the actual functional zone of attraction is definitely greater than the recognized belt. Delimitation of this belt was done by the Central Bureau of Statistics, based mainly on available demographic and occupational data; 44 suburban settlements, including two towns, belong to this belt. The suburban belt which incorporates these 44 settlements was declared an official territorial unit by a Government decision in 1971 and subsequently would be included in the planning of urban spaces and reckoned with in development policies for the capital. The simple term "suburban belt" denotes this officially recognized one.

Immigration is responsible for the intensive growth of population in these suburbs. Between 1949 and 1970 their population increased by 62 per cent, while during this time the total population in Budapest rose by 22 per cent and Hungary's population growth was a mere 12 per cent.

Lively economic activity characterizes the suburbs. Industrial employment is especially high (55 per cent of the active population work in industry). In 11 settlements this ratio is even higher, since nearly two-thirds of all wage earners living in these settlements are employed by industrial firms. The ratio of those engaged in agriculture for the whole belt is 10 per cent, although in 4 settlements it exceeds 40 per cent.

Two-thirds of the active population work away from home (three-quarters of industrial workers commute) and 84 per cent of all commuters work in Budapest.

Eleven per cent of all people living in suburbs stay there only temporarily. The families of those employed by the building industry usually live in the countryside (the Great Hungarian Plain). They return to their permanent residence once a week or once in every two weeks.

The administrative restriction of migration to Budapest was the reason behind the great influx of migrants to the suburban belt. Apartments in state housing units or licences for building private houses are only granted if the person has been working or living in Budapest for at least five years. People who wish to settle in the capital are forced to wait in the suburbs before they can move in. The out-migration of people from the city to the suburbs which characterizes Western European and North American cities is a negligible factor in the population growth of the suburban belt around Budapest.

b) Industrial activity has greatly expanded in the suburban belt and industrial plants located in the suburbs employ 50 thousand workers. There were three motivating factors that aided development. 
- Large-scale industrial investment in the area, financed by a Government Budget (e.g. the Csepel Automobile Factory, the Petro-Chemical Plant at Százhalombatta). Some of these large plants will probably continue to expand in the future, although no plans are made for further great industrial investments in the suburban belt.

- Several factories were moved out from Budapest. In 1959 all industrial establishments located in the capital were classified, the criteria being whether there were any possibilities open for their future development. Some factories were forced to move out because of environmental reasons or because their presence impeded city planning. The removal of these establishments was subsidized by the government. At the time the decree was passed, the factories that were affected employed a total of 70 thousand people. The moving out of the factories has proved to be a prolonged operation, and many of them simply settle in the suburban belt.

- Industrial relocation by state companies. Since the economic reform of 1968 enterprises are entitled to invest their own technical development funds and state enterprises in the capital often establish subsidiary plants in the country, if the development of the mother company is restricted. Industrial activities which still have close ties with other industries in Budapest were moved to the suburban belt.

The relocated industrial sites in the suburban belt form industrial clusters and are not scattered all over. The building of new industrial establishments is prohibited both in the capital and in the surrounding suburban belt (with the exception of servicing enterprises). However, new capacities are often created by modernization at existing older industrial premises.

c) The importance of agriculture has greatly declined. Market gardening in this belt provides only 15 per cent of Budapest's vegetable requirements (in the 1930's the ratio was 60 per cent). Dairy farming has practically disappeared. As transport facilities have improved, the agricultural belt has moved further away from the capital as farmers look for the optimal site for growing their produce.

The cultivation of plots as a whole has become more extensive, and some intensive branches have developed spectacularly (e. g. the growing of mushrooms and flowers). Vegetable growing has declined because of lack of mechanization; 20 per cent of arable land is taken up by wheat growing, areas cultivated for fodder crop have also grown. There are more poultry and pig farms these days.

Agricultural activity in the suburban belt is, for all practical purposes, completely collectivized. Collective farms are managed profitably, the standard of cultivation is good, relatively small areas are farmed, but with solid capital backing. Their income is supplemented by food processing and retail trade. Industrial activity unrelated to agricultural production is not a rare phenomenon.

The growing of foodstuffs by the non-agricultural population is also noteworthy. In the suburban belt family houses are surrounded by large gardens and these are carefully cultivated. These households often keep poultry, rabbits and even pigs. The gardens cater for the family's need for provisions, and often produce for the market as well; 30 per cent of all fruit and eggs sold at Budapest markets come from the small gardens of industrial workers. 
d) Budapest's prominence as a tourist resort continues to be dominating. The city's geographical setting along the Danube river and near the forested hills of the Buda Mountains attracts vacationers. It is not only a week-end resort for the people of the capital, it is the second most favoured holiday spot in Hungary (the first is Lake Balaton).

The number of summer houses has increased in the past decade as the standard of living has begun to climb. They were built mostly along the Danube, but some stand on the shores of small lakes, former gravel pits, now filled with water. Local councils and collective farms were quite willing to subdivide uncultivated land into small plots for holiday homes. It proved to be an excellent source of income. Some holiday resorts are overcrowded, yet there are only a few government and company rest-houses.

e) The internal structure of the suburban belt is the following:

- Four satellite towns have developed in the belt or on its periphery. These are: Gödöllő, Százhalombatta, Szentendre and Vác. Gödöllő and Vác are not officially considered to be part of the suburban belt, although they are functionally interlinked. Százhalombatta is a new town: it is the housing estate for the Petro-Chemical Plant mentioned earlier. The other three towns are older settlements. Vác has a long historical past (Vác is a 900-year-old town). The towns acquired urban functions only in the past 30 years, important industrial establishments were located in the area, a University has moved out from Budapest to Gödöllő and a College to Szentendre. These small towns (Vác being the biggest with 33 thousand inhabitants) attract labour, services and cultural functions. The area of attraction partly coincides with the attraction belt of Budapest.

- Most settlements are multifunctional. Thirty to sixty per cent of wage earners stay in the settlements to work in industry, agriculture or in services, the rest commute. The settlements may be classified into the following types on the basis of the employment structure of the population and the ratio between those who stay and those who commute:

a. agricultural settlements (they show a random geographical distribution and are found on the periphery of the agglomeration. Transport and communication links to the capital are inadequate);

b. industrial settlements (a few villages with industrial establishments);

c. mixed working and residential settlements (these constitute the majority of cases);

d. lower order centers with a few service functions for the nearby villages. The development of the latter is planned so that they should serve as settlement hierarchical units between Budapest and the satellite towns.

The villages are large, half of the suburban residents live in settlements with more than 10 thousand inhabitants, yet the services they offer are few and inadequate. They rely on Budapest to satisfy such demands. However, some functions e. g. education, health and trade should be decentralized, and Budapest freed from the burden of serving these villages as well. A few examples: 67 per cent of secondary school children and 77 per cent of students of vocational schools study in Budapest; 86 per cent of commuters buy articles of clothing in the capital and 73 per cent buy food as well. Their basic needs are not catered for at their places of residence. 
f) Social stratification in the suburban belt. The functional classification of settlements has already indicated that their employment structure differs. It is legitimate to ask whether we experience some sort of social segregation in the sense that people of a given social strata would be banned from a settlement, but this does not exist. The high ratio of workers is usually justified by the location of industrial establishments in the area. However, in a few settlements a concentration of people with intellectual occupations is noticeable. Strictly speaking we refer to these settlements on the right bank of the Danube that are situated in an attractive physical setting, and which had begun to turn into non-industrial suburban holiday resorts in the 1930's. The survival of this tradition can be explained by the following:

a. Many white collar families have simply moved out from the capital to their former second homes.

b. The average income of these families is 30 per cent more than that of workers, and they can pay for the higher land prices of the right bank.

c. White collar families look for an attractive physical environment in the first place and are content to have only a modest garden. Worker families, many of whom come from villages, want to have a large garden where they can practice auxiliary farming. This is the reason why they have settled on the left bank of the river on the Pest-Plain where land prices are lower.

d. Many of the intellectuals who live in settlements with poor transport links have no fixed working hours (e. g. research workers, artists etc).

This does not mean, however, that separate suburban towns have been created where only white collar people live. This is proved by a comparison of the employment structure of two settlements, both extreme cases: Leányfalu is a settlement of white collar families while Szigethalom is inhabited mostly by workers.

\begin{tabular}{|c|c|c|c|c|c|c|c|c|}
\hline \multicolumn{9}{|c|}{ Percentage distribution of wage earners (1970) } \\
\hline & $\underset{\text { try }}{\text { indus- }}$ & $\begin{array}{l}\text { build- } \\
\text { ing } \\
\text { indus- } \\
\text { try }\end{array}$ & $\begin{array}{c}\text { agri- } \\
\text { culture }\end{array}$ & $\begin{array}{c}\text { com- } \\
\text { merce }\end{array}$ & $\begin{array}{l}\text { trans- } \\
\text { port }\end{array}$ & $\begin{array}{l}\text { ser- } \\
\text { vices }\end{array}$ & $\begin{array}{l}\text { health+ } \\
\text { educa- } \\
\text { tion }\end{array}$ & $\begin{array}{l}\text { admin- } \\
\text { istra- } \\
\text { tion+ } \\
\text { the rest }\end{array}$ \\
\hline \multirow{2}{*}{$\begin{array}{l}\text { Leányfalu } \\
\text { Szigethalom } \\
\text { Average for the } \\
\text { suburban belt }\end{array}$} & $\begin{array}{l}35 \cdot 1 \\
72 \cdot 2\end{array}$ & $\begin{array}{l}4 \cdot 7 \\
3 \cdot 9\end{array}$ & $\begin{array}{l}8 \cdot 8 \\
5 \cdot 6\end{array}$ & $\begin{array}{r}10 \cdot 5 \\
6.7\end{array}$ & $\begin{array}{l}8 \cdot 8 \\
5 \cdot 4\end{array}$ & $\begin{array}{l}2 \cdot 4 \\
1 \cdot 2\end{array}$ & $\begin{array}{r}20 \cdot 9 \\
3 \cdot 1\end{array}$ & $\begin{array}{l}8 \cdot 8 \\
1.9\end{array}$ \\
\hline & $54 \cdot 4$ & $7 \cdot 8$ & $10 \cdot 8$ & $8 \cdot 1$ & $7 \cdot 5$ & $1 \cdot 7$ & $5 \cdot 8$ & $3 \cdot 9$ \\
\hline
\end{tabular}

\section{PROBLEMS OF DEVELOPMENT}

a) If we wish to develop the suburban belt, the biggest problem we have to face is how to level off the enormous differences in living conditions and infrastructural services in the various settlements. Infrastructural investment has lagged behind population growth and the suburban belt has become overcrowded. 
For a long time development plans for the capital and the suburbs were not coordinated. Although in the last few years simultaneous plans of development were drawn up for the whole agglomeration. Not very long ago local councils were granted more independence, public revenue may now be locally invested. Still, public revenue in the villages lying within the suburban belt is negligible compared to their population size. People employed by state companies and cooperatives, this means the majority, do not pay income tax. It is directly paid by the firm which employs them to the council of the district where the establishment is located. Consequently, tax paid for the commuters is sent to Budapest Council.

b) From among the problems connected with living conditions, the most urgent is the question of housing. Housing conditions in the suburban belt are worse than the national average. Undoubtedly housing conditions were even worse before 1945. Many poor workers settled in the suburban belt. Most houses had one room flats, with no water, drainage or electricity; 56 per cent of all the houses in Budapest today were built before 1945 and 14 per cent before 1900. (The average age of houses in the whole country is even greater.) Many outdated houses were built in the 1950's. After 1960 housing enjoyed a boom period. Thirty thousand flats were built between 1960 and 1970, total housing stock increased by 39 per cent. Housing constructions could just keep pace with the rate of population growth in the area, however, this could not solve the inherited housing shortage. Fifty per cent of flats today still have only one room; 3.42 tenants live in one flat $(3.04$ in Budapest). The flats are poorly equipped: only 25 per cent have running water and connection to the sewage system and only 30 per cent have bathrooms. Gas supply is relatively good: 56 per cent.

Average housing conditions show a great disparity. Government financed housing constructions were mostly built at selected sites, and concentrated on a few settlements. Thus in four settlements more than half of the housing stock is not older than ten years (1960-1970), while at five others, one third of the houses were built in the last century. In fifteen settlements less than 10 per cent of all the houses are connected to the sewage system, $5 \cdot 8$ per cent of the population do not possess a flat, they are subtenants, and in four settlements this ratio is even higher and exceeds 10 per cent. Differences stem from the chances and means local councils are provided with for development.

c) Another important requirement for future development is the improvement of transport facilities. The actual distances covered are not so great, yet the time spent is far too long and travelling is uncomfortable. Long term plans have been worked out for the extension of mass-transporting facilities to meet existing demands. Railway lines cater for two-thirds of all commuters today, but only 10 per cent can take a suburban train to the capital.

Sociologists insist that commuters should move in and settle in Budapest because of the disadvantages of daily travelling. This proposal lacks insight in the sense that suburbs provide a more pleasant environment than those monotonous estate houses built of concrete blocks. To settle 200 thousand commuters in Budapest would require heavy infastructural investment, where- 
as less would be needed for the improvement of transport facilities, and infrastructure in the suburbs.

Industrial workers and tertiary employees living in the suburbs are entitled to enjoy the same living standard as those who stay in Budapest. Their expectations cannot be fulfilled within a short term, since this would require much effort by many. However, if we wish to level off differences in living conditions, this effort must really be made urgently.

\section{REFERENCES}

A budapesti agglomeráció településeinek jellemzöi (Characteristics of Settlements of the Budapest Agglomeration). Központi Statisztikai Hivatal, Budapest, 1974.

Budapest társadalmának és gazdaságának százéve (People and the Economy of Budapest in the Last Hundred Years). Edited by T. Bernát and M. Viszkei, Közgazdasági és Jogi Kiadó, Budapest, 1972.

Bencze, I.-Tajti, E. (1972): Budapest, an Industrial-Geographical Approach. Akadémiai Kiadó, Budapest.

Enyedi, Gy. (1976): Hungary. An Economic Geography. Westview Press, Boulder (USA).

Fodor, L. (1973): Falıak a nagy áros árnyékában (Villages under the Influence of the City). Kossuth Könyvkiadó, Budapest.

Mrs. Pesti, L. (1974): Az agglomeráció-vizsgálat módszerei, a lehatárolás és a folyamatos statisztikai megfigyelés megszervezésének egyes kérdései a budapesti agglomerációban (Methods Related to the Study of an Agglomeration, Problems Connected with the Demarcation and Continuous Statistical Observation in the Budapest Agglomeration). Területi Statisztika, 24, pp. 1-19. 
, 


\section{THE RELATIONSHIP BETWEEN THE CITY OF DEBRECEN AND SURROUNDING SETTLEMENTS}

By

ANTAL PAPP

\section{A RAPIDLY DEVELOPING CITY IN A HETEROGENEOUS ENVIRONMENT}

The city of Debrecen is, both from the point of view of its population and of its function in the network of surrounding settlements, one of the most prominent members of the city network in the country. In 1974, its population was 176,665 . Thus it is the most populated city of the Hungarian lowlands and, after Budapest and Miskolc, it is the third largest city in the country. In the settlement hierarchy, it is one of the five leading cities in Hungary. Through its organizational, official, cultural and health institutions it is the highest order center of the north-eastern part of the country.

The development of significant connections between this city and its surroundings started only about a decade ago. One of the factors which hindered the development of these connections consisted of an abundance of manposver in Debrecen, the background of which was protracted and moderate economic development. Characteristic of the underdevelopment of economic activity and for the existence of surplus manpower is the fact that in 1949, 39.3 per cent of the population (26,963 people) had no income of their own. At this time only 2.4 per cent of the actively employed (that is 12,476 persons) were working in industry or in construction. Industry was represented by a few plants, mainly belonging to the agricultural industry. The highest number of the employed were working in the tertiary sector. Some 32.4 per cent of the actively employed were in administration, in cultural, health and other public services, whereas the number of those employed in transportation, telecommunication and commerce amounted to 17.9 per cent. The number of those working in the tertiary sector $(50.3$ per cent) was higher than those working in the producing sector (49.7 per cent).

As a consequence of the underdevelopment of industrial activities, there was a large surplus in manpower and a further potential reserve was repre sented by the manpower freed from agricultural work, as well as by the significant natural increase of the city population.

In addition to the availability of manpower, there were some other factors which supported, at the beginning of the 1950's, the development of the industry of Debrecen, namely the existence of an infrastructure which was, as compared to the other cities of the lowlands, rather a developed one, plus the possibility of cooperation with scientific institutions.

During the period 1949 to 1973, about 45,000 new working places were created at Debrecen, 30,000 of these in the industry and in construction. Some plants were created (that are of nationwide importance) such as the Hungarian Ball Bearing Works, the medical instrument plant "Medicor", the pharmaceutical company "Biogal", the plastics-processing firm "Hungaria", the 
clothes-producing, poultry processing and house-building factories as well as the plant for the production of educational instruments.

With the rapid increase in working places, and particularly in industrial working places, the local reserves of manpower had already been exhausted by the beginning of the 1950's and the inflow of manposer into the city had started. The attraction of manpower manifestated itself primarily in the

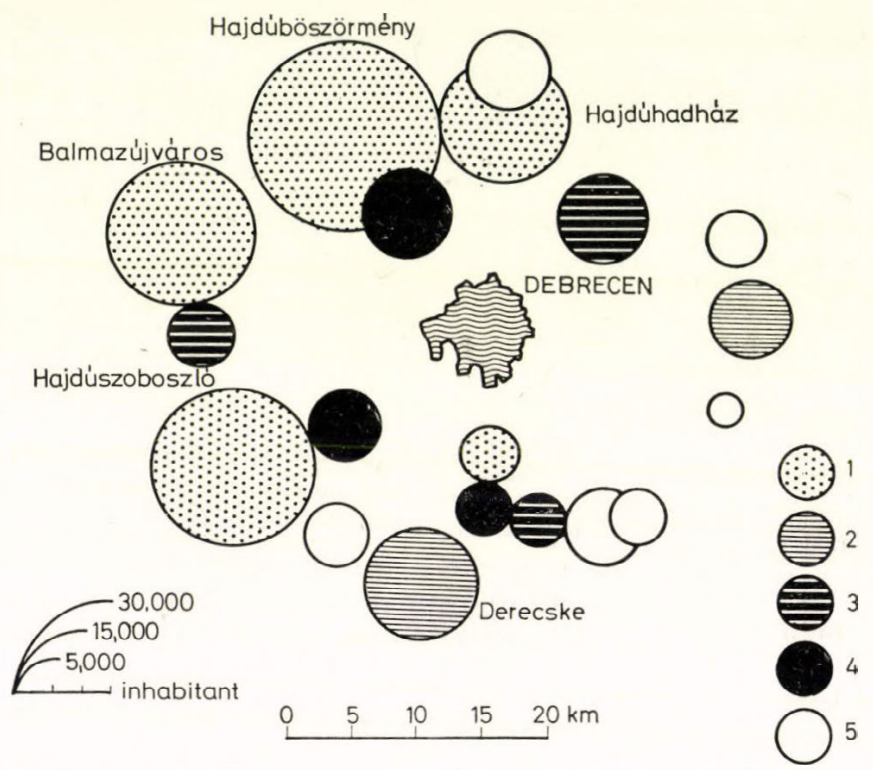

Fig. 1. Rate of immigration to the settlements surrounding Debrecen (1950-1974)

Number of immigrants out of 100 families

$1=<10 ; 2=10 \cdot 1-15 \cdot 0 ; 3=15 \cdot 1-20 \cdot 0 ; 4=>20 \cdot 1 ; 5=$ no data

form of immigration and commuters were at first only of minor importance. The immigration difference of the city amounted, for the period 1960-1973 to 28,200 persons. Immigration was rendered possible by enhanced construction of flats which exceeded the natural increase of the city population. Between 1960 and 1973, the population of Debrecen increased by 34.2 per cent, while the number of flats $(18,270)$ increased by 50.8 per cent (Fig. 1).

During the 1950's, as a consequence of the existence of a local surplus in manpower, and, during the 1960's, as a consequence of the enhanced building of flats, the working relation between the city of Debrecen and its surrounding settlements has developed with a lower intensity than in other Hungarian cities. The number of commuters reached the value of 10,000 persons only at the end of 1960's and they are yielding only some 10 to 12 per cent of all people employed in the city.

In spite of the rapid industrialization process, Debrecen is not an industrial city. In 1973 , only 46.4 per cent of the active population was employed in 
industry and construction. This is only slightly higher than the national average. In the employment structure of Debrecen, the tertiary sector still has a very high importance. It consists of 45 per cent of the active population, which indicates the great role of the supply functions of the city. The supply and servicing activities have two characteristics: small-scale commerce and its attraction is less significant as compared to other large cities, while the functions in culture, health and partly those of administration are rendering Debrecen the most important center in the northeastern part of this country.

Debrecen is surrounded by a heterogenous settlement, demographic and economic belt which means that the relations between the city and its surroundings differ from one settlement to another. Before the presentation of these relations, we shall review the more important peculiarities of the surroundings.

a) Within a radius of 25 kilometers from the center of Debrecen (from where the city may be reached in less than 40 minutes) there are 17 settlements. These are very different from the point of view of population which varies between 2,000 and 30,000 persons. From the point of view of the relations, it is important, that 5 settlements have a population above 9,000 persons and two of them (Hajdúböszörmény and Hajdúszoboszló) are cities from an administration standpoint. The total population of the 17 settlements amounts to 140,000 persons of which 66 per cent are living in settlements having more than 9,000 people.

b) The surroundings of the city are heterogeneous also with respect to demography. Agriculture is predominant in 35 per cent of the settlements. In these settlements, 40 to 70 per cent of the actively employed are working in agriculture. With the development of industry and other activities three of the settlements are becoming minor centers of demographic attraction. Téglás is a settlement of distinctly industrial character, where 67 per cent of the actively employed are working in industry. Hajdúszoboszló is an important health resort and spa and, at the same time, it is a minor industrial center where one-third of the employed are working in industry, and one-third in the tertiary sector. Hajdúböszörmény in the 1960's was still an agricultural town belonging to the attraction sphere of Debrecen, but its industrialization has proceeded very rapidly. In this settlement, there are today 4,500 industrial workplaces. These settlements are today insignificant from the point of view of the manpower supply of Debrecen.

The industrial development of some settlements in the surroundings of the city has meant that the formerly low-level economic activity of the population has been improved. From the population of working age, in 1970 there was a manpower surplus of 15,900 people. Recently, some 10,000 workplaces have been created at Debrecen and its surroundings and the manpower surplus has significantly decreased. In the second half of the 1970's, the number of people entering working age in the 17 settlements will exceed only by 1900 the number of those of retiring age, while in Debrecen, this number will equal to 1,100. Further it is probable, that the manpower released from agriculture will be equally low, as in the East and the South of Debrecen (in the area called Hajdúság) agricultural units are already strongly mechanized employing very few people and at present these are the areas which have been primarily 
industrialized. It is expected that, in the future, mainly in the East of Debrecen, in the agricultural areas of Nyírség, manpower will be released from agriculture. In this area, 40 to 50 per cent of the actively employed are still working in agriculture. There is a high density of agricultural population and the income, available from agriculture, is rather low. In the settlements of Nyírség, agricultural income is 40-50 per cent lower than in Hajdúság. The low income level is obviously facilitating a change in activities. It is probable that in the working relations between Debrecen and its surroundings, the role of the eastern regions, that is the settlements in Nyírség, will be further enhanced.

The employment conditions in the surroundings of Debrecen have been improved, is also supported by the number of population in the settlements. During the 1960's (with the exception of settlements in the vicinity of Debrecen: Józsa, Ebes, Hajdúhadház as well as with the exception of Hajdúszoboszló and Téglás) the number of population decreased, as a consequence of emigration, by 2-10 per cent in ten years. Since the end of the 1960's, the population in 8 settlements has increased and in 3 settlements it is stagnating. There are 6 settlements where population is still decreasing. Two of them (Hajdúszovát and Nagyhegyes) have no good transportation facilities toward Debrecen. The settlements increasing at the highest rate are Józsa, Ebes and Sáránd. Into these settlements, people from more remote regions are immigrating to work at Debrecen, and sporadically an emigration from Debrecen into these settlements is occurring.

c) The network of institutions in Debrecen and its surroundings is well developed, particularly the netsork of small-scale commerce. Industrial shops are lacking in only 5 settlements with the smallest population. In the most populated settlements, however (Hajdúböszörmény, Hajdúszoboszló, Balmazújváros, Derecske), there are shops and warehouses for the satisfaction of the less frequently required commodities (furniture, clothing). The relatively better availability of shops selling industrial articles and specialized shops in the larger settlements is primarily the consequence of the larger demand, it is connected also with the underdevelopment of the relations between city and villages. In the presence of this kind of distribution of small-scale commerce, the attraction of Debrecen in the field of small-scale commerce is only significant for some of the surrounding settlements.

\section{CHARACTERIZATION AND EVALUATION OF THE RELATIONS}

The data necessary for this investigation have been collected by circulating questionnaires and by local interviewing of the population. Data collection was extended to 13 settlements, in which 10 to 30 per cent of the families (in total 5,845 families) were asked to answer the questions. Data collection has been carried out with highest intensity in the less populated settlements attracted to Debrecen. From the material obtained in this way, we endeavoured to obtain an answer to the following questions: 
a) Which is the rate of immigration and how is it connected with employment in Debrecen? Do the immigrants intend to settle down or do they intend to immigrate to Debrecen?

b) How strong an attraction is exerted on manpower in the field of smallscale commerce, health, cultural institutions and repair services of the city of Debrecen, and which factors determine it?

c) How strong are the relations in the fields of small commerce, cultural activities, health and repair services for each settlement, and on what factors does it depend?

Immigration is of significance only in the case of settlements which are located in the immediate vicinity of Debrecen. Every fourth or fifth family inverviewed in villages Ebes, Józsa, Sáránd and Hajdúbagos, had settled there in the last 25 years. In spite of the rather important immigration, the increase in population was rapid only in the two villages Józsa and Ebes (exceeding 15 per cent). The population of Sáránd remained almost unchanged, and that of Hajdúbagos decreased. In these two settlements, emigration exceeded immigration and the exchange of population was a very high one. It can be assumed that the majority of the emigrants had immigrated to Debrecen. The two settlements, exhibiting the highest rate of immigration and, at the same time, the highest degree in population increase are located in the immediate vicinity of Debrecen which may be reached in 13 and 18 minutes respectively. It is conspicuous that, at the same time, to Mikepéres, which has equally good communications with Debrecen, almost no immigration has taken place and from here population is emigrating. Immigration into the surrounding villages is motivated by a number of factors, such as the environment of the settlements, its infrastructure, etc.

A direct and positive connection between immigration and employment in Debrecen has been found only in the villages Józsa, Sáránd and Ebes. The two phenomena are positively correlated, having the low value of $r=0 \cdot 3035$.

The immigration into the villages occurs mostly with the intention of the final settling down, and only a small fraction of the immigrants have the goal of a further migration to Debrecen. This is reflected by a correlation coefficient between immigrations and transmigrations to Debrecen, of $r=0 \cdot 7286$.

There are 6 settlements over which Debrecen is exerting a significant manpower attraction. From these, in the village of Józsa, 74.4 per cent and in the village of Mikepércs, 60 per cent of the actively employed are working in Debrecen. These two settlements are already the dormitory tospns of Debrecen. From Sáránd and Hajdúsámson, 53-55 per cent of the working population, from Vámospércs, 47 per cent, and from Ebes 33 per cent are working in Debrecen. From all these villages, Debrecen may be reached by railway or road in less than 30 minutes (Fig. 2).

Between the transport facilities to Debrecen and taking a job in Debrecen there is no positive correlation, even when the cities of Hajdúböszörmény and Hajdúszoboszló are disregarded. Even in these cases, the correlation coefficient has a value of only $r=0.6877$ that is, the closeness of the relation is rather a moderate one. The manpower attracting effect of minor industriae centers in the vicinity of Debrecen, as well as the various availability of frel 


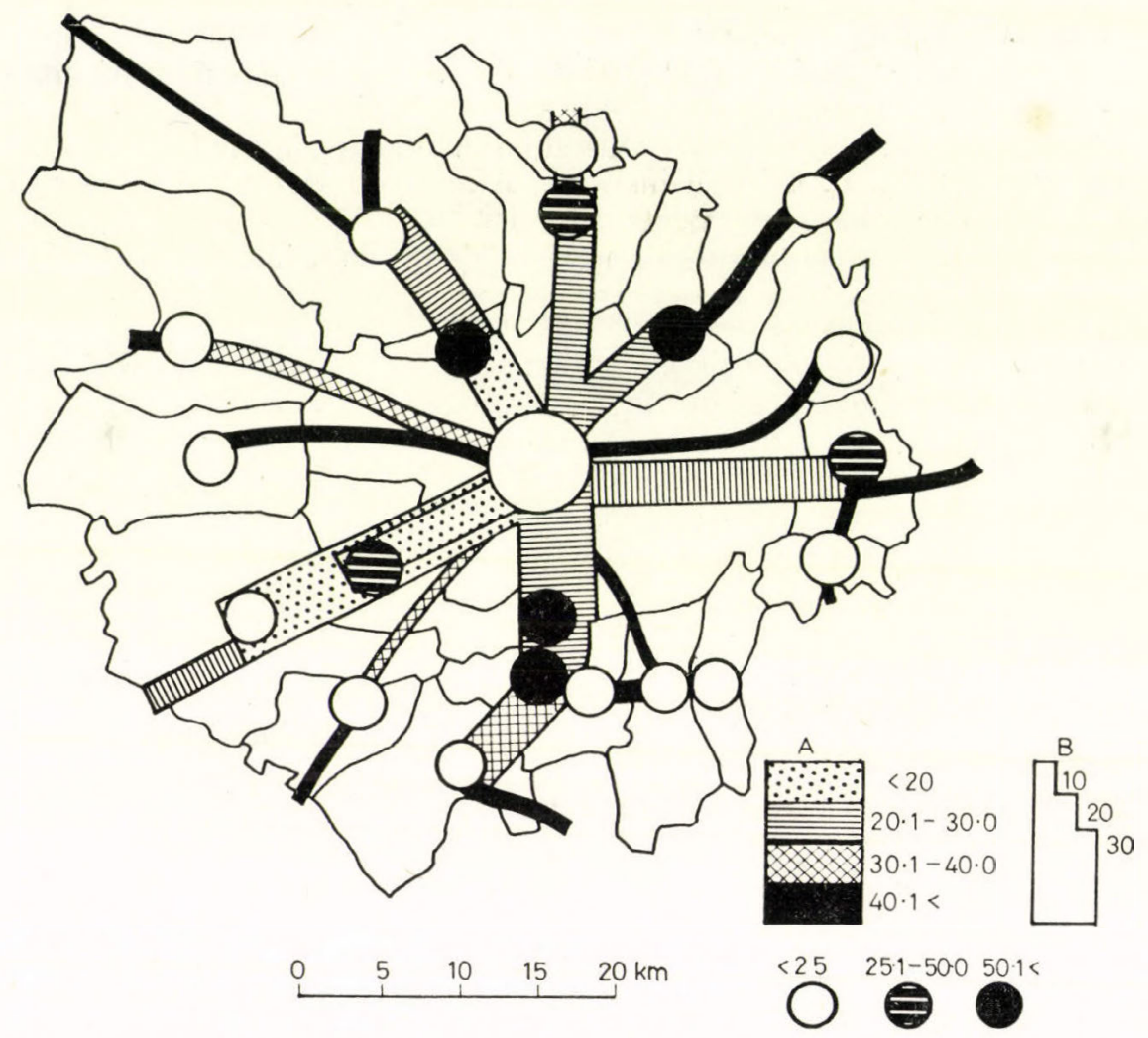

Fig. 2. Possibility of daily commuting to Debrecen by train and bus; rate of daily commuters compared to active earners; time needed for commuting to Debrecen

$\mathrm{A}=$ time of commuting ( $\mathrm{min}$.) $\mathrm{B}=$ possibility of daily commuting; $\mathrm{C}=$ number of commuters compared to 100 active earners

manpower in the different settlements, and finally the high differences in the agricultural income also influence the relation between attraction of manpower and transport facilities.

Agricultural income (i.e., the annual per capita income from the activities of agricultural cooperative units) correlates with the taking of jobs in Debrecen, yielding a value of $r=0.5208$. Among the settlements having the highest agricultural income, only the village Ebes is experiencing a stronger manpower attraction from Debrecen. In the settlements of Hajdúság, the income available from agriculture is higher than the possible industrial income for non-trained manpower.

The attraction in the field of small-scale commerce, which most comprehensively characterizes the relations between city and village, is (as a consequence of the circumstances already mentioned above) a moderate one. The availability of shopping facilities is generally worst in the settlements 


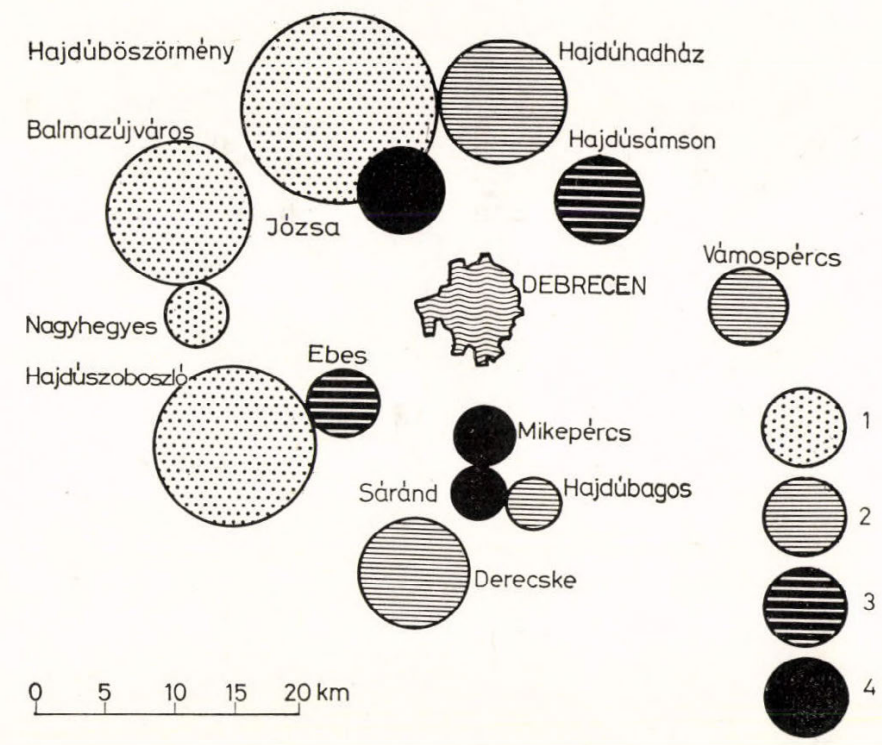

Fig. 3. Annual number of "connections" with retail and other urban services, per family

Number of "connections" (1 family/year); $1=<50 ; 2=50 \cdot 1-100 \cdot 0 ; 3=100 \cdot 1-150 \cdot 0 ; 4=>150 \cdot 1$

in which the manpower attraction of Debrecen is the strongest. From these at Mikepércs, 76 per cent of the families interviewed, and at Józsa, 60 per cent of them buy their requirements for industrial articles at Debrecen (Fig. 3). In the other settlements, which are subjected to the manpower attraction of Debrecen (Sáránd, Hajdúsámson, Vámospércs, Ebes) 30 to 45 per cent of the families shop in Debrecen. The attraction of Debrecen in the field of smallscale commerce depends on the availability of shopping facilities (correlation coefficient: $r=0.9119$ ) and on the rate of job taking in Debrecen (correlation coefficient: $r=0.8347$ ). The correlation coefficient for the relation to transport facilities is $r=0.4083$.

The cultural and recreational facilities of Debrecen offer the possibility for varied cultural relations of rather high intensity. With the exception of Hajdúszoboszló and of the village Nagyhegyes which belongs to the attraction sphere of Hajdúszoboszló, 15-30 per cent of the families used the cultural and recreation facilities of Debrecen during 1974. There are different degrees of intensity of these relations. In the majority of the settlements which belong to the attraction sphere of the city, 7-10 cultural visits occurred in each family. Cultural relations (with the exception of the case of small-scale commerce) exceed all other kinds of relations. (Relations in the field of public health amounted to 1 to 3 per family, relations with repair services varied between 0.5 to 2 per family).

The intensity of cultural relations is again related to taking of jobs in Debrecen. Correlation coefficient between these factors has a value of 
$r=0.8516$ while that between this intensity and the transport facilities to Debrecen has a value of $r=0.4872$.

With the exception of job taking, the per family values of all the other relations were highest at Mikepércs $(199 \cdot 6)$ and then at Józsa, at Sáránd, at Ebes, and at Hajdúsámson (values between 160.5 and $127 \cdot 3$ ). These five settlements also have the closest connection to Debrecen as regards manpower attraction. Globally the relation is in closest connection with the taking of jobs in Debrecen. The correlation factor expressing the degree of closeness is equal to $r=0 \cdot 8299$.

There is a moderate relation, however, in a negative sense, between global relations and the population of the surrounding settlements, the correlation factor having the value of $r=0.6332$ while correlation with transport facilities to Debrecen is equal to $r=0 \cdot 3893$.

\section{INTERPRETATION AND CONCLUSIONS}

1) The relation between the city of Debrecen and the settlements of its surroundings is still rather underdeveloped, although among the settlements located in the immediate vicinity of the city there are already actual dormitory towns. Further three settlements (Sáránd, Hajdúsámson and Ebes) are also exhibiting agglomeration trends.

2) Relations are varied and have various degrees of intensity, because their development is taking place under heterogeneous conditions.

3) At present stage of development, the role of transportation facilities is not strong. The most important relation is that of jobs, because this is the source of most of the other relations and the strength of these depends on this factor. Accordingly, the complex attraction sphere is better expressed by the manpower attraction sphere than by the attraction sphere of small-scale commerce.

4) Debrecen has a "half-sided" attraction sphere extending still more and more toward the East, that is, Debrecen is exhibiting an eccentric position within its attraction sphere. It is expected that in the future, the position of the city will become still more peripheral. The industrialization which has taken place in the recent years, has partly removed Hajdúböszörmény, Téglás, Hajdúszoboszló (and, together with them, also Hajdúhadház) from the attraction sphere of Debrecen. 


\section{AN INDEX OF CITY STRUCTURE BASED ON EMPIRICAL OBSERVATIONS}

By

DONALD R. DESKINS, JR.

\section{INTRODUCTION}

The city's changing residential patterns have long been a topic of concern for geographers, sociologists and other social scientists. Much of this concern has been centered on the evaluation and criticism of the hypotheses of city growth and structure generated by sociologists at the University of Chicago nearly a half century ago. ${ }^{1}$ BURGESS' hypothesis on city growth and structure is widely recognized as the first formal statement through which changing intra-city residential patterns can be viewed. Not only does this hypothesis provide a construct detailing the intra-city arrangement of residential areas of varying quality, but it also suggests that the dynamic nature of the pattern can be better understood and interpreted as the results of the ecological processes of: (1) centralization; (2) decentralization; (3) segregation (voluntary and involuntary); and (4) invasion and succession. ${ }^{2}$

1 Hypotheses on city growth and structure: HarLan H. Barkows: Geography as Human Ecology. Annals of the Association of American Geographers, XII, March, 1923, p. 10; ERNest W. Burgess: The Growth of the City. In The City, Ed. by R. E. Park, E. W. Burgess and R. D. MeKenzie, Chicago: University of Chicago Press, 1925, pp. 47-62; Chauncr D. Harris and Edward L. Uluman: The Nature of Cities. Annals of the American Academy of Political and Social Science, CCXIII, Nov. 1945, p. 13; Homer Hoyt: The Structure and Growth of Residential Neighborhoods in American Cities. Washington, D. C.: U.S. Government Printing Office, 1939; Richard M. HuRd: Principles of City Land Values. New York: The Record and Guide, 1924, pp. 56-74; and Roвеrт E. PARK: The City: Suggestions for the Investigation of Human Behavior in the Urban Environment. American Journal of Sociology, XX, March, 1915, pp. 557-578.

Criticisms of the hypotheses on city growth and structure: Mrlua Alrhav: Social Ecology: A Critical Analysis. New York: Columbia University Press, 1938; Maurice R. Davie: The Pattern of Urban Growth. In Studies in the Science of Society, Ed. by George P. Murdock, New Haven: Yale University Press, 1937; Walter Firey: The Land Use in Central Boston. Cambridge, Massachusetts: Harvard University Press, 1947; James A. Quinn: The Burgess Zonal Hypothesis and Its Critics. American Sociological Revies, V, April, 1940, pp. 210-218; James A. Quinn: Human Ecology. New York: Prentice-Hall, 1950, pp. 125-137; and Lloyd RodwIn: The Theory of Residential Growth and Structure: Evaluation of Prevailing Theories. Appraisal Journal, XVIII, July, 1950, pp. 295-317.

2 Noes P. Gist and Syrvia F. Fava: Urban Society. New York: Thomas Y. Crowell, 1964, contains a general discussion on the interrelationships between the ecological processes and city growth. Specific detail on the centralization and decentralization processes appears in Charles C. Colby: Centrifugal and Centripetal Forces in Urban Geography. Annals of the American Association of Geographers, XXIII, March, 1933, p. 17. The process of segregation receives detailed treatment in Thomas J. Woffter, Jr.: Negro Problems in Cities. Garden City: Doubleday. Doran, 1928; and Kard E. Raeuber and Alma F. Taeuber: Negroes in Cities : Residential Segregation and Neighborhood Change. Chicago: Aldine, 1965. Invasion and succession as a process are fully discussed in OTIS D. DunCan and BeverLy Duncan: The Negro Population of Chicago: A Study of Residential Succession. Chicago: University of Chicago Press, 1957; and Amos H. Hawlex: Human Ecology: A Theory of Community Structure. New York: Ronald Press, 1950. 
It is well-documented that Burgess' hypothesis has been heavily criticized as being devoid of cultural values and applicable only to the twentieth century industrialized North American city. ${ }^{3}$ Nonetheless, the hypothesis has well withstood this criticism and continues to provide a useful framework for urban research. Not only has it survived, but it has also been modified and used as the basis for examining city structure in Latin America and more recently in New Zealand. ${ }^{4}$

In the case of Latin America, researchers had long recognized that the intra-city arrangement of residential areas differed from those observed in North American cities. In fact, the pattern of residential areas stratified by neighbor quality or social status found in Latin American cities is the inverse of that found in North America. ${ }^{5}$ Similarly, this generalization holds when viewing the intra-city residential pattern of the preindustrial city. ${ }^{6}$ Until Schnore's essay "On the Spatial Structure of Cities in the Two Americas" appeared, the residential structure of the Latin American city was only viewed as being different, and few researchers viewed these differences in residential pattern as stages in the evolutionary sequence or continuum of city growth and structure. ${ }^{7}$ After the notion of an evolutionary sequence in city structure had become legitimate, differences in city structure were described or determined solely by comparing land use maps for two or more years. Schnore supports this point in his discussion of the studies focusing on the structure of Latin American cities when he states that: "Although almost all of the reports (on Latin American cities) contain one or more maps, there is relatively little use made of statistical data other than census reports and estimates of city size."8 It is now recognized that the notion of viewing city structure in an evolutionary sequence is an acceptable framework, however, to date few studies have deviated from using land use maps for two or more periods to achieve this goal. The results of these efforts continue to be descriptive essays. It should also be noted that these studies do not cover long periods of time, and they usually determine the difference in city structure by viewing city structure at two points in time and generally do not cover a time period which exceeds a decade.

3 WALter Firey: Sentiment and Symbolism as Ecological Variables. American Sociological Review, X, 1945, pp. 140-148; W. Firey: The Land Use in Central Boston; W. Firey: Residential Sectors Re-examined. Appraisal Journal, XXVII, 1950, pp. 451-454; and James A. Quinn: The Burgess Zonal Hypothesis and Its Critics.

${ }^{4}$ Ronald J. Johnston: Toward a General Model of Intra-Urban Residential Patterns: Some Cross-Cultural Observations. In Progress in Geography: International Reviess of Current Research, IV, Ed. by Christopher Board, R. J. Chorley, P. Haggett and D. R. Stoddart, London: Edward Arnold, 1972; and Leo F. Schnore: On the Spatial Structure of Cities in the Two Americas. In The Study of Urbanization, Ed. by Ph. M. Hauser and L. F. Schnore, New York: John Wiley and Sons, 1965.

${ }^{5}$ Leo F. Schnore: On the Spatial Structure of Cities in the Two Americas. 358 p.

${ }^{6}$ Gideon Sjoberg: The Preindustrial City: Past and Present. New York: Free Press, 1960, pp. 91-105; and G. S ловеRG: Cities in Developing and Industrial Societies: A Cross-Cultural Analysis. In The Study of Urbanization, Ed. by Hauser and Schnore, pp. 213-263.

7 R. J. Johnston: Toward a General Model of Intra-urban Residential Patterns. In Progress in Geography pp. 86-91; and L. F. Schnore: On the Spatial Structure of Cities in the Two Americas, pp. 370-374.

${ }^{8}$ Leo F. Schnore: On the Spatial Structure of Cities in the Two Americas. 360 p. 


\section{OBJECTIVE}

It is the objective of this effort to examine city structure (the intra-city arrangement of neighborhoods) over a long period of time (a century or more) to develop an index that will label city structure and establish where a particular city structure fits on the preindustrial-industrial city structure continuum. This objective is pursued by examining the pattern of residential areas found in the city of Detroit, Michigan for selective years between 1837 and 1970. Before this examination is made, certain assumptions must be considered.

\section{ASSUMPTIONS}

Burgess' hypothesis on city structure employed land use categories as the basis to establish the intra-city residential area arrangement. Recently, researchers have relied heavily upon socio-economic data recorded in various censuses as the basis for establishing intra-city arrangement of residential areas. ${ }^{9}$ It is obvious that census tract data were generally not available for most U.S. cities prior to 1940, and that land use maps, if available, vary in quality and coverage. ${ }^{10}$ To realize the objective of this effort which is to establish indices describing city structure for selective years and to place a particular structure along a preindustrial-industrial continuum requires a data source that will all allow intra-city residential areas to be identified over a long period of time.

Data for the city of Detroit for this purpose are available for selected years covering a period of nearly 130 years. Before the data are discussed in detail, it is necessary to argue that income is the most important factor in determining an individual's ability to rent or purchase a residence, thus income is a strong factor in determining an individual's residential location. Recognizing that the role of income in determining residential location is not to be minimized, occupation level, which is highly indicative of income, appears to be the principal factor in determining an individual's class position as well as being very important in establishing his life style. Occupation largely determines an individual's associations and interests, therefore defining the group to which the individual is likely to belong. ${ }^{11}$ Interpreting these relationships spatially, it can be said that occupation strongly influences an individual's

${ }^{9}$ Brian J. L. Berry (guest editor: Comparative Factorial Ecology. Economic Geography, XLVII, No. 2, Supplement, June, 1971; Ronald J. Johnston: Zonal and Sectoral Patterns in Melbourne's Residential Structure, 1961. Chicago: University of Chicago, Department of Geography, Research Paper, 116, 1969; and PHILIP H. Rees: The Factorial Ecology of Metropolitan Chicago, 1960. Unpublished M. A. thesis, University of Chicago, 1968.

10 Dовотнy N. Kaufman of the U.S. Bureau of the Census, Socio and Economic Statistics Administration communicated this information by letter, September 4, 1973.

11 Albert J. Rerss, Jr.: Occupations and Social Status. Glencoe: Free Press, 1969; and Arthur H. Wilkins: The Residential Distribution of Occupation Groups in Eight MiddleSized Cities of the United States in 1950. Unpublished Ph. D. dissertation, University of Chicago, 1956. pp. 2-6. 

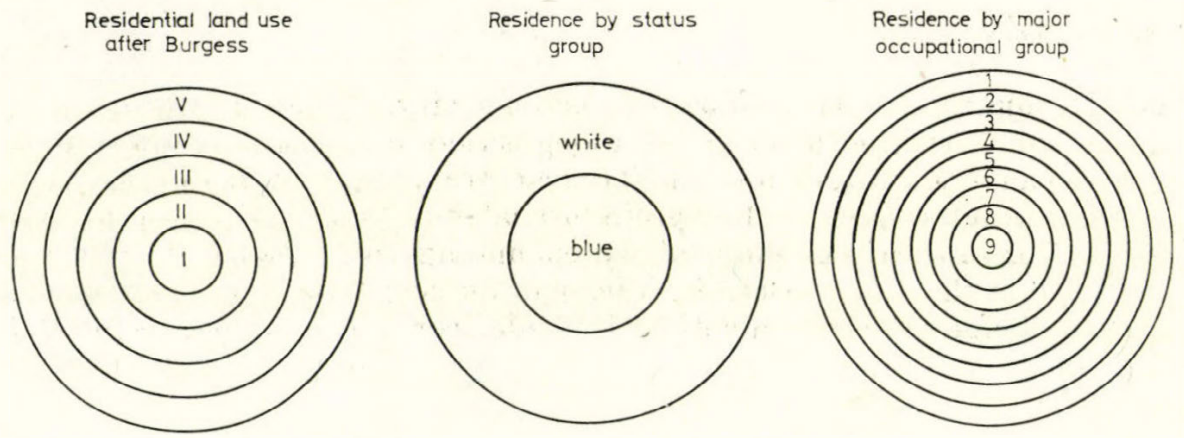

Fig $I$.

Comparison of BuRgess' concentric zones with concentric zones defined by Major Occupational and Status Groups

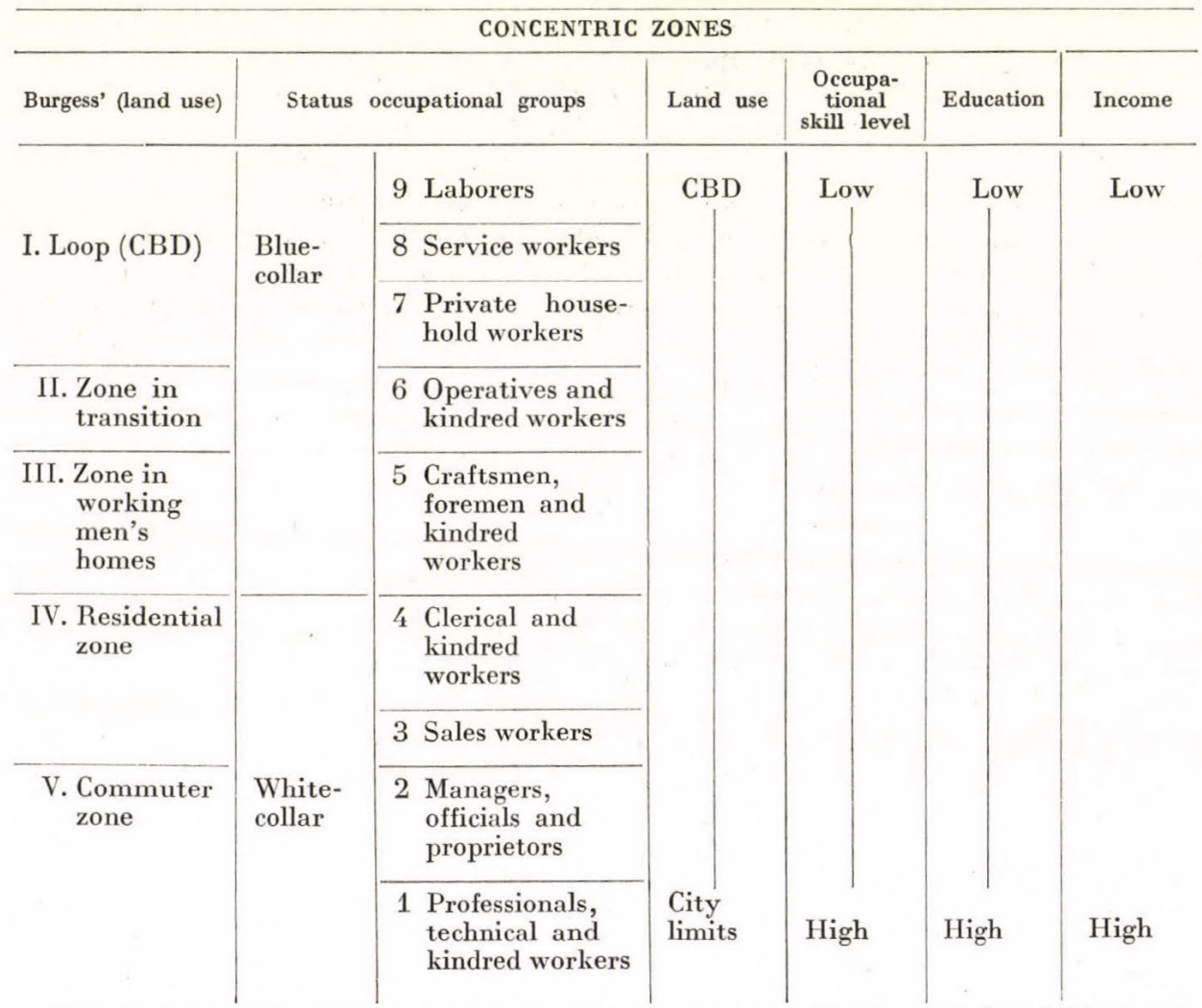

Note: A minor variation from the residential position is to be expected in the private household category. By the nature of their employment private household workers reside at their workplace located in the homes of professionals and managers. Therefore under these circumstances private household workers' residential location may resemble that of their employers.

Source: BURGESs; The Growth of the City, p. 50; EDwARDS; Alphabetical Index of Occupations and Industries Washington, D.C., U.S. Government Printing Office, 1940, pp. 3-5; DUNOAN and DUNCAN;Residential Distribution and Occupational Stratification, p. 493, and WILKINS: The Residential Distribution of Occupation Groups, pp. $25-26$. 
interaction space. ${ }^{12}$ Taking all these factors into account, this study will proceed accepting the assumption that occupation is the dominant factor in determining residential location. If this assumption is acceptable and data are available, then residential areas stratified by occupational groups can be established which are highly correlated with the land use categories outlined in the Burgess hypothesis. The substitution of residential location by occupation fits nicely into the Burgess scheme illustrated in Figure 1.

\section{HYPOTHESIS}

Acknowledging the assumption that occupation strongly influences residential location and that the residential location of the major occupational groups may be substituted for the land use categories outlined by Burgess, it can be hypothesized:

There is a strong relationship between residential areas defined by occupational groups and distance from the central business district (CBD) where low-skilled, e.g. laborers will be generally located near the CBD, and high-skilled workers, e.g. professionals will be located near the city's edge, and all intervening occupational groups' locations will be arrayed at distances from the CBD according to that group's skill level.

\section{DATA}

Data to test the hypothesis are drawn from three sources. The first source from which data are extracted is the city directory. City directories yield information whereby a worker's occupation and residential location can be detemined. For the period 1837-1924 when city directories are the source, probability samples were drawn for the years selected. ${ }^{13}$ Data which is compatible and more easily compiled are drawn from the U.S. Census for the years 1950, 1960 and $1970 .{ }^{14}$ For the year 1953, the Detroit Metropolitan Area Traffic Study provides a set of sample data with compatible specifications. ${ }^{15}$

\footnotetext{
12 Interaction space is that area defined by a person's (or a group's) linkages between residence, workplace and social centers. A full discussion of interaction space can be found in Gary W. Shannon: Residential Distribution and Travel Patterns: A Case Study of Detroit Elementary School Teachers. Unpublished M. A. thesis, University of Michigan, 1965; and Ralph V. Smith, Stanley E. Flory, Rashid L. Bashshur and Gary W. Shannon: Community Interaction and Racial Integration in the Detroit Area: An Ecological Analysis. Mimeographed report, Urban Studies Institute of the University of Cincinatti, 1967.

13 Charles F. Clank's Annual City Directory of the City of Detroit for 1869-1870. Detroit: Charles F. Clark, 1869; Detroit City Directory for 1888. Detroit: R. L. Polk and Co., 1924; James Dale Johnston: Johnston's Detroit City Directory and Advertising Gazeteer of Michigan 1859. Detroit: H. Barns, 1859; Junrus P. Bolrvar MacCabe: Directory for the City of Detroit and Its Environs and Register of Michigan for the Year 183\%. Detroit: William Harsha, 1837; The Daily Advertiser Directory for the City of Detroit for the Year 1850. Detroit: Duncklee and Wales, 1850; and JАсов W. WeEks: Detroit City Directory for 1880. Detroit: Jacob W. Weeks and Ralph L. Polk, 1880.

14 U.S.Bureau of the Census, U.S. Census of Population 1950, Vol. III, Census Tract Statistics, Chapter 17. Washington, D.C.: U.S. Government Printing Office, 1952; U.S. Bureau of the Census, U.S. Census of Population and Housing 1960, Census Tracts, Final Report PHC (1) -40. Washington, D.C.: U.S. Government Printing Office, 1962; and U.S. Bureau of the Census, Census of Population and Housing 1970, Census Tracts, Final Report PHC (1)-58 Detroit, Michigan. SMSA. Washington, D.C.: U.S. Government Printing Office,1972.

15 Detroit Metropolitan Area Traffic Study: Internal Trip Survey. Lansing: Speaker-Hines and Thomas, 1955.
} 


\section{CLASSIFICATION OF OCCUPATIONS}

In the samples drawn from city directories, 403 occupations are identifiable. Under normal circumstances, classification of these occupations into nine major occupational groups would be a nearly impossible task. Using as a guide the Alphabetical Index of Occupations and Industries prepared by ALBA M. EDWARDS which contains 451 occupations arranged into eleven occupational groups, the occupations identified are classified and matched to the nine major occupational categories used by census since 1940. ${ }^{16}$ The match of categories between the Edwards-scheme and census scheme for 1940 and after is shown on Table $I$.

\section{TABLE I}

Major occupational groups

The 11 occupational groups defined by Edwards
Professionals and semi-professional workers

a. Professional workers

b. Semi-professional workers

0 Farmers and farm managers *

1 Proprietors, managers and officials except farm

2 Clerical, sales, kindred workers

a. Clerical and kindred workers

b. Salesmen and saleswomen

3 Craftsmen, foremen, and kindred workers

4 Operatives and kindred workers

5 Domestic service workers

6 Protective service workers

7 Service workers, except domestic and protective

8 Farm laborers and foremen

9 Laborers
The 9 occupational groups used in the study

1 Professional, technical and kindred workers

2 Managers, officials and proprietors, except farm

3 Clerical and kindred workers

4 Sales workers

5 Craftsmen, foremen, and kindred workers

6 Operatives and kindred workers

7 Private household workers

8 Service workers, except private household workers

9 Laborers, except mine

* Farmers are not included in the system used in the study because few farmers reside in the city of Detroit presently nor did they historically.

Source: EDWARDS: Alphabetical Index of Occupations and Industries, Washington, D.C.: U.S. Government Printing Office, 1940 , pp. 3-5; U.S. Bureau of the Census, Alphabetical Index of Occupations and Industries. Washington, D.C.: U.S. Government Printing Office, 1950; U.S. Bureau of the Census, Alphabetical Index of Occupations and Industries. Washington, D.C.: U.S. Government Printing Office, 1960.

16 Alba M. Edwards: Alphabetical Index of Occupations and Industries. Washington, D.C.: U.S. Government Printing Office, 1940. p. 3. The Edwards taxonomic system is closely followed in the U.S. Bureau of the Census, Alphabetical Index of Occupations and Industries. Washington, D. C.: U.S. Government Printing Office, 1960. 
Since the addresses of nearly all workers drawn from city directories are listed, the conversion of these residential locations to coordinates is achieved by superimposing a uniform grid system on the map accompanying each directory, locating the address of each worker selected, then assigning coordinates. This process yields a specific residential location for each worker. The grid system adopted has an interval of 1/20 of a mile (approximately a city block in length). For census tract data, coordinates are assigned to the centroid of each tract using the same grid system. The coordinates determined for each tract are shared as the location of each worker in each occupation category listed for that tract. This conversion is necessary so that the census data which is reported in quadrant form can be compared with the point data extracted for city directories. To use the Detroit Metropolitan Area Traffic Study data, it is only necessary to convert its coordinate system to the one used in this study. ${ }^{17}$

\section{METHOD OF ANALYSIS}

As a centrographic technique, the standard deviational ellipse is particularly applicable to the analysis of dispersed point data. By employing this technique, large volumes of point data can be reduced and abstracted into summary measures. The ellipse and its associated set of measures are designed to describe a spatial population in terms of its location as well as its dispersion. ${ }^{18}$

The following descriptive statistics are products of this technique: (1) the mean location of the distribution is reported as the mean $\bar{X}$ and mean $\bar{Y}$ coordinates; (2) the degree of dispersion as a standard distance; (3) the directional orientation of the distribution as the length and angle of inclination of the major axis; (4) the abstract shape of the distribution as the coefficient of circularity; and (5) the spread of the distribution as the area within the ellipse. When these statistical results are plotted graphically, the shape of the ellipse will vary between a circle and a bicircular quartic (Figure 2).

The standard deviational ellipse is an excellent technique to generate statistical measures which describe the central tendencies (summary measures) of an areal distribution. Nonetheless, this technique has one major weakness when it is used primarily as a spatial rather than a purely statistical measure. This drawback is that it does not graphically show the actual expanse of the distribution. Therefore, it is more a statistical than a graphical technique. ${ }^{19}$

17 Detroit Metropolitan Area Traffic Study.

18 Douglass B. Lee, Jr.: Analysis and Description of Residential Segregation: An application of Centrographic Techniques to the Study of the Spatial Distributor of Ethnic Groups in Cities. Unpublished M. A. thesis, Ithaca, New York: Cornell University, 1966, pp. 8-46; and D. Welty Lefever: Measuring Geographic Concentration by Means of the Standard Deviational Ellipse. American Journal of Sociology, XXXIII, No. 1, July, 1926, pp. 88-94.

19 Rashid L. Bashishur, Gary W. Shannon, and Charles A. Metzner: The Application of Three-Dimensional Analogue Models to the Distribution of Medical Care Facilities. Unpublished paper given at the 97th Annual Meeting of the American Public Health Association, Philadelphia, November 12, 1969, pp. 7-8. 


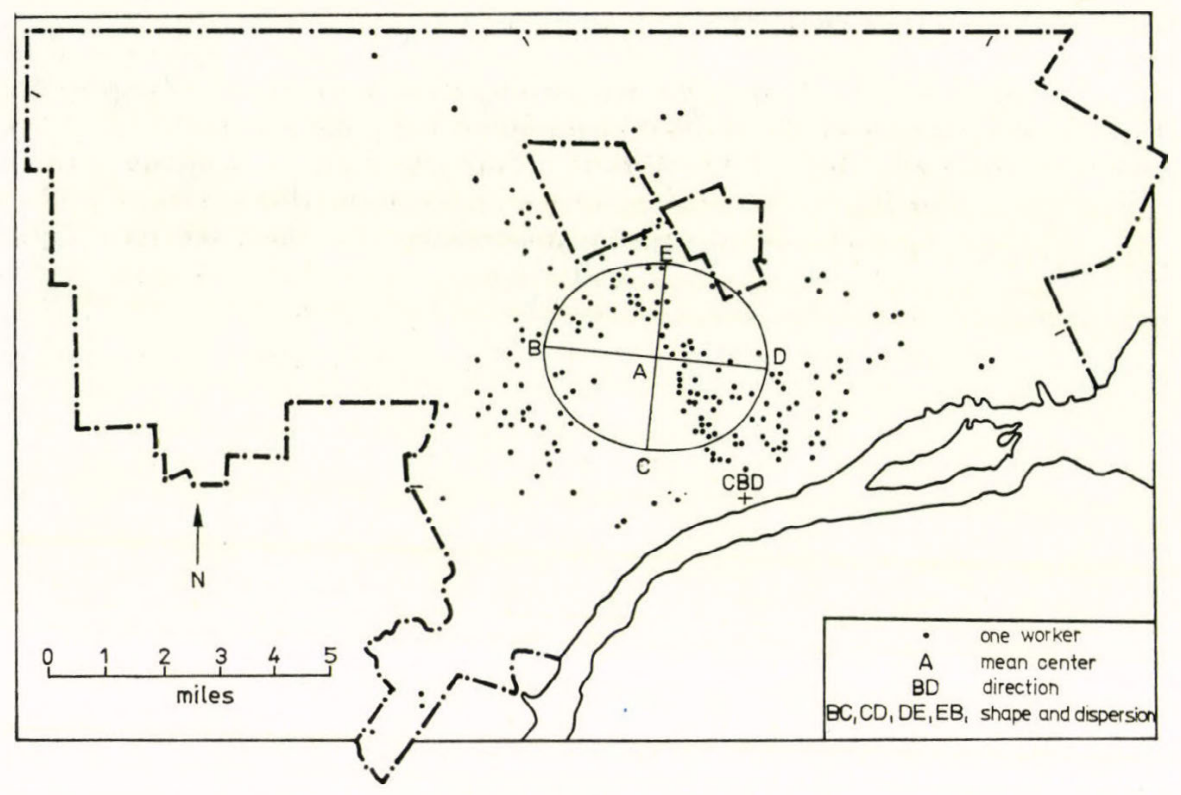

Fig. 2. Standard deviational ellipse, sample occupational group

$1=$ one worker; $2=$ mean center; $3=$ direction; $4=$ shape and dispersion

In order that the continuity and modality which are characteristics of a spatial distribution are properly interpreted, it appears that knowledge of the actual distribution is required. If the summary graphics of the ellipse are superimposed over the actual distribution being measured, then the continuity and modality issues can be better identified and interpreted. Knowledge of the actual distribution will result in a much better analysis of the phenomena being described.

\section{TESTING FOR INTERNAL STRUCTURE}

The graphics and statistics yielded by applying the standard deviational ellipse as an analytical technique are only descriptive. In order to proceed with this study and give these statistics meaning, the summary measures yielded must be interpreted within the context of the study's objective. Some of the statistics which are products of the described technique are used as input to test the hypothesis posed. These statistics must be integrated for each year tested so longitudinal comments on city structure can be made.

By using the standard deviational ellipse, the mean centers of the residence of the nine major occupational groups are calculated for the city of Detroit for each year selected between 1837 and 1970. This technique has been used 
by numerous researchers to deal with location of activities in cities. ${ }^{20}$ It has been specifically used by Douglas Lee in the analysis of residential segregation. ${ }^{21}$ In fact, Lee's application has strongly suggested that this technique is applicable to city structure. Lee calculated the mean residential center for black, ethnic and white (non ethnic) groups residing in selected cities. His results show that for cities of different configurations, black, ethnic and white (non ethnic) respective mean residential centers and their relative distances from the CBD are highly related to status. The further the mean center is found from the city's center, the higher the group's status; a finding which is consistent with the hypothesis of city structure advances by the Chicago school. ${ }^{22}$

Similar results were found for Detroit when using occupation as a basis for stratification, particularly during the period 1950-1970. The mean residential centers of respective occupational groups for the years 1950 and 1960 provide visual evidence that the higher the occupational group status and skill level, the further its mean center is from the CBD. However, when viewing the 1900 and 1910 results, this relationship is not as clear. It is equally clear that the inverse relationship exists when viewing the mean residential centers of respective occupational groups for 1837-1850. It is noted that during this period, the mean residential centers of the higher occupational groups are nearest to the city's center, and the mean residential centers of the occupational groups with lower skills are located near the city's edge. The arrangement of these mean centers for these years suggests a residential pattern similar to that described for Latin American cities and to some extent reflects the preindustrial pattern hypothesized by SJOBERG. ${ }^{23}$ The variations in the patterns comprised of mean residential centers described above are illustrated in Figure 3.

\section{INDEX OF CITY STRUCTURE}

It is obvious that there is a need to find a means by which these differences in the arrangement of mean residential centers of occupational groups for selected years can be compared other than visually. This can be achieved by following the simple model illustrated in Table II. The model ranks each occupational group according to its skill level with the highest skilled occupa-

\footnotetext{
20 Rовеnто BACHI: Standard Distance Measures and Related Methods for Spatial Analysis. Papers and Proceedings of the Regional Science Association, X, 1963, pp. 83-132; BARCLAY GrbBs Jones: The Theory of the Urban Economy: Origins and Development With Emphasis on Intraurban Distribution of Population and Economic Activity. Unpublished Ph. D. dissertation, Chapel Hill: University of North Carolina, 1960; LeE: Analysis and Description of Residential Segregation; Arie Shachar: Some Applications of Geo-statistical Methods in Urban Research. Paper given at Sixth European Regional Science Congress - Vienna, August 29-September 1, 1966; and E. E. Sviatlovsky and Walter Crosby Wells: The Centrographical Method and Regional Analysis. Geographical Revies, XXVII, April, 1937, pp. $240-254$.

${ }^{21}$ LeE: Analysis and Description of Residential Segregation, pp. 1-7, 51-149.

22 Burgess: The Growth of the City.

${ }^{23}$ Schnore: On the Spatial Structure of Cities; and Sjoвerg: The Preindustrial City.
} 


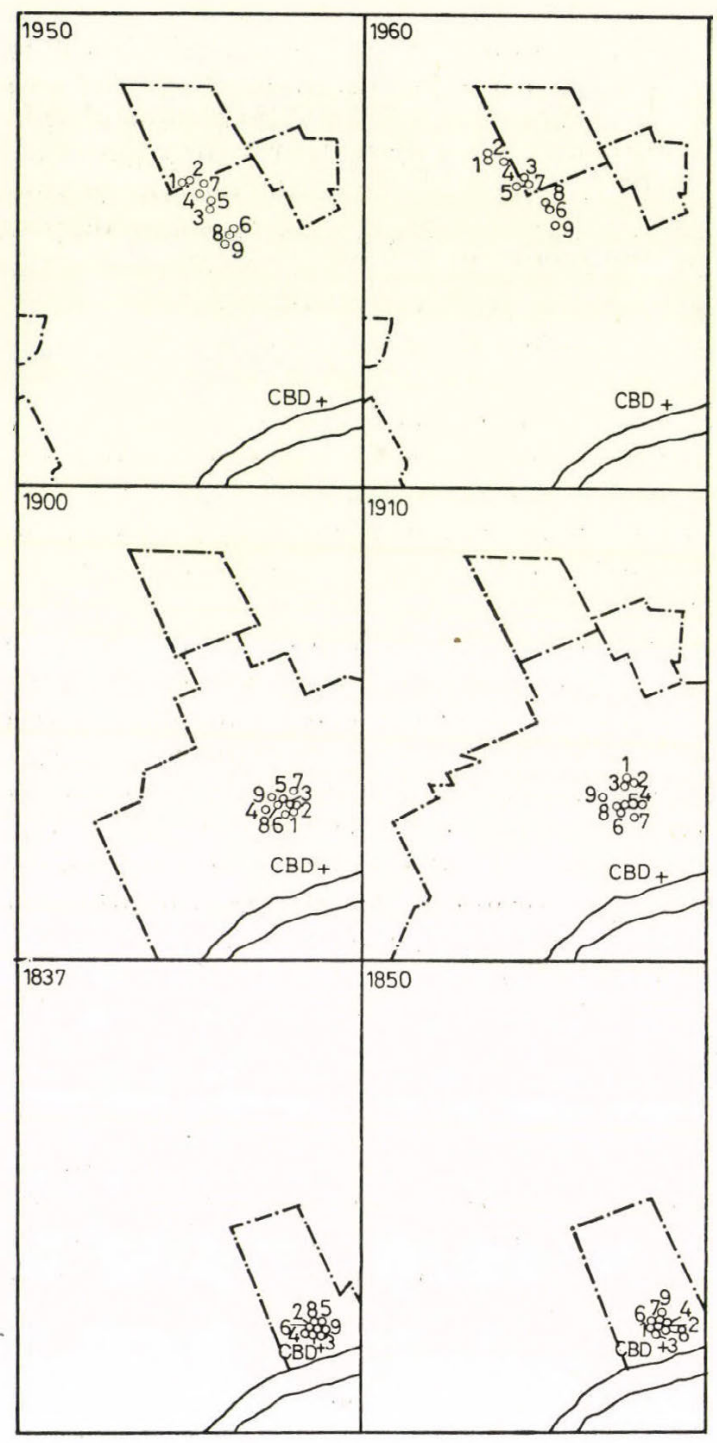

$\frac{123}{\text { miles }}$

Fig. 3. Internal structure for Detroit for selected years

$1=$ professionals; $2=$ managers; $3=$ clerical workers; $4=$ sales workers; $5=$ craftsmen; $6=$ operatives; $7=$ private household workers; $8=$ service workers; $9=$ laborers 
tional group, professionals, being 1 ; the lowest skilled, laborers, being 9 , with all other groups ranked accordingly. The occupational level rankings are found in column 1. By viewing the relative locations of the respective mean residential centers illustrated in Figure 3, it is obvious that these respective centers can be ordered in terms of their relationship to the central business district. The relative distance to the central business district can be ranked and this appears in the model in column two (see Table II). These columns

\section{TABLE II}

Rank-order correlation model describing internal structure of a city

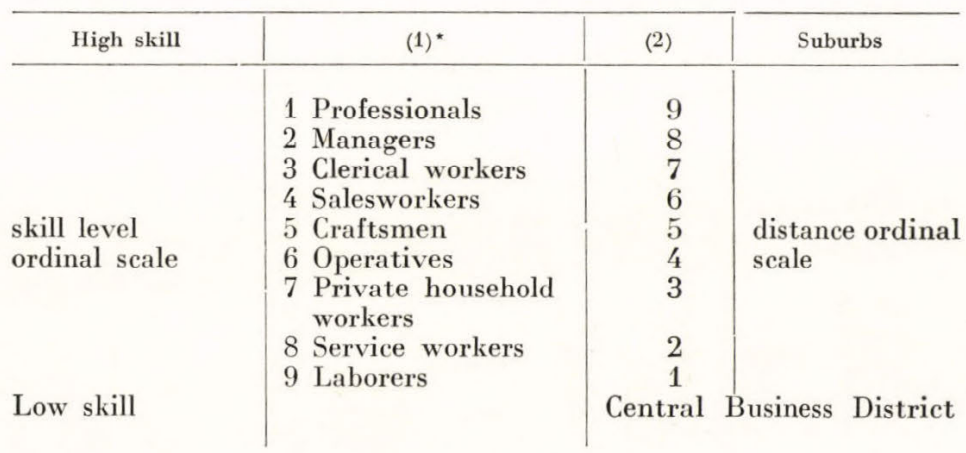

* Rho coefficients of rank-order correlation between (1) ordinally scaled skill level of each occupational group and (2) ordinally scaled distance of mean residential centers to the CBD will range between $+1 \cdot 0$ and $-1 \cdot 0$.

respectively contain the rank of the occupational group's skill level and the ordinal distance that each mean center is from the central business district. Once these data are arrayed in the respective columns, a rank order correlation can be calculated to yield rank order correlation coefficients, ranging between -1 to +1 . When -1 is the result according to the model, this index reflects the structure hypothesized by Bungess, whereas +1 reflects the structure hypothesized by SJOBERG (Figure 4).

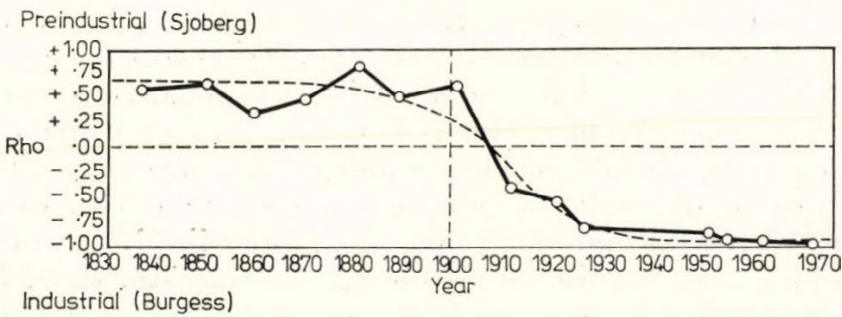

Fig. 4. City structure continuum (Detroit data) 


\section{TEST RESULTS}

The results of the test administered are shown on Table III. A Rho coefficient of rank-order correlation describing the internal structure of Detroit is determined for fourteen times between 1837 and 1970. Table III clearly shows that all the Rho coefficients calculated for the years 1910 and after are negative, suggesting that the industrial structure where workers with high-skilled occupations reside nearest the city's edge prevails. Prior to 1910, the inverse of the industrial structure is the case. Prior to 1910, the positive Rho coefficients suggest that the preindustrial structure dominates.

\section{TABLE III}

Spearman's Rho coefficients of rank-order correlations describing the internal structure of Detroit (1837-1970)

\begin{tabular}{c|c}
\hline Year & Rho \\
\hline & \\
1837 & .554 \\
1850 & .638 \\
1859 & .258 \\
1869 & .498 \\
1880 & $.802^{\star}$ \\
1888 & .504 \\
1900 & .638 \\
1910 & -.437 \\
1919 & -.527 \\
1924 & $-.802^{\star}$ \\
1950 & $-.838^{\star}$ \\
1953 & $-.929^{\star}$ \\
1960 & $-.920^{\star}$ \\
1970 & $-.952^{\star}$ \\
\multicolumn{2}{c}{} \\
5 per cent significance level.
\end{tabular}

\section{CONCLUSIONS}

This experiment strongly reinforces the notion that city structure is dynamic. The results are encouraging because they indicate that an index of city structure can be established and a continuum of city structure can be contemplated.

It is possible to construct a preindustrial-industrial continuum by using all the indices generated. Once this is done, an index for specific years can be viewed as a stage in city structure along the continuum. The potential applications are many, both on cross-sectional and cross-cultural bases if further testing of the continuum is pursued to more firmly establish the index and its usefulness (see Figure 4). In the Latin American case, it is possible to calculate indices based on empirical data to determine the stages of city structure and also determine the rate of change when considering indices 
generated for several years in a time frame. After further testing, it would be possible not only to determine a topology of city structure, but it would also be possible, once trends are established, to predict a city's future internal structure.

If speculation is in order, then city structure for American cities in the future will probably very closely resemble the pattern of residential areas identified for the preindustrial city. Although there will be a change in city size (scale) attributable to possible population growth and areal expansion, it can be

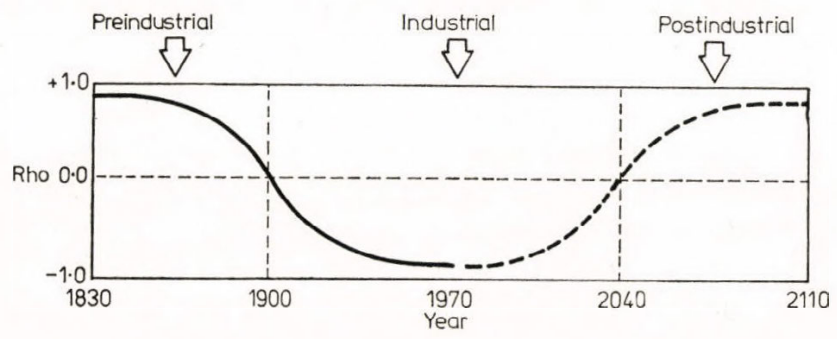

Fig. 5. City structure continuum

hypothesized that the aggregate residential location of workers with high occupational skills will again be located in residential areas that are nearest to the city's center. Perhaps this new city structure can be termed postindustrial (Figure 5). Granted this hypothesis is speculative at best; however, the hypothesized internal structure draws heavily upon interpretation and findings of several earlier studies as well as the trend in city structure identified in this paper. First of all, Jean GotTmann is his book Megalopolis, published in the early 1960's, asserts that the high class residential areas will eventually be reestablished near the city's center in the future. ${ }^{24}$ In addition to Gottman's assertion, the internal structure of the American city may be temporally viewed within the context of invasion and succession which has been advanced by sociologists and by geographers. ${ }^{25}$ The process of invasion and succession which has been observed in American cities has yet not completed a full cycle. Given time, then, it seems logical that the cycle will run its full course. When the invasion and succession cycle is completed, the resulting patterns are viewed, and the change in locations of residential areas for each occupational group is monitored over time, it will probably show that during the course of change eventually each group will relocate in the position where it was when the monitoring was initiated - thus illustrating the completion of the full cycle of invasion and succession.

24 Jean Gotmann: Megalopolis: The Urbanized Northeastern Seaboard of the United States. Cambridge, Massachusetts: M.I.T. Press, 1961.

${ }^{25}$ Burgess: The Growth of the City; Duncan and Duncan: The Negro Population of Chicago; and Derwent Whitrtesey: Sequence Occupance. Annals of the Association of American Geographers, XIX, 1929. 
The fact that urban renewal and model cities programmes have removed older housing in the downtown areas of American cities, and as a byproduct consolidated large parcels of land prepared for development, supports the notion of invasion and succession further, and in fact may be accelerating this change. Generally, when the land is cleared and consolidated through federal programmes, it is usually not developed for its former residents, but rather it is developed for new populations, usually those populations which are better able to afford the higher quality and more luxurious housing built on these sites. An example of this is the Lafayette Park development on Detroit's lower east side where lower density high quality apartment towers and town houses replaced the deteriorating houses formerly characteristic of this area.

Based upon the writing of urbanists, the dynamic nature of city growth and structure, and intuition, as well as the test results establishing the preindustrial-industrial structure for Detroit, it is conjectured that the postindustrial structure will be realized in Detroit and perhaps in other American cities during the early part of the next century, particularly if American cultural attitudes toward property do not drastically change and the quality of new housing does not drastically improve. By looking at the quality of some residential neighborhoods, the notion can be advanced that Americans tend to defer maintenance and utilize their property to a point where it has just about reached a deterioration threshold. At that time, they attempt to dispose of their property at a profit and pass on the accumulated problems which are aggravated by deferred maintenance to the new owner. This method of property disposal is legal and widely practiced. An example of a situation where maintenance has not been deferred can be found in Boston (e.g. Beacon Hill); however, this is an exception to the general case where property is disposed of in the manner described. ${ }^{26}$

Perhaps the best support for this speculation is the test results of this study documenting city structure change in Detroit during the period 1837-1970. Finally, the recent energy crisis will perhaps influence many city dwellers to seek residential locations in central cities to offset increasing transportation costs due to expected gasoline price increases.

Viewing the effects of urban renewal, deferred maintenance and potential impact of the energy crisis in light of the economic filtering theory related to the housing market and the notions of invasion and succession together with the trend in city structure revealed by the index generated in this paper, it is reasonable to hypothesize that in the future the internal structure of American cities will resemble that of the preindustrial city. ${ }^{27}$ Although the pattern will be similar, the reasons for its evolution will be much different. The hypothesis of the postindustrial city illustrates only one application of the preindustrial-industrial city structure continuum identified in this paper.

26 FIREY : Sentiment and Symbolism as Ecological Variables.

27 Wallace F. Smrth: Filtering and Neighborhood Change. Berkeley: University of California, Berkeley, Center for Real Estate and Urban Economies - Institute of Urban and Regional Development, Research Report, No. 24, 1964. 


\title{
METROPOLITAN GOVERNANCE AND SERVICE DELIVERY IN THE UNITED STATES
}

\author{
A Review and Synthesis of Research Findings
}

By

DAVID R. REYNOLDS

\section{HISTORICAL BACKGROUND}

The federal system of government in the United States is often described as highly decentralized. But, as ELAZAR (1972) has argued, this can be a misleading description. The U.S. system differs from a decentralized one in that constitutional limitations are imposed on the extent to which the federal government can concentrate as well as devolve power and functions. Perhaps the best term to describe the formal U.S. system is tri-centric: the territorial centers of formal political authority being the national, state and local governments. Geographically, these levels of government form a hierarchy but in terms of distribution of authority they do not. There is a strong national government, and strong state and local governments, but they share authority both constitutionally and practically. Local units of government have always been important as either administrative units of state government or as providers of basic public services, or both. But, the extension of federal principles to include local governments, particularly cities, is a product of 20th century urbanization.

The term decentralization is descriptive of relationships between state and local governments in the U.S. Historically, local governments owe their origin to, and derive their powers and rights from the respective state governments. This has had the result of introducing a great deal of variation in the structures, size and functions of local governments between states. There is, however, some communality in the general form of state-local decentralization.

First, all states have delegated a great deal of service provision responsibility and/or authority to local governments. For example, the provision of elementary and secondary education, the single largest public expenditure item in the U.S. public economy, is delegated to independent local school districts while the provision of most urban-oriented public services has been delegated to other units of local multi- or limites purpose government.

Second, the delegation of service provision responsibility by states to local governments has also been accompanied, for the most part, by the authority to levy local taxation, primarily on "real" property (land and buildings). Although the national and state governments have increased their flows of revenue to local units, public service provision in metropolitan areas continues to be funded largely through local taxation.

Third, once delegating responsibilities and authorities to local units, state governments have seldom attempted to modify local government boundaries through direct state action. Instead, territorial change has been treated as a local prerogative, albeit constrained by state laws regarding procedure, and sometimes encouraged by state financial and other incentives. 
Throughout the 19 th century American cities were simultaneously political and economic entities. Urban growth was paralleled by the territorial expansion of city jurisdiction. Through annexation, cities expanded to encompass newly settled areas on their peripheries or to secure control over undeveloped land in anticipation of subsequent growth. Residential population density, given the focus of economic activity upon the city's center and the nature of transport technology, remained high even on the periphery of the urbanized area.

By 1900, however, the outward movement of population began to outrun the ability of core cities to enlarge territorially. In particular, the increased geographical mobility associated with the spread of automobile ownership greatly facilitated the expansion of urbanization over more and more land, and permitted the creation of much lower density residential areas. Increased resistance to further core city annexation came from both within and outside core cities. The provision of city services to the newly annexed areas, with their lower population densities, became increasingly expensive. Per capita costs of service delivery, due to systems of taxation, fell disproportionately on existing city residents. For the residents of newly urbanizing areas, incorporation as municipalities politically separate from the core city became an attractive alternative (a) if it appeared likely that local taxation levels would be lower than in the core city, and (b) if the receipts would be sufficient for providing the levels of public services demanded by local residents. A number of other factors were also of import in producing suburban resistance to annexation by core cities. Two of the more frequently mentioned include: the fear of ethnically based big city political systems; and a desire to preserve agrarian values and life styles without sacrificing the advantages of city life.*

State governments in the early decades of the 20 th century also contributed to the formation of suburban cities by enacting legislation prohibiting annexation without the approval of the residents in areas proposed for annexation. Indeed, throughout this century, state governments have played a vital role in creating politically fragmented metropolitan areas. To further enhance local autonomy, states allowed the creation of special districts to provide such services as fire protection, sewage disposal, and water provision; thereby, ensuring the survival of suburban municipalities. Many states established assistance programmes which helped suburbs of small size and limited resources overcome financial deficiencies; and all delegated to municipalities authority over land use and building regulation - authority which is zealously valued under the U. S. system of private property. After World War II, taxation, housing and highway investment policies of the federal government also became significant in increasing the attractiveness of suburban municipalities vis-à-vis central cities and older suburbs both as places of residence and as sites for new industry and commercial activity.

* See Elazar (1972) for a discussion of the anti-city bias in American culture. 


\section{PRESENT PATTERNS OF METROPOLITAN GOVERNANCE}

The present geographical pattern of governance in U.S. metropolitan areas is extremely complex (Table I). The 1972 U.S. Census of Governments reported 22,185 local governments in metropolitan areas, or an average of 84 per area. In metropolitan areas with populations exceeding one million, there is a territorially large and populous central city surrounded, on the average, by 70 politically independent and relatively small suburban municipalities. Overlapping this pattern of municipalities are varying numbers of independent school and other special districts, each with specific tax levying authority and service provision reponsibility. Occasionally, a special district, most commonly an air pollution control or water provision district, will cover an entire metropolitan area. The least densely populated, yet urbanizing, areas within the metropolis which are not within the jurisdiction of a municipality are typically provided urban services through county governments and special districts. Although county governments in the U.S. have traditionally functioned as administrative units of state government and as providers of rural oriented services, those in most metropolitan areas are involved to varying degrees in the provision of urban services to the residents within them. In general, however, the municipality remains the primary unit of local government involved in urban service delivery in metropolitan areas. Municipalities also have control over land use and hence over urban growth.

\section{TABLE I}

Number of local governments in SMSAs* (1972)

and changes in number $(1967-72)$

\begin{tabular}{l|r|r|r|r}
\hline \multicolumn{1}{c|}{ Class of local government } & $\begin{array}{c}\text { Number in } \\
\text { SMSAs, } \\
1972\end{array}$ & $\begin{array}{c}\text { Percentage } \\
\text { of SMS } \\
\text { total }\end{array}$ & $\begin{array}{c}\text { Increase or } \\
\text { decrease in } \\
\text { number } \\
\mathbf{1 9 6 7 - 7 2}\end{array}$ & $\begin{array}{c}\text { Percentage } \\
\text { change } \\
1967-72\end{array}$ \\
\hline All local governments & 22,185 & $100 \cdot 0$ & -56 & $-0 \cdot 3$ \\
Special districts & 8,054 & $36 \cdot 3$ & 485 & $6 \cdot 4$ \\
School districts & 4,758 & $21 \cdot 5$ & -663 & $-12 \cdot 2$ \\
Municipalities & $5 \cdot 467$ & $24 \cdot 6$ & 148 & $2 \cdot 8$ \\
Towns and townships & 3,462 & $15 \cdot 6$ & -23 & -0.7 \\
Counties & 444 & $2 \cdot 0$ & -3 & $-0 \cdot 7$
\end{tabular}

* Standard Metropolitan Statistical Areas.

Source: U.S. Bureau of the Census, Census of Governments, 1972, Vol. 1, Governmental Organization, Washington, D.C.: U.S. Government Printing Office, p. 10.

This highly fragmented and decentralized pattern of metropolitan governance has been the subject of considerable controversy in academic and administrative circles for at least two decades. In the 1950's, the most frequent criticism of the pattern was inherently geographical: the geography of local government was thought too chaotic for the "public interest" for the metropolitan community as a whole to be met. Other problems attributed to the proliferation and layering of local governments were: 
(1) Most local governmental units are too small to realize economies of scale in service provision and hence fail to be maximally efficient.

(2) The large number of governmental units results in needless duplication of service delivery systems and excessively high administrative costs.

(3) Local governments, due to their small size, are parochial and have little incentive to find solutions to metropolitan-wide problems until they reach crisis proportions and, even then, in ways which further contribute to governmental fragmentation.

As BERRY (1973) has emphasized, by the 1960's, urban growth in the U.S. had become largely "self-generated metropolitan growth"; the concentrative process of rural to urban migration typical of earlier decades had virtually ceased. Data from the 1970 U.S. Census of Population indicated that migration on the interregional scale took place primarily between metropolitan areas, while intra-regionally the process of outward migration from central cities and older suburbs to newer suburbs had accelerated greatly in the 1960's. By 1970, the population of suburban municipalities exceeded that of central cities. The structure of governance whereby land use planning and regulation authority rested primarily with the municipality was added by commentators on U.S. urbanization to the ever growing list of factors contributing to the spatially disorderly and socially segregated (by income, race and life style) patterns of suburbanization which accelerated throughout the decade. The fragmented pattern of governance had long been criticized as resulting in geographical mismatches between service needs and taxable resources, but as the older central cities of U.S. metropolitan areas increasingly became the segregated home of the poor, Negroes, and elderly, this issue assumed much greater social and political significance.

The 1960's, however, also produced a new and quite different view of metropolitan governance: that some cities were too large and too bureaucratic to be responsive to the increasingly diverse service demands and needs of their residents. The ethic of consumer sovereignty in the market place and its collective equivalent in the public economy - local autonomy have always been strong in America. In the post World War II period, local sovereignty in urban service provision in suburban areas had been fostered at almost every turn by policies of the federal and state governments, but had been frustrated in central cities. By the late 1960 's, many residents of central cities, for whom the option of migration to suburbia was not a viable alternative, began to demand changes in the spatial and functional organization of central city governance which would render central cities more like suburban municipalities, at least in terms of delivering services to city neighborhoods more in conformance with the demands and needs of their residents (REynolds 1975, WILLTAMs 1973). In short, post-war suburbanization appears to have ensured that the creation of single, integrated metropolitan-wide governments is politically less feasible now than at any time in the past.

Few students of urbanization and government will deny that reform in metropolitan governance is essential for promoting the welfare of an increasingly urbanized society. Nevertheless, social scientists in the U.S. have, until recently, been more prone to describe governmental problems than to engage in analysis upon which to base reform. The U.S. political system is incredibly 
complex and, as indicated above, so too are the political systems of U.S. metropolitan areas. This complexity renders analysis difficult; recent researchers have attempted to grapple with it in different ways. Brief reviews of the empirical and theoretical research pertinent to metropolitan governance follow.

\section{EMPIRICAL RESEARCH: LOCAL GOVERNMENT IN URBAN AMERICA}

The analytical literature on metropolitan governance is a recent literature; one that is growing rapidly. By analytical I mean separating a problem into a set of constituent attributes, elements or subproblems and proceeding by studying the nature of relationships between them. Figure 1 represents an attempt to identify the elements of the "metropolitan governance problem" and the interrelationships which have been singled out by researchers for empirical study and theoretical analysis. It is not meant as a conceptual model or framework which is common to all or even most researchers. Research is too much in its infancy to expect paradigmatic consensus. The figure also represents an attempt to place research in a spatial context. The solid-line arrows symbolize directionality of causal or structural linkages between system attributes as suggested by research, whereas the dashed-line arrows represent informational or policy flows.

Most geographers assume that local governments exist primarily for the delivery of public goods and services to local residents (Cox, 1973, Cox et al. 1974, BARNETT and Mercer 1973, MASSAM 1974). Indeed, this perspective is also dominant in economics (OATES 1972) and common in political science (LINEBERRY and SHARKANSKY 1971). The services delivered should be those which result in higher levels of economic welfare and citizen satisfaction than could be achieved, if they were not provided by governments (TULLOCK 1970). There is also implicit agreement that citizens should play a large role, if not directly in the detemination of what services are provided, to whom, and at what levels, then at least in the selection of representatives who will make such decisions. Beyond this, however, geographers, economists, and political scientists have tended to part company and have focused on different subsets of the attributes and interrelations depicted in Figure 1. There is some evidence of convergence in both empirical research and theoretical research relevant to urban governance (Cox et al. 1974), but it is not yet widespread.

Geographers have tended to focus on the administrative organization of space, the locational decisions of public administrative agencies (e. g. Massam and GoodCHILD 1974, MASSAM 1974) and, to some extent, on the distributional impacts of such decisions (e. g. Cox 1973). Some attention has also been given to conflicts engendered by locational decisions of urban policy makers (WoLPERT et al. (1972), and to the ways in which the political organization of space, itself, affects citizen demands for public goods and services (REYNOLDS, 1975, HAMPSON 1971). Economists have developed a rich theoretical and a small but growing empirical literature focusing upon interrelations between demands 


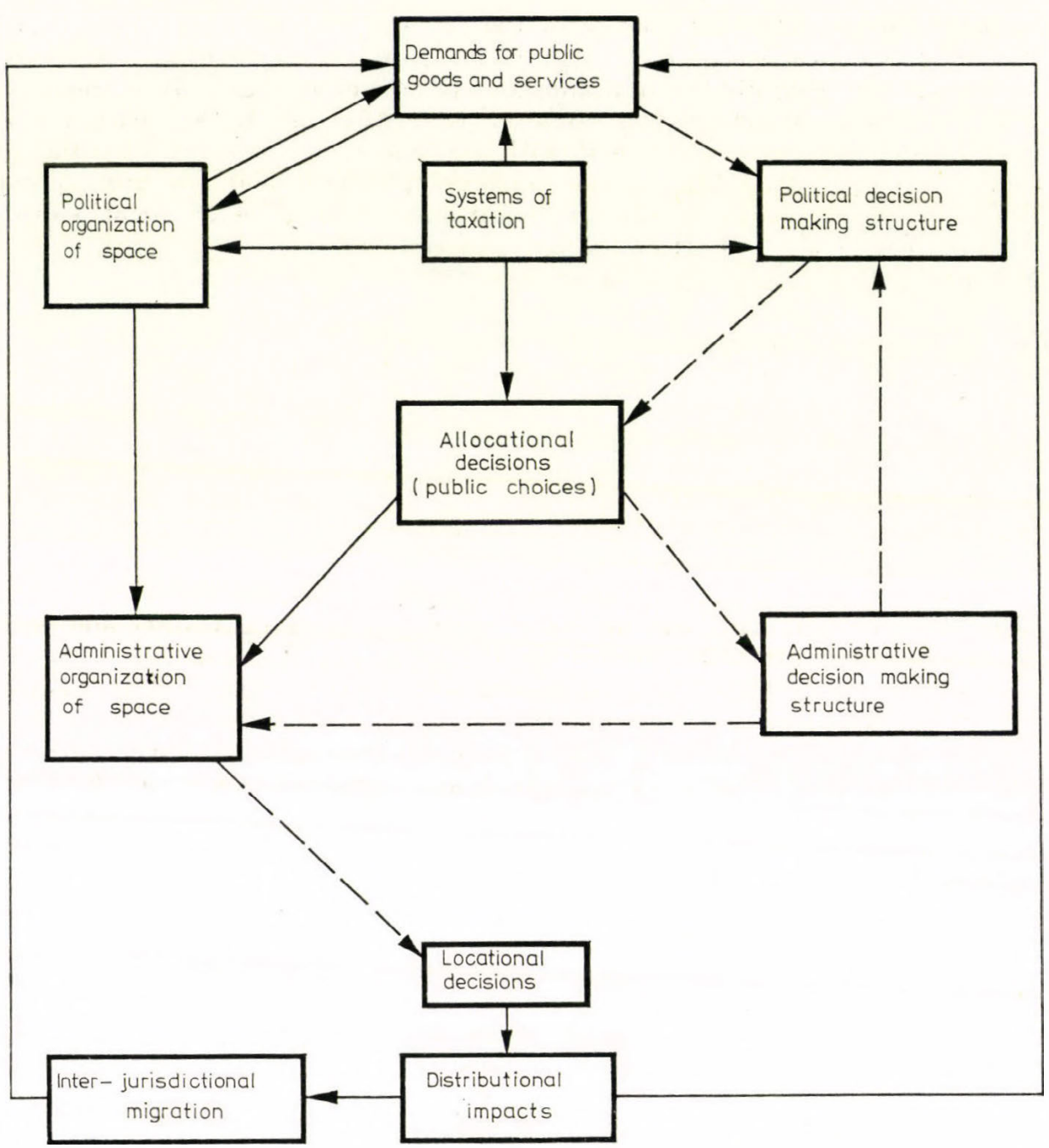

Fig. 1. A framework for the analysis of metropolitan governance

for public goods and services, systems of taxation, the political organization of space, allocational decisions (primarily local public expenditures), and inter-jurisdictional migration (TIEBout 1956, RoTHENBERg 1969, TULLOcK 1969, Buchanan and Goetz 1972, Edel and Sclar 1974, Koleda 1971, McGuire 1972, 1974, Pauly 1970, Ellickson 1971, Oates 1969, Schuler 1974, Olson 1969, Breton 1965). Political scientists have been the most myopic, focusing primarily on linkages between citizens' demands, political decision making, and allocational decisions (again primarily expenditures) (CAMpbell and Sacks 1967, Hawkins 1971). 


\section{Political Organization of Space and Demand Articulation}

Although the political organization of space has emerged as a dominant theme in political geography (SoJA 1971, Cox et al. 1974), little empirical research has been concerned with the ways in which the spatial organization of metropolitan areas into independent political units affects which public service demands are heard and acted upon by local political leaders. That which has been conducted suggests: (1) that large juridisdictions without representation by geographical subareas have much lower levels of participation in local politics by the poor and minority groups (SLOAN 1969); (2) that geographical fragmentation does not necessarily prevent local governments in metropolitan areas from achieving high levels of cooperation in the provision of capital intensive services, such as water provision, sewage disposal, and fire protection (RExnolds 1975); and (3) that the devolution of responsibility for service demand articulation from large to smaller units results in quite different levels of local demands for those services which are labor intensive, e.g. police protection and education (BISH and OsTrom 1973, REYNOLDS 1975). The literature on legislative redistricting, although focusing on partisan preferences, also suggests that the spatial structure of territorial legislative systems can have dramatic effects on electoral results and hence on which public demands produce legislative action (TAYLOR 1973).

In economics a literature has emerged which suggests that more students of local governance should consider not simply the ways in which the political organization of space affects citizen demands for public services, but also how the locational behavior of individuals and firms in a highly mobile society is affected by the range and mix of public services produced by existing governmental units (allocational outputs) and by the systems of taxation available to such units. First, there is empirical evidence which is consistent with the hypothesis propounded by ТтЕвоuт (1956) that households with sufficient private resources to be in the housing market select a political jurisdiction as a place of residence, at least in part, to satisfy their preferences for governmentally provided services, particularly education (OATES 1969, MAYO 1974, BLOom et al. 1974, EDEL and ScLAR 1974). Therefore, there is some indication that public service outputs in local jurisdictions result in a geographical sorting of middle and upper income households into jurisdictions based on shared preferences.

It can be argued then, that if there were no mechanism by which households could be excluded from living in a municipality, other than that imposed by their ability to pay for housing, there may be distinct welfare advantages from having a large number of local service providing jurisdictions in a metropolitan area. It would increase the likelihood that local services in conformance with local preferences would be provided with low levels of internal political conflict.

Second, and unfortunately, mechanisms do exist to exclude households from local jurisdictions and there are fiscal incentives for local political decision-makers to utilize them. The authority of municipalities to regulate land use through local zoning and building codes coupled with a heavy reliance upon property taxation produces an incentive for local governments to regu- 
late land use such that firms and households which produce at least as much (preferably more) local tax revenue as they are likely to necessitate in increased service provision are attracted while others are repelled (HAMштoN 1973, NETZER 1966). Since education is the largest of local expenditures, this socalled "fiscal zoning" tends to take the form of attempts to "zone out" households with large numbers of children or firms which are likely to employ members of such households (GAFFNEY 1973). Given that lower income households in the U.S. tend to have larger families than middle income households, the result, if such fiscal zoning is practiced on a large scale, is a tendency for communities to be differentiated from one another more by income than by preferences for public goods. * HaMmTON et al. (1973) present evidence of this type of income segregation in suburban areas in the U.S. Some authors argue that municipal zoning authority is a cause of such discriminatory behavior (e.g. HaRvey 1972). Doubtless, this is true. But, local zoning and building regulations also perform useful functions, e.g. reducing congestion, and permitting rational local planning, that are non-discriminatory in terms of income. Research undertaken to date suggests that reform focus less on the institution of zoning and political fragmentation per se and more on the systems of revenue generation employed to finance local public service provision. For example, Намштол et al. (1973) also show that income segregation in metropolitan areas receiving progressive state aid to local school districts is only about half as extensive as in areas where such aid is nonexistent. Further evidence in support of this view is provided by REYNOLDS (1975).

Third, there is strong fiscal incentive for the residents in the urbanizing areas in the U.S. to incorporate as a municipality as soon as it appears that the local property tax base is sufficient to produce revenues to meet long-run local service demands through only moderate or low rates of taxation. Incorporation ensures that local land-use controls can be utilized to preserve the tax base. There is every reason to presume that such municipalities will be geographically smaller and less populous than if property taxation were not the pillar of local finance: all that need assured is that there is sufficient non-residential, high-value land in an area to result in low property tax rates for home owners. Such speculation is entirely consistent with the literature on local property taxation in the U.S. and, if valid empirically, would suggest that the large number of independent municipalities in metropolitan areas is, at least in part, an artifact of a medieval system of taxation. This suggestion clearly warrants empirical research.

\section{Scale Economies in Local Government}

Perhaps the largest body of literature pertaining to public services, and certainly the most well known, is that which has attempted to measure economies of scale in their provision. Excellent reviews exist elsewhere (e. g.

\footnotetext{
* Empirically there undoubtedly is some relationship between income and preferences for certain public services, but equally certain is that many preferences are unaffected by income.
} 
HrRsch 1968), so the focus here will be on a synthesis of findings. First, those studies which have attempted to estimate the optimal size of a city from an aggregative economies of scale perspective have arrived at widely differing optime. Hirsch's $(1959,1968)$ estimates, 50-100,000, are at the low end, whereas Hoover's (1971), 200-1,000,000, and DUNCAN's (1956), 500-1,000,000, are at the high end. RICHARDSON (1973) details the methodological difficulties associated with such estimates, so they need not detain us here.

Studies which have attempted to estimate economies of scale for an individual service or a group of similar services have focused primarily on how per capita expenditures vary with city size. Even here, the results have been inconsistent (IIRSCH 1968). One of the few consistencies is that there is evidence of high costs in very small cities, a long flat horizontal bottom to the cost curve indicating a very wide range of "efficient" city sizes, and an exhaustion of economies between city sizes of 100,000 and 250,000. Of course, there are some notable exceptions in those services which, by definition, require that they be undertaken on an area-wide basis or whose provision involves several different levels of government: air pollution control, urban transportation and electric power. Two studies, it should be noted (BRAZER 1959, and Hughes 1967) found no relationships at all between per capita expenditures on municipal services, whereas another (BAHL 1969) found a positive relationship between city population size and per capita expenditures. Almost all studies (e. g. Brazer 1959, Bahl 1969, Hawley 1951, Scott and Feder 1957), however, have found evidence of a positive correlation between per capita city expenditures and population density. This suggests either higher costs of servicing densely populated areas or that the relationship is spurious and reflective of the greater need for social welfare services of persons living in high density, residential environments. Evidence that the latter interpretation is the more correct is provided by Froman (1967).

Although most investigations of scale economies have focused upon city (or metropolitan area) size as a determinant of per capita expenditures, a few have explored the hypothesis that the political fragmentation of metropolitan areas prevents the achievement of scale economies and, hence, increases service provision costs. In a study of the 212 largest metropolitan areas in the U.S., HawkINs (1971) found that governmental fragmentation, as measured by the total number of governmental units per capita, is uncorrelated with per capita direct general expenditures and with per capita expenditures for welfare, sewage disposal, libraries, financial administration, and utilities. Negative correlations with fragmentation were obtained for per capita expenditures for health and hospitals, police and fire protection, sanitation and housing and urban renewal. The only statistically significant positive relationships observed were with per capita expenditures for education and highways. Even after controlling for the effects of "environmental" variables (median family income and percentage of white collar workers, high school graduates, and non-whites), HAwkins found only weak positive correlations between fragmentation and some of these per capita expenditures. Hawkins' analyses clearly refute the commonly made charge that fragmentation increase the costs of local services. One might argue that fragmentation in the presence of interjurisdictional externalities or "spillover", results in "underexpenditure" 
on services, as some economists do (e.g. OLson 1965), but the fact that school and highway expenditures, both of which should result in high "spillovers" of benefits, are positively related to fragmentation would seem to refute this. Studies by BAHL (1969) and CAMPBELL and SACKS (1967), although utilizing more aggregative per capita expenditures, also found no consistent relationship between measures of "fragmentation" and expenditure levels. More recently, OSTROM and PARKs (1973) present evidence that per capita expenditures for police services in U.S. metropolitan areas are strongly and negatively related to the numbers of police departments per 100,000 population. In short, the duplication of service delivery systems in metropolitan areas, resulting from governmental fragmentation, appears not to result in increased service delivery costs and, for some services, may even contribute to cost reductions.

All of the studies mentioned above suffer from an irremediable methodological weakness. The focus on per capita expenditures measures only financial inputs and reveals little information as to how the levels and quality of public services vary with jurisdictional size. Thus empirical relationships between per capita expenditures and jurisdictional size for a given service yield unsatisfactory estimates of long-run average cost functions. To determine such functions, it would be necessary to devise measures which show the influence of scale on the unit costs of providing a homogeneous output. This gives rise to a host of additional methodological problems, the most important of which are: the necessity of calibrating such functions cross sectionally rather than longitudinally; and ambiguities as to how to "cost" or price public goods in the absence of traditional market or quasi-market mechanisms for their exchange (BISH and OsTrom 1973). The literature contains a number of attempts to measure service output (Popp and SEbold 1972, SchmandT and Stephens 1960, Gupta and Hittion 1968, Will 1965), but none have proven to be satisfactory (RICHARDSON 1973). Even if reasonably accurate measures of output (particularly its quality) were determinable, the available evidence indicates that the results would vary so widely from service to service that it would not permit the specification of a single city or even a narrow range of sizes, as optimal from the standpoint of scale economies and diseconomies.

Bish and Wakren (1972) and Bish and Ostrom (1973) argue that for many urban public services scale economies are an irrelevant consideration in determining the optimal size of a political jurisdiction, if it is possible to separate demand articulating units (political organization of space) from producing units (the administrative organization of space). Indeed, in some U.S. metropolitan areas, most notably Los Angeles, this type of separation has already been implemented with apparent increases in efficiency and in citizen satisfaction (REYNC DS 1975). Diseconomies of scale can, therefore, be overcome and the political organization of space need not determine the administrative organization of space (BARNETT and MERCER, 1973). 
Thus far, little mention has been made of empirical research which has investigated possible relationships between citizen demands for public goods and services, political and administrative decision-making structures and the allocational decisions or public choices made by local jurisdictions. Such research exists; it is recent; and it is voluminous. BARNETT (1974) cites approximately 500 studies conducted in political science and sociology since 1965 which directly or indirectly have attempted to explore these relationships. Obviously these studies cannot be reviewed in any detail here. Some of the better collections of papers and/or reviews of such research include Hahn (1972), Crectne (1970), Clark (1968), Sharkansky (1970), FreDERICKSON (1973), HADDEN et al. (1970), HAWKINS (1971), LINEBERRY and SHARKANSKY (1971), and LowI (1969). What makes comparison between these studies difficult is that most authors study single cities and utilize different operational measures of apparently similar theoretical concepts. These are some common threads, however. Most do not attempt to measure citizen demands for public services directly and, instead, assume that such demands are adequately surrogated by certain physical and socio-economic characteristics of the city. Attention is then directed to whether political and administrative system characteristics are important variables in explaining allocational decisions - those concerned with the scope, quality, and quantity of services provided. Usually these decisions are measured in purely budgetary terms typical of research on scale economies. Hence, they are subject to the methodological criticisms mentioned above. To date, most studies indicate that political system attributes, such as the degree of electoral competitiveness, form of city government, type of administration, the number of decision-makers, and the policy preferences of decision-makers, are poor predictors of allocational decision making relative to 'environmental' characteristics. HawkINs (1971) concludes his literature review:

\footnotetext{
"Recent evidence reveals that city environments - especially the diversity of their populations - are important influences on policy. Socio-economic heterogeneity is a factor greatly influencing the structural characteristics of city political systems and their policy output. For example, greater heterogeneity correlates with the retention of politicized institutions and less heterogeneity with the adoption of reformed institutions. These findings suggest that socio-economic heterogeneity indexes competing political interests and that the more numerous the competing interests the more potent the demand inputs for retaining politicized institutions adept at accomodating differences over the services governent has to bestow, and at responding to group demands." (pp. 113-114).
}

At the metropolitan, as opposed to city, scale much less research has been conducted. That which has (e. g. Hawkins and Dye, 1970) has found that jurisdictional fragmentation in metropolitan areas (as measured by the total number of jurisdictions) is a function primarily of the population size of the area, the age of the central city, and the median family income of the metropolitan area. Contrary to the popular literature on the "metropolitan problem", no significant relationships have been found between fragmentation and either central city racial composition, or suburban-central city differences in terms of racial composition, income, occupational status, or educational 
levels. HawkTns and Dye concluded that their data failed to support the hypothesis that the development of independent suburbs, and hence fragmentation, was a consequence of white-middle-class "flight" from central cities.

From a geographical viewpoint, the literature on the allocational decisions of local governments suffers from a failure to deal explicitly with how these decisions are manifested spatially; for example, we remain almost completely ignorant of how cities allocate resources between different neighborhoods (BARNeTt and Mercer 1973). A recent study by Glassberg (1972) of the linkages between voting behavior and capital expenditure budgeting in New York and London indicates that purely electoral considerations, to which elected public officials are supposedly responsive, are less important in accounting for the location of public service eapital expenditures than more purely administrative concerns. However, in a study of St. Louis, Reynolds and ARcher (1975) demonstrate that when capital expenditure proposals must be voted upon favorably by a city's electorate before they can be enacted, political decision makers can be highly sensitive to neighborhood services demands and needs. In short, knowledge of the linkages between locational decision making and the more general allocational decision making remain meager. That concerning only allocational decisions is also ambiguous: some research indicates that in the aggregate, they may be demand-responsive while other research indicates they may be more purely incremental (Davis et al. 1969, Crecine 1968, Sharkansky 1969).

\section{Some Unanswered Questions}

From the foregoing it can be concluded, that the findings of recent research on metropolitan governance which has explored the empirical linkages between the attributes depicted in Figure 1 have been inconclusive. The progress which has been made suggests that any explanation of the spatial organization of U.S. metropolitan areas into spatially fragmented and overlapping jurisdictions will be complex and that one based on historical accident and outmoded laws governing the creation of new juridictions is not only inssufficient, but fails to provide insights upon which institutional reform might be based.

One of the attributes identified in Figure 1 - distributional impacts has not yet been mentioned explicitly. It is known that the conversion of allocational decisions into locational decisions by administrative agencies of government (local, state and federal) creates a great deal of conflict at the local level. The research conducted by WoLPERT and his associates under the title location of noxious facilities (e. g. MUMPHREY 1970, 1971, MUMPHREY et al. 1971, Reiner et al. 1971, Mumphrey and Wolpert 1973, Cozzens 1972, Austin et al. 1970, WolPERT et al. 1972) provides ample evidence that urban policy makers are both cognizant of the fact that the siting of public facilities produces differential impacts on urban area residents and that facilities are often located so as to minimize public opposition. However, knowledge of the distributional impacts of public policy - how locational decisions affect both income and population redistribution except for highly noxious facilities - remains largely unexplored. 
Rapid advances have made in the development of algorithms by geographers and others for the optimal location of facilities under a wide range of objective functions. ${ }^{\star}$ Most such algorithms are based on considerations of technical efficiency in service delivery from which the short-run, optimal locational patterns of public facilities for serving a dispersed population, with known needs or demands, can be specified. The fact that we remain largely ignorant of distributional impacts of locational policies greatly reduces the conscionable public range of applications to which such models can be put. Such ignorance, of course, stems in part from our present inability to measure with any degree of accuracy the quality of public services. The charge that metropolitan fragmentation, with each jurisdiction pursuing its own local public service delivery policies, leads to socially undesirable cross-jurisdictional, spillover effects remains undocumented and unanswered. Hinman (1971a, 1971b) has developed a number of simulation models for assessing the spatial pattern of costs and benefits of a wide variety of locational configurations of public facilities in urban areas that generate positive or negative external effects. This research appears to provide some methodological guidance, but much remains to be done.

\section{THEORY OF LOCAL GOVERNANCE: PRESENT STATUS}

Despite the fact that there is now widespread agreement amongst American social scientists that local government is a public service providing institution, there is not yet any generally accepted theory of local governance. Although there appears to be a growing realization amongst geographers, political scientists and other students of government of the necessity of such a theory, the partial theories which do exist have been developed by economists. Some have been formalized mathematically (e. g. RoTHENBERG 1970, McGuIRE 1972, 1974, KolEDA 1971) whereas others, although axiomatic, are somewhat less formal (e. g. Tullock 1969, Olson 1969, Buchanan 1965). It is not possible here to do more than point out the common and more general features of these theories so as to provide a glimpse of the general concepts which such writers think useful for subsequent development. ${ }^{\star *}$

In all cases the objective of these theorists has been to deduce certain properties of an "optimal jurisdiction" from the standpoint of the utility maximizing individuals who might inhabit them. A distinction is usually drawn between "private" and "public" goods. The latter consist of goods and services which in consumption exhibit considerable indivisibility or jointness (i. e. one person's consumption does not significantly detract that available from another's consumption) and infeasibility of exclusion (on either practical or ethical grounds). It has long been known that such goods will not be provided at all or not provided at socially optimal levels unless they are provided by government (SAMUELSON 1954, MARgolis 1968). Where these authors differ from classical Pigovian welfare economists is that they argue

\footnotetext{
* For a recent review of this literature see Massam (1974) and LEA (1973).

** For an interesting critique of these theories see HaEfele (1973).
} 
that the services which the economically rational consumer-voter will prefer collectivized will depend on what spatial collectivity (i. e. government) will provide them. Furthermore, it is assumed that the preferences of individuals for public goods are heterogeneous. Most of these authors also assume an equitable distribution of income across individuals (RoTHENBERG 1970 and PAULY 1973, are the significant exceptions) and hence develop much less realistic models than they might otherwise. Usually, it is also assumed that the spatial distribution of individuals with similar preferences for public goods is somewhat clustered rather than random or perfectly intermixed.

From these assumptions and additional ones concerning the financing of service provision and majority voting procedures, it can be deduced that the optimal jurisdiction would be one which satisfies the following minimizationmaximization criteria. First, the delegation of coercive decision-making authority to a territorial constituency should be done in a manner that minimizes the redistributional effects of majority voting within the jurisdiction. Second, the resource cost of producing the public output should be minimized. Third, the "political externalities" across jurisdictions should be minimized. These are viewed as arising whether when the population affected by the policy of a jurisdiction is larger than the jurisdiction's constituency or when the actions of non-constituents can influence policy within the jurisdiction (Rothenberg 1970). Under these highly idealized conditions, the optimal size of a jurisdiction in terms of population and territorial size becomes an empirical problem, albeit one strewn with methodological problems. TULLOCK (1969) argues that additional "costs" should be added to the objective function. For example, since public goods decisions are rarely made through direct citizen voting and more typically through the election of representatives, he suggests that consideration must also be given to minimizing the costs of decision making by voters; minimizing the bureaucratic costs which would arise if each public good were provided through a separate "optimal jurisdiction"; and minimizing the political externalities (including redistributional effects) arising when one jurisdiction provides a large number of public services. Related issues have also been stressed in more traditional political terms. Elazar (1972) suggests that small jurisdictions have distinct advantages in terms of more efficient communication between political leaders and citizens. He argues that the increased cost of such "political communication" associated with urbanization have more than offset the decreased costs of distance. Kochen and Deutsch (1969) make essentially the same point.

Recently several authors (Rothenberg 1969, ELLICKSON 1971, Schuler 1974) have begun to explore the theoretical linkages between the "theory of optimal jurisdiction", and Tiebout migration model, and urban rent theory. Such a convergence in theory development, if it materializes, could provide the much needed theoretical guidance for empirical research. At present, theories are so patently "partial" as to be of little assistance in suggesting which hypotheses are most in need of empirical test. 


\section{CONCLUSION}

The general conclusion reached by most researchers, on the basis of available empirical evidence and theoretical speculation, however, inconclusive is that fragmentation per se is not a problem in U.S. metropolitan areas; what are probably needed, in addition to property tax reform, are more regional governmental bodies making public choices regarding regional service delivery problems and more, not fewer, local governments to cope with neighborhood service delivery matters. A point worth mentioning in conclusion is that on a per capita basis metropolitan areas in the U.S. are considerably less fragmented politically than non-metropolitan areas. In 1972 there was one governmental unit for every 6,458 persons living in metropolitan areas and one for every 1,070 persons residing elsewhere.

\section{REFERENCES}

Austin, M., Smith, T. E. and Wolpert, J. (1970): The Implementation of Controversial Facility-Complex Programs. Geographical Analysis, 2 (October), 315-319.

Bahl, R. W. (1969): Metropolitan City Expenditures: A Comparative Analysis. Lexington, Kentucky, Kentucky University Press.

Barnett, J. R. (1974): Political Structure, Urban Spatial Organization and the Delivery of Municipal Services. Exchange Bibliography No. 507, Monticello, Illinois: Council of Planning Librarians.

Barnett, J. R. and Mercer, J. (1973): Urban Political Analysis and Nesw Directions in Political Geography. Iowa City, Iowa: University of Iowa, Department of Geography, Discussion Paper No. 22.

Berry, B. J. L. (1973): The Human Consequences of Urbanization. New York, St. Martin's Press.

Bish, R. L. and Ostrom, V. (1973): Understanding Urban Government. Washington, D.C., American Enterprise Institute for Public Policy Research.

Bish, R. L. and Warren, R. (1972): Scale and Monopoly Problems in Urban Government Services. Urban Affairs Quarterly, 8 (September), 97-122.

Bloom, H. S., Brown, H. J. i.nd Jackson, J. E. (1974): Residential Location and Local Public Services. Paper presented at a joint conference of Resources for the Future and the Academy for Contemporary Problems, WVashington, D.C.

Brazer, H. E. (1959): City Expenditures in the United States. New York: National Bureau of Economic Research.

Breton, A. (1965): A Theory of Government Grants. Canadian Journal of Economics and Political Science, 31 (May), 175-187.

Buchanan, J. M. (1965): An Economic Theory of Clubs. Economica, 32 (February), 1-14.

Buchanan, J. M. and Goetz, C. J. (1972): Efficiency Limits of Fiscal Mobility: An Assessment of the Tiebout Model. Journal of Public Economics, 1 (February), 25-43.

Campbell, A. K. and Sacks, S. (1967): Metropolitan America: Fiscal Patterns and Governmental Systems. New York, Free Press.

Clark, T. N. (ed.) (1968): Community Structure and Decision-Making: Comparative Analyses. San Francisco, Chandler.

Cox, K. R. (1973): Conflict, Power and Politics in the City: A Geographic View. New York, McGraw-Hill.

Cox, K. R., Reynolds, D. R. and Rokkan, S. (eds.) (1974): Lecational Approaches to Power and Conflict. New York, Halstead Press.

Cozzens, W. A. (1972): Client-Focused Policy Research : Identifying Slippage in a Hierarchy of Governments. University of Pennsylvania, Regional Science Department, Discussion Paper No. 18.

Crecine, J. P. (1968): Government Problem Solving: A Computer Simulation of Municipal Budgeting, Skokie, Illinois, Rand McNally. 
Crecine, J. P. (ed.) (1970): Financing the Metropolis: Public Policy in Urban Economics. Beverly Hills, Calif., Sage.

Davis, O., Dempster, M. A. H. and Wildavasky, A. (1969): A Theory of the Budgetary Process. American Political Science Revies, 60 (September), 529 - 547.

Duncan, O. D. (1956): The Optimum Size of Cities. In J. J. Spengler and O. D. Duncan (eds). Demographic Analysis, New York, Free Press. 372-385.

Edel, M. and Sclar, E. (1974): Taxes, Spending, and Property Values: Supply Adjustment in a Tiebout-Oates Model. Journal of Political Economy, 82 (September/October), 941-954.

Elazar, D. J. (1972): Population Growth and the Federal System. In A. E. K. Nash (ed.): Governance and Population: The Governmental Implications of Population Change. Washington, D. C., U.S. Commission on Population Growth and the American Future, Vol. 4, $25-57$.

Ellickson, B. (1971): Jurisdictional Fragmentation and Residential Choice. American Economic Review, 61 (May), 334-339.

Frederickson, G. (ed.) (1973): Neighborhood Control in the 1970's. New York, Chandler.

Froman, L. A. (1967): An Analysis of Public Policies in Cities. Journal of Politics, 29 (February), 94-108.

Gaffney, M. (1973): Tax Reform to Release Land. In M. Clawson (ed.): Modernizing Urban Land Policy. Baltimore, Johns Hopkins University Press, 115-151.

Glassberg, A. (1972): The Linkages Between Urban Policy Outputs and Voting Behavior: New York and London. Paper presented at the 1972 Annual Meeting of the American Political Science Association, Washington, D.C., September, 5-9.

Gupta, S. P. and Hutton, J. P. (1968): Economies of Scale in Local Government Services. Royal Commission on Local Government in England, Research Studies, No. 3.

Hadden, J. K., Masotti, L. H. and Larson, C. J. (1970): Metropolis in Crisis : Social and Political Perspectives. Itasea, Illinois, E. A. Peacock.

Haefele, E. T. (1973): Representative Government and Environmental Management. Baltimore, Johns Hopkins University Press.

Hahn, H. (ed.) (1972): People and Politics in Urban Society. Beverly Hills, Calif., Sage.

Hamilton, B. W. (1973): Property Taxation's Incentive to Fiscal Zoning. In G. F. Peterson (ed.): Property Tax Reform, Washington, D.C., The Urban Institute, 125-139.

Hamilton, B. W., Mills, E. S. and Puryear, D. (1973): The Tiebout Hypothesis and Residential Segregation. Working Paper 1207-20, Washington, D.C., The Urban Institute.

Hampson, A. (1971): The Influence of Territorial Shape on Municipal Expenditures: England and Wales. University of Denver, Department of Geography, M. A. thesis.

Harvey, D. (1972): Society, The City and the Space-Economy of Urbanism. Commission on College Geography, Resource Paper No. 18, Washington, D.C., Association of American Geographers.

Hawkins, B. W. (1971): Politics and Urban Policies. Indianapolis, Bobbs-Merrill.

Hawkins, B. W. and Dye, T. R. (1970): Metropolitan 'Fragmentation': A Research Note. Midwest Review of Public Administration, February, 17-24.

Hawley, A. H. (1951): Metropolitan Population and Municipal Government Expenditures in Central Cities. Journal of Social Issues, 7 (Winter), 100-108.

Hinman, J. (1971a): A Location Model For Public Facilities with Neighborhood Effects. University of Pennsylvania, Regional Science Department, Discussion Paper No. 13.

Hinman, J. (1971b): Toward a Spatial Strategy for Urban Renewal. University of Pennsylvania, Regional Science Department, Discussion Paper No. 15.

Hirsch, W. Z. (1959): Expenditure Implications of Metropolitan Growth and Consolidation. Review of Economics and Statistics, 41 (August), 232-241.

Hirsch, W. Z. (1968): The Supply of Urban Public Services. In H. S. Perloff and L. Kingo (eds): Issues in Urban Economics, Baltimore, Johns Hopkins University Press, 477-525.

Hoover, E. M. (1971): An Introduction to Regional Economics. New York, Alfred A. Knopf.

Hughes, J. T. (1967): Economic Aspects of Local Government Reform. Scottish Journal of Political Economy, 14, 118-137.

Kochen, M. and Deutsch, K. W. (1969): Toward a Rational Theory of Decentralization: Some Implications of a Mathematical Approach. American Political Science Revies, 63 (June), $734-749$.

Koleda, M. S. (1971): A Public Good Model of Governmental Consolidation. Urban Studies, $8(2), 103-110$. 
Lea, A. C. (1973): Location-Allocation Systems: An Annotated Bibliography. University of Toronto, Department of Geography, Discussion Paper No. 13.

Lineberry, R. L. and Sharkansky, I. (1971): Urban Politics and Public Policy, New York: Harper and Row.

Lowi, T. J. (1969): The End of Liberalism: Ideology, Policy, and the Crisis of Public Authority. New York, W. W. Norton.

McGuire, M. (1972): Private Good Clubs and Public Good Clubs: Economic Models of Group Formation. Squedish Journal of Economics, 74 (February), 84-99.

McGuire, M. (1974): Group Segregation and Optimal Jurisdictions. Journal of Political Economy, 82 (January/February), 112-132.

Margolis, J. (1968): The Demand for Urban Public Services. In H. S. Perloff and L. Wingo (eds). Issues in Urban Economics, Baltimore, Johns Hopkins University Press, 527-574.

Massam, B. H. (1974): Political Geography and the Provision of Public Services. In Progress in Geography, 6, 179-210.

Massam, B. H. and Goodchild, M. F. (1974): The Evolution of Territorial Organization: A Case Study. In Cox, K. R., Reynolds, D. R. and Rokkan, S. (eds): Locational Approaches to Posper and Conflict. New York, Halsted Press, 141-172.

Mayo, S. K. (1974): Local Public Goods and Residential Location. Paper presented at a joint conference of Resources for the Future and the Academy for Contemporary Problems, Washington, D.C.

Mumphrey, A. (1970): The New Orleans Riverfront Expressway Controwersy: An Analytical Account. University of Pennsylvania, Regional Science Department, Discussion Paper No. 1.

Mumphrey, A. (1971): The Pennsylvania Planning-Opposition Simulation. University of Pennsylvania, Regional Science Department, Discussion Paper No. 9.

Mumphrey, A. and Wolpert, J. (1973): Equity Considerations and Concessions in the Siting of Public Facilities. Economic Geography, 49 (April), 109-121.

Mumphrey, A., Seley, J. E. and Wolpert, J. (1971): A Decision Model for Locating Controversial Facilities. Journal of the American Institute of Planners, 37 (November), 397-402.

Netzer, D. (1966): Economics of the Property Tax. Washington, D. C., Brookings Institute.

Oates, W. E. (1969): The Effects of Property Taxes and Local Spending on Property Values: An Empirical Study of Tax Capitalization and the Tiebout Hypothesis. Journal of Political Economy, 77 (December), 957-971.

Oates, W. E. (1972): Fiscal Federalism. New York, Harcourt Brace.

Olson, M. (1965): The Logic of Collective Action: Public Goods and the Theory of Groups. Cambridge, Mass., Harvard University Press.

Olson, M. (1969): Principle of Fiscal Equivalence. American Economic Resies, 59 (May), $479-487$.

Ostrom, E. and Parks, R. (1973): Suburban Police Departments: Too Many and Too Small? In Massotte, L. H. and Hadden, J. K. (eds): The Urbanization of the Suburbs. Beverly Hills, Calif., Sage, 367-402.

Pauly, M. (1970): Optimality, Public Goods, and Local Government: A General Theoretical Analysis. Journal of Political Economy, 78 (May/June), 572-585.

Pauly, M. (1973): Income Redistribution as a Local Public Good. Journal of Public Economics, 2 (February), 35-58.

Popp, D. O. and Sebold, F. D. (1972): Quasi Returns-to-Scale in the Provision of Public Services. Public Finance, 27, 46-60.

Reiner, T., Seley, J. and Sugarman, R. (1971): Citizen Participation in Planning: The Crosstosn Controversy; a Case Study. University of Pennsylvania, Regional Science Department; Discussion Paper No. 12.

Reynolds, D. R. (1975): Progress Toward Achieving Efficient and Responsive Spatial-Political Systems in Urban America. Cambridge, Cambridge University Press, Forthcoming.

Reynolds, D. R. and Archer, J. C. (1975): Locational Logrolling and Citizen Support for Municipal Bond Proposals: The Example of St. Louis. Paper presented at the 71st Annual Meeting of the Association of American Geographers, Milwaukee, Wisconsin, April 21-23.

Richardson, H. W. (1973): The Economics of Urban Size. Lexington, Mass., Lexington Books.

Rothenberg, J. (1969): Strategic Interaction and Resource Allocation in Metropolitan Intergovernmental Relations. American Economic Review, 59 (May), 494-503.

Rothenberg, J. (1970): Local Decentralization and The Theory of Optimal Gevernment. In Margolis, J. (Ed.): The Analysis of Public Output. New York, National Bureau of Economic Research, 31-64. 
Samuelson, P. A. (1954): The Pure Theory of Public Expenditure. Reviesp of Economics and Statistics, 57 (November), 387-389.

Schmandt, H. J. and Stephens, G. R. (1960): Measuring Municipal Output. National Tax Journal, 13 (December), 369-375.

Schuler, R. E. (1974): The Interaction Between Local Government and Urban Residential Location. American Economic Review, 64 (September), 682-696.

Scott, S. and Feder, E. L. (1957): Factors Associated spith Variation in Municipal Expenditure Levels. Berkeley, Calif., Bureau of Public Administration, UCLA.

Sharkansky, I. (1969): The Politics of Taxing and Spending. Indianapolis: Bobbs Merill.

Sharkansky, I. (Ed.) (1970): Policy Analysis in Political Science. Chicago, Markham.

Sloan, L. (1969): Good Government and the Politics of Race. Social Forces, 17 (Fall), 161-175.

Soja, E. W. (1971): The Political Organization of Space. Commission on College Geography, Resource Paper No. 8, Washington, D. C.: Association of American Geographers.

Taylor, P. J. (1973): Some Implications of the Spatial Organization of Elections. Institute of British Geographers, Transactions, No. 60 (November), 121-136.

Tiebout, C. M. (1956): A Pure Theory of Local Expenditures. Journal of Political Economy, 64 (October), 416-424.

Tullock, G. (1969): Federalism: Problems of Scale. Public Choice, 6. (Spring), 19-29.

Tullock, G. (1970): Private Wants Public Means: An Economic Analysis of the Desirable Scope of Government. New York, Basic Books.

Will, R. E. (1965): Scalar Economies and Urban Service Requirements. Yale Economic Essays, 5 (Spring), 3-61.

Williams, B. R. (1973): St. Louis: A City and Its Suburbs. Santa Monica, Calif., Rand, R1353-NSF.

Wolpert, J., Mumphrey, A. and Seley, J. (1972): Metropolitan Neighborhoods: Participation and Conflict Over Change. Commission on College Geography, Resource Paper No. 16, Washington, D.C., Association of American Geographers. 


\section{RESEARCH DIRECTIONS IN URBAN TRANSPORTATION GEOGRAPHY IN THE UNITED STATES}

By

JAMES O. WHEELER

There is one motor vehicle (automobile, truck, or bus) for every 1.7 people in the United States. About 85 per cent of all U. S. families own an automobile, with approximately one-third owning two or more. These add up to nearly 45 per cent of all automobiles in the world. There are now about 100 million registered passenger cars in the United States, compared to 60 million in 1960. These cars, along with trucks and buses, travel an estimated 1.3 trillion miles per year over 3.8 million miles of roads and highways occupying more than 25 million acres of land. Well over 100 billion gallons of fuel are burned annually. Motor vehicle manufacturing, with its enormous appetite for raw materials, is of course one of the major U. S. industries (GREENwoon and EDWARDS 1973).

NETzer explained the dominance of the private automobile in the U. S. by considering urban transportation as comprised of three separate markets (NETZER 1970):

1. People who use public transportation for all trips they take.

2. People traveling to work or to the central business district who have a choice between the automobile and some other mode of transportation.

3. People with a choice of modes who are neither commuting nor traveling to the central business district.

The first market contains a comparatively small number of people, largely living in the central city on low incomes and not owning an automobile. The second market, in which there is direct competition between public and private transportation, is typically dominated by the private automobile, since compared to public transit it is faster, more comfortable, and spatially and temporally more flexible. Psychologically, most travelers apparently prefer to drive rather than ride with strangers. The third market, involving travel during off-peak hours when automobile traffic congestion is not as severe, is easily dominated once again by the private automobile. Hence the public transit system has not proven of widespread competitive advantage in general in the United States, both a cause and a consequence of the long-term highway building programme of federal and state governments (SMERK 1965, 1974).

Geographic research in urban transportation has greatly accelerated in recent years in the United States with the growth of urban population and the accompanying transportation problems. Although the basic methodologic and philosophic approaches to urban transportation geography remain characteristic of the field of transportation geography in general, the considerable research efforts focused on the city permit a review of the theoretical 
and empirical studies within an urban context. Transportation problems have been intensified with urban development, as transportation has itself helped mold that development. Huge sums of money have been spent by the federal, state, and local governments to maintain and improve transportation facilities and services in urban areas. Lesser, though not insignificant funds, have been spent on a wide variety of research investigations to assist in the understanding and the planning of urban transportation.

Several recent publications point up the increasing emphasis in geographic research on urban transportation problems. MuLLeR (1971) in his review of the spatial analysis of transportation identified urban transportation as an important new direction in transportation geography. A number of recent books in urban geography give prominance to transportation, one of the best treatments being BERRY and HorTon (1970). Under the topic of movement in urban areas, the authors focused on urban transportation, planning and technology, transportation demand, trip generation models, trip distribution and urban travel behavior, household travel behavior, the systems approach to urban transportation, and the future of urban transportation planning. Herbert, in his Urban Geography: A Social Perspective (1973), commented that "although social geographers have always included mobility in their study of cities, it has only recently been afforded the kind of emphasis it deserves".

In transportation geography, a growing number of studies deal with urban applications, examples, and experiences. In 1968 HoRTON noted in the preface to his edited monograph that increasingly more attention is being given to urban transportation and that "intra-urban transportation and the problems that plague urban circulation are legitimate and necessary concerns of geographers". HuRsT (1974) devoted substantial space in his collection of readings to the urban transportation theme. ${ }^{\star}$ MULLER, in a synthesis of recent research developments in social transportation geography, focused to a considerable extent on metropolitan transportation. A recent series of essays by WHEELER (1974) also deals with selected themes in urban circulation. ${ }^{\star *}$ Finally, MAYER $(1963,1969)$ has provided some valuable general statements on the relationships between transportation and urban geography.

The relationships between transportation and urban geography may be traced back to the studies of JEFFERSON (1928), who emphasized the functional ties between interurban growth and the transportation network. HaRRIS and ULLMAN in their general classification of urban settlements (1945) identified transport-based cities, along with central places and specialized-function towns. Studies of the internal spatial structure of American cities, by BuRGESS (1925), Hoyt (1939), and HARRIS and ULLMAN (1945), were closely tied to assumptions regarding the relationships between land use and transportation. A study of these relationships over the years has been maintained as evidenced in textbooks in urban geography, such as by MURPHY (1966) and by YEATES and GARNER (1971). In his review of the research frontiers in urban geography,

* See also the recent book by J. C. Lowe and S. Moryadas: The Geography of Movement. Boston: Houghton Mifflin, 1975.

** See also W. Owen: The Accessible City. Washington, D.C.: Brookings Institution, 1972. 
BERRY identified the "relations between urban patterns and transportation systems" as one of the five major substantive topics of urban geography (BERRY, 1966). The findings of these studies, he concluded, were that "the main effect of transport improvements on the system of cities is to increase the competitive advantage of larger centers versus smaller centers" and that "the principal effect on the internal pattern of cities is to facilitate sprawl on the one hand and specialization on the other" (BERRY 1966, p. 415).

\section{PURPOSE AND SCOPE}

With these general background comments in mind, the major objective of this paper may be identified as seeking to synthesize the theoretical and methodological results of recent research in urban transportation geography in the United States. Specifically the focus will be largely on the social aspects of urban transportation. Three particular themes will be developed: (1) individual travel behavior, (2) locational impact of transportation facilities, and (3) transportation and minority groups. Following comments on these research themes in urban social transportation, areas of remaining challenge for significant research in urban transportation geography are identified. Four areas of research challenge noted are (1) applied spatial research and planning, (2) transit location and flows, (3) energy and transportation, and (4) freight flows in the city.

No attempt is made to present in detail the content of the research in the selected themes. Moreover, the themes developed here by no means exhaust the coverage of urban transportation, and the challenges, though significant, are not the only ones confronting the student of the American metropolis. Two complementary surveys of urban transportation research may be noted. The first, "Transportation Research: Problems and Prospects", by ALLen and Boyce (1974), presents recent developments and some historical perspective in the development of urban passenger transportation models. Much of their commentary is of the shortcomings in the use of "large, long-run, predictive computer models for determining future transportation needs and requirements for a period 10 to 30 years beyond a base year" (AlLEN and Boyce 1974, p. 22). The second overview, "Trends in Urban Transportation", delineates certain technological changes in transportation in the city (NoTEss 1973).

\section{THEMES IN URBAN SOCIAL TRANSPORTATION GEOGRAPHY}

\section{BACKGROUND}

Impetus in the study of urban transportation geography in the 1950's came from a variety of sources, the foremost being from location theory and from statistical and mathematical methods. In this sense, urban transportation research has long been in the mainstream of geographic research. TAAFFE $(1956,1962,1963)$ and GARRISON $(1959-1960,1965)$ were important early 
figures in the developing research foundations of urban transportation, the former for studies of air transportation and the journey to work and the latter for a range of studies from highway impact to the application of linear programming and graph theory to transportation research (GARRISON et al. 1959). An overview of the research during the 1950's and 1960's is provided by WHEELER (1971a), who described three interrelated major research foci as an analysis (1) of networks, their location, structure, and evolution; (2) flows on transportation networks; and (3) the significance and impact of networks and flows on the space-economy. (An earlier overview is described by ULLMAN 1954.).

In the mid-to-late 1960's a growing concern in human geography in the United States was with behavior. It was recognized that many of the assumptions in the expanding body of location theory were at variance with human behavior and that, although location theory allowed a comparative base for empirical studies, an improved theory of location was needed which directly incorporated human behavior. Also during this time, considerable stress was being placed on research relevance and activism. In Taaffe's summary of this changing perspective, he noted that the dominant view in geography during the 1960 's "has led to more cumulative generalizations and increased cooperation with other social sciences, but has also been felt by some to have been associated with an overemphasis on sterile geometrics and an apparent neglect of pressing social questions. For the seventies it is hoped that geographic research can maintain a reasonable balance between activism and scientism by stressing those emerging generalizations which promise to have the greatest ultimate impact upon society" (TAAFFE 1974). These research concerns with behavior and impact on society are characteristic of human geography in general, here subsumed for the subdiscipline of transportation under the heading "social" (WHEELER 1973). Just as much of the early research in urban transportation geography emphasized the economic parameters, the more recent studies, reviewed here, place particular weight on the social causes and consequences of transportation (GOLLEDGE et al. 1972).

\section{INDIVIDUAL TRAVEL BEHAVIOR}

In contrast with empirical studies deriving generalizations from aggregate travel data, there is a growing research literature treating movement in urban areas from the perspective of the individual traveler. The interest in aggregate travel patterns, in large measure an outcome of models of "social physics", have been widely studied by application of gravity and intervening opportunity models (OLSSON 1965). These models describe spatial patterns of interaction without, however, stressing what spatial processes may underly the observed patterns. The purpose in examining individual travel is to ascertain how and why travel decisions are made. Individuals may have different goals, which result in a varied travel system. Their knowledge of the urban system is normally incomplete and certainly variable among individuals. The place utility one attaches to destinations in the city may be highly variable and may undergo changes through time. 
The background to the studies of individual travel behavior can be traced to the work of the Swedish geographer HAGERSTRAND (1967) and his examination of the receipt and diffusion of information among individuals. His studies of an individual's social communication network, which he found to be attenuated by travel distance, have been extended rather directly to studies of individual travel in urban areas. WOLPERT (1965) developed a methodological perspective for migration which has proven applicable to studies of individual travel behavior in cities. Although any individual exists within an extensive environment, only a limited part of the "environment is relevant and applicable for his decision behavior. The immediate subjective environment or action space is the set of place utilities which the individuals perceives and to which he responds." (Wolpert 1965, p. 163.) Huff $(1960,1963,1969)$, writing in the early 1960 's, also described behavioral facets of shopping travel.

One of the earliest attempts to develop a theoretical approach to individual travel behavior was in a paper by MARBLE in 1960, though not published until 1967. Marble presented certain game-theoretic formulations for the analysis of the complex decision situation of individual travel behavior. Although providing valuable theoretical insight for later studies, the models discussed by MARBLE have proven difficult to utilize in empirical application. In the same volume NySTUEN, drawing upon location theory, related multiplepurpose shopping trips by customers to the arrangement of retail stores in an attempt to present "a geographical theory relating urban travel behavior to the spatial arrangement of urban facilities". Although the attempt to simulate intraurban travel was not very successful, Nystuen (1967) demonstrated conceptually that "travel behavior is in part determined by the arrangement of facilities and in part determines that arrangement".

During the late 1960's and early 1970's, a number of empirical and theoretical statements extended developments in individual travel behavior. MoRRILL and PITTS (1967), for example, generalized upon the findings of MARBLE and NystuEN (1962) on the measurement and derivation of mean information fields. Drawing upon a wide range of measurements of communication and travel over distances, MoRRILL and PITTS viewed individual information fields as unique but at the same time possessing a general form, i.e., chance variation of the general theme. The unique and general information fields had carry over into individual travel behavior. BROwN and Moore (1970), in the context of intraurban migration decisions, brought together the concepts of information flow, cognitive maps, search and learning behavior, and place utility in a process model which closely related to models of intraurban travel. A number of empirical studies, such as MARBLE and BowlBy (1968), Horton and Hulquist (1971), and Hanson and Marble (1971), further elaborated the understanding of individual travel. BLACK (1971) reviewed the gravity model from a behavioral viewpoint.

It remained, however, for HoRTON and REYNoLDs (1971) to bring together comprehensively the various concepts underlying individual travel behavior in a conceptual model of action space. They distinguished among objective spatial structure ("the location of a household relative to the actual locations of all potential activities"); action space ("all urban locations about which the individual has information and the subjective utility or preference he 
associates with these locations"); and activity space ("all urban locations with which the individual has direct contact as the result of day-to-day activities" (HoRTON and REynoLds 1971, p. 37). Within this conceptualization, individual action space was viewed as a formation process in which action space is influenced by the objective spatial structure of the urban environment, length of residence, the cognitive image of urban spatial structure, home location, and travel preferences. In turn this process modell assumes feedback between one's action space and travel preferences, home location, and cognitive image. One's action space directly affects his activity space. In their empirical results they noted that aggregate action space closely reflects objective urban spatial structure. "However, when variations in action space are examined it appeared that within each sample there were subgroups of individuals with internally similar action space which could not be attributed to the respective objective spatial structures." (HoRTon and ReynoLds 1971, p. 47.) The action space formulation of HoRTON and REYNOLDS should aid in empirical analyses of the relationships between spatial behavior and urban spatial structure. One recent example by HIGGS (1975) applies action space to the analysis of spatial behavior patterns at the individual level. Other empirical and theoretical work is needed to extend the understanding of the characteristics and bases for intraurban travel behavior.

One interesting direction taken in the research cluster discussed here under the heading of individual travel behavior is human activity patterns in the city. Literature on this theme has been recently reviewed in a book by CHAPIN (1974), who also describes a conceptual approach to the study of human activity systems. The study of how and where people spend their time in cities directly impinges on the behavioral components of human movement in cities. The underlying assumption is that human activity patterns and urban spatial structure are interdependent. The need for human interaction and the sequencing of activities are key elements in the spatial organization of cities. Frequently activities are sequenced by travel behavior from one place (activity) to another place (activity). The questions being addressed by students of urban activity linkages are how are activities order over time and how are they connected through urban space (CHAPIN 1968, ANDERson 1971, WHEELER 1972). A number of geographers are active in the analysis of timespace budgets in urban research.

\section{IMPACT OF URBAN TRANSPORTATION FACILITIES}

Transportation geographers, planners, transportation engineers, if not the general public, have long recognized that transportation facilities exert a profound influence on the areas they serve (GARRISON et al. 1959). We are accustomed to generalizing, for example, that the railroad made Chicago a major city and that the highway made massive suburbanization possible. An extensive literature documents and supports the pervasive impact of highways, especially freeways, on the surrounding urban landscape ${ }^{\star}$ (WHEE-

\footnotetext{
* For the most complete and up-to-date statement, see Summary and Esaluation of Economic Consequences of Highsay Improvements. National Cooperative Highway Research Program Report, 122, Highway Research Board, Washington, D. C., 1971, 324 p.
} 
LER 1972b). Most of this literature, particularly in the 1950's and early 1960's, focused upon the economic impact of highway location and such factors as land values, commercial development, and manufacturing growth. These represented the more immediate and quantitable features of highway impact. Environmental and social impact was largely overlooked (WEINER and DEÁK 1972, SLoss 1971).

With the surge of interest and concern with social and environmental problems facing American society in the mid-to-late 1960's and spurred by the 1969 National Environmental Policy Act and the 1970 Federal-Aid Highway Act, transportation planning projects were required to include environmental impact statements. ${ }^{\star}$ The suddenness of this shift from virtually no concern for social and environmental impact to one which no doubt seemed to some highway planners as a preoccupation with the "ecological kick" has led to tremendous pressures being placed upon highway planners and administrators. First, there are pressures to meet approaching planning deadlines by hurriedly incorporating statements of social and environmental impact about which "knowledge is meager, the state of the art is primitive, and the experience is slim LAsH (1973)". McConkey (1973) warned, almost bitterly, that "the suddenness with which the ecology issue has been foisted upon the transportation industry and its users has prevented a planned, orderly approach to attacking the alleged problems. Remedies based on expediency have resulted in hodge-podge, shortrun solutions". Secondly, there has been acrimonious public response to proposed urban freeway construction, and projects have been delayed, postponed, and abandoned in a growing number of metropolitan areas because of negative community reaction. As WITHEFORD noted (1973), "More and more writers have found that favorable public response awaits their attacks on highways and highway administrators in the name of ecology."

There are several reasons for the increased public outcry over social and environmental issues in urban freeway construction. They all come down essentially to the question of who benefits and who is harmed by a freeway route. In a study entitled "Incorporating Social and Environmental Factors in Highway Planning and Design", the authors emphasized that "transportation decisions should be based on the principle of equity", since any transportation plan will "impose costs on some and bring benefits to others" (MANHEIM and SuHRBIER 1973).

The concern of the general American public with equity in the planning and provision of transportation service stems from a long period in which the public was not consulted by transportation engineers and planners about

* See Guidelines: Statements of Proposed Federal Actions Affecting the Environment. Council on Environmental Quality, Federal Register, Vol. 36, No. 79, April 23, 1971; A. D. Litrue, Inc.: Transportation and Environment: Synthesis for Action. U. S. Department of Transportation, Office of the Secretary, Washington, D. C., 1971, 69 p.; National Environmental Policy Act of 1969. Public Law 91-190, January 1, 1970; Procedures for Considering Environmental Impacts. Department of Transportation Order 5610. 1A, U. S. Department of Transportation, Office of the Secretary, Washington, D. C., October 4, 1971; and W. D. RuCKFLSHAUs: Transportation and Environmental Protection. Traffic Quarterly, Vol. 27, April, 1973, pp. 173-181. 
decisions directly affecting them (CRATK 1969). As WEBBER (1971) has commented about this period, "transportation investments were seen as primarily capital investments ..., rather than ... transport services"; the purpose of "transportation facilities was seen as connecting geographic places, rather than as connecting people"; and the test of the superiority of one transport facility over another "was least cost, i.e., least input of resources, rather than the largest output of benefits".

The general public outery is also the result of a number of fundamental social changes that have occurred rather dramatically in recent decades in U. S. metropolitan areas. These include the overall growth of urban population, bringing about inequalities in accessibility and congestion; the movement of whites from central city to suburbs and the concentration of blacks in the inner city; "the decay, declining property values, and the declining mobility provided by public transportation in the central cities"; and the suburbanization of jobs and commercial activities. All of these factors accentuate the disparities between life in suburbia and life in the ghettos (WITHERForD 1973, p. 147). These inequalities are inherently geographical, and the inequities in transportation decisions therefore are manifest geographically.

In a recent paper prepared for the United States Department of Transportation, APPLEYARD (1971) identified four major goals for transportation systems in future urban environments. The first two have societal implications for the transportation network and the movement system; the latter two deal with the relationship between transportation and the environment it serves:

1. Spreading transportation service to deprived population groups.

2. Increasing the choice and quality of travel for the whole population.

3. Eliminating or reducing the negative impacts of transportation systems on the social and physical environment.

4. Contributing to environmental quality through transportation planning.

To implement these goals requires careful geographical analysis since a transportation system is distributed unequally areally and therefore its impacts (both desirable and undesirable) are also unequally spread over an area. Ten years ago HoRwoon (1965) cited the "need for a research programme of spatially integrated studies which examine community consequences (of transportation) in the larger context of the metropolis or region . . ."

This challenge remains with us yet today, since "the secondary and tertiary effects of recent highway developments have been far more provocative of citizen protest than either the protestors or the highway builders have realized (WEBBER 1971, p. 6)." It is not simply the highway user impact at one point in time that needs to be better understood, but also the non-user impact in the future. "As individual households and firms adjust their locations to accord with the new accessibility conditions, the freeway generates a secondary wave of outputs - a secondary set of consequences - this time for the metropolitan area's spatial structure. In further turn, modifications in the spatial arrangements of the metropolitan settlement may so change the distribution of opportunities and the incidences of cost among the region's publics as to provoke concerted political protest." (WEBBER 1971). In a study focused on 
Baltimore, GRIER (1971) found, for example, that a proposed freeway routing would accelerate existing downward trends in neighborhood environment in such factors as population size, racial mix, age distribution, income and skill levels.

Transportation planners have been forced to recognize the necessity of involving community groups in the transportation planning process, although there are many quite different approaches to and kinds of citizen participation. Unfortunately, the issue of community involvement in highway route planning raises more questions about the social and environmental impact from transportation than it answers. For example, who speaks for the community? Is there one community viewpoint? Is there even a definable community? To what extent does residential proximity from the proposed highway influence one's attitude toward the anticipated service or toward expected negative features of the facility?

It is possible, however, to generalize about the positive and negative effects of urban highway location, while recognizing the wide spectrum of individual and specific community reaction. While the environmental costs are normally greatest in the area immediately adjacent to the freeway and decline rapidly away from the facility, economic and social benefits are more widely diffused throughout the urban area, even though they also reach their peak near the freeway. Residents living near the freeway benefit through increased accessibility which at least in theory increases the efficiency of the entire urban transport system. However, noise pollution has more definite geographical bounds, as does the environmental impact of construction, neighborhood disruption, or scenic or wildlife destruction. On the other hand, air pollution, though especially concentrated near the freeway, may spread over a wide area.

The strip near the freeway thus bears the greatest environmental costs, and these costs are frequently viewed by community groups as exceeding economic and social benefits. It is surprise then that those in or near the path of a proposed freeway raise the loudest outcry and most bitterly oppose the freeway's construction. The increment in accessibility is not sufficient to overcome the negative social and environmental impact.

There is also a basic conflict between user and nonuser impact (WEINER and DЕÁK 1971). Individuals who use the transportation service provided by the freeway benefit by being located near the facility, and the impact on the user therefore declines with distance away from the freeway. Nonuser impact is manifest in changes in land use as a result of the freeway location or in environmental costs most directly affecting households near the freeway. Although a new highway facility may bring about nonuser economic benefits over a period of time (such as an increase in land value), it also result in negative nonuser environmental impact, especially close to the urban freeway. For an interesting study of neighborhood values based on four Chicago communities, see Rothman (1973).

There is also evidence from attitude surveys that various socio-economic, racial, and demographic groups react differently to the trade-off between the advantages and disadvantages of proposed freeways (BARNES 1967, BLEIKER et al. 1971, Fielding 1968, 1970, Manhern 1971, Mason and Moore 1971, Pendakur and Brown 1969, Wachs 1971, Walton and Saroff 1971). 
This difference is owing to such factors as variation in per capita ownership of automobiles, the value placed on neighborhood stability versus mobility, regional or metropolitan identity versus neighborhood desires. Environmental reaction against proposed freeways may not surface strongly among some groups until the freeway is imminent, the route has been selected, or even the right-of-way has been secured.

Many of these differences relate to the diffusion of reliable information about the proposed freeway and route alternatives. Information transfer is both biased geographically and socio-economically within the city. Whereas even in the recent past urban policy decisions were reached by a select group with a minimum of diverse debate, more and more commonly today many interest groups vie for influence in the decision process. FIELDING has recognized that it is now outmoded to view the choice between alternative transportation proposals as a process of rational decision making. "The politics of participation have introduced new dimensions and our theories on the location of transportation facilities and their impress upon the environment must reflect the competition between groups with conflicting interests." (FIELDING 1970, p. 119). Locating urban freeways is clearly recognized as a political problem.

Community attitudes toward proposed urban freeways point up certain conflicts with transport policy. Conflicts involve regional or metropolitan needs versus local desires, national versus local policy, and mobility versus neighborhood stability. The metropolitan area needs improved transportation, and the benefits of such improvements are diffused. The local neighborhood will receive modest mobility benefits but will bear the most harmful impact of the construction of the transport facility. The urban freeway frequently serves the mobility needs primarily of suburban residents, thereby maintaining their neighborhood stability at the expense of destroying the stability of innercity neighborhoods, which are either physically displaced or fragmented by freeway location. Moreover, since inner city areas tend to have the lowest per capita ownership of automobiles, the residents of the "old" city are least likely to effectively utilize the freeway, whether to gain access to the growing job potential in the suburbs or to move about the urban area for social or commercial purposes. The transit systems in most cities may be similarly criticized, as they make accessible only restricted parts of the metropolitan area (WARD and PAULHUS 1974).

A modest, though nonetheless important, body of literature exists by geographers regarding the impact of transportation facilities in urban areas. This literature may be traced back to the several highway impact studies conducted by GARRISON et al. (1959) some fifteen years ago (GARRISON and Marts 1958). These studies were reviewed by Berry (1959). FIELding (1968) described the process of urban freeway location in terms of resolving community conflict. In contrast to cost-benefit or cost-effective analysis, Fielding proposed value analysis, a subjective ranking of community consequences of alternative freeway aligments which attempts to incorporate community attitudes. MUMPHREY and WOLPERT (1973), in an analysis of bridge siting in New Orleans, recognized that the goals of efficiency and equity are typically in conflict in the delivery of public services, such as transportation facilities. They presented a model "which examines the allocative efficiency 
and spatial equity aspects of alternative bridge sites as well as citizen preference as expressed through the voting process". Of particular interest in their model is the spatial expression of the benefit and loss impact area for neighborhoods. A more general discussion of conflict in the location of public facilities is provided by WoLPERT et al. (1972). AUSTIN (1974) attempted to overcome certain problems in the use of cost-benefit analysis in evaluating the impact of public facilities. He presented a conceptual model which explicitly recognizes "the importance of the spatial distribution of impacts and the fact that tastes can differ substantially among people". Taking a somewhat different approach, Hetrick and CaLkins (1972) undertook a behavioral analysis of election results of an urban mass transit vote in Seattle. They found in the defeat of the transit bond issue that voter response is a function of the economic characteristics of the population and the overall economic state, but that the need for improvements in the transportation system or the projected level of transport service do not influence voter response.

\section{TRANSPORTATION AND MINORITY GROUPS}

Minority groups in American cities confronted with the most severe transportation problems are the blacks, the poor, the elderly, and the handicapped. With the general trend toward interest in societal issues, a number of studies have focused on mobility problems of deprived groups (MuLLER, in press). $\operatorname{KAIN}(1963,1965)$ was among the earliest to demonstrate that black employment opportunities in urban areas were limited because of a spatially restricted housing market and low levels of worktrip mobility. WHEELER (1968) showed that the mean trip length for blacks in Pittsburgh was considerably shorter than for whites, although low income are equally or more immobile than blacks. In another study using Tulsa worktrip data, WHEELER (1969) identified "forced mobility", or the tendency for blacks to travel considerably higher than average distances to find employment outside the Tulsa black ghetto. In perhaps the most comprehensive study comparing worktrip behavior of blacks and whites, DESKINS (1972) studied the changing relationship between residential and workplace location in Detroit from 1880 to 1965 . He observed the impact of residential segregation on black worktrips, focusing particular attention on the social consequences of blacks being forced to travel greater distances to work than the white population. "For those Negroes who used available public transportation, income differentials and longer worktrips required them to contribute a disproportionately large amount of their salary to transportation costs." GREYTAK (1974) also found that blacks in large urban areas spend excessive amounts of time commuting compared to whites.

In a study of perceived transportation needs in a black ghetto, BERNSTEIN (1973) found the greatest gap between transportation needs and available services was for social travel. Access to employment opportunities, especially in the suburbs, was not perceived as very important, probably because of lack of information about the availability of more distant jobs. Just as the ghetto isolates its inhabitants in their spatial mobility within the city for work, shop- 
ping, business, medical, and social travel the ghetto boundary also acts as a severe barrier to the flow of information. Although levels of interaction between the black ghetto and the rest of the metropolitan area are low, interaction intensity within the ghetto is extremely high. It has been suggested that it may be possible to define an urban ghetto on the basis of linkage and flow intensity (WHEELER 1971b). The mapping of black travel patterns gives a visual interpretation to the extent of the ghetto; a mathematical index, such as a ratio of actual to maximum connections, would aid in the delimitation of the ghetto on the basis of linkages and flows.

The federal interstate highway programme has not provided equal access to housing and employment for all segments of the population and has in fact imposed even greater barriers to movement for some (RABIN 1973). The metropolitan freeway has enriched land owners and developers by billions of dollars in increased land values and has thereby added greatly to tax revenues and the amenities derived from these tax dollars. These freeways have had a most substantial impact on the redistribution of metropolitan population and employment, even though decisions on the location of freeways are made with little or no regard to the spatial redistribution of the metropolitan area which invariably results.

The percentage of the central city's black population doubled from 1950 to 1970. Between 1960 and 1970, in the Standard Metropolitan Statistical Areas in the United States of over one-half million population, approximately 1.9 million whites left the central cities to be replaced by over 2.8 million blacks. In contrast, in suburban areas, whites increased by nearly 12.5 million, compared to only three-quarters of a million blacks (RABIN 1973, p. 65).

At the same time that population redistribution was occurring, employment opportunities were also changing. Both commercial and industrial activities are moving to the suburbs at a rapid rate. Blacks are consequently having to chase fewer and fewer low-paying jobs farther and farther into the suburbs. Furthermore, RABIN noted (1973, p. 69) that "central cities are more accessible from the suburbs than the suburbs are from the central cities". Although the freeway in theory connects equally the central city with the suburb, the significantly lower rate of automobile ownership in the central city means that the suburbanites are able to utilize the facility more readily. The public transit systems are generally not designed to move travelers from the innercity to the suburbs, but rather as structured to bring suburban residents to the central city.

Much of what has been said in regard to mobility of blacks also pertains to the urban poor. A basic difference, however, is that the poor, though most likely to reside in the central city, are far more widely scattered throughout the metropolitan area. In a case study of New York, ORnati (1969) argued that "existing public transportation networks in American metropolitan centers of the third quarter of the twentieth century provide an unsatisfactory link between the job sites for and the residences of the poor, forming a barrier to their employment." Generalizing for New York, as well as for other large metropolitan regions, ORNATI noted the following (1969, p. 71):

1. There is a surplus outside the city of low-skilled, low-wage jobs, compared to low-income workers. 
2. Low-income people living outside the city have an even more marked propensity to work in the county of their residence than those in the city.

3. Reverse commuting, i.e., travel to work outside the city, which involves more than ten percent of all heads of house, drops to less than four percent for the low-income population, in spite of the large suburban employment potentials for this group.

4. There is a slow but continuing "scatteration" of low-income households away from the older cities of the region. These problems are examinated more recently in Indianapolis in studies by DAviES (1972) and DAVIES and AlBAUM (1972).

Much less attention has been given to the mobility problems of the elderly. Golant's monograph (1972) pointed up the problems of the elderly obtaining: easy access to necessary facilities, such as medical services. Many of the elderly do not drive and are dependent upon taxi, public transit, or walking. With the relocation of medical services to groups of medical centers and shopping facilities to large-scale shopping plazas, the elderly often feel isolated from necessary services. Moreover, many of the elderly exist on low, fixed incomes; as needed facilities spread ever more widely over the metropolitan landscape, a greater share of the income goes for transportation. The recent rapid climb in fuel cost has had a significant impact on the fixed income elderly, as well as on the low-income household. Markovitz (1971) has ably summarized the mobility needs and problems of the elderly. Several recent papers emphasize geographic implications of the travel behavior of the urban elderly. (For example Wiseman 1975, Hanson and Hanson 1975.)

Even less research has been directed toward the handicapped. There are estimated to be several million U. S. urban residents whose physical handicaps result in mobility limitations. These people cannot use most public transportation, and yet as PERLE (1968) pointed out these are the people in greatest need of public transportation. Included among the handicapped are the blind, the arthritic, the wheel chair individual, and those relying on mechanical walking aids. Because of the considerable vertical component in the city, the handicapped face great impediments to moving about.

The United States Urban Mass Transportation Administration has had a growing impact on finding solutions to some of the problems facing low mobility residents in urban areas. Results thus far, however, have been uneven. As SMERK readily has admitted, "the chances for quick and effective action seem dim when one reflects upon the glacial pace of U. S. developments in mass transportation" (SMERK 1974, p. 216).

\section{CONCLUDING COMMENTS: FUTURE CHALLENGES}

Geographic analysis of urban transportation has been pulled in two seemingly different directions over the past several years. One direction has been toward the theoretical; the other is toward applied problem solving. In this context, TAAFFE (1975) remarks that "most social scientists today find themselves devoting an inordinate amount of time to soul-searching if not agonizing about the position of their own research on the continuum between theory building 
and problem solving. Transportation geographers feel this particularly keenly in part because of the prominent role of theoretical-quantitative work in the development of that subfield during the 1960's." But just as the two ends of the horseshoe turn in toward one another, so too with the relationship between theory and practice. One is ill-prepared to solve problems in the absence of theory, just as a physician cannot properly diagnose a patient without knowledge of medical theory. Likewise, theory is improved through understanding gained in applied problem solving. TAAFFE goes on to say that "a wide variety of transport problems could benefit from more attention from geographers, some clearly spatial, others less so. Whatever a transport geographer's position on the theory-practice continuum might be, current transport problems are of potential relevance to him, even though some of the more critical issues may seem far removed from geographical study. The view from the ivory tower should not seem myopically confined to those problems for which a welldeveloped body of theory exists." (TAAFFE 1975, pp. 276-277.)

Although there are many areas in urban transportation in which geographers may make meaningful contributions, four general areas are suggested here. In addition to a greater concern with applied spatial research and planning, as just described, geographers should focus greater attention on problems of transit location and flows on transit systems; the relationships between energy and transportation; and the flow or freight in urban areas. With increased, though still modest, funding of transit projects in the future, spatial analysis of where to locate the facilities, where the positive and negative impact will be felt, and what the usage pattern is on existing systems are all fundamental questions for which definitive answers are currently lacking (HoRTon et al. 1973). Since transportations uses about a quarter of all energy consumed in the United States as fuel for motive purposes, a large complex of interrelated research problems spring to mind, from improved spatial efficiency in the movement of people and commodities to interaction patterns resulting from different levels or kinds of energy alternatives. * Although geographers have studied the movement of people in cities to a considerable extent, there has been very little analysis of the flows of freight within cities. Many of the basic patterns of interaction remain unknown (GRIGGs 1972). Thus, by a complementary combination of research on theoretical and applied issues, urban transportation geographers will continue to expand their understanding of urban movement systems and be able to offer useful insights to the solution of urban transport problems.

* Recent papers on these issues by geographers include D. F. Marble: Energy Utilization and Alternative Patterns of Travel Behavior; W. Black: Energy and Other Tradeoffs in Rail and Truck Shipment and their Effect on Industrial Location, and F. E. Hortor and J. Hurquist: Long-Range Policy Considerations in an Energy-Risk Environment. Papers presented at the American Association for the Advancement of Science, January, 1975, New York. 


\section{REFERENCES}

Allen, W. B. and Boyce, D. E. (1974): Transportation Research: Problems and Prospects. Papers of the Regional Science Association, Vol. 32, pp. 21-51.

Anderson, J. (1971): Space-time Budgets and Activity Studies in Urban Geography and Planning. Environment and Planning, Vol. 3.

Appleyard, D. (1971): Social and Environmental Policies for Transportation in the 1970's. Institute for Urban and Regional Development, University of California, Berkeley, Working Paper No. 161, p. 1.

Austin, C. M. (1974): The Evaluation of Urban Public Facility Location: An Alternative to Benefit-Cost Analysis. Geographical Analysis, Vol. 6, pp. 135-145.

Barnes, C. F. Jr. (1967): Living Patterns and Attitude Surveys. Highway Research Record, No. 187, pp. 43-54.

Bernstein, S. J. (1973): Mass Transit and the Urban Ghetto. Traffic Quarterly, Vol. 27, pp. 431-449.

BerRy, B. J. L. (1959): Recent Studies Concerning the Role of Transportation in the Space Economy: Annals, Association of American Geographers, Vol. 49, pp. 328-342.

Berry, B. J. L. (1966): Research Frontiers in Urban Geography: In Ph. M. Hauser and L. F. Schoner (editors): The Study of Urbanization. New York: John Wiley, pp. 403-430; quotation, p. 403.

Berry B. J. L. and Horton, F. E. (1970): Geographic Perspectives on Urban Systems. PrenticeHall, Englewood Cliffs, New Jersey.

Black, W. R. (1971): Trip Distribution and Urban Spatial Behavior. East Lakes Geographer, Vol. 7 , pp. 13-21.

Bleiker, H. et. al. (1971): Community Interaction as an Integral Part of the Highway Decision-Making Process, Highway Research Record, No. 356, pp. 12-25.

Brown, L. A. and Moore, E. G. (1970): The Intra-Urban Migration Process: A Perspective. Geografiska Annaler, Series B, Vol. 52, pp. 1-13.

Burgess, E. W. (1925): The Growth of the City. In R. F. Park, et al. (editors): The City. Chicago: University of Chicago Press, pp. 47-62.

Chapin, F. S. Jr. (1968): Activity Systems and Urban Structure: A Working Scheme. Journal of the Institute of American Planners, Vol. 34, pp. 11-18.

Chapin, F. S. Jr. (1974): Human Activity Patterns in the City: Things People Do in Time and in Space. New York, John Wiley.

CraIK, K. H. (1969): Transportation and the Person. High Speed Ground Transportation Journal, Vol. 13, January, pp. 86-91.

Davies, C. S. (1972): The Reverse Commuter Transit Problem in Indianapolis. In H. M. Rose (editor): Geography of the Ghetto: Perceptions, Problems, and Alternatives. DeKalb, Illinois: Northern Illinois University Press, pp. 169-196.

Davies, C. S. and Arbaum, M. (1972): Mobility Problems of the Poor in Indianapolis. Antipode Monographs in Social Geography, Vol. 1, pp. 67-87.

Deskrns, D. R. Jr. (1972): Race, Residence, and Workplace in Detroit, 1880 to 1965. Economic Geography, Vol. 48, pp. 79-94.

Fiecoing, G. J. (1968): Locating Urban Freeways: A Method for Resolving Community Conflict. In F. E. Horton (editor): Geographic Studies of Urban Transportation and Network Analysis. Evanston, Illinois: Northwestern University, Studies in Geography No. 16, pp. $76-101$.

Fiflding, G. J. (1970): Transport Impact Research: Problems of Location Decisions at the Community Level. Annals of Regional Science, Vol. 4, pp. 117-126.

Garrison, W. L. (1959-1960): Spatial Structure of the Economy: I, II, and III. Annals, Association of American Geographers, Vols. 49 and 50, pp. 232-239, 471-482, and pp. $357-373$.

Garrison, W. L. and Marble, D. F. (1965): A Prolegomenon to the Forecasting of Transportation Development. Research Report, Transportation Center, Northwestern University.

Garrison, W. L. and Marts, M. E. (1958): Geographic Impact of Highway Improvement. Seattle: University of Washington Press.

Garrison, W. L. et al. (1959): Studies of Highway Deselopment and Geographic Change. University of Washington Press, Seattle.

Golant, S. M. (1972): The Residential Location and Spatial Behasior of the Elderly: A Canadian Example. Chicago: University of Chicago, Department of Geography Research Paper 143. 
Goldedge, G. et al. (1972): Behavioural Approaches in Geography: An Overview. The Australian Geographer, Vol. 12, pp. 59-79.

Greenwood, N. and Edwards, J. M. B. (1973): Transportation. In Human Environments and Natural Systems. North Scituate, Mass.: Duxbury Press.

Greytak, D. (1974): The Journey to Work: Racial Differentials and City Size. Traffic Quarterly, Vol. 28, pp. 241-256.

Grier, G. W. (1971): Social Impact Analysis of an Urban Freeway System. Highway Research Record, No. 305, pp. 63-74.

Griggs, N. J. (1972): Bibliography on Urban Commodity Transportation. Monticello, Illinois: Council of Planning Librarians.

HAGERSTRAND, T. (1967): Innovationsforloppet ur korologisk synpunkt. Lund: Gleerup, 1953; translated by Allan Pred; Innosation Diffusion as a Spatial Process. Chicago: University of Chicago Press.

Hanson, P. O. and Hanson, S. (1975): Travel Patterns and Cognitive Levels of Elderly Households in an Urban Environments. Papers presented at the Milwaukee meeting of the Association of American Geographers, April, 1975.

Hanson, S. and Marble, D. F. (1971): A Preliminary Typology of Urban Travel Linkages. East Lakes Geographer, Vol. 7, pp. 49-59.

Harris, Ch. D. and Ullman, E. L. (1945): The Nature of Cities. Annals of the American Academy of Political and Social Science, Vol. 142, pp. 7-17.

Herbert, D. (1973): Urban Geography: A Social Perspective. New York: Praeger Publishers, quotation p. 238.

Hetrick, V. R. and Calkins, H. W. (1972): Urban Mass Transportation in Seattle: A Behavioral Analysis of Special Election Results. Proceedings, Association of American Geographers, Vol. 4, pp. 41-45.

Higgs, G. (1975): An Assessment of the Action Component of Action Space. Geographical Analysis, Vol. 7, pp. 35-50.

Horton, F. E. (editor) (1968): Geographic Studies of Urban Transportation and Network Analysis. Evanston, Illinois: Northwestern University, Studies in Geography, No. 16, p. 111.

Horton, F. E. and Hulquist, J. (1971): Urban Household Travel Patterns: Definition and Relationship to Household Characteristics. East Lakes Geographer, Vol. 7, pp. 37-48.

Horton, F. E. and Reynolds, D. R. (1971): Effects of Urban Spatial Structure on Individual Behavior. Economic Geography, Vol. 47, pp. 36-48.

Horton, F. E., Louvière, J. and Reynolds, D. (1973): Mass Transit Utilization: Individual Response Data Inputs. Economic Geography, Vol. 49, pp. 122-133.

Horwood, E. M. (1965): Community Consequences of Highway Improvement. Highway Research Record. No. 96, pp. 1-2; quotation p. 2.

Ноут, H. (1939): The Structure and Grosth of Residential Neighborhoods in American Cities. Washington, D. C.: Government Printing Office.

Hurf, D. L. (1960): A Topographic Model of Consumer Space Preference. Papers of the Regional Science Association, Vol. 6, pp. 159-173.

Huff, D. L. (1963): A Probabilistic Analysis of Shopping Center Trade Areas. Land Economics, Vol. 34, pp. 81-90.

Huff, D. L. (1969): Ecological Characteristies of Consumer Behavior. Papers of the Regional Science Association, Vol. 7, pp. 19-28.

IIurst, M. E. E. (1974): Transportation Geography: Comments and Readings. New York: McGraw-Hill; see especially pp. 451-506.

Jefferson, M. (1928): The Civilizing Rails. Economic Geography, Vol. 4, pp. 217-231.

KAIN, J. F. (1963): Commuting and the Residential Decisions of Chicago and Detroit Business District Workers. Santa Monica, California, the RAND Corporation Bulletin P-2735.

KAIN, J. F. (1965): The Effect of the Ghetto on the Distribution and Level of Nonwhite Employment in Urban Areas. Santa Monica, California, the RAND Corporation Bulletin P-3059-1.

LASH, M. (1973): Environmental Requirements of the Federal-Aid Highway Program. Environmental Considerations in Planning, Design, and Construction, Special Report, 138, Highway Research Board, Washington, D. C., pp. 6-8; quotation p. 6.

Manherm, M. L. (1971): The Impacts of Highways on Environmental Values. Highsway Research Record, No. 305, pp. $26-27$.

MANHEIM M. L. and SUHRBIER, J. H. (1973): Incorporating Social and Environmental Factors in Highway Planning and Design. Ensironmental Considerations in Planning, Design, and 
Construction, Special Report, 138, Highway Research Board Washington, D. C., pp. 9-22; quotation p. 13.

Marble, D. F. (1967): A Theoretical Exploration of Individual Travel Behavior. In. W. L. Garrison and D. F. Marble (editors): Quantitative Geography Part I: Economic and Cultural Topics. Evanston, Illinois: Northwestern University Studies in Geography No. 13, pp. $33-53$.

Marble, D. F., and Bowlby, S. R. (1968): Shopping Alternatives and Recurrent Travel Patterns. In F. E. Horton (editor): Geographic Studies of Urban Transportation and Netsork Analysis. Evanston, Illinois: Northwestern University, Studies in Geography, No. 16, pp. $42-75$.

Marble, D. F. and Nystuen, J. D. (1942): An Approach to the Direct Measurement of Community Mean Information Fields. Papers and Proceedings of the Regional Science Association, Vol. 11, pp. 99-109.

Markovitz, J. K. (1971): Transportation Needs of the Elderly. Traffic Quarterly, Vol. 25, pp. $237-253$.

Mason, J. B. and Moore, Ch. Th. (1971): Development of Guides for Community Acceptance of Highway Location, Development and Construction. Highway Research Record, No. 356, pp. $43-54$.

MAYER, H. M. (1963): Urban Geography and Urban Transportation Planning. Traffic Quarterly, Vol. 17, pp. 610-631.

Mayer, H. M. (1969): Cities: Transportation and Internal Circulation. Journal of Geography, Vol. 68, pp. 390-405.

McConkey, D. D. (1973): Ecology's Impact on Transportation. High Speed Ground Transportation Journal, Vol. 7, January, pp. 17-24; quotation p. 17.

Morrill, R. and Pists, F. R. (1967): Marriage, Migration, and the Mean Information Field: A Study in Uniqueness and Generality. Annals, Association of American Geographers, Vol. 57, pp. 401-422.

Muller, P. O. (1971): Recent Developments in the Spatial Analysis of Transportation. Pennsylpania Geographer, Vol. 9, pp. 14-17.

Mulder, P. O. (in press): Social Transportation Geography. In Progress in Geography.

Mumphrey, A. J. and Wolpert, J. (1973): Equity Considerations and Concessions in the Siting of Public Facilities. Economic Geography, Vol. 49, pp. 109-121.

Murphy, R. E. (1966): The American City: An Urban Geography. New York: McGraw-Hill.

Netzer, D. (1970): Economics and Urban Problems. New York: Basic Books.

Notess, C. B. (1973): Trends in Urban Transportation. Transportation Engineering Journal, Vol. 99, pp. 655-674.

Nystuen, J. D. (1967): A Theory and Simulation of Intraurban Travel. In W. L. Garrison and D. F. Marble (editors): Quantitative Geography Part I: Economic and Cultural Topics. Evanston, Illinois: Northwestern University, Studies in Geography, No. 13, pp. $54-83$.

Orsson, G. (1965): Distance and Human Interaction. Philadelphia: Regional Science Research Institute.

Ornati, O. A. (1969): Transportation Needs of the Poor: A Case Study of Nesw York City. New York: Praeger Publishers.

Pendakur S. and Brown, G. R. (1969): Accessibility and Environmental Quality. Highway Research Record, No. 277, p. 40. Transportation and Community Values. Highway Research Board, Special Report No. 105, Washingto n, D. C.

Perle, E. D. (1968): Urban Mobility Needs of the Handicapped: An Exploration. In F. E. Horton (editor): Geographic Studies of Urban Transportation and Network Analysis. Evanston, Illinois: Northwestern University, Studies in Geography, No. 16, pp. 20-41.

Rabin, Y. (1973): Highways as Barriers to Equal Access. Annals of the Academy of Political and Social Science. Vol. 407, pp. 63-77.

Roтнman, R. (1973): Access Versus Environment. Traffic Quarterly, Vol. 27, January, pp. 111- 131 .

Sloss, G. J. (1971): Environmental Aspects of Transportation Planning. Council of Planning Librarians, Exchange Bibliography No. 218, Monticello, Illinois, 18 p.

Smerk, G. M. (1965): Urban Transportation: The Federal Role. Bloomington, Indiana: Indiana University Press.

Smerk, G. M. (1974): Urban Mass Transportation: A Dozen Years of Federal Policy. Bloomington, Indiana: Indiana University Press. 
TAAFFe, E. J. (1956): Air Transportation and United States Urban Distribution. Geographical Review, Vol. 46, pp. 219-239.

TAaffe, E. J. (1962): The Urban Hierarchy: An Air Passenger Definition. Economic Geography, Vol. 38, pp. 1-14.

TAAFFe, E. J. (1974): The Spatial View in Context. Annals, Association of American Geographers, Vol. 64, pp. 1-16.

TAAfFe, E. J. (1975): Current Transport Problems and the Geographer. Geographical Revies,, Vol. 65, pp. 274-277; quotation pp. 274-275.

TAAffe, E. J. et al. (1963): The Peripheral Journey to Work. Evanston, Illinois: Northwestern University Press, 1963.

Ullman, E. L. (1954): Transportation Geography. In P. James and C. Jones (editors): American Geography: Inventory and Prospect. Syracuse: Syracuse University Press, pp. 310-332.

WaCHS, M. (1971): Basic Approaches to the Measurement of Community Values. Highway Research Record, No. 305, pp. 88-98.

Walton, L. E. Jr. and Saroff, J. R. (1971): Proposed Strategy for Public Hearings. Highway Research Record, No. 356, pp. 26-31.

Ward, J. D. and Paulhus, N. G. Jr. (1974): Suburbanization and Its Implications for Urban Transportation Systems. Washington, D. C.: U.S. Department of Transportation, A pril.

Webber, M. M. (1971): Alternative Styles for Citizen Participation in Transport Planning. Highway Research Record, No. 356, pp. 6-11; quotation p. 6.

WeINer, P. and Deak, E. J. (1971): Nonuser Effects in Highway Planning. Highway Research Kecord, No. 356, pp. 55-68.

WeINER, P. and DEAK, E. J. (1972): Environmental Factors in Transportation Planning. Lexington Books, Lexington, Massachusetts.

WheELer, J. O. (1968): Work-Trip Length and the Ghetto. Land Economics, Vol. 44, pp. $107-112$.

Wheeler, J. O. (1969): Transportation Problems in Negro Ghettos. Sociology and Social Research, Vol. 53, pp. 171-179.

Wheeler, J. O. (1971a): An Overview of Research in Transportation Geography. East Lakes Geographer, Vol. 7, pp. 3-12.

Wheeler, J. O. (1971b): The Spatial Interaction of Blacks in Metropolitan Areas. Southeastern Geographer, Vol. 11, pp. 101-112.

Wheeler, J. O. (1972a): Trip Purposes and Urban Activity Linkages. Annals, Association of American Geographers, Vol. 62, pp. 641-654.

Wheeler, J. O. (1972b): Spatial Studies in Transportation: Introduction and Annotated Bibliography. Council of Planning Librarians, Exchange Bibliography Nos 324-325, Monticello, Illinois, $161 \mathrm{p}$.

Wheeler, J. O. (1973): Intrdouction: Societal and Policy Perspectives in Transportation Geography. Economic Geography, Vol. 49, pp. 11 and 181-184.

Wheeler, J. O. (1974): The Urban Circulation Noose. North Scituate, Mass.: Duxbury Press.

Wiseman, R. (1975): Racial Variations in Urban Elderly Travel Behavior. Paper presented at the Milwaukee meeting of the Association of American Geographers, April.

Witheford, D. K. (1973): Engineers, Urban Freeways, and the Public. Traffic Quarterly, Vol. 27, Januarv, pp. 145-158; quotation p. 145.

Wolpert, J. (1965): Behavioral Aspects of the Decision to Migrate. Papers of the Regional Science Association, Vol. 15, pp. 159-169.

Wolpert, J., Mumphrex, A. and Seley, J. (1972): Metropolitan Neighborhoods: Participation and Conflict over Change. Washington, D. C.: Association of American Geographers, Commission on College Geography, Resource Paper No. 16.

Yeates, M. H. and Garner, B. J. (1971): The North American City, New York: Harper and Row. 


\section{CENTRAL BUSINESS DISTRICT OR SHOPPING CENTER - AN AMERICAN DILEMMA}

By

GEORGE KISH

In an article published in 1937. Malcolm Proudfoot, American geographer, summarized the principal types of urban retail structure as follows:
a. Central Business District
b. outlying business center
c. principal business thoroughfare
d. neighborhood business district
e. isolated store cluster.

The progress of urbanization in North America, urged on by the twin phenomena of the growth of transportation by automobile and the parallel increase of urbanized areas outside the central city, brought about major changes in life in general and in retail merchandizing in particular. Thus, BRIAN BERRY, American geographer writing in 1963, could offer a new classification of urban retail structures (see Fig. I) taking into account the changes that had taken place during the post-World War II era. BERRY distinguishes three classes of commercial development: centers, street- or highway-oriented ribbon developments, and specialized areas. In this discussion, attention is drawn to the first of these classes, with special emphasis on the discrete growth, possibly the different evolution, of two categories within it, the Central Business District and the business centers, by they neighborhood-oriented, community-oriented, or regional-oriented in their design.

The two forces that have been responsible for the gradual decline of Central Business Districts on the one hand, the emergence of Shopping Centers on the other have been the evolution of the American transportation systems, and the sharp increase of urban growth in suburban areas.

The total number or registered motor vehicles (automobiles, taxicabs, trucks and buses) in the United States increased from 31,035,000 in 1945 to $125,157,000$ in 1973 , an increase of 400 per cent in twenty-eight years. Responding to this phenomenal increase, especially noticeable in the even greater percentual growth of privately owned motor vehicles, there has taken place an expansion of the highway network, with special emphasis both on the construction of interurban, multi-lane, limited access motorways, and on the parallel construction of inter-city motorways with the same characteristics. Americans have become so dependent on the individually owned automobile that public transportation systems have been losing ground in virtually all urban and suburban districts. The concomitant growth of such problems as traffic congestion both on existing streets and, during peak hours, on the 


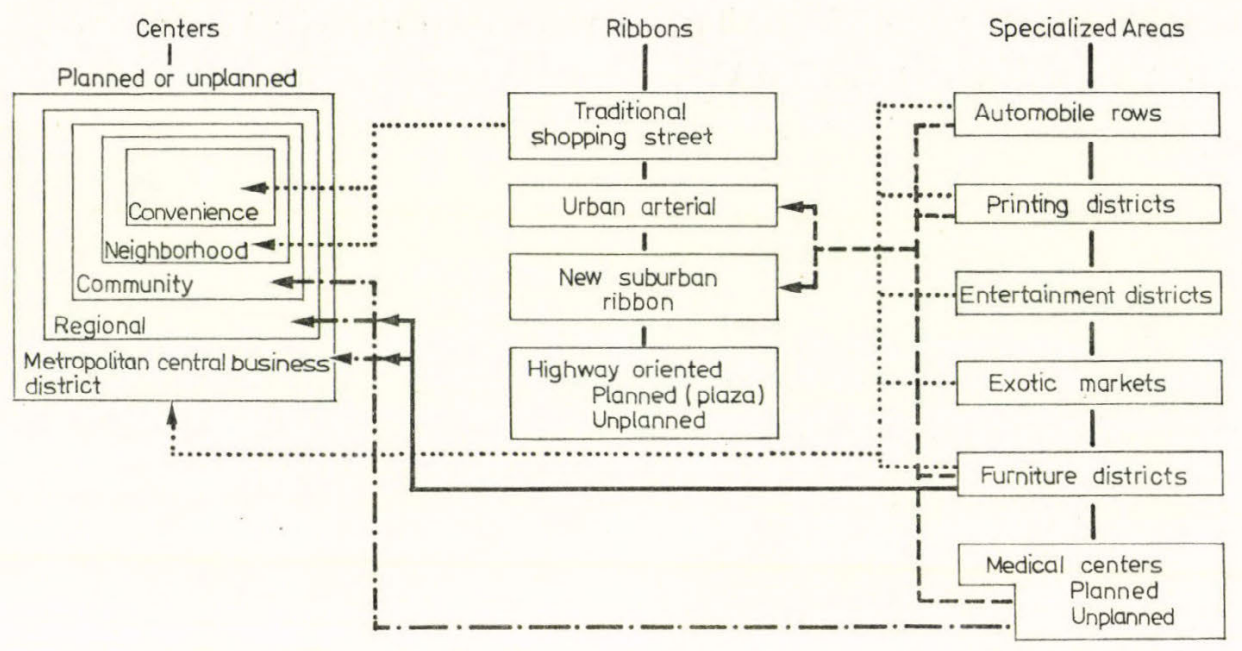

Fig. 1. BerRy's concept of the structure of business and commerce in the city (after Table II. in Brian, J. L. Berry: Commercial Structure and Commercial Blight. Department of Geography, Research Paper, No. 85, University of Chicago, Chicago, 1963).

motorways; the pressing need for parking areas that occupy an increasing percentage of cities and towns; and the exponentially increasing consumption of fuels, atmospheric pollution, and traffic casualties occupies a substantial portion of the time, energy and imagination of all public officials.

Equally responsible for the change in American ways of doing many things, including retail shopping, has been the building boom that in the twenty-five or so years following the Second World War multiplied the number of dwellings, expanded - with heavy public subsidy - urbanized areas outside the central city, and in a qualitative sense introduced a clear-cut separation between areas of work and areas of residence.

The twin forces of "motorized" and "suburbanized" living bear the responsibility of this dilemma: Central Business District or Shopping Center, that affects most facets of urban living in America at present.

The concern of this presentation lies with the "controlled shopping center", that is, a conglomerate of stores and services established by private interests, following a loosely structured plan in most instances, as distinguished from the Central Business District whose origins go back to the early growth of cities, and whose development followed less structured line, responding in the main to the habits and demands of the public in an era of predominantly public transportation systems.

The shopping center, in the main, has several well-defined attractions to the public. Foremost among these is the availability of parking space, perhaps the most curious of all advantages, for the public fails perceive that the distance between the parked vehicle and the store or stores patronized is often equal to, and sometimes distinctly greater than, the distance between the parking lot or parking structure in the Central Business District and the stores 
patronized there. Yet the fact of free parking on the one hand, and the illusion of proximity created by the ability to see the parking place where one's car was left outweighs all other considerations.

A second significant advantage is the "neighborhood" character of even the largest of the shopping centers, carrying with it the connotation of informality in dress, in general appearance, and - an important consideration since many of the shoppers are women accompanied by their children - the opportunity to take the children along, being freed thus of the necessity to provide child care during shopping hours, and the far from negligible attraction of a diversion for the youngsters.

A third point in favor of the shopping centers is the wide variety of stores and services located there, often distinctly greater than in the older "downtown" business district. At the same time, an increasing number of the stores and services in the shopping centers are open during a much greater portion of the day than the traditional, downtown establishments, most of which close at 5:30 in the afternoon, while the shopping centers' hours extend well into the evening, at least until 8 o'clock, and some stores are now open on Sundays as well. This offers a greater number of choices to the customer, and is a very significant added convenience.

Last but not least is the matter of accessibility of the shopping centers. Located near major urban or suburban motorways, easily accessible from arterial city and suburban streets, the shopping center appears to the custome as a place so much easier to reach than the central business district. And while perception may play a role here, too, making the easily traversed and generally less congested arterial roads and motorways more attractive than the older, narrower thoroughfares of the central city, one must keep in mind that the wide spread of suburban areas tends to centralize the shoppers' attention on the "nearby" shopping center that, in many cases, is closer in miles traversed than the traditional "downtown".

The first of the major "controlled shopping centers" were built around a single core: the branch store of a major, long-established department store, located within the Central Business District. NORTHLAND, the first of these centers in the Detroit metropolitan area, was indeed structured around a branch of Hudson's, Detroit's leading department store, located in the very heart of the "downtown" area. Surrounding it there came into existence other smaller retail stores of great variety, including restaurants and retail food outlets.

The layout of these shopping centers includes a central structure, housing the branch of the department store responsible for the project or, at the least, having provided the original idea; a set of open walkways, sheltered only by a roof or overhang, connects the central structure with others housing stores and restaurants. Some slight effort was often made to provide an artistic touch, through the addition of fountains, pools, and in some instances small, attractive playgrounds.

The second form of shopping center, following the first after an interval of from eight to ten years, developed in part as a response to climatic conditions, i.e. protection from high summer temperatures or from very cold winter temperatures, in part as a response to the perceived preferences of the public, 
preferring to stroll within a completely enclosed, air-conditioned building. The Montgomery Mall in suburban Washington, D. C., the Somerset Mall in suburban Detroit, and several smaller "malls" developed by a single corporation in the Midwest, of which the Briarwood Mall in Ann Arbor, Michigan, is a sample, belong to this group.

In the "single mall", one-structure, all-enclosed shopping centers a group of department or chain stores, rather than a single major department stores, provides the dominant note. As a rule, they include shops appealing to a clientele of a higher income group than the earlier centers; there one finds an increasing number of "specialty shops" (imported foods, tobacco stores, book stores and the like); there is a greater variety of restaurants and of such services as banking and post offices. In order to attract - and to keep - their clientele, these "malls" offer both formalized entertainment, in one or more movie theaters, and informal entertainment, by community musical and theatrical groups, in the central, usually spacious and well-designed core that, most of the day, serves as a meeting and resting place for shoppers.

The Central Business District, together with the core of the old central city, has been showing clearly visible effects of the rise of the shopping centers. Some are apparent to the most casual observer, even if unacquainted with the apperance of the district two or three decades ago: empty or even boarded up store fronts, abandoned buildings, the replacing of specialty shops by others catering to a lower income clientele, and offering generally lower quality merchandise. In some extreme instances the very organizations responsible for the rapid growth of the shopping centers are suffering from the consequences of their action, thus Hudson's department store in downton Detroit, long a leading institution of the city's retail trade, is now offering several of its floors on a rental basis for outside business concerns, as a result of the sharp decline of the store's sales volume.

Urban blight, in many forms, now seems part of the life of the inner city and creates problems not only for the Central Business District but for the municipality as a whole. Some of the consequences of the "flight from downtown" are social, including the changing character of the population of the central city, showing a marked increase, absolute as well as proportional, of minority groups in the population. Other consequences are fiscal: the sharp decrease of the city's tax base, due in part to lower valuation of central city properties as part of the response of business to falling sales and lower incomes, in part as a response to the withdrawal from the tax base of areas transformed into parking lots, new arterial roads and motorways. The increasing inability of the central city to maintain the quality of urban services: schools, police and fire protection, sanitation, shows clearly the slow agony of the inner city.

What response have American cities offered to the sharp challenge of the shopping center? There are instances where a combination of imaginative planning, well-organized municipal support, and a positive reaction of the business interests resulted in a clear-cut upswing, a revitalization of the old Central Business District: the Loop and North Michigan Avenue areas of downtown Chicago, and the district surrounding St. Francis Square in central San Francisco are outstanding and encouraging examples. 
Some communities responded by creating pedestrian malls, areas where all vehicular traffic is exluded, providing easy access to stores and a pleasant atmosphere, enhanced by special lighting fixtures, benches, flower arrangements, and imaginatively designed storefronts and display windows. Kalamazoo, Michigan, pioneered in this respect, so did, on a larger scale, Miami Beach.

Yet another response was the building of "shopping malls" in the city center. This was done partly through the use of urban renewal techniques, replacing decaying structures with new ones, partly by using a multi-story approach, above and below ground sets of stores, offering controlled temperatures summer and winter, as well as convenient parking, whenever possible, in adjacent parking structures. Montreal has its "Ville Marie", London, Ontario its downtown shopping malls. Saginaw, Michigan combined three structures: shopping mall, civic center offering library, theater, and music auditorium facilities, and parking building, all connected with covered walkways.

Cities across America are responding in a variety ways to what, belatedly, they recognize as a potentially lethal threat to their survival as viable social organisms. Whether the measures offered so far can be effective remains to be seen.

In several respects, the innovative characteristics of the shopping centers have so far outstripped even the best designed urban solutions. One is tempted to place at the top of the list the willingness of stores in the shopping centers to keep long hours and, in some instances, to open on Sundays, while the downtown malls continue to keep conservative, much shorter hours. Another is the unwillingness of the public to face the real or imagined inconvenience of downtown parking, with its added - and sometimes considerable - expense, opposed to the shopping centers' free parking policy. Yet another, rather real advantage of the shopping centers is the absence of clear-cut rush hour traffic congestion, ever-present in downtown areas where other urban activities continue even though retail trade is suffering a decline.

No one can forecast what the impact of possible restrictions on unlimited use of fuel private driving may be. Nor does anyone know what are the chances of reviving public urban transport, now being revived from its nearly defunct state in most American urban centers. At best, it is possible to foresee an increase in the spirit of competition between the Central Business District and the shopping center, bringing into much sharper focus this American dilemma. 

Part three

NATURAL ENVIRONMENT OF THE CITIES 



\section{LONG-TERM DEVELOPMENT OF THE BUDAPEST AGGLOMERATION - AN EVALUATION OF THE PIIYSICAL-GEOGRAPHICAL POTENTIALS}

By

MÁRTON PÉCSI and SÁNDOR KATONA

The main principle of the long-term development projects (up to 2000) of the Budapest agglomeration (including 22 districts of the capital and the surrounding belt of 44 settlements) is that though the present economic predominance of the capital over the country as a whole is decreasing, overall economic growth here will still remain the most significant.

The growth of population and the concentration of housing and infrastructural establishments persists with the growth of industrial production and even more with the rapid increase of services. The socio-economic pressure exerted on the environment is intensified, and as a result the transformation and deterioration of the environment is also expected to grow. Though environmental damage is not as grave as it is in many American cities, in an agglomeration with more than two million people, it emerges more and more markedly, which urges us to take preventive measures for the protection of the environment.

In city and settlement development projects therefore, greater emphasis could be laid upon the ecological approach.

In the past years working group of the Research Institute of Geography of the Hungarian Academy of Sciences, took part in planning the longterm development of the Budapest agglomeration, and as part of their work, they evaluated the natural environmental potentials of the Capital and its surroundings.

From the materials of his natural environment man has created a man-made environment, the city. With the flocking of population into the towns, and with the rapid formation of agglomerations, this process has been reversed; nowadays settlements spread over their natural environment in confusion, destroying partly or wholly the original biocoenoses. The man-made landscape of the city has come into being as the negation of the natural landscape by destroying the latter, and by upsetting the environmental balance.

The interrelation between man and his environment has undergone changes with the development of society. Spontaneous exploitation before mass industrial production modified the environment, but did not cause harmful deterioration, has the balance of the natural eco-systems survived. In industrial societies the excessively ruthless exploitation of the environment has often led to irreversible damage which seriously endangers the health of the inhabitants and compels us to make a conscious effort to protect the environment and effectively plan land utilization. From the research workers, this requires an urgent analysis and evaluation of the environment with an ecological approach in mind. 
We have approached the urban formations of the Budapest agglomeration as one that is in close interaction with its geographical environment, which alters the energy balance, pollutes the atmosphere and hydrosphere, degrades the biosphere, dispossess materials of the lithosphere and loads it with solid waste. In other words, it upsets the equilibrium of the natural environment.

\section{NATURAL LANDSCAPE TYPES OF BUDAPEST AND ITS SURROUNDINGS}

Budapest with its widespread agglomeration lies at the boundary of two landscape types with different natural and economic potentials, namely, the Great Hungarian Plain and the Hungarian Mountains. Among the attracting forces both the local (the Danube, thermal springs, building stone) as well as regional factors (central position within the basin, fords attracting roads and the conjunction of regions of different production), have long played an important part.

The Danube with its wide flood plains, is to some extent, a natural boundary between the hill type and lowland type landscapes, not only separates but as a waterway, also links them together.

The older and today smaller part of the capital is Buda, west of the Danube. It spreads over the formerly forested hills and slopes of the Buda mountains. The larger part, east of the river is called Pest, spreading concentrically, radially and without restriction of topography (Figs 1 and 2).

\subsection{THE PEST PLAIN}

East of the Danube on the low lying flood plains and terraced surface settled the residential and industrial sector of Pest. In its initial stage the Pest plain was a sand-covered continental forest-steppe area. A zonal gallery forest and swamp forest covered both the higher and lower flood plains in a widening and narrowing belt. In fact along today's Great Ring Road (Nagykörút) ran an important branch of the Danube, which surrounded the island-like flood-free lower terrace of the present downtown area (Belváros). The Pest plain was dissected by valleys of boggy peaty meadow soils along the tributaries of the Danube, and these areas were periodically covered by floodwater just like the flood plain of the Danube. These latter landscape-ecological types were not favourable for settlement, and at the same time they controlled the direction and placement of transport routes.

The greater part of the higher flood plains of the Danube saw the growth of settlement in spite of the periodic flooding of the river against which protection needed from earliest times. The majority of the inner residential quarters of Pest, within the bounds of the Great Ring Road (Nagykörút) were built on this level, and after the catastrophic floods of the last century (1838) this district had to be embanked to the level of the flood-free terrace.

The lower and higher terrace of Pest Plain were, in their initial stage a mosaic of forest- and sandy areas. With their chernozem and brown forest soil they attracted quite early the garden and agrarian settlements in the outskirts. 


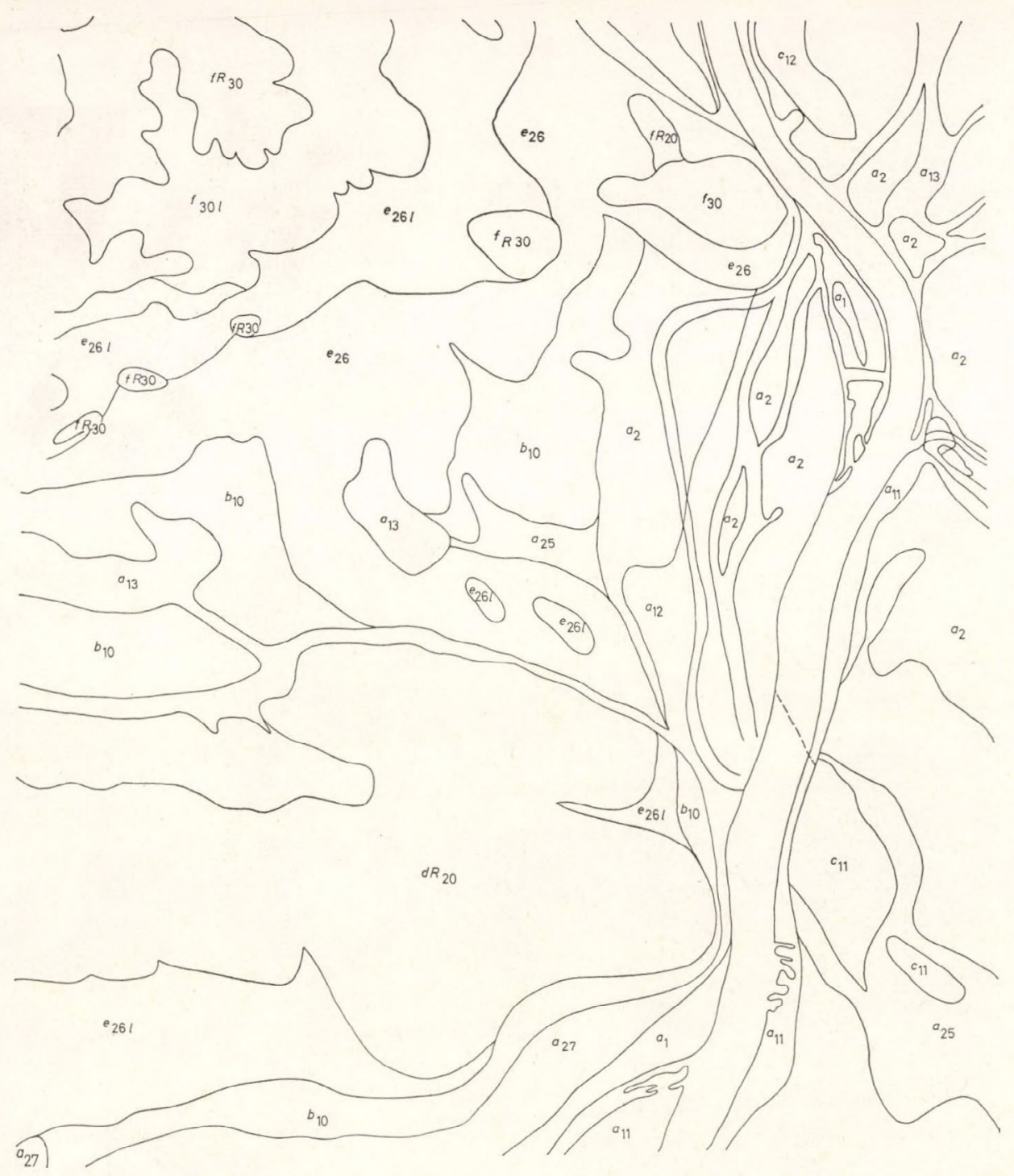

Fig. 1. Natural landscape ecological types of Budapest and its surroundings (compiled by M. Pécsi)

$a_{1}$ azonal low flood plains with gallery and swamp forest remnants; $a_{11}$ alluvial soils, natural levees with gallery forest remnants; $a_{12}$ low flood plain type of meadow soil; $a_{13}$ low flood plain type of boggy peaty meadow soil $a_{2}$ high flood plain of former forest-steppes with gallery forest type; $a_{25}$ high flood plain type of meadow soil with patches of sandy dunes; $a_{27}$ high flood plain type of meadow-chernozem

Loess plain type of forest-steppe: $b_{10}$ type of chernozem-forest loess plains

Former wooded mosaic-like sandy areas on alluvial fans: $c_{11}$ dunes with forest and sandy steppe meadow remnants; $c_{12}$ sand sheeted terrace type of steppe lowland with chernozem soils

Erosional - derasional hilly regions and foothill surfaces with subcontinental Turkey oak forest remnants: $d_{20}$ hilly regions covered with loess and slope sediments with brown forest soil type; $d R_{28}$ terraces and limestone plateaus covered by rendzina soil

Hilly regions in intermontane basins with subcontinental Turkey oak forest remnants: $e_{28}$ hilly regions with loess, brown forest soil type; $e_{201}$ hilly region loess on steep slopes, brown forest soil type

Predominantly forested upland landscape types with Turkey oak, hornbeam and oakwoods: $f_{301}$ type of upland low mountains of carbonate rocks covered by brown forest soil; $f R$, plateaus with rendzina soils on moderate uplands of carbonate rocks, and bare rocks; $f_{301}$ slopes steeper than $17^{\circ}$ of low uplands covered with brown forest soil 


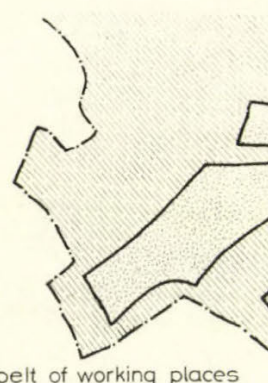

I. Inner (tertiary) belt of working places

Center of the city, area of central

institutions

111.Center of trade and services

1.12. District of administration and management(Parliament, Ministrie)

113 Center of education(central

buildings of universities)

114. District of cultural and touristical

interest (Castle)

I. Planned centers of districts in

order to decentralize the city core

1.3. Area of public institutions

(hospitals, schools, services)

I.4. Area of public institutions

surrounded by lawns

I Beit of residential districts

I1. Packed urban building-up(building of several storeys, closely located)

II.2. Loose urban building-up(building of several storeys, surrounded by lawns)

I. 3. Building-up with family houses

(garden, fruit trees)
II. Cuter (secondary) belt of working places

III.1.Area of industry and stores

III 2 Area of public services (gas,

water production, canalization)

II.3.Area of railway and highway transportation

III. 31. Railways

III 32 Trunk roads

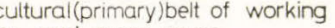

places and green areas

$\mathbb{\nabla}$. Agricultural cultivation

(parks, gardens, cemeteries)

IV.3.Forest

IV4Recreation areas

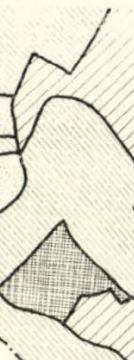

WIII
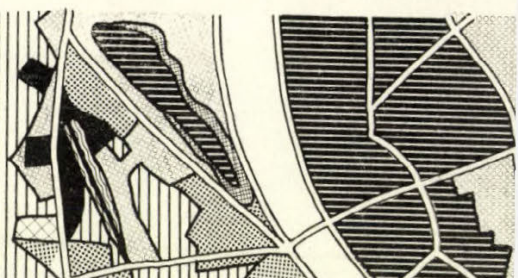
101
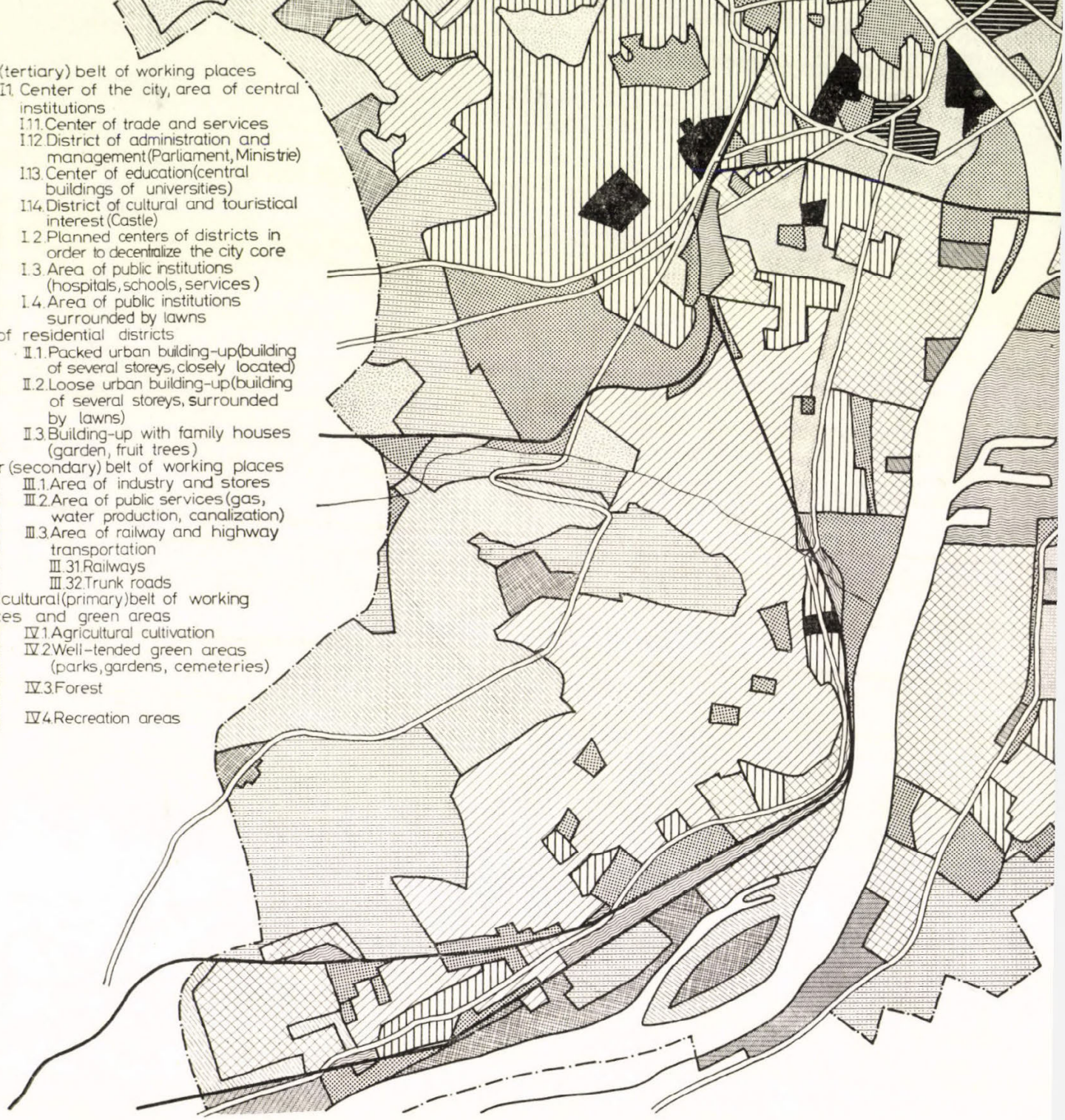
The gravels and sands of the alluvial fan terraces of the Danube, and also the Pannonian clays and Upper-Miocene coarse limestone lying below these formations, provided inexhaustible raw materials for building, at the beginning of the development of the town and its wider agglomeration.

\subsection{THE BUDA MOUNTAINS}

Across the lowland of Pest on the right bank of the Danube, on the former "Óbuda-Acquincum lowland" and on the plains of "Lágymányos and Budafok" south of the Gellert hill, lay a significant portion of the lower and upper flood plain of the Danube. The tributaries coming from the Buda Mountains built an alluvial fan (at Óbuda and Lágymányos) on the higher flood plain and these sites - being less endangered by flooding - were already inhabited in Roman times.

The "Castle Hill" (Várhegy) terrace of the Danube, because of its favourable strategic position - being a well demarcated terrace outlier - together with Gellért hill, quite early attracted the attention of settlers.

Favourable conditions for settlement were provided by the climatically sheltered, entrenched basins of the Buda mountains, which were originally covered by Turkey Oak-Oakwood-land on the brown forest soils formed on loess. The small basins in between the horsts furnished an excellent habitat for the early agrarian economies.

The horsts of the Buda mountain form only a moderate upland, which is made up mainly of carbonate rocks. The $4-500 \mathrm{~m}$ high summit level of the Buda mountains were dominated by Turkey Oak - Oak covered flat plateaus, which alternated with patches of scrub forests formed on shallow rendzina soils, or with bare rocks. In the horst type Buda mountains beside the summit levels large area are taken up by steep slopes of dolomite and limestone. These are adjoined by the gentle slopes of the loose sediments (loess and clay) of the foothill areas tending towards the interior of the basins or the terraces of the Danube. These areas in their original state were also subcontinental Turkey Oak and Oak, brown forest soil landscape ecological types.

They were the first to be turned into suitable areas of agrarian and garden forest cultivation, and later gave way to suburban settlements (cottage type) and weekend houses.

\section{PRINCIPLES OF THE ANTHROPOCENTRIC EVALUATION OF NATURAL POTENTIAL IN THE BUDAPEST AGGLOMERATION}

The crisis of the city: as the fast growing populations of cities have more and more free time, recreational areas shrink in size. Man is increasingly forced to live in a man-made yet alien surroundings.

Fig. 2. Long-term usage of south-west Budapest (compiled by S. Katona) 
The realization of the ecological approach in town-planning, in our opinion, should aim at the optimal anthropocentric utilization of the physical geographical environment and not at its maximum exploitation. The deliberate planning of the environment and its modification in man's own interest should mean the preservation and conservation of the components and valuable elements within the natural environment, by a rational and limited exploitation.

We have outlined the methods and objects of town planning in the Budapest agglomeration in terms of future demands, laying stress upon the following:

1. The availability of drinking water and industrial water is the alpha and omega of the existence of a metropolis with two million inhabitants. Its preservation and maintenance should take precedence over all other utilizations of the land.

2. The natural and man-made green areas (forests, parklands, parks and groves) providing relaxational and recreational possibilities, and also the intensively cultivated land use areas (gardens, vineyards, orchards) are more important - with the exception of water - than any other utilization of the land, as these are presently scarce, and in the long run they will have to satisfy a growing demand.

3. The allocation of new sites for industrial establishments and residential areas, considered as one of the basic functions of the city, should be done only after the above two types of land use have been satisfied, and with the needs of environmental protection kept well in mind.

4. The quarrying of building-materials, which leads to the destruction of the landscape, should only be permitted in exceptional cases around the city.

5. Being a not very typical function of the capital, the decrease of extensively cultivated agrarian areas (arable land, pastures and marshes) is to be expected. For a long time now the agglomeration of Budapest, has not been selfsufficient in agricultural products and satisfies its needs on the national consumer market.

\subsection{AN EVALUATION OF LITHOLOGICAL AND TOPOGRAPHICAL}

\section{POTENTIALS}

Litosphere and topography are the substrata of town building; they provide both the site for building as well as building materials. As a result of the research carried out by geomorphologists, our thematic map series on the scale of $1: 10,000$ shows the conditions for the founding of buildings in the built-up and the so far untouched areas of the capital and the tendencies in the change of relief and topography. They also provide answers to practical problems arising during the construction of buildings. Anthropogenic construction of the city is the counterpart of anthropogenic destruction of the landscape. Usually it is the quarrying of sand, clay, gravel and stone which is the most effective disturbing and destructive element of the topography.

Abandoned open-cast mines are open wounds, - which attract household garbage and industrial waste, and thus turn these surroundings into sources 
of infection. In the area of the Budapest agglomeration we have counted six hundred and fifty such pits awaiting recultivation, and we have submitted a proposal as to their landscape restoration.

\subsubsection{Evaluation of the lithosphere and topography from the point of view of the siting of buildings}

The concept and possibility of building-up an area is a relative one, as at all times it depends on the economic and technical stage of development of a given society. Man wanting to build has for a long time avoided the lowlying areas with inland water (Lágymányos), with persistent ground water (Budaörs basin), with steep slopes, or those liable to sliding (the slope of the terrace at Kiscell) and the peaty (part of Angyalföld) and marshy areas (the valley of the tributeries Szilas and Rákos). Today, in the age of intensive and mass construction of buildings - when the subsoil is overstrained because of the manifold increase in the weight of buildings - , the areas still available for building are those that were unfavourable from the very first. This is made worse by the presence of quarries filled with water, around Budapest (Kőbánya, Gubacs), or areas that have been undermined (Kőbánya, Budafok).

In the course of planning we have suggested the prohibition of building in all those areas that are to be preserved for the acquisition of water, or for the development and preservation of green areas, a belt roughly running along the Danube, and the forest covered areas of the Buda mountains. Problem areas building are:

a) slopes steeper than $17^{\circ}$ which, due to their relief potential, would be very expensive to build on;

b) areas liable to sliding due to their lithological components: slopes made up of Kiscell clay, or Buda marl, areas covered with loess or loess-like sediments occupying nearly half the area of the agglomeration, which, when overburdened may collapse, flat areas inundated by inland waters in rainy years, and peaty valley bottoms with loose sub-soils;

c) as a result of anthropogenic activities, the disturbed and unstable surfaces, abandoned quarries awaiting recultivation, the undermined areas, and those slopes dangerously disturbed by mining.

\subsubsection{Lithosphere as a source of building-stone}

Budapest and its surroundings are poor in exploitable mineral resources. In the development of the city, however, the great wealth of building-stone was an incentive at all times. One of the important bases for the monumental buildings of the capital was the local wealth of building materials.

The possibilities for quarrying building materials today are still favourable. In the evaluation of the potentials of the lithosphere, the economic factors should seriously be taken into account. When allocating a place for new building materials quarry, there are alternative possibilities. 
A) The further development of building-materials quarrying in the metropolitan area is justifiable because of the

a) growing demand for building materials in the Capital that generally parallels the development of the national economy;

b) Budapest is not solely a great comsumer, but at the same time it offers various natural potentials for quarrying of building materials;

c) bulky and relatively low-value building materials are most profitably quarried in areas as close as possible.

B) Arguments for closing building-materials quarries:

a) the city spreading vigorously because of intensive utilization of land forces the stone-quarries, clay-pits and sand-pits move away from the nearest locations;

b) the open quarries of building materials occupy extensive surfaces and are first class destructive forces in the landscape; the building material industry is an effective source of air pollution;

c) as a result of quarrying the disturbed topographical balance (Óbuda) extensive pits (Csepel) and undermined areas (Kỏbánya, Tétény) are problematic to build-on, and their restoration is an urgent task;

b) the abandoned quarries turn into garbage-dumps sooner or later.

\subsection{AN EVALUATION OF THE POTENTIALS}

\section{OF THE HYDROSPHERE}

The potentials of water supply in the metropolitan area lying beside the Danube are first class. The Danube and the ground waters of the flood plain in close contact with the river, will in the future, provide the necessary supply of industrial and drinking water. The hygienic quality of the water of the river coming from outside the national boundary, is objectionable even now, which makes the utilization of the area north of Budapest for sporting and recreational purposes highly questionable. South of the Capital the natural purification of the river only takes place after about $25-30 \mathrm{kms}$ because of the great amount of sewage drained into the Danube, which makes it impossible to use these waters for any purpose without expensive pretreatment. The fact that the tributaries flowing within the boundaries of Budapest have been degraded to mere sewers, is a further indication of the unaccomplished task of water purification.

Budapest is divided by a faulted tectonic line along the Danube where mineral and thermal springs gush forth with a great discharge of water; the settlement was rightly called a city of spas even in the Roman age. In the foothill areas of the Transdanubian Mountains the brown coal mines and the planned opening of bauxite mines, both below the karst water-level, endanger and could substantially ruin the potential value of these springs, before marking out areas for their protection, the deep water connections should be sufficiently explored and satisfactorily cleared up. For the Budapest agglome- 
ation as a whole, the preservation of areas suitable for the acquisition of water, and the maintenance of its good quality for industrial and drinking purposes, is a question of vital importance.

Ninety-eight percent of present-day needs, and those planned until 1980 are supplied by surface removal of water from the Danube, or indirectly from filtration-wells on the banks. There is no reason to worry about the quantity of water needed. In connection with the deterioration of the quality of water in the Danube, however, serious problems and expenses may arise, due to the increase in contamination, especially in the reaches below the Capital.

The potentials of the hydrosphere, taking into account environmental protection as well, can be summarized as follows:

1. The reaches of the Danube north of Budapest (the Island of Szentendre and its banks) should be primarily preserved for the acquisition of water. In the interest of maintaining purity, the use of chemicals in agriculture and the excessive application of fertilizers and insecticides should be restricted: industrial water consumption and drainage should be kept to the branch at Vác and the holiday resorts should be centered around the Szentendre branch as far as possible.

2. For the protection and preservation of the holiday resorts on the reaches of the Danube to the south of Budapest, the drainage of sewage-waters into Ráckeve branch, which has limited clarification chances, should be stopped; the sewage-waters on the Pest bank ought to be conducted across Csepel Island into the main branch of the Danube.

3. The fate of the tributaries within the bounds of the agglomeration, used today as sewers, is a special issue. These ought to be restored into natural waters as soon as possible, so as to relieve the Danube from additional sewage. For the further development of the bisophere (grean areas) the valley bottoms and flats having an abundant water supply by nature, are the most suitable in our moderately continental climate. The natural plant cover together with the streams protect and sustain each other; at the same time they provide pleasant surroundings for human relaxation.

\subsection{CLIMATIC POTENTIAL}

With the creation of extensive man-made surfaces, man has changed the energy and heat balance of the area. Man-made surfaces (asphalt, concrete, stone tile roofs) have increased disproportionately at the expense of areas covered with biologically active natural vegetation (forest, fields and meadows). The building-up of the city and the creation of a man-made landscape have led to the radical alteration of the natural macroclimate, and resulted in the birth of an urban mezo-climate, which in turn affects the nearby surroundings of Budapest. The basis of the city climate is the alteration of the energy balance (extra heat) and also the modification of the climatic elements (warm, dry).

The modified "town-surface" is a heat storer, while the "town functions" such as industrial production, transport vehicles, heating facilities and human masses are all producers of heat. The closely built-up inner districts have 
a typical urban mezo-climate in Budapest where the annual mean temperature is $0.8^{\circ}$ more and the January mean at least $1.2^{\circ} \mathrm{C}$ more than that in natural surroundings. The surplus in the center of the town is much more significant. This rise in temperature has a favourable moderating effect in winter, but in summer it adds to the already over-heated "stone-desert" of the city; the badly aerated streets with their dense air are stuffy indeed. The heat emitting city not only develops its own special mezo-climate, but it also modifies the micro-climate of the immediate vicinity. The propagation of plant thermophilous species in the forests of Buda mountains may be directly atributed to the negative effect of the city climate.

The polluted air is the most prominent feature of the city mezo-climate. A broad transitional zone has formed between the inner core of the city with its typical city-climate and the outlying suburbs which still have a natural density (with numerous emission sources) and the rate of diffusion. This greatly or less polluted transitional zone of variable width is the polluted natural climate of the intervening area. This mezo-climatic sub-type spreads over nearly half the area of Budapest, from the central core towards the outlying suburbs. According to city climatological research this air-pocket burdened by atmospheric pollution is fifty times greater than the built-up areas. Its height over the Capital may be as much as $2.5-3 \mathrm{kms}$. When the air is in motion this local pollution may extend over the region in the direction of the prevailing wind. Its effect can be felt $20 \mathrm{kms}$ away South-East of the Capital in summer and as much as $40 \mathrm{kms}$ away in winter, extending well beyond the boundaries of the agglomeration.

Beside the above mentioned emission sources, there are special local mezoclimatic conditions for the formation of a "London type" smog of acidic character. Smog is not produced by the prevailing North-Western winds as has been suggested earlier. These strong turbulent winds, though they bring in the smoke from the Óbuda industrial plants, sweep them out of the city in no time. The relatively rare laminal winds from the South-East are the ones that drive the smoke from the industrial plants of Kelenföld, Csepel, Ferencváros and Köbánya over the densely populated central city core and the polluted "air mass" is forced to pile up in the foreground of the Buda-mountains.

Taking into account the topography, the frequency of winds and the direction of the prevailing winds, the North-Eastern section of the Capital is the most suitable for the location of industry.

\subsection{THE POTENTIALS OF THE BIOSPHERE}

The deterioration of the bisophere is a sure indication of the general degradation of the environment. The principal aim of environmental development in the Budapest agglomeration is the creation and enlargement of bioactive surfaces covered by natural greenery, as against the dominance of man-made built-up areas. 
A) Possibilities of immediate further development of the biosphere:

1. the creation of a horse-shoe shaped forest zone surrounding the city with the extension of existing forests and the planting of new ones;

2. natural and landscape features to be protected are: floristic, faunistic and geological specialities by the demarcation of districts of landscape protection;

3. the preservation and creation of parks and groves within the inner areas;

4. the creation of zones of greenery isolating industrial from residential areas and also areas occupied by communication lines.

B) The possibilities of developing green areas based on hydrospheric potential where it provides more moist surroundings:

5 . the utilization of the belt along the riverside, running in the direction of the North-South axis of the Danube, for holiday and recreational purposes;

6. within the horse-shoe shaped forest zone a green belt along the small streams, to be used for public purposes (sporting grounds, play-grounds) public institutions (hospitals), or perhaps production oriented activities (intensive gardening);

7. south of the agglomeration the water-filled quarries and green areas lying between the Danube-Tisza Channel are possibilities for the development of holiday and sporting pursuits.

C) For a better utilization of the climatic and topographic potential:

8. mountains in the vicinity of the city with peaks and summit levels of $300-350 \mathrm{~m}$ have a valuable micro-climate for the planting and growing of forests; this should be utilized. By the preservation of the forest, rest and week-end recreational facilities could be ensured;

9. the cooling effect of the Danube especially in the center of the city and the islands;

10. the intensive agricultural use (orchards, especially stone fruits) of hill slopes with a Southern exposition for building weekend country houses and the allocation of small weekend estates.

\section{ENVIRONMENTAL POTENTIAL AND}

\section{THE PLANNING OF LAND UTILIZATION}

The general plan of the development of the agglomeration stated the main policies and objectives of land utilization. Beside marking out a future polycentric city structure, it also indicated the several new dynamic axes of city development (Szentendre, Dunakeszi, Kistarcsa, Érd). It outlined the main utilization tendencies until the turn of this century, considering the various demands for the foreseeable future.

However, when determining the use of land, the natural potentials offered by the environment were only partially considered. In the remaining part of our lecture we sould like to reveal some of these problems. 


\subsection{AREAS OCCUPIED BY PUBLIC INSTITUTIONS}

With the development of society and the rise of living standard the number of public institutions and those performing central office functions is expected to rise. This does not mean, however, that it is always accompanied by a greater areal or space requirement. The center of the Capital has so "far retained its residential function, and thus the city" in its classical sense has not developed. The task to be performed above all is the easing of the burden on the city center, solving the problem of overcongestion there. There are different ways and means to stop this overcrowding. These are:

1. The reconstruction of the downtown area with a more intensive land utilization.

2. The "extension" of the downtown area; namely the extension of some of the central functions to the inner city zone stretching as far as the Great Ring Road (Nagykörút).

3. To form a "system of centers" so as to make the presently monocentric Capital into a polycentric one. The new city centers marked out are: Újpest, Zugló, Kispest, Lágymányos, Moszkva square, Óbuda. The "decentralization" of the city center, in this manner, is carried out in close accordance with the development of the communication network (subway and urban expressways).

\subsection{RESIDENTIAL AREAS}

The residential areas of the Budapest agglomeration are relatively loosely built-up. Thus even at the expense of some reconstruction, there is the possibility on these very areas for more intensive building. Both in the Capital and also in the agglomeration zone, therefore the residential areas should grow only to a limited extent.

According to the plans by 2000 , the shortage of housing will be eliminated by the building of 400,000 new flats. This is mainly possible because of the modern method of assemblage from prefabricated concrete blocks. Largescale housing in the capital will be made up of spatially concentrated units. Houses to be built will be divided almost evenly between the following types.

1. One quarter (about 100,000 new flats) would be built as part of the reconstruction of the city's outdated inner sections (Józsefváros, Erzsébetváros, Belső-Ferencváros, Angyalföld). Clearance of the quarters, which have become slums with their inadequate social hygienic conditions, and poor public amenities is absolutely necessary.

2. A further quarter of new building is connected with the reconstruction and modernization of suburban centers (Újpest, Köbánya, Kispest, Csepel) in accordance with the formation of polycentric city structure.

3. The third quarter includes the building of new residential blocks in the open spaces of the outskirts (Kőbánya, Ûjhegy, Órmező, Békásmegyer, Káposztásmegyer, Újpalota) that will form new residential neighbourhood. The construction of these ten to twelve storey apartment blocks may involve extra expense because of the ground work necessary at some locations. Building these areas is indispensible, since only then can adequate rehabili- 
tation be carried out in connection with the reconstruction of the inner districts. When marking out the site for these residential areas, the town planner already had a very limited choice.

Though economically this plan may be advantageous, from the ecological point of view it may not be right. For example, the location of the KobbanyaUjhegy residential area may be justified economically. However, it lies between two important industrial zones (air-pollution), close to Ferihegy airport (noise), and it is also partly undermined. The building of a residential neighbourhood with tall apartment blocks under these conditions must be examined critically from the point of view of Environmental Protection.

4. The last quarter is the building-up of the mountainous area (Szabadsághegy, Hármashatárhegy, Arany-hegy). We do not fully agree with this either, since it is at the expense of the forests of the Buda mountains. Preservation and expansion of these is a vital environmental planning and developmental task in the Capital and its vicinity. The forest ecosystem disturbed in this way are far from being of equal value even compared with the already greatly deteriorated forests of the Buda mountains, though there are significant green areas left among the apartment blocks. No residential neighbourhood should be planned for the slopes of the Buda mountains. The building of only family houses with large gardens and rest houses should be permitted on the steep slopes, with strict implementation of protectional measures against soil and surface erosion.

Within the outer zone of the agglomeration the bulk of houses would be built as family dwellings. The more dense urban type of housing in towns (Dunakeszi and Érd), or chosen centers of a settlement group (Kistarcsa, Szigetszentmiklós) would be concentrated in the inner, central areas.

As a result of these new housing schemes, the intensity of built-up areas will increase at the expense of presently loosely built-up areas. The area of the Capital is $525 \mathrm{~km}^{2}$, out of which $185 \mathrm{~km}^{2}$, 35 per cent will be occupied by residential areas. By the turn of this century the ratio between the various residential area categories and that of the population expected to live there, will be the following:

\begin{tabular}{|c|c|c|c|c|c|}
\hline Type of residential area & $\mathrm{Km}^{2}$ & Per cent & $\begin{array}{c}\text { Thousand } \\
\text { persons }\end{array}$ & Per cent & Persons/ha \\
\hline $\begin{array}{l}\text { Densely built-up urban } \\
\text { Loosely built-up urban } \\
\text { Family houses }\end{array}$ & $\begin{array}{r}32 \cdot 4 \\
43 \cdot 7 \\
109 \cdot 3\end{array}$ & $\begin{array}{l}17 \cdot 5 \\
23 \cdot 6 \\
58 \cdot 9\end{array}$ & $\begin{array}{l}970,0 \\
655 \cdot 0 \\
435,0\end{array}$ & $\begin{array}{l}47 \cdot 0 \\
32 \cdot 0 \\
21 \cdot 0\end{array}$ & $\begin{array}{r}300 \\
150 \\
40\end{array}$ \\
\hline Total & $185 \cdot 4$ & $100 \cdot 0$ & 2060,0 & $100 \cdot 0$ & 180 \\
\hline
\end{tabular}

\section{INDUSTRIAL AND WAREHOUSE AREAS}

Experience has disproved the outdated concept that the industrial predominance of the Capital and its surroundings could be terminated by forbidding the location of new industries in the Capital. The development plan revised in 1970 proposed an intensive and selective development policy for industry. 
This means an increase in industrial production with a corresponding decrease in the number employed (intensification); the relocation of industries that are not based on skilled labour and those factories that cause air pollution (selection). New industries would be established in "industrial estates" with ready infrastructural amenities so as to reduce investment costs and to ensure a rational functioning. Modern industrial plants have a far greater space requirement than those crammed in, during the industrial boom of the last century, and congested further since then. As a result a twofold increase is expected in industrial areas.

Taking into account environmental considerations, areas South of the Capital along the Danube valley are to be recommended (Nagytétény, Csepel, Soroksár). To ensure an even distribution of industrial establishments the further development of Óbuda, Rákospalota, Rákosvölgy, Kóbánya, is possible provided the sanctions of environmental protection are enforced, and the purification of air and water is radically solved. Greater attention should be paid to the separation of industrial and residential areas, and the planting of protective greenery between them.

\subsection{AREAS OCCUPIED BY COMMUNICATION}

The historically developed communication network of the Capital falls short of the requirements of modern communications; it is already outdated. This is not only shown by congested streets and traffic jams, but it also leaves a great number of tasks to be performed in the field of environmental development.

1. The country's road netsyork is centered on Budapest and as a result nine national and one continental highway pass through the central core of the city. The congested densely built-up inner districts of the city are choked by exhaust gases (hydro-carbons and carcinogenic lead compounds), and the harmful sound effect experienced has stabilized at 75-80 decibels, well above the normal, healthy limit of tolerance. The only solution for this problem is the construction of the planned outer circular expressway running along the boulevard Hungária körút.

2. The circular railways and stations formally situated at the city borders have been overtaken by the expansion of the built-up areas of the city. The vibrations caused by locomotives and their sound effect, not to mention the soot and smoke from the engine houses at the railway stations, have all turned these places into the most unhealthy areas within the city.

3. Budapest airport is situated at the South-Eastern border of the Capital. The air-route to Ferihegy passes over the city, which means that noise exceeding 80 decibel is not only heard in neighbouring Kőbánya, but also in the more distant residential districts of Angyalföld and Zugló. The taller the houses, the greater the harmful effect of the noise. In the nearby areas of the airport the 95 decibel level of noise has become permanent. For economic reasons the airport is to be enlarged at its present site, so there is little hope that the noise level created by air traffic will be lowered in the Capital as a whole. 
4. The existing and planned subway network will be able to solve the problem of mass transportation. The underground lines spreading radially towards the outer centers and the periphery of the city, will connect these areas via the city center, linking the two central railway stations of the Capital as well.

\section{THE ORGANIZATION OF SPACE WITHIN THE BUDAPEST AGGLOMERATION}

Budapest is structured in a typically monocentric way. The institutions performing central functions of administration, commerce, education, culture, entertainment and tourism, are all concentrated in the central core of the city. Formally it has been accepted that by developing all the outer districts as fast as the central ones, the oversized central city core can be counterbalanced. This has led to the dissipation of all financial efforts. Efforts such as the decentralization of the location of institutions, the improvement of communications, and the building of new residential districts since Hungary's Liberation, have not been effective enough in creating urban centers in the outer districts. In the vicinity of the city, due to a significant immigration, the standard of basic provisions falls short of those in settlements with a similar number of inhabitants in the country.

The task to ease the "burden" carried by the central core is well known in all big cities of the world. The solution to the problem, however, varies with local conditions. There are three ways to solve this in Budapest: 1 . modernization of the city center, 2. expanding the city center at the expense of neighbouring areas, and finally, 3 . formation of peripheral local centers.

\subsection{CENTERS OF DEVELOPMENT}

\subsubsection{Modernization of the city center}

The aim of the 1968 plan for the reconstruction of the downtown area is the intensive development of this principal national center. Its first task is to reorganize the "crippled" transport in this area. Mass transportation from the peripheries is ensured by two new underground lines that intersect in the downtown area. From the point of view of commerce and pedestrian traffic, planned pedestrian precincts will be of importance, and for the tourist trade planned new line of hotels along the Danube. The plan insists on preservation and possible enlargement of green areas where it can be done.

\subsubsection{Expanding of the city center}

The reconstruction of the town center will be unable to cope with the greatly increasing tasks to be performed; therefore the expansion over neighbouring areas is unavoidable. The general plan of reorganization includes the reconstruction with green areas of the crowded slum between the Small Ring Road and the Great Ring Road (Kiskörút and Nagykörút). 


\subsubsection{System of centers}

The decentralization of functions from the monocentric city-center is the third and most effective way of changing the structure of the agglomeration into a polycentric one. Some of the central city functions are thus taken over by local centers. The following scheme should be adopted for the Capital and its vicinity: the "city sectors" (not the administrative districts!) around the central core should have "sectoral centers", and for the agglomeration zone, service centers for a group of settlements should be formed.

A "city sector" can be defined as an area embodying several districts, with a few hundred thousand inhabitants, more or less autonomous, with partially independent functional units. At present, development is carried out within district boundaries but the experiences of the past two decades show that this directive has not prove effective for the implementation of decentralization. The sectoral centers including several districts are: on the Pest side: Újpest, Zugló, Kispest, and on the Buda side: Óbuda, Moszkva square, Lágymányos.

The 44 settlements of the agglomeration zone of the Capital have been grouped into nine settlement groups. In future planning these nine groups will be considered as units and subordinated to their settlement group centers. Settlements with central functions are the following [the number of the settlement group is in brackets]:

On Buda side: Érd [I], Solymár [II], Szentendre [III];

On Pest side: Dunakeszi [IV], Kistarcsa [V], Maglód [VI], Vecsés [VII], Dunaharaszti [VIII] and Szigetszentmiklós [IX].

Development is focused on the above listed local centers.

\subsection{MAJOR AXES OF DEVELOPMENT}

Possible future lines of development are determined by the system of hierarchical centers to be established within the area of the agglomeration, plus the historically developed Budapest-centric communication network and topography. These lines join the centers situated along the most dynamic axes of growth, and thus open up the basically closely structured agglomeration. These axes of development in the long run will be more than just communication lines, they will form specific belts. Industrial and residential building constructions within these belts would - and stemming from dynamic development they should - cross the lines of present administrative boundaries. In this way structural change within the inner areas of the agglomeration is secured, and also the further development of the capital and its surrounding is guaranteed. The revised plan confirmed last year, adopted four main lines of development. These are:

South Buda: Lágymányos-Ốrmezô-Budaörs (in the western direction towards the Balaton)

North Buda: Óbuda-Békásmegyer-Szentendre-Dunakanyar (holiday resort)

North Pest: Újpest-Dunakeszi-Vác (industrial)

East Pest: $\quad$ Zugló-Kistarcsa-Gödöllő. 
I e special development of the already crowded South-Eastern "tentacle" is not justified (Ferihegy airport).

\subsection{LAND UTILIZATION}

The detailed plan of reorganization stated the long-term perspectives of land utilization. In the course of working out this plan, the social requirement and the environmental potential have both been carefully examined.

According to the prognoses by demographers the population of the agglomeration will increase from the present 2.4 million to 2.8 million by the turn of the century. The proportion of people of working age will decrease and also the number employed in the industrial sector. Technical development and the resulting rise in living standards and ecological expectations all point to a far more significant claim on space than there is today.

Modern industry requires more space than is allocated presently because of technological and hygienic considerations. This is already acute in the case of most industries of the Capital and factories are located far too close even in terms of present space requirements. More space is needed for improving the quality in housing (better airing and more light), and the improvement of services related to housing (parking places, free areas). With the improvement of communications and a rapid growth in the number of private cars, the demand for family type housing is expected to rise. Interest shown in holiday resorts will increase greatly. The creation of a continuous areally extensive system of green belts should provide the necessary green areas for the relaxation of the inhabitants and for Environmental Protection purposes. The fulfilment of all these space requirements within the area of the agglomeration can only be satisfied at the expense of agricultural land use or by intensive building in the presently still loosely built-up districts. 
(.) 


\section{NORTH AMERICAN RESEARGH CONCERNING \\ THE EFFECTS OF URBANIZATION \\ ON LOCAL AND REGIONAL WEATHER AND CLIMATE}

By

WILLIAM P. LOWRY

\section{INTRODUCTION}

My intent in this paper is to present a personal assessment of North American research into the effects which cities and their industrial activity have upon weather and climate in and near the cities. In the presentation, I shall report on the consensus held on the subject by North American climatologists ten to 15 years ago, the significant research done in North America after that time, and my view of the consensus as it exists today. Following that, I shall present a critical analysis of today's consensus together with my own views on the ultimate utility of firm knowledge about urban climates, and on the research problems most urgently in need of solution in view of the ultimate use of the knowledge.

Before undertaking the presentation, I shall need to discuss definitions of several terms which are in common usage among urban climatologists. Urban climate ought to mean approximately "the ensemble of values of the various weather elements as they are observed in an urban area". The ensemble of values, of course, may include the mean values, measures of variability about the means, the sequences of values from hour to hour, day to day, etc., or all of these.

The presence of an urban surface where once the surface was "rural", or non-urban, usually changes the values of the weather elements, for a given large-scale weather situation, from what their pre-urban values would have been. These differences, or increments, themselves form an ensemble properly called the urban effect on local climate. Within some distance from the urban area, values of the weather elements at non-urban sites may be changed by the presence of the urban area nearby. The ensemble of resulting differences at these non-urban sites, caused by the presence of an urban area, is to called the urban effect on regional climate.

Unfortunately, urban climatologists have fallen into the habit of expressing urban effects as differences in values of the elements between those observed at urban sites and those observed at nearby rural sites. While this urban-rural difference is a reasonable approximation of the urban effects on local climate, and therefore gives some insight into that part of the urban climate caused by the urban surface, it is only an approximation. It is usually necessary to settle for this approximation of the urban effects on local climate since weather records from pre-urban times are not available. Nevertheless, the approximation represented by contemporary urban-rural differences includes the effects of (a) local topography, (b) local shoreline configurations, and (c) the effects of the urban area on the nearby rural sites themselves, to mention 
three sources of error. The problems associated with the recognition and correction of these errors will be discussed later in this paper under the subject of research most urgently needed.

\section{THE NORTH AMERICAN CONSENSUS DURING THE EARLY 1960's}

As Peterson (1969) correctly notes, the standard North American review of urban climatology, and the standard statement of the consensus during the early 1960 's was to be found in the two articles by LANDSBERG $(1956,1962)$ which presented many of his own analyses and the results of those by other workers. LANDSBERG mentions several remarks about urban effects made by Americans in the early 1800 's, but makes it clear that American urban climatologists accept the classic European works by Howard (1833) and KraTZER (1937) as the major roots from which later research grew. Documentation of that growth after HowARD is to be found in the annotated bibliography of C. E.P. Brooks (1952) published by the American Meteorological Society.

\section{TABLE I}

Weather changes resulting from urbanization

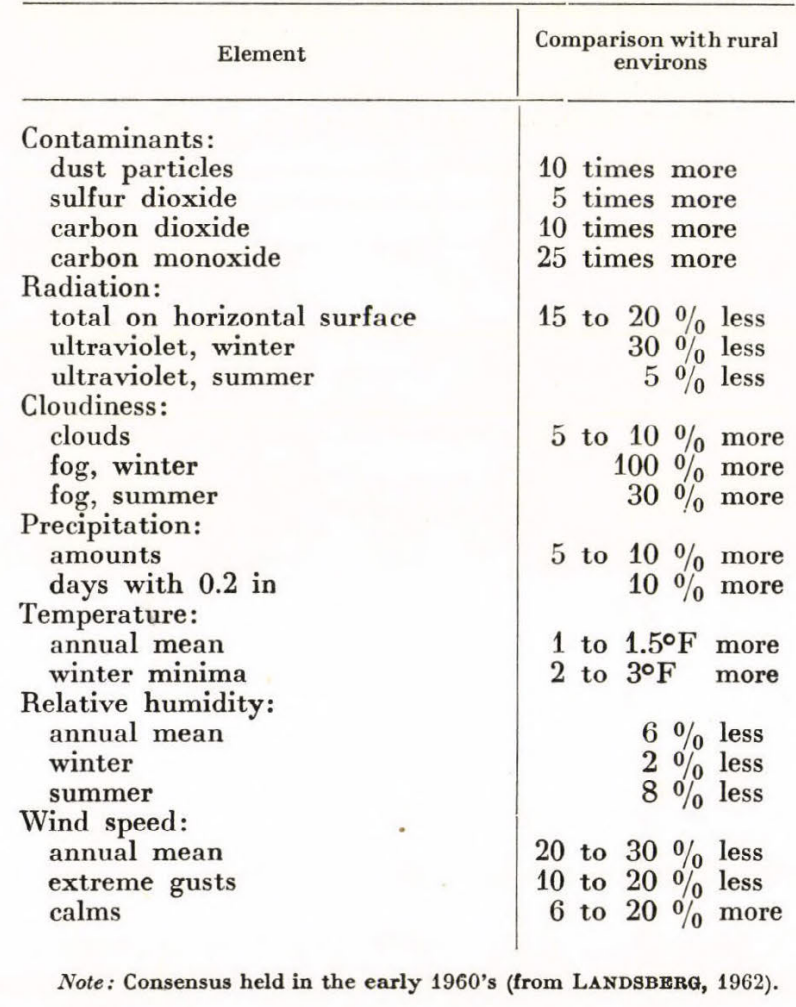


While LANDSBERG in both his classic papers cautions against forgetting that "urban-rural differences" (see definition given above) are only approximations of "urban effects on local climate" (see definition), and against trying to generalize about cities whose true effects are unique, each to each, his own table offering such generalizations is usually the only item brought forward from those papers into present discussions. That table is reproduced as Table $I$ of this paper. The reader should note that the table expresses the outcomes of urban effects almost entirely in terms of variables as they are observed at points in the "human space" at or very near the earth's surface. The references to cloud are the only possible exception, but even these speak mostly of fog in the human space. The vertical and the temporal dimensions of the urban effects are scarcely suggested.

\section{CAUSES OF URBAN-RURAL DIFFERENCES}

The view of urban climate seen in Table $I$ is crude and one-dimensional when compared with today's consensus, and the causal mechanisms for these effects as proposed in the early 1960's were likewise crude and simplistic when compared with today's. LANDSBERG (1956) assigns the underlying causes to three categories: changes in the physical nature of the surface by urbanizationadditions of anthropogenic heat in the city; and changes in the aerosol con; tent of the urban airspace. In a slight elaboration of that list, LowRy (1967)
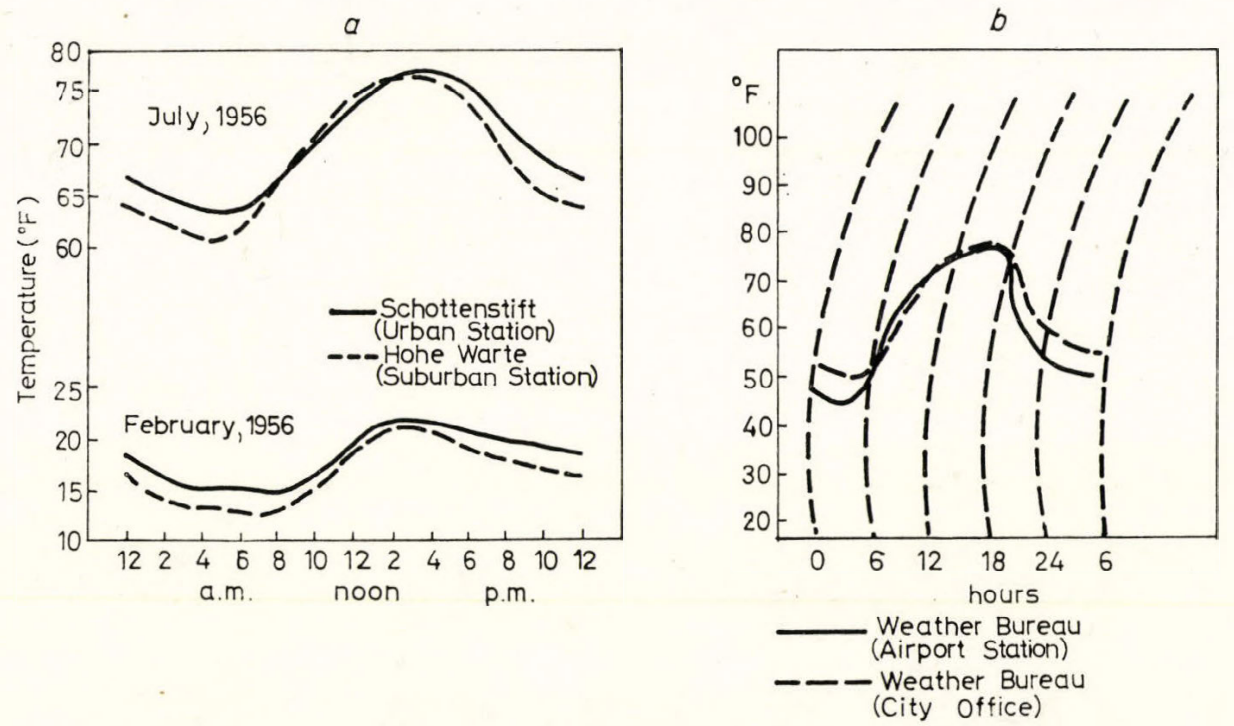

Fig. 1. Diurnal temperature traces from urban and rural stations

$a=$ Vienna (from MrroHrLL, 1962); b = Richmond, Virginia, clear day in summer (from LANDsBERG, 1956) 
suggests (1) changes in the shape of the urban surface, (2) changes in the heat absorbing, conducting, and storing characteristics of the urban surface, (3) changes in the water balance of the urban surface, (4) additions of heat by man's activities, and (5) changes in the aerosol content.

The suggested mechanisms through which the underlying changes act to produce the effects of urbanization were quite reasonable considering the general lack of proper observational data and modern theory about mesometeorological processes available in the early 1960's. These mechanisms may be discussed for each of the principal weather elements separately.

Temperature. In addition to the differences about temperature contained in Table I, the early consensus held that the diurnal temperature march in the city bore the relationship to the rural march shown in Figures $1 a$ and $1 b$. Maps of the "urban heat island", based primarily on the work of DUCKworTH and SANDBERG (1954) in California, gave a spatial component to the consensus. The relationships in Figure 1 were explained as the net results of several interactions producing (1) a thermostatic reduction in the day-to-night temperature range added to (2) a general warming within the city.

Causes of the thermostatic reduction were suggested as the effects of air pollutants on the radiation balance, the additional heating in the city at night, and release of heat from urban surfaces at night following storage of solar heat there during the previous day. Causes of the general warming both day and night were suggested as the release of anthropogenic heat from dwellings, automobiles, and factories; the lower albedo of the urban surface due to internal reflection/absorption between buildings; the reduction in evaporative cooling by vegetation in the city; and the less effective removal of any excess heat by winds of reduced speeds.

DUCKWORTH and SANDBERG (1954) reported a series of wiresonde observations of the structure of temperature in the air layers several thousand feet above both urban and rural surfaces. They attempted to generalize about the form and depth of the part of the boundary layer which was being affected by the presence of the urban surface, but they favored no one of the several explanations they had suggested for the observed modification. As to the depth of the modified layer, they would say only that the city "has an influence extending to appreciable heights and capable of causing atmospheric instability in a shallow layer over a city." Although these few observations constituted part of the consensus held in the early 1960's, the vertical aspects of the modifications caused by the urban surface were scarcely ever mentioned in the consensus and clearly not so important to reviewers as the differences produced within the human space of the city.

Precipitation. As Table I shows, cities were believed to receive about 10 per cent greater totals of precipitation than were received in surrounding areas. The attention was to this difference between the city and the near environs, and it was believed that most of the urban excess was an accumulation of slight increases in amount on relatively stable, generally "drizzly" days when only small amounts were received anywhere in the region.

Changnon (1962) suggested changes in total precipitation caused by the city are due to a combination of additional aerosols acting as nuclei in formation of cloud droplets, of thermal turbulence due to the greater roughness 


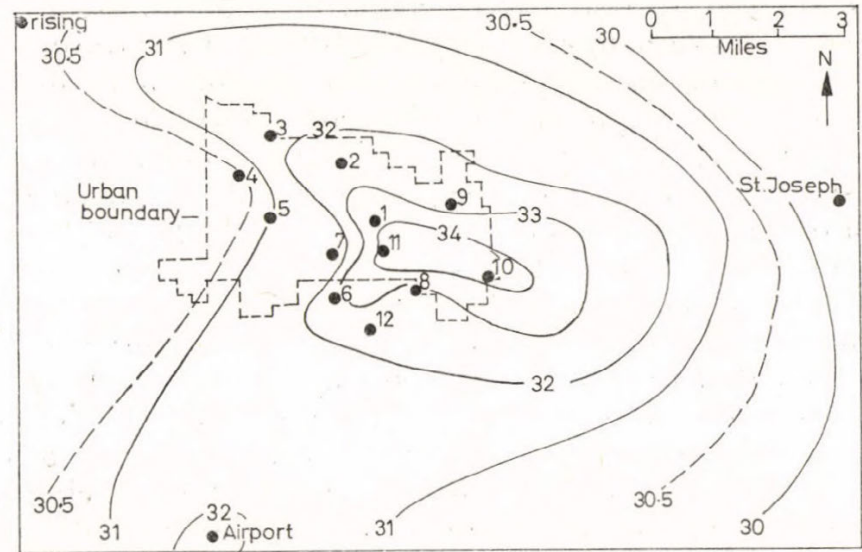

a) Average annual precipitation for 1950-1959, in inches

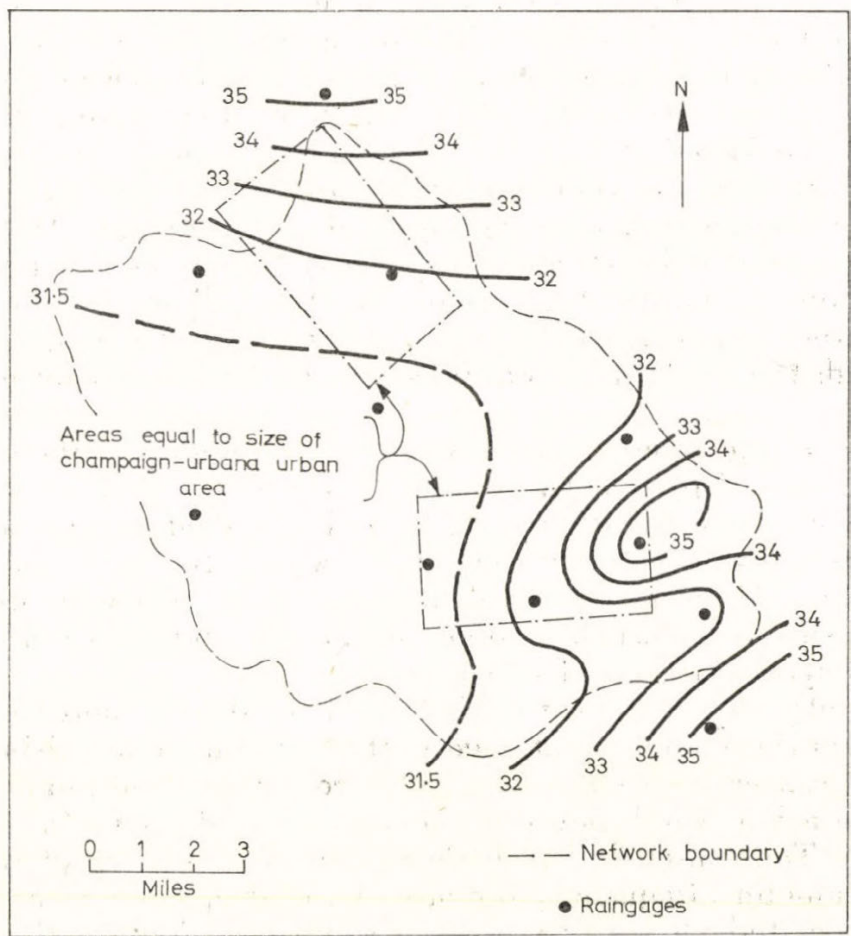

b) Annual average precipitation on Panther Creek raingage network, $1950-1959$

Fig. 2. Mean annual precipitation patterns

$\mathrm{a}=$ around an urban area of 80,000 population; $\mathrm{b}=$ in a nearby rural area without major topographic features (from CHANGNON, 1962) 
of the urban surface. In that paper, presenting the results of special observations in the area of Champaign-Urbana, Illinois, CHANGNoN mentioned in passing that urban effects on precipitation totals might be evident "downwind" of the city, but they had found no particular evidence for that in his study. Also in that paper, CHANGNON offered a convincing argument that the natural spatial variability of precipitation totals in central Illinois was of the same relative magnitude as the spatial variability found around the cities he studied. Thus, he cautioned, local excesses or deficits which one might wish to attribute to cities might actually be caused by processes completely unrelated to the presence of cities. All the same, several other of his analyses suggested to him that the city did indeed play an active role in the determination of the local precipitation processes. Maps showing the "natural" spatial variability and the "urban" spatial variability in CHANGNON's paper are offered here as Figures $2 a$ and $2 b$. On balance, CHANGNon concluded that cities were producing an increase in precipitation totals slightly downwind of the city center but still within the urban area, and that the urban effect was not clearly separable in the data from other, unspecified effects.

Wind. The frictional drag of the rough urban surface on the regional windstream was offered as the explanation for the reduction in average and gust speeds and the more frequent calms in a city. The consensus also held that, under conditions of very light regional windflow, a city induced a local wind system which consisted of a torroidal flow: inflow from all directions near the surface, a gentle rising motion above the center of the city, and outflow aloft to complete the circulation over the surrounding countryside. While these two conclusions seemed quite tenable, they hardly represented a complete view of wind behavior, ignoring, for example, the three-dimensional nature of the wind field when regional winds are not light. The attention, again, was directed towards the wind behavior as it would be sensed at a point in the human space within a city.

Relative humidity. Average values of relative humidity in the city were observed to be several percent less than values in rural areas nearby. This difference was found consistently among the cities studied, and it was attributed simply to the absence of free water sources within the city: soil, vegetation, and waterways. The consensus had little to say either about differences in absolute measures of moisture content (such as absolute or specific humidity) or about the spatial aspects of moisture.

Cloud. Clouds other than fog were believed to be slightly more frequent above cities, being initiated and maintained in the column of air rising above the warmer city center both day and night. From these additional clouds, the extra precipitation was believed to come, as noted above in discussion of precipitation. The consensus had little conclusive to say about the effects of cities on the amount, frequency, and intensity of deep cumulus cloud activity, or about associated phenomena such as heavy rain, hail, or thunderstorms.

\section{SUMMARY}

As has been suggested, the consensus held in the early 1960's about urban effects on weather elements addressed differences between the ground-level 
places in cities and rural areas, with scarcely any consideration of the vertical dimension. Differences in averages, rather than time trends, were given almost exclusive attention. Although averages were separated by seasons, concern for the way values changed as cities grew was largely ignored in all but a few temperature studies (MTTCHELL 1962). An intriguing idea was pursued by MitchelL (1953) when he separated averages of temperature for weekdays (Monday through Friday) from those for weekends. Smaller urban-rural differences on weekends were believed to be evidence that the differences were caused by the city. LANDSBERG (1956) noted a similar result for weekends in records of precipitation totals for Rochdale, England, but in general temporal aspects of urban effects were ignored.

This report of the consensus of the early 1960's is, of course, necessarily brief, ignoring many details and failing to mention many important individual studies. The intention that it show the simplistic and incomplete nature of the evidence and of the synthesis of the evidence is, however, probably fulfilled. Thus, this summary will probably be most instructive when it is later contrasted with the consensus held today.

\section{SIGNIFICANT NORTH AMERICAN RESEARCH OF}

\section{THE LAST DECADE}

During the decade 1965-1975, North American urban climatologists were joined in their interest in the subject of urban effects on weather and climate by researchers from other parts of the Atmospheric Sciences. In one research mode, existing climatic records were analyzed to detect urban effects, and the various results previously published were collated into new empirical models and new ideas about the causes of urban effects. In another research mode, entirely new kinds of data were gathered in field expeditions, involving not only very sophisticated instrumentation but also the regular use of aircraft to sample the lower boundary layer over and near urban areas. In still a third research mode, computer analyses and simulations of the atmospheric physics and dynamics of urban regions were pursued with vigor.

This intense activity and the progress it produced were documented in many ways. To this writer the most significant "events" in this documentation were the following five:

(1) Publication by Changnon (1968) of his analysis of the "LaPorte anomaly", which appeared as a region of excessive precipitation totals and higher frequencies of severe weather elements located near the town of LaPorte to the east of the Chicago-Gary urban complex in the American Midwest. Publication of various comments on this paper, and of CHANGNON's replies to the comments contributed to this event.

(2) The publication of an annotated bibliography on urban climates (CHANDLER 1970) and the convening of a Symposium on Urban Climates and Building Climatology (WMO 1970) by the World Meteorological Organization.

(3) The convening of a Conference on Urban Environment by the American Meteorological Society (AMS, 1972). 
(4) The initiation in 1971 of a comprehensive, multi-agency research program, with field studies centered on the urban region around St. Louis in the American Midwest, given the name METROpolitan Meteorological EXperiment (METROMEX) and the subsequent publication of various results from that programme (LOWRY 1970).

(5) The publication of a review of research in urban climatology by the World Meteorological Organization, covering work published in the period 1968-1973 (Oke 1974) as a supplement to the Proceedings of the Symposium in (2) above.

Before reporting something of the nature and content of the significant research of the last decade, I wish to return for a moment to the matter of definitions raised in the introductory section of this paper. Urban climate, as was stated, is the ensemble of values of weather elements observed and experienced in an urban area. For various reasons, these values are often contrasted with values of the same elements as observed in nearby rural, or nonurban areas. The detection of differences between these values, of course, prompts questions about the causes of the differences, presumably with some ultimate utility in mind for knowledge about causes. Quite understandably, pursuit of answers about causes has led urban climatologists to investigate the nature of the modification of the atmospheric boundary layer above and downwind from urban surfaces. That is, urban climatologists have undertaken to understand the nature of a physical system in which an urban surface plays a crucial role. Despite this, it is the ensemble of values of elements, representing only the outcomes of the workings of the physical system, which constitutes the urban climate.

As a generalization, then, most of the research in the last decade has been directed towards understanding the ways in which an urban surface modifies that physical system which produces the urban climate. This is as it should be, since most of the earlier works dealt with the expression of climate and with speculations about causes which could not be tested. Since this paper is nominally concerned with climate and not with process, I shall try to dwell more on the improvements in delineating urban climate and less on the details of the many significant studies which have improved our understanding of causal processes.

In examining existing climatic records from states surrounding Illinois, for purposes of delineating the correct extensions of climatic patterns across the boundaries of Illinois, Changnon and his co-workers encountered an area east of Chicago, centered on LaPorte, Indiana, where records indicated extraordinarily large totals of precipitation and high frequencies of severe weather occurrences. In describing this LaPorte weather anomaly, CHangnon (1968) for the first time injected into urban climatology the idea that urban effects on precipitation may be experienced as effects on regional, rather than local, climate (see definitions above). The idea had been suggested before, but never so clearly and convincingly. Thus, the concept was suggested that urban effects on precipitation climate will be experienced in precipitation measured at the earth's surface only a certain time, and therefore a certain distance along the airstream, after the impulse from the urban surface had moved upward into cloud systems, through the precipitation-forming processes 
within the cloud systems, and down again to the earth where the precipitation was sampled. The exact causal mechanisms were only to be guessed, but Changnon's study of the Chicago-to-LaPorte region led to an important series of such analyses of existing climatic data on a regional scale, rather than on the local scale used in almost all earlier studies.

The published discussions of Changnons' paper (see notes following reference to Changnon 1968) led to a greater appreciation among urban climatologists of the need to examine all possible hypotheses and many different analyses of the same data in the search for an urban effect, of effects, which are clearly "buried" among many other kinds of natural variability and effects. Such non-physical effects as the possibility of observed bias were raised by commentators as hypotheses which must be examined in addressing the question of the reality of the LaPorte anomaly. Such indirect evidence as stream flow and tree ring patterns in the LaPorte region were examined for indications of support for the reality of the LaPorte anomaly, completely aside from any considerations of its causes. The reality of the anomaly at LaPorte did not emerge clearly in the minds of all investigators, and even in the minds of those most convinced, separation of effects probably due to the shoreline of Lake Michigan from those possibly due to the urban area upwind was very much in doubt. CHANGNON attributed increases in precipitation totals near 30-35 per cent in the LaPorte area - several times larger than any increases previously attributed to urban areas, within the city boundaries themselves. CHANGNON readily conceded that shoreline effects were at work, quite possibly increasing the size of an otherwise modest addition around LaPorte, but the search was undertaken at once for other regions in which analysis of existing weather records could provide a broader base of examples of the phenomena in question.

The results of that search have been reported recently (HUFF and CHANGNON 1973). While areas of relatively large precipitation totals were found near or downwind of most of the eight American cities studied, and while all those areas exhibited "increases" lying in the general range of 10-15 per cent, there was little consistency in the matter of distance from the urban center (distances cited were between "near urban center" and "80 km downwind"), and two of the cities (Indianapolis and Tulsa) did not clearly exhibit a pattern of increases nearby.

I wish to remark at this point that the demonstration of an area of relative maximum in seasonal or annual precipitation totals near or downwind of an urban locality by no means demonstrates that the urbanization is the cause of the maximum. It is a fact, all the same, that many writers on this subject of the empirical evidence for urban effects on precipitation refer to such areas as areas of "increase" or "downwind urban effect areas" or other similar terms. Studies such as these by HUFF and CHANGNON have evoked vigorous efforts to devise and test techniques for extracting from the existing climatic records those changes in the regional patterns of precipitation, if any, which can reasonably be related to the existence of nearby urban surfaces. These efforts continue at the present, primarily within the research group of which CHANGNON and HUFF are members: The Atmospheric Science Section of the Illinois State Survey, in Urbana, Illinois. 
The Symposium on Urban Climates, convened in Brussels in October 1968 by the World Meteorological Organization, and reported in a Proceedings published in 1970, brought forth several new kinds of research. Among the North American scientists who participated, there was an emphasis on analyses of data gathered especially for research in urban climatology and of appropriate data gathered for special purposes other than those of the national archive from which the data used by CHANGNON and HuFF generally came. Investigations of the thermal climates of towns and their environs reported at this conference were based principally upon data gathered especially for the purpose. Work on the nature of windflow in and near urban areas was based principally upon data gathered for other purposes. Much of the research reported was concerned with the presence and movement of air pollutants in cities, and to the extent that air pollutants provide ready tracers of air motions, this work provided information with which to address questions about the effects of the urban surface on local atmospheric motions.

At the time of the Brussels Symposium, studies had accumulated to a sufficient extent that several sets of data could be merged in attempts to discover general principles and patterns of urban climate and urban effects on local and regional climates. Two outstanding examples of this kind of effort are those of LUdwig (1970) and of OkE and HANNEL (1970). Ludwig pooled data from many studies by himself and others into a statement that the urban-rural difference in air temperature (see definition above) between the center of the urban heat island and a typical rural area, $\Delta T$, is a linear function of the lapse rate of temperature above the rural surface, $G$, which is defined as the number of ${ }^{\circ} \mathrm{C}$ of temperature decrease for each metre of height increase above the surface:

$$
\Delta T=A-B G
$$

in which the empirical constants $A$ and $B$ are both dependent upon the pop. ulation of the city and both increase as the population increases.

OKE and HANNELL pooled data on wind and urban-rural temperature differences and concluded that the value of the wind spend, $U_{c}$, at which the urban-rural temperature difference was erased by rapid dispersion of excess heat was related to the population of the city, $P$, in a logarithmic fashion:

$$
U_{c}=1.5(\ln P)-11.9
$$

Clearly, these results represent statements about generalities of urban climate, but by no means do they represent the results of theoretical derivations based upon physical principles. As will be seen presently, however, they are quite consistent with theoretical considerations.

Several other results from the Brussels Symposium appear to me significant in the general development of urban climatology. For one, LUDwIG (1970) presented a series of midday temperature maps of several cities (most other such maps were nocturnal) based upon observations made with the aid of specially instrumented automobiles, much like the original "messfahrten" on bicycles made by German climatologists (KRATzER 1937). A consistent feature which appeared in these daytime observations was called by LUDwiG the "warm ring": a ring of warmest temperatures surrounding a slightly cooler 
core at the city center, the ring itself surrounded by cooler temperatures in the suburban areas. LUDWIG reported these patterns had appeared in daytime measurements in four or five cities he had studied. The "cool core", he surmised, was the result of shading, by exceptionally tall buildings, of street-level spaces where the temperatures were measured. Based upon principles long established by research in forest microclimates, LUDwIG guessed that the warm temperatures one expects to find at the center of a city would indeed be found at midday well above street level, between the walls of the buildings in the "urban canopy".

Clarke and MoEmroy (1970) exhibited vertical cross sections of temperature over and near an urban surface. Their observations at Cincinnati were obtained with the aid of a helicopter, and the sections clearly disclosed what is now called the "urban heat plume": a downwind drift of heated air originating at the urban surface and appearing much like a plume of smoke from a ground-level bonfire. This "plume" and its associated motion represent the extension, to cases with significant regional windflow, of the toroidal flow and "heat dome" found under conditions of negligible regional flow. This paper was the first widely exhibited demonstration of what had before been only suspected.

In the definition offered above the importance of pre-urban climatic conditions as a base from which to judge urban effects was suggested, as was the lack of proper observational records in the early historical times of places which now contain large cities. LANDSBERG (1962) presented several examples, at the Brussels Symposium, of measurements now being made at Columbia, Maryland, a town near Washington, D. C. The observational programme was begun on the site of the planned city, but before construction had been started. In addition to the regular weather elements, measurements are being made on all components of the radiant energy balance of the site. Observations are continuing today as the city grows in a planned and predictable way. The present population of Columbia is approximately 25,000 .

The Conference on Urban Environment, held at Philadelphia in late 1972 by the American Meteorological Society, brought forth evidence of several new lines of research and several important ideas. As in the case of the Brussels Symposium, the Philadelphia Conference devoted a considerable portion of its time to matters of air pollution. While, as noted above, air pollutants are certainly of urban origin and certainly have their effects on urban climates, they are not in themselves a weather element as part of the "ensemble" of climate, nor are they necessarily the most important mechanism through which urban effects are produced. For better or for worse, however, most nonspecialists think of "air pollution" and the study of it whenever they enconter the expression "urban climatology". This may be unfortunate inasmuch as concern may be too much diverted away from other components of urban climate - the components which would be present even in the absence of dirty air - by the popular interest in air pollution.

Because the vertical aspects of the air layer above cities received relatively so much attention at the Philadelphia Conference, I wish to add here a definition of the urban boundary layer: that portion of the lower atmosphere whose physical and dynamic properties are changed by the presence of an

16 Fnyedi: Urban 
urban surface. Exactly what volume of air is included in this layer, of course, depends upon which city one is concerned with, the time period of concern, and perhaps the particular property one is studying. The urban surface, for example, may affect the radiative properties of an entirely different urban boundary layer than the layer whose properties of motion it affects at the same time.

A variety of direct observations of the urban boundary layer were reported in the Philadelphia Conference. Ackerman (1972) described profiles of wind speed and direction observed at night above urban and rural sites near St. Louis. She concluded that on relatively calm nights, there was a detectable inflow of air to the city center in the surface layers, as had been hypothesized in the early consensus about a toroidal flow pattern. Further, she observed a "jetlet" of relatively fast moving air in a shallow layer centered about $400 \mathrm{~m}$ above the surface. This motion was predicted by a mathematical simulation presented to the Conference by BoRnsTEIN (1972). Thus, theory and observation had converged in some important respects.

BORNSTEIN and JOHNSON (1972) presented results of observations made in the region of New York City, in which they found evidence to support the findings reported earlier by CHANDLER (1970) for London. These two sets of results indicated that the urban-rural difference in wind speed at ground level depends to a large extent upon the speed of the general regional windflow, or more likely upon the regional weather conditions which produce the general regional windflow. That is, when regional winds are light, speeds are faster in the city than in the rural areas; whereas, when regional winds are stronger than about 5 metres per second, speeds are less in the city.

SPANGLER and DIRKS (1972) reported observations, made in the urban boundary layer at St. Louis, which exhibited a "dome" in the top of the layer above the center of the city during the afternoon hours of a clear summer day with relatively light winds. The top of the layer was featureless at about $1600 \mathrm{~m}$ above the city at sunrise; the dome appeared at midday as the top of the laver subsided to about $1200 \mathrm{~m}$ above the environs with no change in altitude above the city center; and the whole layer was inflated by about 200 $300 \mathrm{~m}$ during the afternoon so that the top of the dome appeared at about $1800 \mathrm{~m}$. Near the time of sunset, the top of the urban boundary layer again became nearly horizontal. Temperature and moisture measurements revealed an inversion just above the top of the boundary layer in which the dome appeared. The sequence of events appears here as Figure 3, taken from SPANGLER and DiRKs.

BORNSTEIN's mathematical simulation of motion and distributions of heat and moisture in the urban boundary layer is in many senses typical of several similar papers on mathematical models presented at Philadelphia. In fact, the comment was often made by participants that there had by now become more mathematical predictions of what one would find in the urban boundary layer than there were observations with which to test the predictions. That condition continues to the present.

Three critical aspects of the mathematical theory of the urban boundary layer appeared in the proceedings of the Philadelphia Conference. The first of these was the matter of the radiation balance and its effects on temperatures. 

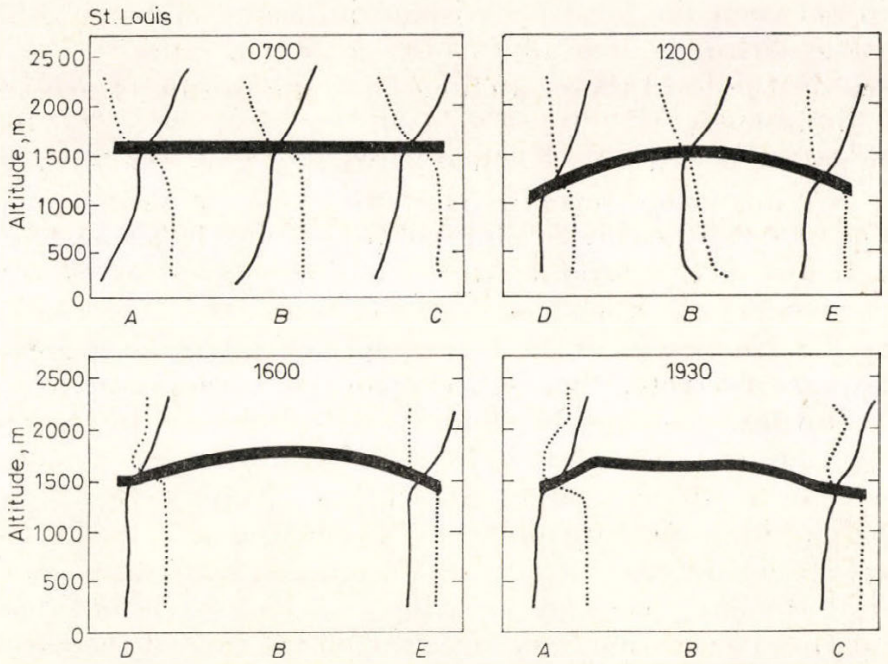

Fig. 3. Sequence of cross sections of the top of the urban boundary layer at St. Louis

Potential temperature (solid line) and specific humidity (broken line) profiles over St. Louis on 12 August 1972. Point $B$ is located in the central city area, $A$ is about $50 \mathrm{~km}$ to the SW, $C 30 \mathrm{~km}$ to the NE, E $24 \mathrm{~km}$ to the SE and $D 46 \mathrm{~km}$ to the NW. The top of the mixing layer (determined by lidar observations) is shaded (after SPANGLER and Dirks 1972)

ATwater (1972) concluded that, while the presence of pollutants in the urban boundary layer may adversely affect the ability of the layer to disperse the pollutants - an example of positive feedback - the pollutants make only a minor difference in the temperatures experienced at ground level in and near the city. A second critical point was dealt with by CRAIG and Lowry (1972) in their theoretical paper on the effects of the geometry of the urban surface on the albedo of the surface, which is the reflectivity of the surface for solar radiation. Their calculations suggested that an urban surface, containing streets between blocks of buildings, can have quite different magnitudes of effect on the albedo, depending upon the latitude of the city, the hour of the day, the materials of which walls and rooftops are made, and the turbidity of the atmosphere. The third important matter addressed by mathematical models at Philadelphia is the importance of urban land use patterns - the distribution of types of land surfaces - within the city as a determinant of the location and amount of modification of the urban boundary layer.

McELROY's (1972) mathematical simulation of the effects of various land use patterns suggests what intuition would probably have suggested: differences in locations of green areas and paved areas produce differences in the locations of cool and warm areas and in the gradients of temperature between them; but those differences in locations among surface types produce essentially no changes in the amount of contrast found within a city. This theoretical result accords well with the assertion of CHANDLER (1968), based on observations in English towns and cities, that "there is a very close statistical 
relationship between the local heat island intensity and . . urban development densities within a circle of as little as $500 \mathrm{~m}$ radius". In other words, urban effects on the local thermal climate (see definition of urban effects) are very localized indeed.

The three points which I have called "critical", and which I have just dealt with, I consider important primarily because they are ideas which have often been mentioned qualitatively in general discussions of urban climate as possible explanations of poorly understood observations or as possible justifications for considering the knowledge of urban climates to be crucial to proper urban planning. The results of the Philadelphia Conference suggest that, when considered quantitatively, these three points - radiation balance as affected by pollutants, changes in albedo, and differences in land use patterns - are intriguing but probably not of major importance in understanding urban climate or in doing competent urban planning.

The Philadelphia Conference on Urban Environment yielded some important progress in further merging of the results of several studies, and in further demonstrating the agreement between theory and observation, about the interactions of temperature, wind, city size, and the nature of the rural landscape. OKe (1972) merged results of other studies into a very satisfactory empirical relationship which he summarized as:

$$
\Delta T=A P^{1 /} / U^{1 / 2}
$$

where the nocturnal urban-rural difference in ground-level temperature is $\Delta T$ as before, the speed of the general regional wind is $U$, and the population of the city is $P$. The constant $A$ is empirical. Oke (1972), Munn (1972), and Clatrke and Peterson (1972) all remark that all available empirical evidence supports very well the theoretical derivation of SUMMERs (1965) to the effect that:

$$
\Delta T=B(H W L / C U)^{1 / 2}
$$

where $B$ is an empirical constant, $H$ is the rate of addition of anthropogenic heat within the city (energy per unit area per unit time), $W$ is the width of the city measured from the upwind edge to the downwind edge along the windstream, $L$ is the change of potential temperature with height at an upwind rural site, $C$ is the heat capacity of the urban air (energy per unit volume per degree of heating), and $U$ is the regional wind speed. Since, with a uniform density of population in a city (a condition very nearly met in North American cities according to OKE), the city width, $W$, is proportional to the square root of the population, $P^{1 / 2}$, then Oke's empirical result agrees with Summers' theory. I wish to add a comment here to the comments of these workers just cited. While it is true that the magnitude $L$ is governed by the same regional weather conditions which govern the regional wind speed, $U$, it is also true that the thermal characteristics of the rural landscape also govern $L$ in part. For example, a temperature inversion (producing a large positive value of $L$ ) is more likely and more intense over a desert-like rural landscape than over, for example, a moist and vegetated one. Thus, the nature of the surrounding landscape, in itself a reflection of the regional climate also plays a role in the "strength of the heat island", $\Delta T$. 
The multi-agency research programme called METROMEX was begun in the summer of 1971, and several of the earliest results from that programme presented at the Philadelphia Conference. The papers by Ackerman (1972) and by SPANGLER and DIRKs (1972) were based on the work of METROMEX, as were several other papers at the Conference. More recent papers contain both more recent results than those given in Philadelphia, and also a more carefully constructed presentation by METROMEX scientists of those results they consider most significant and most firmly established.

The goals of the METROMEX programme include both the establishment of the presence and magnitude of urban effects on various weather elements, both locally and regionally (see definition of urban effect), and also the investigation of the physical processes producing any effects established. The first of these, of course, is related to the "ensemble" of values which constitutes the urban and regional climate. There are several conclusions from METROMEX which I feel are significant and probably will be upheld by any later investigations. First, GATz (1974) states that it has been demonstrated by the release at ground level, and later capture in rainwater, of specific chemical tracer materials, that particles which are injected into cloud systems by the city of St. Louis will probably be deposited at about the same distance downwind, $20-25 \mathrm{~km}$, as the area of relative maximum in precipitation totals is downwind from the city's industrial area. Thus, the distance and time relationships between the urban area and the area downwind thought to exhibit the effects of the city on precipitation are physically reasonable.

BRAHAM (1974) has analyzed the records obtained with a radar set to determine where echoes (indicating clouds containing large raindrops) are most likely to appear first in the St. Louis area under various sets of conditions. In the sample of cases which represent workdays (Monday through Friday) and weather conditions which produce cumulus clouds, echoes are most likely to appear for the first time in the area just downwind of St. Louis' industrial area. On weekends and holidays, with cumulus clouds in the sky, this area of high probability of first echoes disappears. This is strong evidence in favor of the hypothesis that industrial activities affect the processes of precipitation production and thereby the pattern of receipt of precipitation at the ground.

BraHAM also concludes, from measurements by aircraft of nuclei and of droplets near cloud bases, that urban areas produce an increase in the number of nuclei and droplets with a decrease in mean sizes and in the range of sizes of both. Since this kind of change in numbers and sizes would lead to a reduction in precipitation by cities if no other factors were operating, BRAHAM infers that the crucial component of the city's affect on rain production is probably the injection by the city of a relatively few but extraordinarily large nuclei - "giant nuclei" - into passing clouds, nuclei which are not detected by instruments currently in use.

AUER and DiRks (1974) confirm, with results based on measurements made with the aid of an aircraft, that a relatively warm and dry urban plume will probably be detected at heights of $300 \mathrm{~m}$ above the urban surface of St. Louis on typical clear, summer afternoons.

As part of the METROMEX programme, the Illinois State Water Survey maintains the world's largest network of closely spaced instruments for 
measuring precipitation, temperature, humidity, and wind speed and direction. It will probably be several years before the full value of these records has been realized, especially so for the measurements of precipitation. However, the network has already confirmed (JoNES and ScHICKEDANz 1974) the relative dryness of an urban area compared with its surroundings during midday, and the relative wetness of the urban area at night, in agreement with a variety of other studies.

\section{THE NORTH AMERICAN CONSENSUS IN 1975}

As noted previously, Oke (1974) has prepared an extremely valuable and well written review of research on urban climates completed during the period 1968-1973. In his review, OKE gives relatively more attention to the processes whereby urban areas modify the boundary layer, and therefore the local and regional climate, than to the changes in the values of the weather elements themselves. CHANGNON (1974) has offered a modern revision of LANDSBERG's original consensus (Table I) which attends to the changes in values of the elements. This appears here as Table $I I$.

\section{TABLE II}

Climatic changes produced by cities

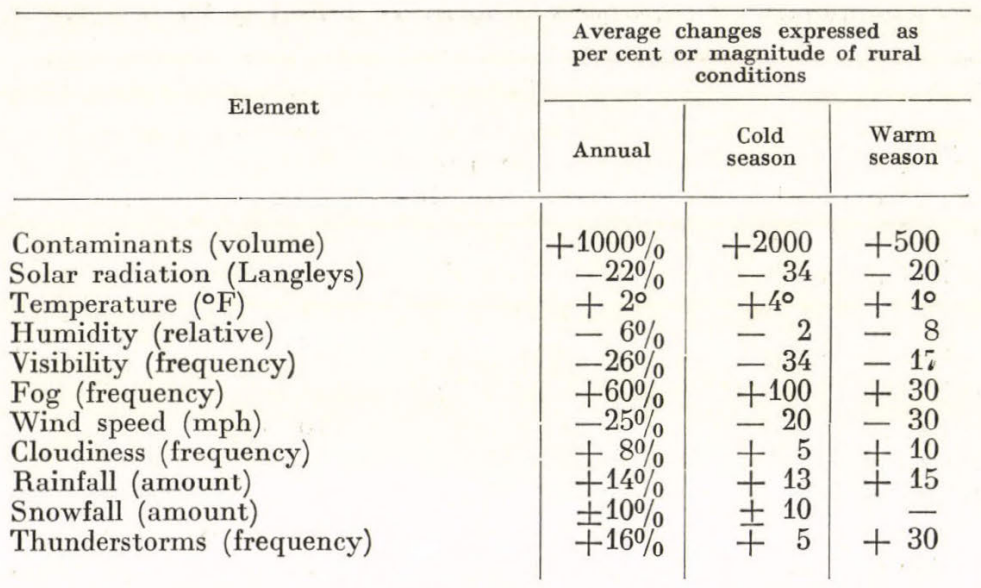

Note: Consensus held today (from CHANGNON, 1974).

With the aid of OKE's review, and taking CHANGNON's statement as a point of reference, I shall offer my own view of the consensus held by North American urban climatologists today.

Temperature. The urban heat island exists during most nights, for the reasons offered in the 1960 's, and with an intensity well described for a particular 
set of weather conditions by the expression given above due to Summers (1965). The average value of the intensity depends not only upon the amount of heat released by the city, but also upon the mixture of weather types exhibited by the region in which the city is located. Thus, the average values of intensities are seldom simply related to population alone, or to season alone, or to latitude alone, but to all of these and to the general level of heat-producing activity (i. e. degree of industrial development and intensity of energy use) within the city and its society. The values for $\Delta T$ given by CHANGNoN in Table II, therefore, include not only day and night differences but also differences from a great many weather conditions in a great many regional climates. The larger difference for the cold season doubtless reflect of additional heating for residences in those cities of the sample which are at higher latitudes.

Though the urban-rural differences are considerably less than at night, the warming effects of the city are felt during the day as well. However, the extra warmth appears above the street level if there are very tall buildings forming an urban canopy. The nocturnal urban boundary layer affected by heating extends upward to $300-500 \mathrm{~m}$ above the city, appearing as a "dome" under conditions of light regional winds and as a "plume" flowing downwind when regional winds are stronger. As a general rule, an urban effect on local temperature may be attributed to the nature of the urban surface within only about $500 \mathrm{~m}$ from the point of concern.

Precipitation. The present consensus holds that urban effects on precipitation totals are principally regional; that is, that the effects are felt outside the urban area and "downwind". CHANGNON's figure of about +15 per cent appears to mean that the urban area has a 15 per cent excess over the surrounding areas, but I believe he means to say that the totals in the center of a typical local maximum downwind are 15 per cent above those in the rural surroundings. In any case, the consensus on precipitation is the least firmly held of any for the major weather elements. Precipitation is transient, spatially non-uniform, and very sensitive to small changes in ambient conditions. All the same, the evidence is mounting that urban areas do have an effect on the precipitation processes. The separation of the modifications due to a city from those due to local features of the natural landscape, and those due to "random or natural spatial variability" has yet to be accomplished. The magnitudes and locations of the urban effects on precipitation may yet turn out to be different from what today's consensus holds. That there is an urban effect will probably be established by future research.

The consensus now holds that whatever increases a city may produce in precipitation totals, the increases come not as a result of changes in the low intensities, but rather in the high intensity categories. This is a change from the earlier consensus, and it follows from both a knowledge of the physics of clouds and from the fact that low intensity precipitation events usually contribute only a small fraction of a typical station's seasonal or annual total. Thus, an unlikely doubling of the total from "drizzly" or "showery" weather would be needed for a 10-15 per cent increase in the seasonal or annual precipitation total at a typical North American station, which suggests the earlier consensus was in error. 


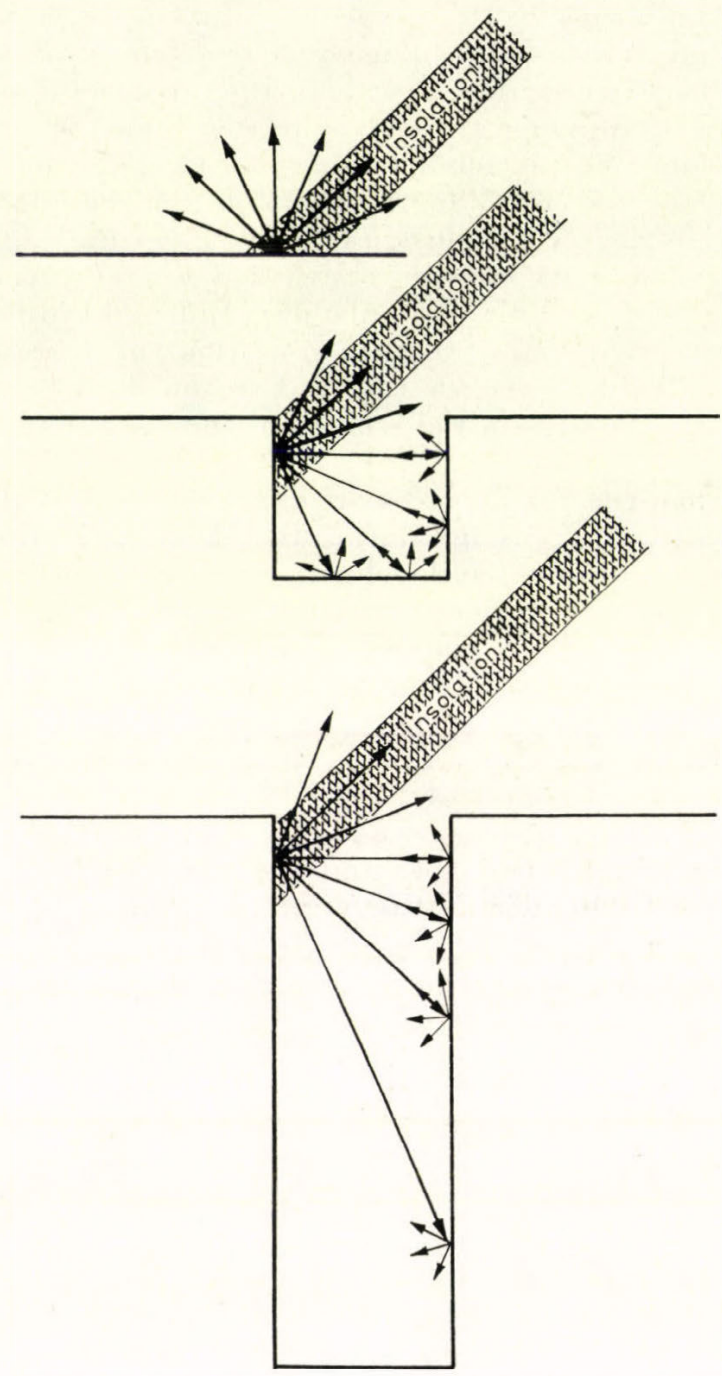

Fig. 4. Schematic interaction of solar radiation falling upon urban surfaces with different width/height ratios for the canyons between buildings (from LuDwIG, 1970)

Since the kind and magnitude of a city's effect on the precipitation process doubtless depends not only upon the form and use of the city itself, but also upon the particular weather conditions at the time and the mixture of weather conditions experienced within a season at a city, it is not surprising that no satisfactory generalization has been made concerning the season in which urban effects on precipitation totals are most evident. 
a

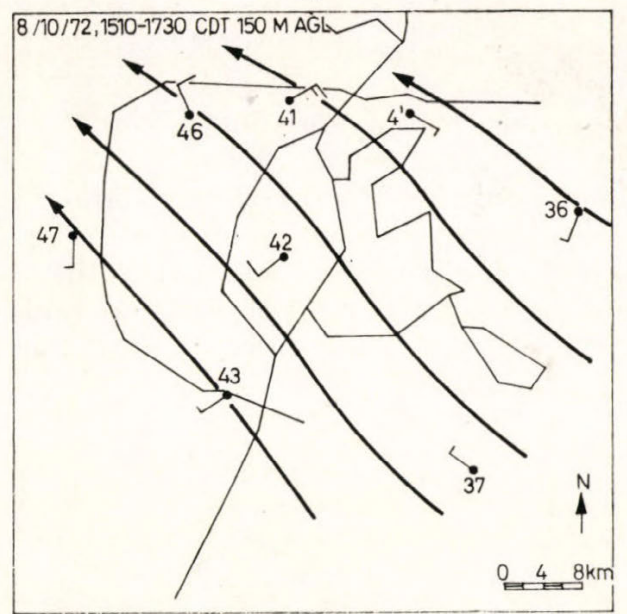

$b$

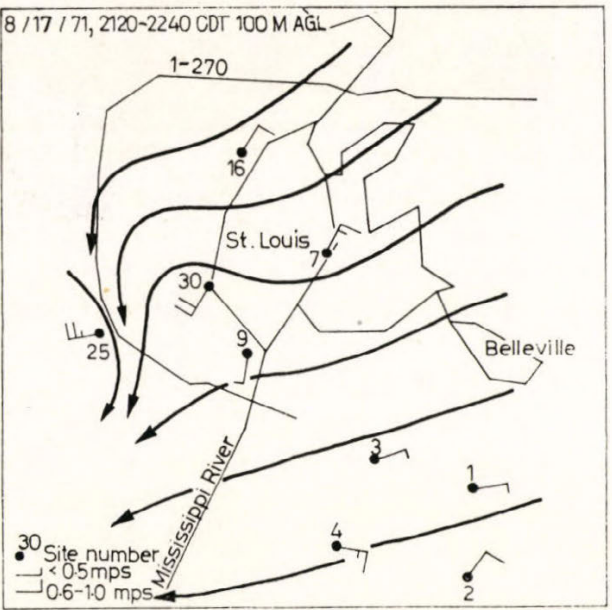

Fig. 5. Streamlines of low-level winds (100-150 m above the surface) above St. Louis

$\mathrm{a}=$ Midday with clear skies; $\mathrm{b}=$ at night with clear skies. Small wind arrows at individual stations show the "local" component of the wind flow probably as an urban effect (from ACKERMAN, 1974).

Wind. The consensus now recognized the oversimplification of the earlier conclusions about urban-rural differences in wind speed at ground level. It is now widely held that when moderate to strong winds are blowing in the region, the roughness of the city retards the flow, and speeds in the city center are reduced. When there are only light winds blowing in the region, it is likely that the general weather conditions prevent full exchange of momentum in rural areas, so that the source of momentum aloft is not being shared at the rural surface. Under these conditions, the thermal and mechanical turbulence produced by the city enhance the momentum exchange there and produce greater speeds at ground level in the city than in rural areas nearby.

Motion within the urban boundary layer (see definition above) is now held to be toroidal under conditions of light regional winds, and in the form of a plume when stronger regional winds are blowing. Under either condition, the upper surface of the boundary layer rises from the upwind edge of the city to the city center as the boundary layer deepens. Under generally clear skies, the top of the boundary layer over the city center undergoes one or several "pulses" during the course of a 24-hour period, as does the inward flow at the surface during the course of a calm and clear night (MUNN 1970).

At the surface, the flow into the city center induced urban heating will dominate under light regional winds, so that observations of wind will show the inflow directly. When regional winds are more vigorous, however, the inflow becomes a component added vectorially to the regional wind. Thereby, the observed winds exhibit an anticyclonic turning at the upwind edge of the city and a cyclonic turning on the downwind edge (see Figure 5 from AckerMAN 1974). 
Humidity. The consensus is still held that relative humidity is less in an urban area than in the environs, the reason being a combination of the higher temperatures in the city and a reduction there in the availability of water for evaporation. Measures of moisture content which are independent of air temperature (such as mixing ratio, dew point, or absolute humidity), however, show a deficit of moisture in the city by day and an excess by night under generally clear and dry weather. The daytime dryness is probably produced by the absence of evaporative surfaces and the presence of vigorous convective removal of any excess which may appear locally. The nocturnal wetness is probably due to the general cessation of evaporation in rural areas and the less vigorous removal of whatever moisture is being injected into the boundary layer in the urban areas.

\section{CRITIQUE AND SUMMARY}

My own critique of the present consensus and my recommendations for future research amount to the same comments. It appears certain that the urban climate, urban effects on local and regional climate, and the urban boundary layer (see definitions) are all very much dependent upon the particular city in question and the weather conditions of the moment. That is, generalities about urban effects will most profitably be drawn from individual case studies in which both the urban area and the weather conditions are "held constant" in a sample. The principal early writers (LANDSBERG 1956; MTTCHELL 1962; CHANDLER 1970) made this same point, but investigators have all too often ignored it. Classification of weather into "regional flow types" or "map types" was held in low repute by North American meteorologists in recent years, but some kind of classification, and some form of synoptic stratification of data, appears more and more to be essential in understanding the true nature of urban effects.

In addition to analysis of data stratified by city and by water type, recognition of the essential difference between "urban effects" and "urban-rural differences" (see definitions) requires the use of data from pre-urban time periods, or a reasonable approximation of such data. That is, recognition is needed among urban climatologists of the fact that urban-rural differences are really only expedient approximations of the true urban effects.

Much research is yet needed to understand the causal mechanisms which produce urban effects, and thus urban climates, but we might properly assign that research to urban meteorologists. The urban climatologist can probably, by judicious use of weather types and pre-urban data, establish the reality, the locations, the times, and the magnitudes of urban effects even without knowing fully the nature of the causal mechanisms.

\section{UTILITY OF FIRM KNOWLEDGE}

It is almost certain that the magnitudes of urban effects, and therefore the magnitudes of urban-rural contrasts, are seldom large enough to affect human behavior or decisions in any major way. Individuals do or do not live in 
this city or that for reasons almost wholly separate from urban effects on the climate, though their choices might bear some relationship to the climate of the region. Some writers have attempted to show that human behavior and physiological response under extreme weather conditions is different in a city from what it would be in the environs. I do not hold with this, however, and my hopes are to examine this matter in my own future research. Meanwhile, it is likely that urban climatologists have little of crucial value to students of human behavior.

The major utility of firm knowledge about urban effects, in my opinion, lies in the matter of understanding what effects man may have on the general atmospheric circulation patterns, which include the locations of storm tracks, the lengths of growing seasons, and the general sequences of weather conditions which make up regional climate. It has been suggested that the combined effects of a line of large cities, such as that from Washington, D. C. to Boston, might be the same as a low mountain range in the same location. The known responsiveness of the atmosphere's large-scale behavior to major terrain features makes the suggestion an important one. Urban designers have an increasing responsibility to understand the effects caused by what they design and build, especially so in the larger sense of the effects discussed here. Thus, my conclusion is that firm knowledge about urban effects on local and regional climates will probably have the greatest utility in matters of anticipating regional changes in large-scale weather behavior, and a lesser utility than generally believed in matters of the minute-to-minute comfort and wellbeing of individuals.

\section{REFERENCES}

A.M.S., 1972. Proceedings of the Conference on Urban Environment, Philadelphia, American Meteorological Society.

Ackerman, B. (1972): pp. 22-27.

Atwater, M. (1972): pp. 153-158.

Bornstein, R. (1972): pp. 89-94.

Bornstein, R. and Johnson, D. (1972): pp. 28-33.

Clarke, J. and Peterson, J. (1972): pp. 147-152.

Craig, C. and Lowry, W. (1972): pp. 159-164.

Mc'Elroy, J. (1972): pp. 185-190.

MunN, R. (1972): unpublished separate of address.

OKE, T. (1972): pp. 144-146.

Spangler, T. and Dirks, R. (1972): pp. 37-42.

Chandler, T. (1970): Selected Bibliography on Urban Climate. WMO Publication No. 276. TP. 155. World Meteorological Organization, Geneva.

Changnon, S. (1962): In: Air Over Cities. U.S. Public Health Service Technical Report A62-6, Washington, D. C., pp. 37-67.

Changnon, S. (1968): Bulletin American Meteor. Soc. 49, pp. 4-11. This paper prompted many comments and replies, which are listed here in chronological order.

Holmzman, B. and Thom, H. (1970): Bull. Amer. Meteor. Soc. 51, pp. 335-337. Reply by Changnon, pp. $337-342$.

Ogden, T. (1969): Journal Appl. Meteor. 8, pp. 585-591. Comment by Changnon (1971): J. Appl. Meteor. 10, pp. 165-168. Reply by Oanen, pp. 168.

Holtzman, B. (1971): Science 171, p. 847. Reply by Changnon (1972): Science 172, pp. 987-988. Reply by Hrdore (1972): Science 172, p. 988. 
Seidel, W. (1971): Bull. Amer. Meteor. Soc. 52, p. 105. Reply by Changnon, p. 105.

Hidore, J. (1971:) Bull. Amer. Meteor. Soc. 52, pp. 99-103. Comment by Holtzman: Bull. Amer. Meteor. Soc. 52,pp. 572-573. Reply by Hidore, pp. 573-574.

Ashry, W. and Fritss, H. (1972): Bull. Amer. Meteor. Soc. 53, pp. 246-251. Comment by F. Charton and Harmon, J. (1973): Bull. Amer. Meteor. Soc. 54, p. 26. Reply by AshBY and FritTs, pp. 26-27.

Changmon, S. (1974): Proceedings 4th Conference on Weather Modification, Fort Lauderdale. American Meteorological Society, pp. 347-352.

Duckworth, F. and Sandberg, J. (1954): Bull. Amer. Meteor. Soc. 35, pp. 198-207.

Howard, L. (1833): The climate of London deduced from meteorological observations made in the metropolis and at various places around it. London: J. and A. Arch, Cornhill; Longman and Co.

Huff, F. and Changnon, S. (1973): Bull. Amer. Meteor. Soc. 54, pp. 1220-1232.

Jones, D. and Schicke dANz, P. (1974): In: Interim Report of METROMEX Studies. F. HuFf (Ed.) Illinois State Water Survey, Urbana, Illinois. pp. 98-120.

Kratzer, A. (1937): Das Stadtklima. Braunschweig: Fr. Vieweg und Sohn.

LANDSBERg, H. (1956): In: Man's Role in Changing the Face of the Earth. Chicago: University of Chicago Press, pp. 584-603.

Landsberg, H. (1962): In: Air Over Cities, U.S. Public Health Service Technical Report A62-5. Washington, D. C., pp. 1-22.

Lowry, W. (1967): Scientific American, 217, pp. 15-23.

Lowry, W. (1970): Bull. Amer. Meteor. Soc. 55, pp. 87-88. This introduction was followed by technical articles written by scientists of the METROMEX programme. ACKerman, B. (1974): pp. 93-95.

AUer, A. and Dirks, R. (1974): pp. 106-110.

BraHAM, R. (1974): pp. 100-106.

GATZ, D. (1974): pp. 92-93.

Mitcheld, J. (1953): Journal of Meteorology 10, pp. 244-261.

Mrtcheld, J. (1962): In: Air Over Cities. U.S. Public Health Service Technical Report A62-5. Washington, D. C., pp. 131-145.

Oke, T. (1974): Review of Urban Climatology 1968-1973. Technical Note No. 134. World Meteorological Organization, Geneva.

Peterson, J. (1969): The climate of Cities: A Survey of Recent Research. U.S. Public Health Service Publication No. AP-59. Washington, D. C.

W.M.O. (1970): Proceedings of the Symposium on Urban Climates and Building Climatology, Brussels. Technical Note No. 108. World Meteorological Organization, Geneva.

Chandler, T. (1970): pp. 1-14.

Clarke, J. and McElroy, J. (1970): pp. 108-112.

LUDWIG, F. (1970): pp. 80-107.

MunN, R. (1970): pp. 15-39.

Oke, T. and HanNeLL, F. (1970): pp. 113-126. 


\section{THE PROBLEMS OF AIR QUALITY IN BUDAPEST}

By

FERENC PROBÁLD

\section{THE CAUSES OF AIR POLLUTION}

The first network for the systematic measurement of air pollution in Budapest was established in the late fifties. The first results of the processed data have shown that as far as the amount of important indicator pollutants, i.e. sulphur dioxide and smoke is concerned, the capital of Hungary ranks amongst the cities with the most polluted air in the world.

The reasons for this serious situation are as follows:

a) The primacy of Budapest in the urban hierarchy of Hungary, due to its favourable geographical position and to the peculiar characteristics of the historical (economic and political) development. Nowadays there are 2 million inhabitants in Budapest and they make up almost 20 per cent of the total population of Hungary. Even this remarkable territorial concentration of population is surpassed by the concentration of industry. In 1930 nearly 60 per cent of industrial production of Hungary came from Budapest, and even now one third of national industry is still concentrated in the capital. The share of Budapest has been diminishing at an increased rate since the early sixties only. This is a result of the measures taken in the frame of planned regional development policy. It was considered the most important task to develop the industry of the provinces by setting up factories especially in the highest category regional centres of the country, while limiting industrial investment in Budapest mostly for the reconstruction of existing plants.

b) The characteristics of the territorial structure of the city. The basic features of the urban pattern of Budapest have developed since the second half of the 19th century in the period of rapid capitalistic development. An industrial belt surrounds the city core as a semi-circle. Amongst the industrial plants of this belt low quality residential areas for workers have been established. The inner residential belt, surrounding downtown, is overcrowded with buildings; in some districts the population density exceeds 20,000 persons/ $\mathrm{sq} . \mathrm{km}$. The narrow streets exert a highly negative effect by hindering the dilution of emissions produced by traffic.

c) Physical geographical (orographical and meteorological) factors. On the west, Budapest is bordered by the Buda Hills partly covered with forests, partly built-up in a rather loose way. Consequently, the prevailing NW-N winds bring relatively clean air above the city core. During the winter half-year, however, winds blow from the SE sector with almost equal frequency. These latter winds are, unfortunately, of low speed and laminar character thus transporting pollutants from the industrial belt to the city core, where they accumulate in the foreground of the Buda Hills. The frequent and long-lasting inversions of the winter half-year also contribute to increased air pollution. 
d) The high specific emission from industry, domestic heating and traffic. After the First World War both in industrial and in public consumption of the high-quality Silesian coal was replaced by Hungarian brown coals high ash content and 2 to 4.5 per cent sulphur content. A significant increase in the share of hydrocarbons in the energy economy took place only from the sixties onward. Not only the low quality fuel but also the obsolete domestic and industrial heating installations have been factors increasing the amount of pollutants in the air. Emissions caused by domestic heating and industry have roughly an equal role in polluting the atmosphere of Budapest, the first one being more important in the core of the city, the latter in the industrial belt. Significant local sources of pollution are the railway stations although steam locomotives are now being replaced by modern diesel and electric engines.

Up to recent times traffic emissions have been rather low in the air pollution of Budapest. However, the past decade has brought an immense change. The stock of vehicles in Budapest increased between 1960 and 1970 from 15,000 to 83,000 and by 1976 was close to 200,000. Due to the composition of the vehicle stock according to type, age and technical condition, the specific emission exceeds the world level by an estimated 40 or 50 per cent. An especially disadvantageous factor is the high share of cars with two-stroke engines because they release especially large amounts of hydrocarbons. Due to these facts the polluting effect of automobile traffic is much higher than justifiable on the basis of the number of vehicles.

\section{THE MAIN RESULTS OF AIR POLLUTION MEASUREMENTS}

The first network for measuring air pollution in Budapest, consisting of 56 stations, was put into operation by the National Institute for Public Health in 1958. The measurement programme included determination of the amount of deposited dust, and relative figures of total sulphur content obtained by Liesegang's method. The sulphur dioxide concentration was measured in the form of eventual samplings only. The concentration of other pollutants was also measured occasionally. Since 1963 the network has been operated by the Public Health and Epidemiological Service (KÖJÁL), continuing the measurement programme of the previous years till 1968. Since 1968 the number of permanent stations of KÖJÁL has been decreased to 34. On the other hand, at eight points the systematic measurement of the concentration of the most important pollutants has been started. In 1970 in the downtown area the first monitoring station equipped with registrating instruments was put into operation. On the basis of the measurements the following can be assessed regarding the air quality problem in Budapest:

a) The most serious problem is still the high sulphur dioxide pollution of the air (Table I). By envisaging the areal distribution (Fig. 1) it can be stated that prominent maximum values can be found in the densely populated inner city and in some parts of the industrial belt. In the winter half-year the sulphur dioxide concentration exceeds the permitted emmission standard 


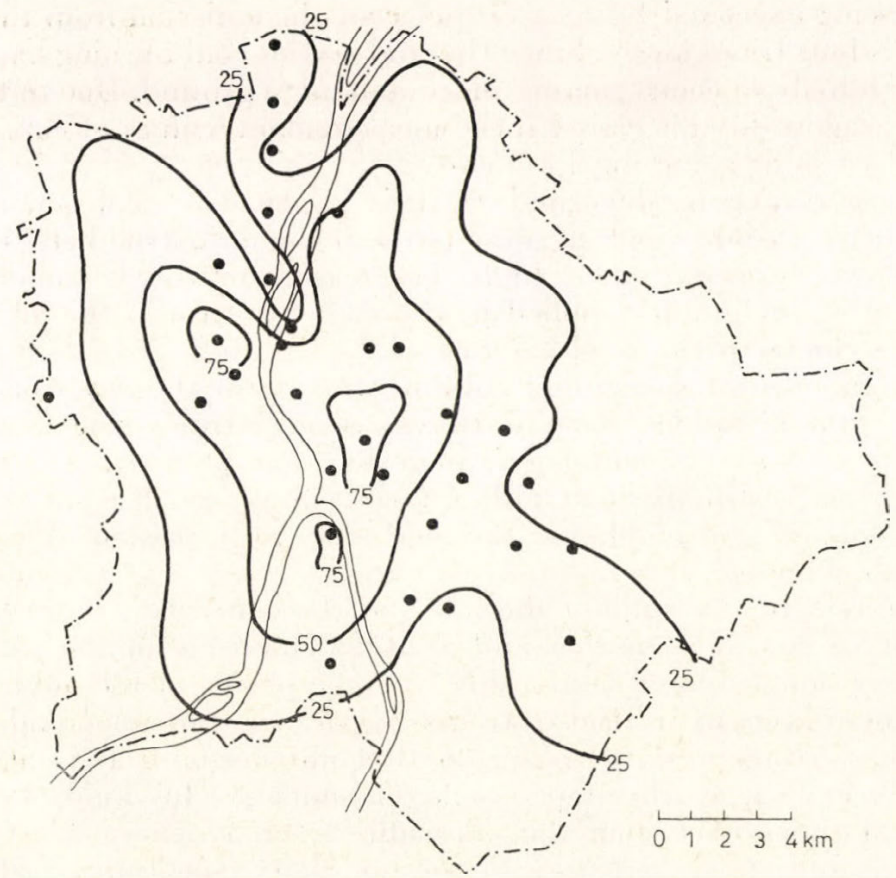

Fig. 1. The areal distribution of sulphur dioxide pollution in Budapest, 1975. (Popovics et al. 1976)

The figures refer to the number of days when ambient air quality standard for protected areas was exceeded

\section{TABLE I}

The concentration of sulphur dioxide $(A)$ and nitrogen oxides $(B)$ in the ambient air $\left(\mathrm{mg} / \mathrm{m}^{3}\right)$. Average of 8 measuring stations, Budapest

\begin{tabular}{|c|c|c|c|c|c|c|c|c|}
\hline & \multicolumn{2}{|c|}{ Winter half-year } & \multicolumn{2}{|c|}{ Summer half-year } & \multicolumn{2}{|c|}{ Annual average } & \multicolumn{2}{|c|}{$\begin{array}{l}\text { Permitted daily average } \\
\text { in protected areas }\end{array}$} \\
\hline & $A$ & $B$ & $A$ & $B$ & $A$ & $B$ & $A$ & B \\
\hline $\begin{array}{l}1972 \\
1973\end{array}$ & $\begin{array}{l}0.54 \\
0.48\end{array}$ & $\begin{array}{l}0.15 \\
0 \cdot 14\end{array}$ & $\begin{array}{l}0.14 \\
0.18\end{array}$ & $\begin{array}{l}0.12 \\
0.11\end{array}$ & $\begin{array}{l}0 \cdot 34 \\
0 \cdot 33\end{array}$ & $\begin{array}{l}0.14 \\
0.12\end{array}$ & $\begin{array}{l}0.15 \\
0.15\end{array}$ & $\begin{array}{l}0 \cdot 05 \\
0 \cdot 05\end{array}$ \\
\hline
\end{tabular}

everywhere in Budapest, and reaches a multiple of this figure in the inner city. Regional pollution of industrial origin covers the whole of NE-Transdabia, and the local pollution of Budapest is superposed on this.

The main cause of sulphur dioxide pollution is the high amount of emission from industrial and domestic heating installations due to the high sulphur content of the fuels. In the area of Budapest during the early sixties about 250,000 tons of sulphur dioxide were released annually into the atmosphere, 
this figure being exceeded by only 50 per cent the emission from the London area which is four times larger. Since the mid-sixties coal burning has begun to decrease with hydrocarbons gaining more and more ground. Due to the slowly decreasing sulphur dioxide emission the measurement values of emission have also started to show some improvement.

b) The importance of deposited dust is relatively small and it exceeds the air quality standards only in some parts of the industrial belt. The smoke pollution, however, is extremely high. The reason for this lies mainly in the obsolete heating techniques applied in the city, but also in the high amount emitted by vehicles with diesel engines.

The accumulation of smoke and sulphur dioxide in the atmosphere of the capital has caused sudden daily darkness several times since 1958. These pollutants are the primary causes of damage due to air pollution which amounts in Budapest to an estimated 820 million forints annually. The most important items are: damage to buildings, damage due to corrosion of metals and direct health damage.

c) In contrast to the sulphur dioxide pollution affecting extensive areas, the amount of gaseous chlorine and that of chlorides in the ambient air exhibits exceptionally high values only at some places in the industrial belt. Pollutants produced by traffic (nitrogen oxides, carbon monoxide, various hydrocarbons) attain a level similar to that observed in large cities of the world which have a much larger stock of vehicles. This kind of pollution, often several times exceeding the allowable level, is characteristic of the arterial roads and traffic junctions of the inner city (see Table I). Traffic exhaust gases affect an ever increasing area, with concentrations reaching higher and higher peaks.

\section{TOWARD EFFECTIVE AIR POLLUTION CONTROL}

After learning the facts concerning the deterioration of air quality as early as the end of the fifties an increasing number of measures have been taken in order to improve conditions and the term "quality of air" has become the subject of ever more complex legal regulation. The steps taken against air pollution have received the general approval of public opinion. Since the early sixties a keen interest has been taken in this matter not only by the professional journals but also by the daily press as far as the results of the struggle for protecting our environment are concerned.

It was in 1959 that the first decision about the tasks of air pollution control was made by the Council of Budapest. In 1965 the Air Pollution Control Commission of Budapest was established. The activity of this commission included the classification of factories in Budapest according to their environmental effects, and the marking of industrial plants either to be developed or considered to be removed to the country. On the basis of a proposal presented by the Air Pollution Control Commission of Budapest to the Council of Budapest, at the end of 1968, the establishment of new coal burning installations was prohibited and the modernization of heating installations in the houses of the inner city was started. 
The measures taken in Budapest and in other towns proved that it was necessary to regulate air quality on a nationwide scale and on the basis of uniform principles. In 1968 the Ministry of Building and Urban Development was entrusted by the Economic Commission of the government with the management of this work. Within the frames of the ministry the National Air Pollution Control Commission was established with advisory work and reports by experts as its main functions. The basic principles of air pollution control have been stated by this commission. A nationwide legal regulation for protecting air quality was achieved by issuing the executive order No. 1/1973. Guidelines for further work have been laid down by the Environmental Protection Act approved by Parliament in 1976.

In a cabinet order of 1973 standards have been set as to the allowable concentrations of the most important pollutants of the air, with different figures applicable for highly protected, protected and other (industrial) areas. Compliance with this air quality standard is a long-term task which requires the stepwise curtailment of emissions. Factories and plants are encouraged by governmental support and preferential credits to make investments resulting in a decrease of pollution, and imposed penalties also tend to influence them in the right direction. The penalties are to be used by the National Air Pollution Control Fund mainly for supporting the most important investments aimed at the abatement of emissions. Remarkable steps have been taken to organize the manufacture of equipments and measuring instruments used in protecting air quality, thus establishing the industrial background of an air pollution control programme. Finally, it must be mentioned that for the period 1971-1985, 121 million forints have been provided by the national long-term plan of scientific research for research projects serving the protection of our atmospheric environment, as part of the special programme for establishing the principles of the most favourable macro- and micro-scale human environment. In the course of the last decade the following practical steps have been taken in order to control air pollution in Budapest:

a) A basic change in the composition of fuel consumption in Budapest. This means that most factories have introduced natural gas heating and the share of apartments equipped with modern district heating or with gas heating has steadily increased. Though the decline in the reliance on coal was mainly justified by economic considerations, the modernization of energy consumption at the same time also exerted a favourable effect on air quality (Table II).

b) Removal of several industrial plants which have particularly disturbed their environment. In the frame of this programme nearly 200 production

\section{TABLE II}

Changes in the composition of fuel consumption in Budapest $\left(10^{12} \mathrm{kcal}\right)$

\begin{tabular}{c|r|r|r|r|r|r}
\hline Year & Gas & Liquid fuel & Coke & Wood & $\begin{array}{c}\text { Coal and } \\
\text { coal-briquette }\end{array}$ & Total \\
\hline \begin{tabular}{c|r|r|r|r}
1965 \\
1980
\end{tabular} & $\begin{array}{r}3 \cdot 40 \\
\text { (plan) }\end{array}$ & $\begin{array}{r}6 \cdot 92 \\
12 \cdot 00\end{array}$ & $\begin{array}{r}1 \cdot 46 \\
1 \cdot 66\end{array}$ & $\begin{array}{r}0 \cdot 97 \\
0 \cdot 97\end{array}$ & $\begin{array}{r}21 \cdot 25 \\
3 \cdot 37\end{array}$ & $\begin{array}{r}34 \cdot 00 \\
45 \cdot 00\end{array}$ \\
\end{tabular}

17 Enyedi: Urban 
units - most of them with small numbers of workers - have been relocated in the countryside. New locations have been assigned also to some of the larger factories, e. g. to the exceptionally foul smelling animal protein processing plant.

c) Making a smokeless zone in the inner city. This programme covers the fifth district and part of the thirteenth district of Budapest where the complete abandonment of heating with coal, coke and low quality fuel oil with a sulphur content higher than 1 per cent has been foreseen. Modernization of heating installations in apartments, using public funds, has taken place at a rate slower than anticipated, but even so, the project will be completed by the late seventies.

d) Automobile traffic has been banned from Margaret Island and control of smoke from buses and lorries has been initiated. These are the first steps toward the decrease of air pollution caused by road traffic. The new Traffic Code which came into force in 1976 has for the first time set standards for emission by passenger cars. However, it will obviously require several years to establish the conditions necessary for the enforcement of these regulations.

\section{SOME PROBLEMS OF GEOGRAPHICAL RESEARCH CONCERNING AIR POLLUTION}

It is obvious that complex research accomplished by geography to promote the matter of environmental protection cannot avoid the study of air pollution, because the change in the composition of the atmospheric air has an effect also on the processes taking place in other geospheres. It is especially important to consider air pollution in the case of research serving the needs of city planning.

In the next part two problem spheres of our own research in Budapest will shortly be outlined to illustrate the various topics to be studied by geography when it has to make a contribution to improving the atmospheric environment of the cities.

a) The formation of the characteristic urban mezo-climate is based on the local modification of the energy balance of the surface. This modification is due not only to the changed character of the built-up area but also to the pollution of the air. As a result of measurements and research carried out in Budapest, every important detail of climatic energy budget deviations between the densely built up, heavily polluted inner city and the natural surrounding of the capital have been cleared up (РRовÁLD 1971, 1974). Due to the shorter sunshine duration and the higher turbidity of the city air the total amount of global radiation reaching the surface of the city is decreased by about 8.4 per cent on an annual average. Difference is greatest in January with the city's radiation loss attaining 25.7 per cent. On the other hand, no increase of incoming long-wave radiation could be proved. This is evident of the fact that aerosol pollution may at the most increase the greenhouse-effect of the atmosphere above the city only to a very small extent, thus being an insignificant factor in the development of the urban heat island phenomenon. 


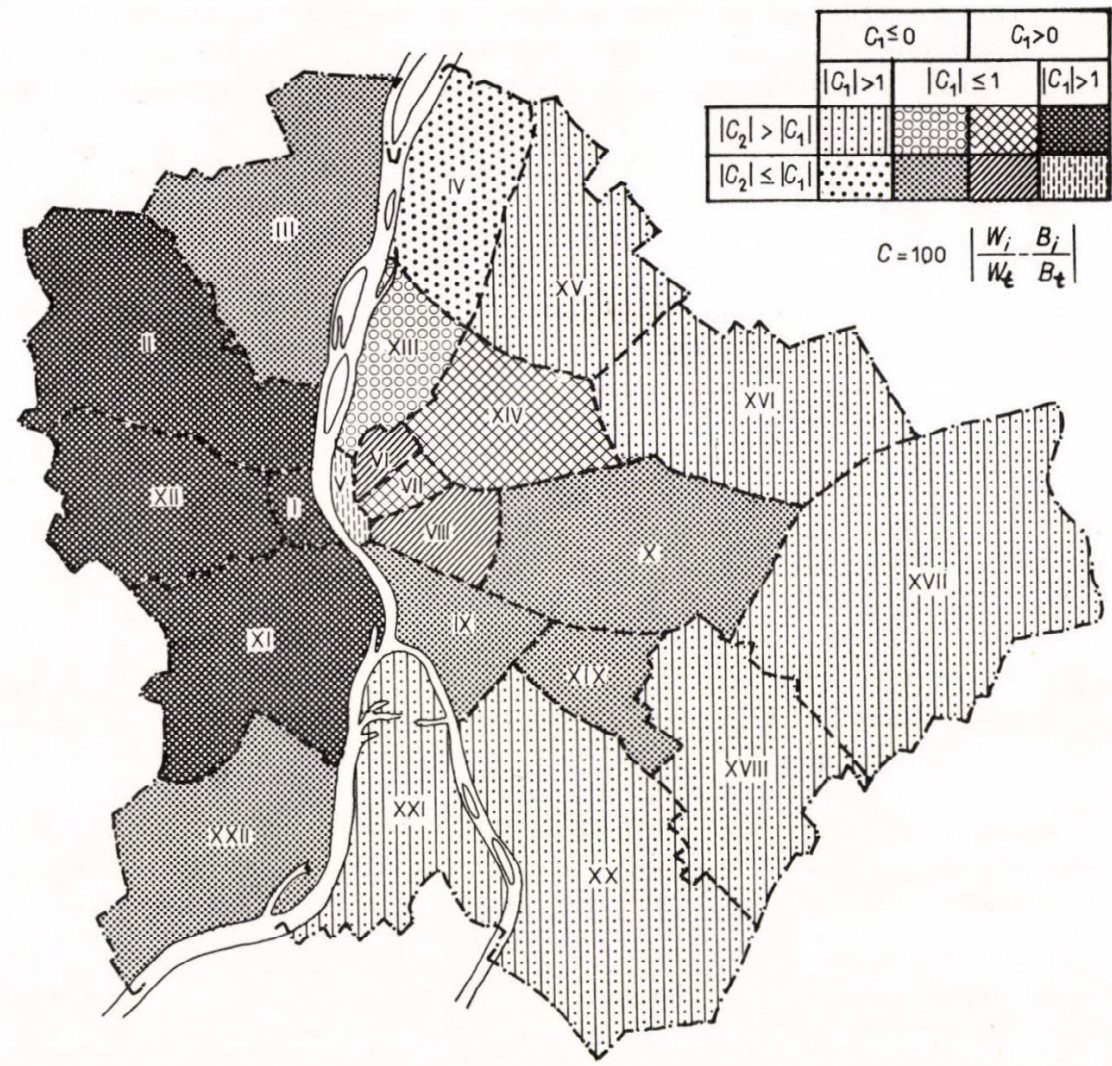

Fig. 2. The residential segregation of white-collar workers in Budapest

$W_{i}$ and $B_{i}=$ number of inhabitants of district $i$ belonging to the white-collar and bluecollar groups respectively. $-W_{t}$ and $B_{t}=$ total number of people belonging to those groups in Budapest

Index 1 refers to the year 1960, index 2 to 1970. Signs on the left from the main vertical axis of the legend indicate an above-normal share of blue-collar residents, while the right side group of signs marks a higher than average share of white-collar residents. The main horizontal axis of the legend separates signs of an increasing contribution to the city-wide index of segregation (above) from signs of a decreasing contribution to that index (below)

Air pollution today is mainly an effective climatic factor in cities only, but in the near future it may exert an influence on the climate of macroregions and even of the whole Earth. Therefore research into urban climate may provide a valuable basis also for predicting world-wide anthropogenic modifications of climate. On the other hand, a knowledge of the energy balance of the city is one of the basic research tasks providing us with the information necessary for the possible improvement of the urban bioclimate by means of city planning.

b) Air pollution is an unfavourable factor from the point of view of the population, evoking some kind of response from the people concerned. In this 
way even the structure of land use in the cities may spontaneously be influenced. On the basis of incentives by the Commission on Man and Environment of the IGU the types of human response to air pollution have been examined in several cities including also Budapest by using uniform questionnaires developed for the purpose of international comparison (Квомм et al. 1973).

Only one item from the result of the survey will be mentioned here: in answering the question about the favourable and unfavourable characteristics of their residential neighbourhood, 52 per cent of the respondents spontaneously mentioned the quality of the air. In the answers, distance from the city centre and traffic conditions occurred with about equal frequency. This means that the population knows and evaluates the importance of the atmospheric environment of its residence. This is manifested also in the fact that in Budapest the depressive effect of a highly polluted atmospheric environment on basic land values can be stated (ProBÁLD 1974).

Finally, it will be mentioned that in one of our most recent studies the residential segregation of various social strata in Budapest has been investigated and it was found that the highest concentration of white-collar residences can be observed in districts with the double advantage of being close to the city centre and having a healthy atmospheric environment (Fig. 2). This proves that white-collar employees have an increased demand for a high quality environment and probably also somewhat better financial conditions to satisfy that need (ProBáLD 1975).

It is obvious that several socio-geographical research tasks are connected with the problem of air pollution and more intensive work in this field of research would provide very useful information for urban planning.

\section{REFERENCES}

Kromm, D. E., Probáld, F. and Wald, G. (1973): An International Comparison of Response to Air Pollution. J. of Environmental Management, 1. pp. 363-375.

Popovics, M., Szepesi, D. and Várkonyi, T. (1976): The Quality of Ambient Air in some Hungarian Cities. Időjárás, 80, pp. 326-331.

Probáld, F. (1971): The Energy Balance as the Basis of the Urban Climate of Budapest. Annales Uniø. Sc. Eötøös, Sectio Geographica, VII. pp. 51-68.

Probáld, F. (1974): Air Pollution and the Urban Climate of Budapest. In: Pécsi, M.-Probáld, F. (ed.): Man and Environment. Studies in Geography in Hungary, 11, pp. 191-196.

Probáld, F. (1975): The Problem of Residential Segregation in Budapest. Annales Univ. Sc. Eötıös, Sectio Geographica, IX. pp. 103-112. 
Part four

RURAL TRANSFORMATION 



\section{NONMETROPOLITAN CHANGE IN URBAN AMERICA- TEXAS, A UNITED STATES CASE STUDY}

By

KINGSLEY E. HAYNES, DIANA DEARE and DENNIS HARNER

\section{INTRODUCTION}

The United States became an urban dominated society during the first half of the twentieth century, however, it is only since World War II that this urbanization become predominantly metropolitan in character. Just as the process of urbanization was paralleled by a reorganization of the economic and occupational structure of the nation from an agriculturally dominant society in the 1800's to an industrial society of the early 1900's so the process of metropolitanization has been accompanied by a shift in economic and occupational structure from industrialization to post-industrialization. The latter is characterized by the rise of the service sector, most notably the sophisticated quarternary components typified by information management complex administrative systems and the delivery of human services in both the private and public sectors.

This process of change is reflected throughout the nation but has been compressed in time in those regions that are the most recent arrivals to the postindustrial period. Texas is such a region. Still a major agricultural state with a rapidly declining rural and small town urban population it has been ushered into the twentieth century with the drive for new technology, the spin-offs of the space programme, and the requirements and capital accumulation of an energy supplier in a high energy society.

The metropolitan population of Texas, that is, population in those areas classified in 1970 as standard metropolitan statistical areas (SMSA's) with a residential populous in excess of 50,000, showed a rate of increase of 23.7 per cent between 1960 and 1970. This is significantly higher than that for the state as a whole, or for that of the nonmetropolitan, or non-SMSA, population (1.3 per cent). In fact, of the entire population increase between 1960 and 1970,98 per cent occurred in SMSA's. That such a large proportion of the state' population increase was concentrated in metropolitan areas simply reflect the continuation of a historic trend toward urbanization or, more specifically, metropolitanization. By 1970 nearly 74 per cent of the population of Texas resided in standard metropolitan statistical areas, as compared with about 70 per cent in 1960, and 62 per cent in 1950. A fact clearly indicated by these figures is that the nonmetropolitan population of Texas, that is, the population outside the SMSA's, has been steadily decreasing as a proportion of the total population of Texas.

The metropolitanization of Texas is even more striking when trends is SMSA's by size are examined. Of the total metropolitan population increase of 1,577,898 during the 1960-1970 decade, about 85 per cent $(1,339,965)$ occurred in SMSA's of 500,000 or more (Dallas, Fort Worth, Houston, and 
San Antonio SMSA's). These four SMSA's now include slightly over 46 per cent of the population of Texas, whereas in 1960 they included only 40 per cent, and in 1950 only 34 per cent. Finally, the rate of growth of this largestsize group during the most recent decade was 35 per cent, a growth rate twice as large as the rate for the state.

Counties suffering population losses between 1960 and 1970 are predominant in Texas. For all practical purposes, the entire Panhandle of the state is characterized by population decline, save only a few counties on the western and northern boundaries. Furthermore, the population-decrease region includes at least one half of the remaining land mass of the state. In absolute terms 146 of the 254 counties of Texas (or better than 57 per cent) lost population during the most recent decade. This fact, together with evidence noting a positive growth rate of 16.9 per cent for the state as a whole, indicates clearly that the 1960's may best be characterized as a period of metropolitanization; the population of Texas has continued to become even more concentrated in a very few large urban agglomerations.

\section{PURPOSE}

It is within this context of metropolitanization that the authors have investigated two elements of nonmetropolitan change. The first element of change in nonmetropolitan urban places deals with the distributional character of growth and decline. Part I, therefore, attempts to identify the differential character among nonmetropolitan urban places that leads to subsequent growth and/or decline. The second element of nonmetropolitan change empirically examines the degree to which spread and/or backwash effects of a metropolitan growth pole impact the nonmetropolitan hinterland. This comprises Part II of the present study.

\section{PART I}

\section{URBAN NONMETROPOLITAN POPULATION CHANGE}

This portion of our paper focuses upon the changes in population size which have occurred among nonmetropolitan incorporated places (NMI) in Texas over the 1960-1970 decade. There were 519 such places in 1960 and they contained a total population of 1,649,262. By 1970 the number had increased to 572 and the population to 1,793,186, overall increases of ten per cent and nearly nine per cent respectively (DEARE and Poston 1973). In spite of this overall increase, however, individual places showed striking variations in population change: 20 per cent of the total number experienced losses of 10 per cent or more, 24 per cent had losses of less than 10 per cent, 22 per cent had gains of less than 10 per cent, and 33 per cent gained by 10 per cent or more. 


\section{METHODOLOGY}

The first technique employed is a factor analysis of variables which characterize places in 1960, for the purpose of discovering common structural features among places. The towns are then grouped into three categories - growing, stable, and declining - depending upon population changes from 1960 to 1970. These groups are subjected to a multiple discriminant analysis, using the derived factor scores as input, to determine first, if there are significant structural differences among them, and second, the nature of these differences.

\section{STRUCTURAL FEATURES OF NONMETROPOLITAN PLACES}

The units of analysis employed in this study are nonmetropolitan incorporated (NMI) places of Texas with a 1960 population of 2500 or more. "Nonmetropolitan" refers to locations outside the 41 counties designated as SMSA counties in $1970 .{ }^{1}$ The size restriction is necessary due to the limited amount of data available for places with population under 2500. There were 169 nonmetropolitan incorporated (NMI) places greater than or equal to 2500 in 1960.

DeAre and Poston (1973) examining nonmetropolitan urban places in Texas for the decades 1950-60 and 1960-70 found that the size of the nonmetropolitan place at the beginning of the period was positively related to growth performance during the forthcoming decade. Furthermore, they discovered that growth performance of nonmetropolitan places was negatively influenced if the distance to the nearest metropolitan center city was greater than 50 miles. These relationships, however, were weak and declined in importance from the 1950 's to the 1960's. Although descriptively functional it is clear that these are findings that have only minor policy implications.

For each of the 169 places, 39 demographic, social, housing, labor force, and economic characteristics were collected from census materials. The variables were selected in an attempt to provide a comprehensive analysis of community features. The relation of employment and economic base characteristics to urban growth is emphasized in economic base theory, and these variables have been employed in similar studies by HoDge (1971) and KING (1967). Demographic and social characteristics of the population have also been frequently included (Commission on Rural Poverty, 1968). KING (1967) found that demographic, social, and housing characteristics were the most critical in discriminating between growth categories in the Canadian provinces of Quebec and Ontario. Since there is no consensus as to which variables are

${ }^{1}$ In 1970 Texas had 24 SMSA's, which included 41 counties. An SMSA, or standard metropolitan statistical area, as recognized by the Bureau of the Census, is "a county or group of contiguous counties which contains at least one city of 50,000 inhabitants or more, or 'twin cities' with a combined population of at least 50,000. In addition to the county, or counties, containing such a city or cities, contiguous counties are included in an SMSA if, according to certain criteria, they are socially and economically integrated with the central city." U.S. Bureau of the Census, U.S. Census of Population: 1970, Number of Inhabitants, Final Report PC (1)-A45 Texas, vii. 


\section{APPENDIX 1}

PART I.

\section{URBAN NONMETROPOLITAN POPULATION CHANGE}

\section{TABLE I}

Variables included in the factor analysis of NMI places of Texas

Name and description
Demographic characteristics:
1. Population size. The total population of each urban place in 1960
2. Nonwhite population. The per cent of the total population which is

2. Nonwhite population. The per cent of the total population which is nonwhite

3. Foreign or mixed parentage. The per cent of the total population which is of foreign or mixed parentage

4. Foreign born. The per cent of the total population which is foreign born

5. Productive population. The per cent of the population which is 18 to 65 years old

6. Retirement population. The per cent of the population which is 65 years old and over

7. Sex ratio. The number of males per 100 females in the population

8. Fertility ratio. The number of children under 5 years old per 1000 women 15 to 49 years old

9. Area per population. The number of square miles per 1000 population

Social characteristics :

10. Education. The per cent of persons 25 years old and over with 4 years of high school or more education

11. Married males. The per cent of males 14 years old and over who are married

12. Married females. The per cent of females 14 years old and over who are married

13. Poverty. The per cent of families having incomes of less than $\$ 3,000$

14. Well-to-do. The per cent of families having incomes of $\$ 10,000$ or more

Housing characteristics :

15. Group quarters. The per cent of the total population living in group quarters

16. Population per household. The average number of occupants per household

17. Home ownership. The per cent of all housing units which are owneroccupied

18. Vacancy. The per cent of all housing units which are available vacant

19. Soundness. The percent of all housing units which are sound

20. Plumbing. The percent of all housing units which have all plumbing facilities

21. Aged housing. The per cent of all housing units which were built before 1950

22. Home value. Median value of owner-occupied units

23. Rental cost. The median rent of renter-occupied units

POPSIZ

NONWHT

FORMIX

FORBRN

PRDPOP

RETPOP

SEXRAT

FRTRAT

ARAPOP

EDUCAT

MARMLS

MARFMS

POVRTY

WELLDO

GRP

POPHLD

HOMOWN

VANCY

SNDNSS

PLMBNG

AGDHSG

HMEVAL

RENTAL 


\section{\begin{tabular}{l} 
Name and description \\
\hline Labor force characteristics: \\
24. Unemployment. The per cent of the civilian labor force which is un- \\
employed
\end{tabular}}

25. Nonworker-to-worker ratio. The ratio of nonworkers to workers in the population

26. Employed males. The per cent of males 14 years old and over in the labor force

27. Employed females. The per cent of females 14 years old and over the labor force

28. White-collar workers. The per cent of total employed included in the combined census categories of "Professional, Technical, and Kindred Workers", "Managers, Officials, and Proprietors, Exc. Farm", "Clerical and Kindred Workers", and "Sales Workers"

29. Male white-collar workers. The per cent of the total employed males included in the "white-collar" census categories

30. Female white-collar workers. The per cent of the total employed females included in the "white-collar" census categories

\section{Economic base characteristics:}

31. Manufacturing. The per cent of employed persons in manufacturing industries

32. Agriculture. The per cent of employed persons in agriculture

33. Public administration. The per cent of employed persons in public administration

34. Retail establishments. The number of retail establishments per capita

35. Retail sales. The per capita retail sales

36. Retail employees. The per cent of total employed persons which are full-time retail employees

37. Services establishments. The number of services establishments per capita

38. Services receipts. The capita services receipts

39. Services employees. The per cent of total employed persons which are full-time services employees
Code

UNEMPL

NONWKR

EMPMLS

EMPFMS

WTCLWK

MLWTCL

FMWTCL

MNFACT

AGRCLT

PUBADM

RTLEST

RTLSLS

RTLEMP

SRVEST

SRVRCT

SRVEMP

Sources:

U.S. Bureau of the Census. County and City Data Book, 1962 (A Statistical Abstract Supplement). U.S. Government Printing Office, Washington, D.C., 1962: Appendix A-2.

U.S. Bureau of the Census. U.S. Census of Business : 1958. Selected Services BC 58-SA 43, Texas. U.S. Government Printing Office, Washington, D.C., 1960: Table 102.

U.S. Bureau of the Census. U.S. Census of Business: 1958 . Retail Trade, BC 58-RA 43, Texas. U.S. Government Printing Office, Washington, D.C., 1960: Table 102.

U.S. Bureau of the Census. U.S. Census of Housing, 1960. Volume I, States and Small Areas. Part 8: Texas. U.S. Government Printing Office, Washington, D.C., 1943: Tables 18, 20, 21, 22, 23, 24, 25, and 26.

U.S.Bureau of the Census. U.S. Census of Population: 1960. General Population Characteristics, Texas. Final Report PC(1)-45B. U.S. Government Printing Office, Washington, D. C., 1961: Tables 13, 20 , and 22.

U.S. Bureau of the Census. U.S. Census of Population: 1960. General Social and Economic Characteristics Texas. Final Report PC(1)-45C. U.S. Government Printing Office, Washington, D.C., 1962: Tables 32, 33, 34, $72,73,75,76$, and 81 .

most relevant, and since factor analysis encourages an exploration of all possibilities, all these categories of variables were included in the present analysis. These variables are displayed in Table I (Appendix 1). All variables with the exception of those pertaining to retail trade and services refer to 
characteristics of the places in 1960; variables 34 through 39 refer to 1958 conditions.

A factor analysis was performed on the 169 observations and 39 variables. Varimax rotation yielded eight factors with eigenvalues greater than unity, which together accounted for 74.9 per cent of the total variance among places (see Table II-Appendix 1).

\section{TABLE II}

Percentages of total variance explained by rotated factors

\begin{tabular}{l|c}
\hline \multicolumn{1}{c|}{ Factor } & Variance explained \\
\hline 1 Wealth & $20 \cdot 8326$ \\
2 Ethnicity & $15 \cdot 5176$ \\
3 Institutional & $8 \cdot 8288$ \\
4 Professional & $8 \cdot 6261$ \\
5 Agricultural & $5 \cdot 7674$ \\
6 Familial Dependence & $6 \cdot 0630$ \\
7 Occupancy & $4 \cdot 1710$ \\
8 Low Retail & $5 \cdot 1368$ \\
\hline Total & $74 \cdot 9433$
\end{tabular}

The first factor appears to be a wealth dimension; variables which have high positive associations with this factor include various indicators of highquality housing and high income. The variables which load highest on the second factor pertain to demographic and ethnic aspects of towns. A town which scores highly on this dimension has a relatively small foreign population, low population per household, and low levels of fertility and unemployment. On the other hand, towns which score highly negative on this dimension are of high foreign population content, high population per household, high fertility levels and unemployment. Given the particular geographic location of the study area, it appears that this factor might be an indicator which divides the Texas nonmetropolitan population into the wealthier "Anglo" rural areas to the north and poor Mexican and Mexican-American nonmetropolitan areas to the south. Towns dominated by the latter populations are located near the United States-Mexico border and therefore having a relatively high percentage of Mexicans and U.S. citizens of Mexican descent.

The third factor is institutional in nature: towns scoring high on this dimension are characterized by high percentages of the population living in group quarters and low percentages of married males and males in the labor force. Towns containing a college or university, military establishment, nursing home, medical facility, or penal institution fit this description. ${ }^{2}$

2 Nine places scored higher than 1,000 on this factor. Eight are the sites of universities, seven of which had university enrollments in 1960 which accounted for more than twelve per cent of their total populations. The ninth place is the site of a state home for girls. 
TABLE III

Primary loading structure after rotation

\begin{tabular}{|c|c|c|}
\hline Variables & & Factors \\
\hline $\begin{array}{l}\text { RENTAL } \\
\text { POVRTY } \\
\text { HMEVAL } \\
\text { MARFMS } \\
\text { AGDHSG } \\
\text { EDUCAT } \\
\text { PLMBNG } \\
\text { SNDNSS } \\
\text { RETPOP } \\
\text { WELLDO } \\
\text { SEXRAT } \\
\text { FMWTCL }\end{array}$ & $\begin{array}{r}.8426 \\
-.8348 \\
.8289 \\
.8102 \\
-.7958 \\
.7515 \\
.7201 \\
.6276 \\
-.6270 \\
.6201 \\
.5764 \\
.5353\end{array}$ & $\begin{array}{c}1 \\
\text { Wealth }\end{array}$ \\
\hline $\begin{array}{l}\text { FORBRN } \\
\text { POPHLD } \\
\text { FORMIX } \\
\text { UNEMPL } \\
\text { FRTRAT } \\
\text { SRVEST } \\
\text { RTLEST } \\
\text { ARAPOP }\end{array}$ & $\begin{array}{r}-.8513 \\
-.8264 \\
-.8113 \\
-.6800 \\
-.6600 \\
.6225 \\
.5347 \\
.3869\end{array}$ & $\stackrel{2}{\text { Ethnicity }}$ \\
\hline $\begin{array}{l}\text { GRPQTS } \\
\text { MARMLS } \\
\text { EMPMLS } \\
\text { PRDPOP }\end{array}$ & $\begin{array}{r}.9285 \\
-.7257 \\
-.6966 \\
.6621\end{array}$ & $\begin{array}{l}3 \\
\text { Institutional }\end{array}$ \\
\hline $\begin{array}{l}\text { WTCLWK } \\
\text { MLWTCL } \\
\text { SRVRCT } \\
\text { SRVEMP }\end{array}$ & $\begin{array}{l}\cdot 7658 \\
\cdot 7473 \\
\cdot 5296 \\
.4438\end{array}$ & $\begin{array}{l}4 \\
\text { Professional }\end{array}$ \\
\hline $\begin{array}{l}\text { MNFACT } \\
\text { NONWHT } \\
\text { POPSIZ } \\
\text { AGRCLT }\end{array}$ & $\begin{array}{r}-.7429 \\
-.5797 \\
-.5300 \\
.5263\end{array}$ & $\begin{array}{l}\stackrel{5}{\text { Agricultural }} \\
\text { Agris }\end{array}$ \\
\hline $\begin{array}{l}\text { EMPFMS } \\
\text { PUBADM } \\
\text { NONWKR }\end{array}$ & $\begin{array}{r}-7077 \\
.6445 \\
.5320\end{array}$ & Familial dependence \\
\hline $\begin{array}{l}\text { VACNCY } \\
\text { HOMOWN }\end{array}$ & $\begin{array}{r}.7885 \\
-.5339\end{array}$ & $\begin{array}{c}7 \\
\text { Occupancy }\end{array}$ \\
\hline $\begin{array}{l}\text { RTLEMP } \\
\text { RTLSLS }\end{array}$ & $\begin{array}{l}-.7730 \\
-.5635\end{array}$ & $\begin{array}{c}8 \\
\text { Low Retail }\end{array}$ \\
\hline
\end{tabular}

A high percentage of white-collar occupations and services characterize the fourth factor; this can be labeled a professional dimension. The fifth factor is an agricultural dimension. Towns representative of this dimension are small with a white population and low levels of manufacturing employment but high levels of agricultural employment. 
The sixth factor is characterized by a low per cent of working females and a corresponding high nonworker-to-worker ratio and may be considered a dimension of familiar dependence. The seventh dimension is strictly concerned with housing occupancy characteristics and consists of a high per cent of available housing and a corresponding low per cent of owner-occupied housing. The eighth and final dimension is an indicator of the importance of retailing in city structure. A place with a high positive score on this dimension is relatively deficient in retailing activity (Table III-Appendix 1).

\section{CHARACTERISTICS OF GROWING AND DECLINING PLACES}

A multiple discriminant analysis (CASETTI 1961) was employed to determine if growing and declining places have differing structural features and how these differences, if any, can be characterized. Multiple discriminant analysis extracts orthogonal factors, called linear discriminant functions or LDF's, which display differences among pre-determined groups. The LDF's are the linear combinations of the orthogonalized variables which best separate the groups. The criterion for separation is the maximization of the ratio of betweento-within-group variance. In effect, discriminatory analysis assumes that the observations are already in legitimate groups and then answers the questions: (1) Are the groups really different? and (2) What are the main discriminators between the groups, i. e., what variables really differentiate the groups?

The first step was to divide the 169 NMI places into groups on the basis of their growth performances from 1960 to 1970. Two sets of percentage rates of population change were employed in the classification. The first set was computed from the 1960 and 1970 population counts reported in the Census of Population. These rates, however, are deficient because they do not take into account the effects of annexation. Annexation was very prevalent in Texas: 142 of the 169 places increased in land area due to annexation over the decade.

The effects of annexation vary and cannot be specifically determined using census data. However, if this first rate is an increase, and there was annexation during the period, the increase may actually include people who resided on the annexed land prior to 1960 as well as migrants into the area after 1960 . In the same way, a reported rate of decrease may have been in part offset by the annexation of land which contained people who had resided there since before 1960 .

Using the U.S. Census annexation report (1971) information a second set of percentage rates was computed which only considered changes in the population within the 1960 area from 1960 to $1970 .^{3}$ This method of computation tends to have opposite effects from the first. Here, a reported rate of increase may be too conservative, for it does not include migrants to the area during

\footnotetext{
3 Taking annexation into account had the effect of deflating reported rates of population increase and inflating rates of population increase and inflating rates of population decrease, because part of the growth reflected by the first set of rates may have been due to annexation and part of the decline may have been offset due to annexation.
} 
the period who settled in the annexed area either before or after annexation. The rate of decrease, on the other hand, may be overstated, as it will include residents who moved to the added area either before or after annexation as well as those who left the town and went to other places.

Each place was classified as growing, declining, or stable according to both rates of population change. A place which had one positive rate of change or 10 per cent of higher combined with a positive rate of any size was put in the growing group. A place with one negative rate of change of at least 10 per cent combined with another negative rate was put in the declining group. The remaining places, which had no rate of change of 10 per cent or higher or had two rates with opposite signs, were classified as stable.

Ten per cent was chosen as the degree of change which should be considered significant for the following reason. It was felt that the critical rate should relate to some norm for nonmetropolitan growth. The rate of population growth for all NMI places in the United States from 1960 to 1970 was 11.29 per cent, (FuguitT 1971, p. 452) and the rate for all NMI places in Texas over the same period was 8.71 per cent (DeARe and Poston 1973, p. 11). Since there is no compelling reason for selecting one of these rates rather than the other, the average of the two - 10.00 per cent - was chosen.

The three groups, comprised of 45 growing, 80 stable, and 44 declining places, and the factor scores from the preceding factor analysis were used as orthogonal input to a multiple discriminant analysis. The analysis yielded two discriminant functions whose discriminant powers are shown in Table $\mathrm{IV}$

\section{TABLE IV}

Percentage of total variance explained by linear discriminant functions

\begin{tabular}{c|c}
\hline \multicolumn{1}{c|}{ LDF'S } & Variance explained \\
\hline 1 & 53.13 \\
2 & 46.87 \\
\hline Total & $100 \cdot 00$
\end{tabular}

(Appendix 1). Overall group differentiation was tested with an $F$ ratio and the Wilk's Lambda criterion and was significant. The significance of each discriminant function was examined by a Chi-square test. The absence of significant discrimination implies that the groups overlap and cannot be distinguished with respect to a particular function. Both discriminant functions were significant, with probabilities of change occurrence of .0006 and .0005 (see Table V-Appendix 1).

Figure 1 is a two-dimensional plot scaled in terms of the discriminant scores, which indicates the location of the groups along both discriminant functions. The first function mainly separates the growing group from the stable and declining groups; the growing group has a high positive score while the other two groups have negative scores. The second function separates 


\section{TABLe V}

Significance tests for discriminant analysis

Overall group differentiation:

Wilk's Lambda $=\cdot 700$

D. F. $=16$ and 318

$F$-Ratio $=3 \cdot 884$

$$
P=\cdot 0000
$$

LDF 1:

Chi-Square $=30 \cdot 857$

D. F. $=9$

$$
P=\cdot 0006
$$

LDF 2:

Chi-Square $=27 \cdot 510$

D. F. $=7$

$P=\cdot 0005$

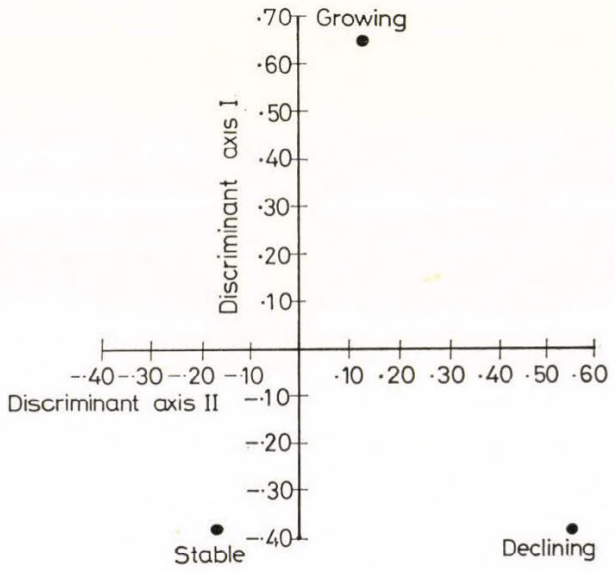

Fig. 1. Group centroids and discriminant functions

all three groups: the declining group has a high positive score, the growing group has a low positive score, and the stable group scores negatively.

$A$ description of the discriminant functions in terms of the original eight dimensions is provided by the matrix of correlations between the two (see Table VI-Appendix 1). This matrix is analyzed much the same as the matrix of loadings in factor analysis. The variables influence an LDF in proportion to their loadings within the LDF, and in the sense indicated by the sign of the loading. Therefore, (a) variables with small (near zero) loadings do not affect the LDF, (b) variables with high positive loadings tend to be proportional to the LDF, and (c) variables with high negative loadings will tend to be inversely proportional to the LDF. The relationship measured by loadings between variables and the LDF's is the basis for interpretation of the LDF's.

The first function is determined, in order of importance, by professional, institutional, and retail dimensions. Since this function separates the growing group from the others, the most important structural difference between growing and other places is the presence of higher levels of professional, in- 


\section{TABLE VI}

Correlation between variables (factors) and discriminant functions

\begin{tabular}{l|r|r}
\hline \multicolumn{1}{c|}{ Factors } & LDF 1 & \multicolumn{1}{c}{ LDF 2 } \\
\hline Wealth & .1684 & .8849 \\
Ethnicity & -.2911 & $-1 \cdot 1191$ \\
Institutional & .3841 & -.1452 \\
Professional & .6837 & .0829 \\
Agricultural & -.2293 & .3001 \\
Familial dependence & .2621 & -.1613 \\
Occupancy & -.0514 & -.0502 \\
Low retail & -.3697 & .2326
\end{tabular}

stitutional, and retailing activities (since "Low Retail" is inversely related to the LDF) in the former.

The second function appears to be mainly determined by wealth and agricultural dimensions. This function separates all three groups; therefore, declining places are characterized by a greater degree of wealth and agricultural activity, and stable places are inversely associated with both wealth and agriculture.

The results appear reasonable except for the relation of wealth with the growing and declining groups. The wealth dimension is composed of highquality housing and high income characteristics, and it is not immediately apparent why such conditions are more likely to favor subsequent decline than subsequent growth.

One issue of course is that in such strong economic circumstance high levels of capital investment continues to take place resulting in labor savings. Hence job opportunities continue to shrink. However, this answer is not wholly satisfying. The 44 declining places were mapped in order to investigate this paradox. 33 were located in the Panhandle and West Texas areas. This geographic concentration of decline suggests that factors other than those considered in the analysis had a strong effect upon decline. Two highly likely factors, both of which have become increasingly important in the recent decade, are the sinking water table in the Panhandle and the decline (through the 1960's) of petroleum-related employment in the Permian Basin (West Texas). ${ }^{4}$

Furthermore, the majority of declining towns with high positive scores on the wealth factor are concentrated in the Permian Basin. This suggests an explanation for the association between wealth and subsequent decline. Places

\footnotetext{
${ }^{4}$ Statistics concerning the decline in petroleum-related employment in this area during the 1960's are available in "Quarterly Reports of Covered Employment", which are prepared by the Texas Employment Commission, and in the U.S. Bureau of Census' Census of Mineral Industries, Vol. II, Area Statistics for 1958, 1963 and 1967. Production data in the Mineral Yearbook, published by the U.S. Department of Interior, Bureau of Mines, indicates that the drop in employment was not due to a decline in production. However, there was a great decrease in exploratory drilling as well as increasing efficiency and technological improvements, which may account for the substantial decline in employment.
} 
in which the petroleum industry was an important contributor to the local economy would likely have had a relatively "wealthy" population in 1960 . The decline in employment in this industry experienced between 1960 and 1970 would force people to migrate to places with more economic opportunity.

The objective of this study was to determine the structural features of places which are associated with growth and decline. The analysis indicates that there were significant differences in 1960 between towns which grew and those which declined from 1960 to 1970. The presence in a town of a high level of professional (white-collar and services) employment and activity, and/or an institution, and/or a high level of retail employment and activity favored subsequent population increase. The opposite conditions set the stage for little change or population decline.

\section{POLICY IMPLICATIONS}

Population policies, or planned attempts to influence future population trends, require as a basis an understanding of the current situation. The results of this study may help provide such a basis. It is evident that any attempt at planning must give recognition to all areas of the state. The two types of regions, metropolitan and nonmetropolitan, are complementary, and recognition of this interrelatedness has led to realization that the urban problems of congestion and over-crowding can be viewed in part as a result of the inability of non-SMSA areas to attract and retain population. Indeed, the stimulation and encouragement of growth in rural areas has become a popular policy in recent population distribution proposals, with the goal of alleviating not only problems of low income and high unemployment in rural areas but also the diseconomies of congestion in metropolitan areas.

Insights into structural features associated with growth could suggest appropriate strategies. For example, the finding that the institutional dimension is a significant discriminator between growing and other places offers a potential course of action, since institutional activity is directly amenable to governmental intervention.

Due to the unique distribution in the decline of nonmetropolitan incorporated places in the western portion of the state - the Texas Panhandle and Permian Basin Regions - it was decided to investigate these areas in more detail. Specifically it was decided to examine the spatial relationships between 10 center in the region and its nonmetropolitan hinterland. After a brief literature review and the establishment of the policy setting the authors investigate the transmission of economic growth impulses from the metropolitan center to its regional hinterland. 


\section{THE IMPACT OF METROPOLITAN GROWTH ON THE NONMETROPOLITAN HINTERLAND}

\section{INTRODUCTION}

Spatial imbalances in economic welfare are readily discernible in the United States. In addition to rural-urban and suburban-central city imbalances, there are strong regional imbalances (MoRRILL and WoHLENBERG 1971). Certain regions of the United States are referred to as "lagging" since the economic welfare of the population, taken as an aggregate, is below a national standard with respect to employment and/or income. The Federal Government took positive measures to alleviate some of these imbalances at the regional level in the mid-1960's. These measures came in the form of the Appalachian Regional Development Act (ARDA) and the Public Works and Economic Development Act (PWEDA).

The ARDA was enacted in 1965 in recognition of the high unemployment and low income which characterized so much of the population in the Appalachian region from Mississippi to New York State. In the same year, the PWEDA was passed to deal with the same problems in five other lagging regions (New England, Upper Great Lakes, Four Corners, Ozarks, and Coastal Plains). Both of these Acts recognized the importance of urban places located in and near these lagging areas as vehicles for economic development. The ARDA implicitly recognized urban growth centers as important, but it did not require their use in aby development schemes, while the PWEDA explicitly required the use of economic development centers (HANSEN 1972). The purpose of this paper is to test the efficiency of urban growth centers in a selected region as effective transmitters of economic growth impulses.

\section{URBAN "GROWTH CENTERS"}

Urban growth center literature is most often traced to PERRoux, who popularized the concept of polarized economic growth (PERROUx 1970). His discussion of economic growth focused on interindustry linkages. Perroux's "key" industry is the one that induces growth to both directly linked industries and to the regional economy. This key industry can be thought of as one row of an input-output matrix with important linkages to many other industries and strong induced effects in the regional economy. Polarized growth in the Perrouxian context is an example of industrial dominance with no explicit attention to geographical space (HANSEN 1970).

While PERROUX was concerned with economic growth in industrialized countries, Myrdal (1957) and Hirschman (1958) both developed essentially the same notion of polarized growth for less developed countries characterized by regional inequalities in economic welfare. All three of these development theories share a belief in unbalanced growth and, while the terminology varies, all would have one sector of the economy growing more rapidly than the 
others. This growth sector would induce growth to the other sectors via its dominance over them. MYRDAL and HiRschman put unbalanced growth into a regional setting by discussing the effects of rapid economic expansion, usually industrial, in a more advanced region upon the lagging region. Admitting both positive and negative effects on the lagging region, they postulated an increase in economic welfare in that region in the long run.

According to Hirschman's terminology (HIRschman 1958, pp. 183-190), the positive effects are referred to as "trickle-down" effects while the negatives as "polarization" effects. Trickle-down effects would primarily be 1) purchases by the advanced region from the lagging region, 2) empioyment in the advanced region of unemployed people from the lagging reglon, and 3) the diffusion of greater technology to the lagging region. Polarization effects would be 1) migration of skilled labor to the advanced region, 2) industrial depression in the lagging region due to inefficiency in that region relative to the advanced region, and 3 ) the flow of capital from the lagging region to the advanced region. "Spread" and "backwash" are Myrdal's equivalents to trickle-down and polarization, respectively.

A major problem associated with the above literature on economic growth, particularly with PERRoux's work, concerns the geographic location of those sectors or industries responsible for growth. BOUDEVILLE is often given credit for advancing Perroux's concept of space by taking into account the location of the key industry (HANSEN 1971).

BOUDEVILLE recognized three types of regions: homogeneous, polarized, and planning. He saw the polarized region as "a heterogeneous space whose different parts complement and support one another and where these parts have more exchange of goods and services with a dominant intraregional urban center, or pole, than with neighboring regions" (HANSEN 1971, p. 17). He perceived the polarized region, not the homogeneous or planning, as useful with respect to Perroux's concept of polarized economic growth. Boudeville concluded that Perroux's growth poles were realy urban places with agglomerations of key industries (Thomas 1972, p. 57). So, rather than focus on the individual industries, Boudeville suggested attention be given to the urban places where these industries locate.

After Boudeville's work, which began in the late 1950's a greater recognition of the spatial aspects of economic growth, and, in particular, a greater recognition of the role of cities came about. Because neither the term growth pole nor development pole in the earlier literature necessarily implied an urban location, the term "growth center" evolved in order to emphasize the importance of cities. DARWENT (1969, p. 11) defined the growth center as a location, usually a city, in geographical space. No mention was made of the industries located at that center. However, the growth pole literature, with its emphasis on the mechanisms of industrial dominance, had led to the growth center notion because industries tend to locate in urban places. Cost reductions due to location factors, i.e., external economies of agglomeration, are available in cities, and once this is recognized, regional growth schemes naturally focus on the urban places in a region and near it (HANSEN 1974, pp. 62-73).

A universally agreed upon definition of a growth center is not available, nor is it forthcoming. Varying definitions are needed depending upon the 
requirements of the research problem. One broad definition which incorporated space and polarized growth would define a growth center as an urban place from which positive spread effects diffuse to the surrounding hinterland (after NICHOLs 1969, p. 193). PWEDA was enacted with this definition in mind (Hansen 1973, p. 16).

\section{EVALUATION OF GROWTH CENTER PERFORMANCE}

One of the major problems in growth center strategies has been the question of whether or not growth centers actually perform to the above expectations. Before addressing this problem we should distinguish between natural and planned growth centers. Growth centers are natural or spontaneous when there is little or no direct government intervention (ALONSO and MEDRICH 1972, p. 230). Natural growth centers are "the result of spatial concentration arising from a high marginal productivity of capital and agglomerative economics", and they "achieve a self-sustaining rate of growth over a period of time and are the source of diffusion of growth impulses to neighboring urban centers" (SEMPLE et. al. 1972, p. 572). In contrast is the planned growth center which involves direct government intervention. This paper is concerned with natural growth center performance so that planned growth center performance might be anticipated.

The question of performance is an especially difficult one when there are different measures of success. Migration from a lagging region might be a spread effect to one analyst and a polarization effect to the local residents. Most empirical evaluations have focused on the employment situation in the hinterland of a growth center. As HANSEN wrote (1974, p. 213), "the notion of spread effects is most commonly associated with the induced generation of 'secondary jobs' in hinterland counties". The studies reviewed by HaNsen (1974, pp. 213-214) did not find that the spread effects were great and that they were sometimes less than the backwash effects that often accompany growth centers. However, these studies emphasized job creation and interindustry relations as the measures of spread effects. This study will focus on the aggregate economic welfare of the population in the hinterland since an increase in rural employment does not necessarily mean improved economic welfare (HANSEN 1973, p. 15).

Using a measure of economic welfare, this study will examine the spread effects associated with a natural growth center. In accordance with growth center theory, it is hypothesized that the growth center will induce spread effects to its hinterland and that the magnitude of these spread effects will decrease with distance from the growth center.

\section{METHODOLOGY}

CASETti and SEmple (1968) developed a trend surface routine which separates spatial trends in a stepwise manner and identifies peaks and depressions in the spatial distribution of a variable. The routine finds the point from which the reciprocals of the distance to all other locations in the region are maximally 
correlated with the value of the variable at those other locations. Once the point has been found, the routine calculates the regional trend in the distribution of the variable and the residual values which the regional trend does not account for. The procedure is "applicable when empirical observations or theoretical considerations suggest a given spatial variable tends to have values the higher (or lower), the closer they are to given locations" (CASETTI and Semple 1968, p. 5).

After extraction of the regional trend associated with the most important growth point, the residuals can be subjected to the same trend surface routine so that other growth points can be identified. Borrowing from terminology used by the Appalachian Regional Commission, a region might have a "regional center" which would be identified first, and it might have "primary centers", dominated by the regional center, which would be identified through analysis of the residuals (HANSEN 1972, p. 270).

The studies which have used this trend surface routine have focused on finding unpredicted growth points. CASETTI and SEMPLE (1968) found the centers of positive and negative population change in Ontario, Canada, and they concluded that their trend surface routine was well suited for the identification of growth centers. SEMPLE et. al (1972) used the same technique to find urban growth centers in Sao Paulo, Brazil.

This study will use the trend surface technique somewhat differently to test for polarized growth. The natural growth center will be predetermined rather than sought. The technique will determine the point from which the growth impulses radiate; that point and the natural growth center for the region should coincide since growth impulses should theoretically decrease with distance from the growth center.

\section{GROWTH CENTERS IN THE HIGH PLAINS DF TEXAS}

Alonso and MEDrich (1972) studied the incidence of spontaneous (natural) growth centers in the United States in the 20th century. Only seven cities have been able to meet their growth requirements over the entire period: Miami, Tampa-St. Petersburg, Houston, Lubbock, Tucson, Phoenix, and Los Angeles (Alonso and MedrICH 1972, p. 243). Lubbock has been selected for investigation primarily because it is the smallest in population of the spontaneous growth center, and because it would appear that its growth has been the least affected by amenity or climatic factors.

Lubbock's dominance of the High Plains region (Figure 2) of Texas [as delineated by the State of Texas for its input-output simulation of the state's economy (GRUBB 1973, p. 7)] will be tested. This large region was selected for several reasons, including the fact that it is the center of a planning region created by the state. Since much regional policy is executed by states, the authors feel their boundaries should be used for analysis when possible. It is felt that Lubbock is the dominant city in this region, especially in light of its performance as a spontaneous growth center.

Other important centers in the region are Amarillo, Midland, and Odessa. Amarillo is at the same level as Lubbock in Berry's urban hierarchy; both 


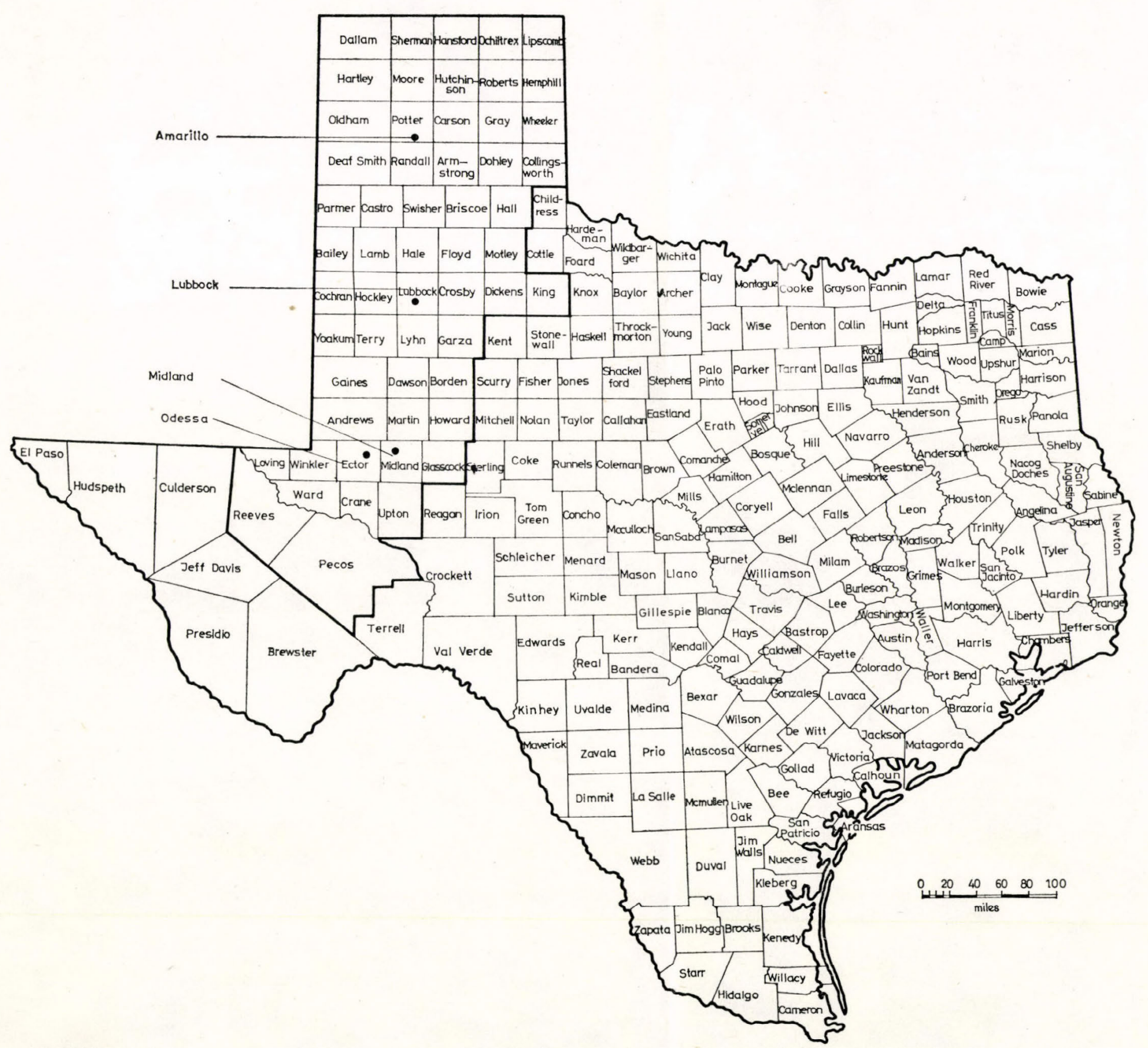

Fig. 2. The High Plains Region of the Texas Input-Output Model (with SMSAs located) Source: H. W. Grubb: The Structure of the Texas Economy. Vol. 1, Austin, Texas: Office of the Governor, 1973, p. 7. 

APPENDIX 2

\section{PART II}

\section{THE IMPACT OF METROPOLITAN GROWTH}

\section{ON THE NOMMETROPOLITAN HINTERLAND}

TABLE I

Per cent change in median family income for High Plains counties

\begin{tabular}{|c|c|c|c|c|c|}
\hline County & 50 to 60 & 60 to 70 & County & 50 to 60 & 60 to 70 \\
\hline Andrews & 57 & 48 & King & - & - \\
\hline Armstrong & - & 78 & Lamb & 56 & 50 \\
\hline Bailey & 46 & 55 & Lipscomb & 81 & 120 \\
\hline Bordon & - & 51 & Loving & - & - \\
\hline Briscoe & 23 & 71 & Lubbock & 65 & 52 \\
\hline Carson & 56 & 69 & Lynn & 42 & 46 \\
\hline Castro & 00 & 56 & Martin & 100 & 16 \\
\hline Cochran & 45 & 32 & Midland & 70 & 51 \\
\hline Collingsworth & 57 & 57 & Moore & 61 & 45 \\
\hline Crane & 53 & 31 & Motley & 35 & 59 \\
\hline Crosby & 48 & 77 & Ochiltree & 47 & 55 \\
\hline Dallam & 47 & 50 & Oldham & - & 60 \\
\hline Dawson & 61 & 48 & Parmer & 43 & 47 \\
\hline Deaf Smith & 47 & 69 & Pecos & 85 & 44 \\
\hline Dickens & 19 & 91 & Rotter & 51 & 51 \\
\hline Donley & 41 & 73 & Randall & 70 & 59 \\
\hline Ector & 56 & 51 & Reeves & 47 & 55 \\
\hline Floyd & 67 & 56 & Roberts & - & 82 \\
\hline Gaines & 56 & 50 & Sherman & 31 & 47 \\
\hline Garza & 78 & 30 & Swisher & 52 & 54 \\
\hline Glass cock & - & 19 & Terry & 69 & 56 \\
\hline Gray & 67 & 49 & Upton & 39 & 47 \\
\hline Hale & 52 & 53 & Ward & 70 & 47 \\
\hline Hall & 56 & 90 & Wheeler & 71 & 51 \\
\hline Hansford & 63 & 43 & Winkler & 55 & 41 \\
\hline Hartley & - & 42 & Yoakum & 63 & 41 \\
\hline Hemphill & 67 & 36 & & & \\
\hline Hockley & 36 & 50 & Mean & 54.9 & $53 \cdot 3$ \\
\hline Howard & 71 & 41 & Variance & $297 \cdot 4$ & 303.5 \\
\hline Hutchinson & 62 & 37 & & & \\
\hline
\end{tabular}

Notes:

1. For a more detailed discussion of the procedure see either E. Casetti and R. K. Semple: A Method for the Stepwise Separation of Spatial Trends. Ann Arbor, Mich.: MICMAG, 1968, or R. K. Semple, H. L. Gauthier and C. E. Youngman: Growth Poles in Sao Paulo, Brazil. Annals of the A.A.G., Vol. 62, 1962, pp. 592-595.

2. The routine finds the point of highest correlation qithin the region. The contours in Figures 4 and 5 obviously point to an origin outside the region.

rank as "metropolis" (BERRY 1973, Vol. II, p. 251). However, Amarillo's performance as a spontaneous growth center has not been so outstanding as Lubbock's. Also, Amarillo experienced a 3.4 per cent decline in SMSA population in the 1960 's while Lubbock's population grew by 14.7 per cent. Midland 
and Odessa are not ranked so high as Lubbock by BERRY (1973, Vol. II, p. 255); they are called "wholesale-retail centers". In addition, the Odessa SMSA grew by 0.9 per cent in the 1960's and the Midland SMSA population declined by 3.4 per cent.

With respect to the region under investigation, specific hypotheses can now be advanced. It is first hypothesized that growth impulses should radiate from the Lubbock area and the trend surface routine should located a "peak" in the regional growth trend there. It can also be hypothesized that secondary peaks should coincide with the Amarillo area and with the MidlandOdessa area (Midland and Odessa taken as an aggregate since they are often referred to as a "twin city"). These hypothesized centers will be identified as peaks if absolute change is used and as valleys or depressions if percentage change is used.

\section{OPERATIONALIZATION}

The trend surface routine requires a growth measure and the coordinates for the observations. For this study, the per cent change in the median family income has been selected as the measure of economic growth. It is felt that this measure best incorporates both spread and backwash effects. If a growth center was functioning as hypothesized, it would induce growth in economic welfare to the entire population with greater "percentage" changes in the periphery.

The unit of observation is the county. The per cent change in median family income for each county was calculated for the decade of the 1950's and for the 1960's (U.S. Bureau of the Census, 1962 and 1972). The coordinates of the individual observations were set in the center of the respective counties except in those counties which had a large city located near the county line. For instance. Amarillo is located near the southern boundary of Potter County. Since Amarillo accounts for most of Potter County's population, the coordinates for that observation were taken from the location of that city.

Several counties varied in their ability to report (due to disclosure roles) median family income from census to census. The fact that observations for several counties could not be made is not a matter of serious concern. The growth indicator has been treated as a continuous variable and the observations which are available are to be thought of as samples from a continuous surface. Table I (Appendix 2) lists the counties with their growth characteristics.

\section{RESULTS}

The analysis of growth in economic welfare was conducted for two different time periods to detect any temporal trends which might be discernible. Figure 3 depicts the regional trend in the income growth from 1950 to 1960 . A "depressed" area was the point of highest correlation. It can be generalized that the northern and southern parts of the region had greater growth rates than the generally depressed central region. The trend appears to be somewhat 


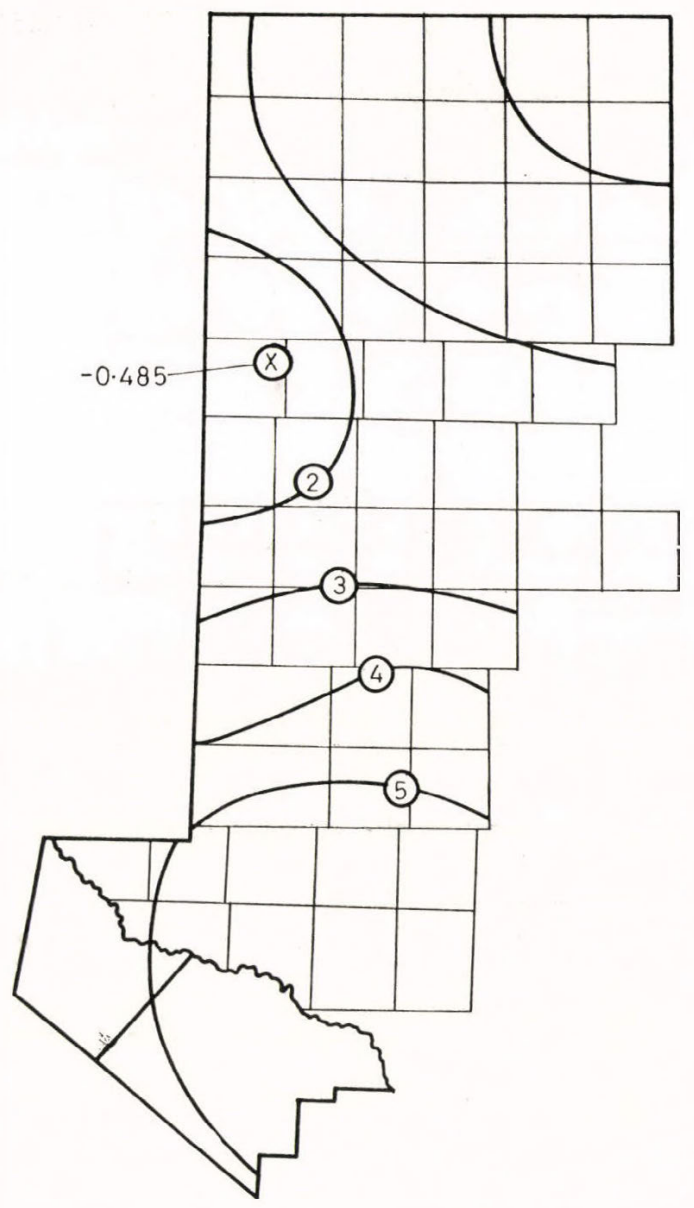

Fig. 3. Regional trends in income growth, 1950 to 1960

stronger in the south where oil and gas discoveries in the 1950's may have made the Midland-Odessa area into a radiator of growth impulses. The regional trend in Figure 3 explained 26.2 per cent of the variance in the growth values.

The point of highest correlation is in a central trough and there are relative peaks in the north and south. This trend appears to be reinforcing the regional trend in Figure 3 in a general way. This trend explained 10.7 per cent of the total variance and brought the total explained variance to 36.9 per cent.

Figure 4 represents the regional trend from 1960 to 1970. There was a rather distinct change in the growth pattern from the 1950 's to the 1960 's with the point of highest correlation being a peak in the 1960's rather than a depression as it had been in the 1950's. The regional trend is rather strong 


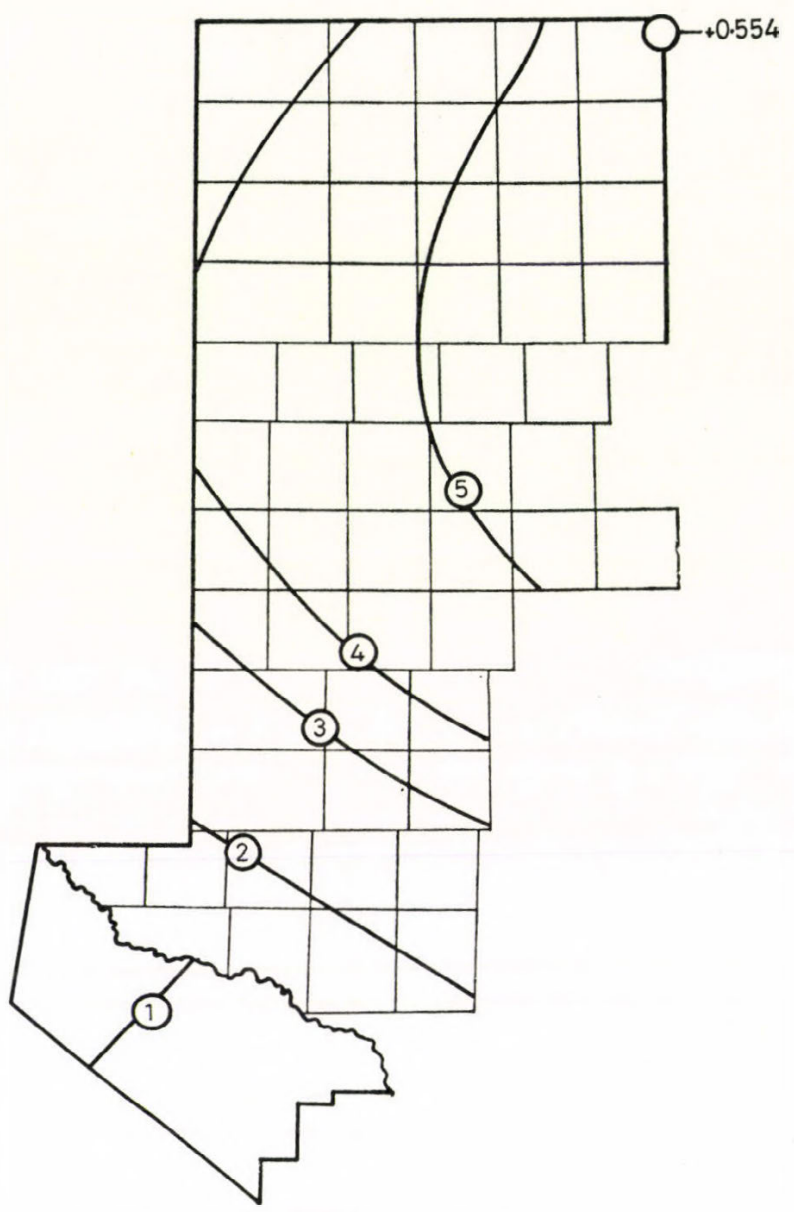

Fig. 4. Regionalltrends in income growth, 1960 to 1970

from the northeast to the southwest, explaining 35.3 per cent of the variance of the original distribution.

Figure 5 represents the trend associated with the residuals from the regional trend for the 1960's. As with the regional trend, there is a point of high correlation in the eastern part of the region with a general decline from that point in all directions in the region. The variance explained by the residual trend was 17.4 per cent, bringing the total explained variance to 52.7 per cent.

\section{CONCLUSIONS}

In light of the above results, it is necessary to reject both hypotheses without much argument. What polarity there is in economic growth cannot be 


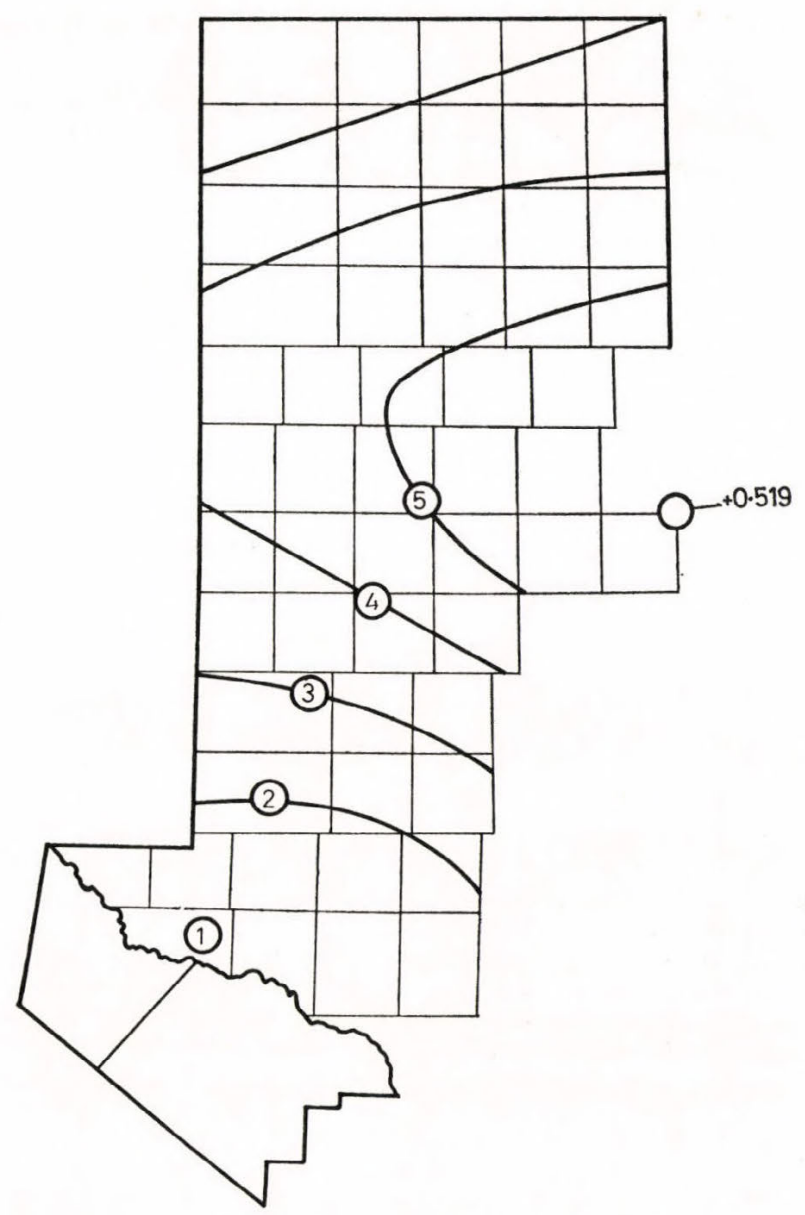

Fig. 5. Growth trends on Second Pass, 1960 to 1970

attributed to Lubbock as the primary center or to Amarillo and MidlandOdessa as regional centers. This rejection assumes, of course, that the growth measure was a valid indicator of performance. However, the results do bring up some interesting points concerning growth center in the High Plains and concerning growth center in general.

There appears to be an overall increase in polarity in growth in the region from 1950 to 1970 . The 1950's showed two relative peaks and a central trough, but the explained variance was only 36.9 per cent after two trend surfaces were extracted. The 1960's showed an obvious shift in the orientation of the polarity and an increase in the polarity (the explained variance was 52.7 per cent with two surfaces). 
While there was a temporal increase in polarity, there was an interesting shift in the orientation of the points of high correlation. The 1960 and 1970 results would lead one to believe that the growth stimuli are external to the region. The contour lines in Figures 4 and 5 point easterly for an origin. This would suggest a gradient of growth impulses radiating from possibly Dallas, Oklahoma City, or, more generally, the East Coast. This would suggest that economic growth in the High Plains is the result of stimuli from places higher in the urban hierarchy than Lubbock (BERRY 1972, p. 119).

The negative results might lend credibility to the idea that there is a threshold in population size that is necessary for a growth center to achieve before it can function properly as a propagator of spread effects; 250,000 is an often cited population threshold which is needed for a growth center to be effective (HANSEN 1972, p. 279). Lubbock's 1970 population was approximately 180,000 and the other SMSA's counties in the region were still smaller.

A conclusion which one would like to avoid concerns the notion of spread effects associated with natural growth centers. If the results of this evaluation are indicative of the performance of all growth centers, the entire strategy may be founded on an incorrect postulate.

\section{REFERENCES}

Alonso, W. and Medrich, E. (1972): Spontaneous Growth Centers in 20th Century American Urbanization. In N. M. Hansen (ed.): Growth Centers in Regional Ecconomic Development. New York: The Free Press, pp. 229-265.

Berry, B. J. L. (1972): Hierarchical Diffusion: The Basis of Developmental Filtering and Spread in a System of Growth Centers. In N. M. Hansen (ed.): Growth Centers in Regional Economic Development. New York: The Free Press, pp. 108-138.

Berry, B. J. L. (1973): Growth Centers in the American Urban System. Vol. I and II, Cambridge, Mass.: Ballinger Publishing Co.

Casettr, E. (1961): GEOFIT In W. R. Tobler (ed.): Selected Computer Programs. Ann Arbor, Mich.; Univer. of Michigan Dept. of Geography, pp. 1-18.

Casetti, E. and Semple, R. K. (1968): A Method for the Stepwise Separation of Spatial Trends. Ann Arbor, Mich.: MICMAG.

Cooley, W. W. and Lohnes, P. R. (1971): Multivariate Data Analysis. New York: John Wiley and Sons, Inc.

Darwent, D. F. (1969): Growth Poles and Growth Centers in Regional Planning-A Review. Environment and Planning, Vol. I, pp. 5-31.

DeAre, D. and Poston, D. L. Jr. (1973): Texas Population in 1970: 5. Trends and Variations in the Populations of Nonmetropolitan Towns, 1950-1970. Texas Business Review, Vol. XLVII, No. 1, Jan., pp. $11-16$.

Fuguits, G. V. (1971): The Places Left Behind: Population Trends and Policy for Rural America. Rural Sociology, Vol. XXXVI, Dec., pp. 449-470.

GrubB, H. W. (1973): The Structure of the Texas Economy. Vol. I, Austin, Tx.: Office of the Governor.

Hansen, N. M. (1970): Development Pole Theory in a Regional Context. In D. L. McKee et al. (eds): Regional Economics. New York, The Free Press, pp. 121-136.

Hansen, N. M. (1970): Unbalanced Growth and Regional Development. In D. L. McKee et al. (eds): Regional Economics. New York, The Free Press, pp. 229-241.

Hansen, N. M. (1971): Intermediate-Size Cities as Growth Centers. New York: Praeger Publishing.

Hansen, N. M. (1972): Growth Center Policy in the United States. In N. M. Hansen (ed.): Growth Centers in Regional Economic Deselopment. New York: The Free Press, pp. 266-281. 
Hansen, N. M. (1973): The Future of Nonmetropolitan America. Lexington, Mass.: Lexington Books.

Hansen, N. M. (1974): The Challenge of Urban Growth: The Basic Economics of City Size and structure. Study prepared for The National Science Foundation.

Hirschman, A. O. (1958): The Strategy of Economic Derelopment. New Haven: Yale University Press.

Hodge, G. (1971): Urban Structure and Regional Development. The Regional Science Association Papers, Vol. XXI, pp. 101-123.

KInG, L. J. (1967): Discriminatory Analysis of Urban Growth Patterns in Ontario and Quebec, 1951-1961. Annals of the Association of American Geographers, Vol. LVII, No. 3, Sept.

Morritu, R. L. and Wohrenserg, E. H. (1971): The Geography of Poperty in the United States. New York: McGraw Hill.

Myrdal, G. (1957): Rich Lands and Poor. New York: Harper.

Nichols, V. (1969): Growth Poles: An Evaluation of Their Propulsive Effects. Environment and Planning, Vol. 1, pp. 193-208.

Perroux, F. (1970): Note on the Concept of Growth Poles. In D. L. McKee et. al. (eds.): Regional Economics. New York: The Free Press, pp. 93-104.

President's National Advisory Commission on Rural Poverty (1968): Rural Poverty in the United States. Washington, D.C.: U.S. Government Printing Office.

Semple, R. K., Gauthier, H. L. and Youngman, C. E. (1972): Growth Poles in Sao Paulo, Brazil. Annals of the A.A.G., Vol. 62, pp. 591-598.

Trомаs, M. D. (1972): Growth Pole Theory: An Examination of Some of its Basic Concepts. In N. M. Hansen (ed.): Growth Centers in Regional Economic Deselopment. New York: The Free Press, pp. $50-81$.

U.S. Bureau of the Census (1962 and 1972): City and County Data Book, 1962 and 1972 Washington: G.P.O.

U.S. Bureau of the Census (1971): U.S. Census of Population: 1970. Number of Inhabitants. Final Report PC (1)-A45 Texas. Washington, D.C.: U.S. Government Printing Office, Table 8, "Population in 1970 of Areas Annexed Between 1960 and 1970".

Veldmax, D. J. (1967): Fortran Programming for the Behasioral Sciences. New York: Holt, Rinehart, and Winston. 



\section{AN EVALUATION OF THE FUNCTIONAL DEVELOPMENT OF RURAL SETTLEMENTS USING EDUCATIONAL ATTAINMENT AS AN INDEX OF METHODOLOGY}

By

BÉLA SÁRFALVI

Analysts of the hierarchical structure of the settlement system have applied numerous methods to describe the concept of centrality. Most of these analyses rely upon natural indices as measures. The complex evaluation of heterogeneous functions, because of their diversity, has led to ample difficulties.

In order to avoid problems of this kind, it has become necessary to construct complex indices, reflecting all aspects of the roles of individual settlements, in accordance with the importance and real effect of each particular role. One of the widely applied synthetic indices - the number of telephone lines in a particular settlement - was applied by W. CHRIstaller. His method was further developed by American geographers in their comparative studies of interactions through telephone links between individual settlements and between settlements and their attraction areas.

This method has its application in the Hungarian context as well, though the validity of the application may be questionable, because the number of telephone links in most cases does not reflect the widening needs of the locality; investment policy and technological factors have their impact as well.

This paper gives an account of an attempt to apply different kinds of a complex index. Central activities of settlements can be evaluated by measurements of different kinds of jobs, means of production and institutions. Nevertheless, if we regard the population of a settlement, living and working there, as reflecting the functions of the settlement, the complex exploration of role may be carried out on the basis of certain characteristics of the population itself. The more developed and complex the role of a particular settlement, the more typical is the structure and composition of labour. The level of general education and special training of the population closely corresponds to the type, significance and importance of these functions.

For the study area a part of Hungary has been selected, where there are settlements of different character as regards social, economic and physical geography. The study area covers the North-East segment of the country: Borsod County with its mining areas and industrial zones, and the agricultural counties of Szabolcs and Hajdú, which are underdeveloped compared to national standards. On the other hand, while for the first two counties small villages are characteristic, the last is the territory of huge villages with scattered farms, and market-towns, unic to Hungary. These three counties comprise the study area for the evaluation of the educational level of the population.

Since it is higher education that plays the differentiating role in the level of qualification of the population, only completed educational cycles were taken into account. That is, persons completing elementary and secondary 


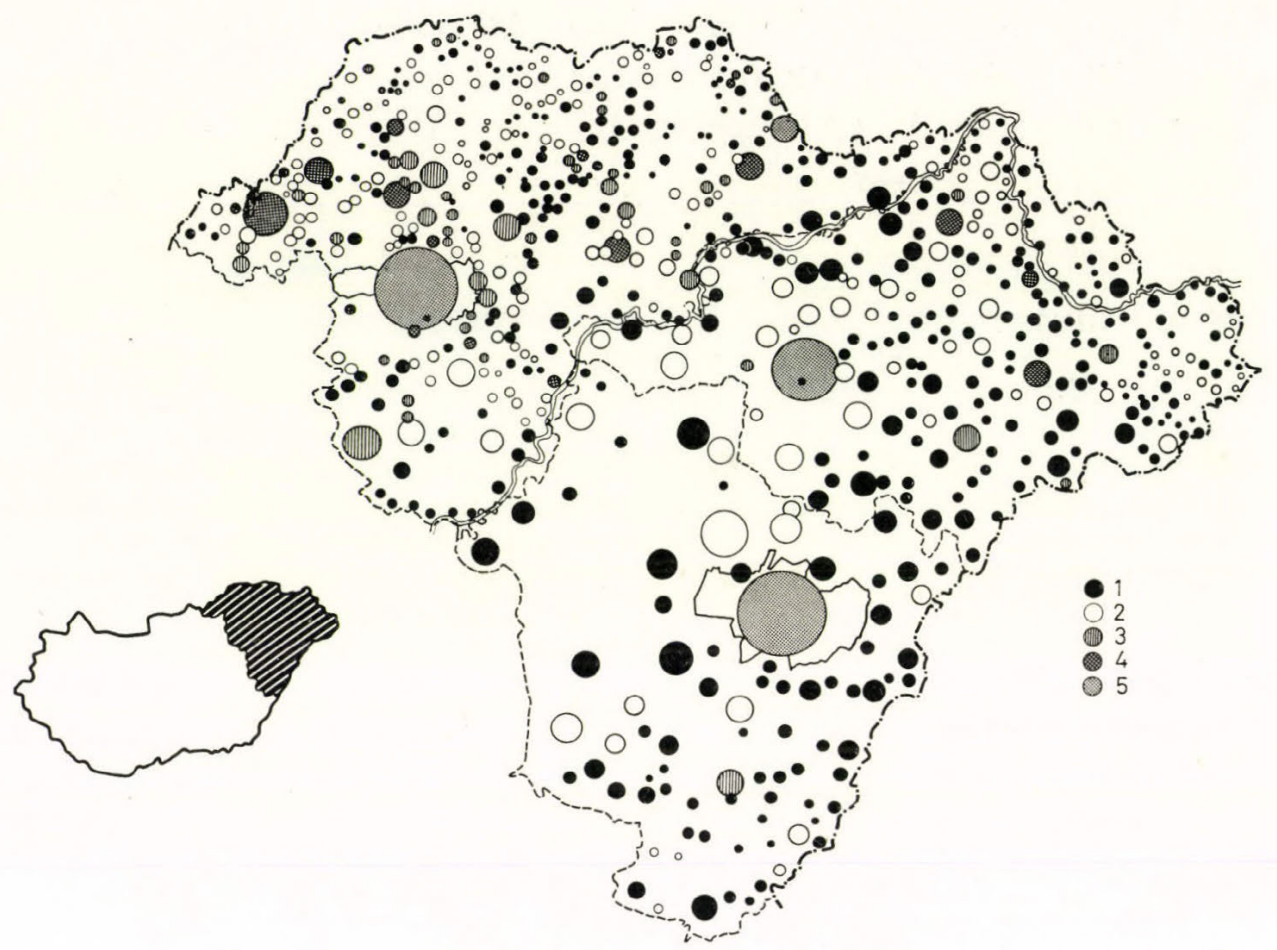

Fig. 1. Hierarchical structure of the settlement system of North-East Hungary on the basis of the educational level of the population in 1960. (Average length of completed educational cycles - years/person over fourteen.) The size of the circles is proportional to the population of the settlements

$1=<1 \cdot 59 ; 2=1 \cdot 60-2 \cdot 29 ; 3=2 \cdot 30-2 \cdot 99 ; 4=3 \cdot 00-3 \cdot 99 ; 5=4 \cdot 00-4 \cdot 99$

school, technical training schools and institutes of higher education were considered.

Ranking the different educational cycles was made in an additive way. Rank orders were made to accord approximately with the number of years of study and type of education. Rank sizes were then compared to the number of population above the age of fourteen, and the resulting index was used for determining the position of settlements in the hierarchy.

Complex educational indices for the population were enumerated for 1960 and 1970. Even though the symbol applied was the same for the two years, clusters dominating the 1960 map are almost missing from the 1970 map, due to the drastic change in the educational level of the population (Figs 1 and 2). The rapid cultural development of the sixties has affected precisely those comparatively underdeveloped parts of the country where the three selected counties are located.

There is a marked difference between settlements with central functions and their hinterlands in both years, although the level of education of both central 


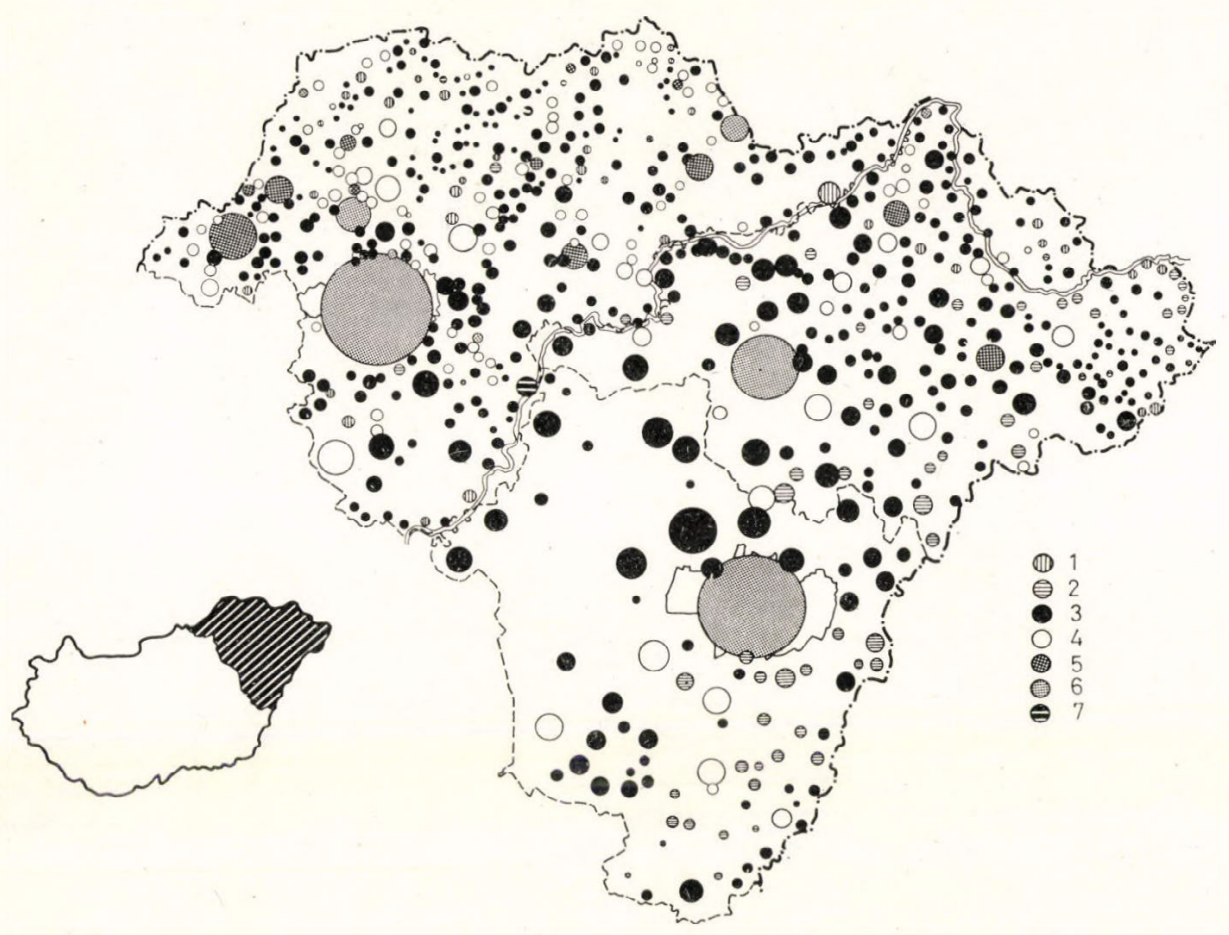

Fig. 2. Hierarchical structure of the settlement system of North-East Hungary on the basis of the educational level of the population in 1970. (Average length of completed educational cycles - years/person over fourteen.) The size of the circles is proportional to the population of the settlements

$1=1 \cdot 60-2 \cdot 29 ; 2=2 \cdot 30-2 \cdot 99 ; 3=3 \cdot 00-3 \cdot 99 ; 4=4 \cdot 00-4 \cdot 99 ; 5=5 \cdot 00-5 \cdot 99 ; 6=6 \cdot 00-6 \cdot 99 ; 7=7 \cdot 00<$

area and hinterland rose during the studied ten year period. At the same time, the number of settlements with a central role grew as well. Two distinctive processes in the development of the Hungarian settlement system and of belated, but rapid urbanization are reflected in these results. In the growing number of settlements with a central role, a kind of functional urbanization has been taking place, functions of urban type have been growing in these settlements, the range of their centrality has broadened including new elements.

At the same time, rural settlements have also been affected by urbanization and in these settlements the process of socio-economic urbanization has been taking place. This process had three main features, namely: their infrastructure has gone through a phase of obvious development, as a consequence of decentralization industrial production has been started in a growing number of rural settlements, and agriculture has entered a development period when labour with medium and high education qualifications plays a very important role. 


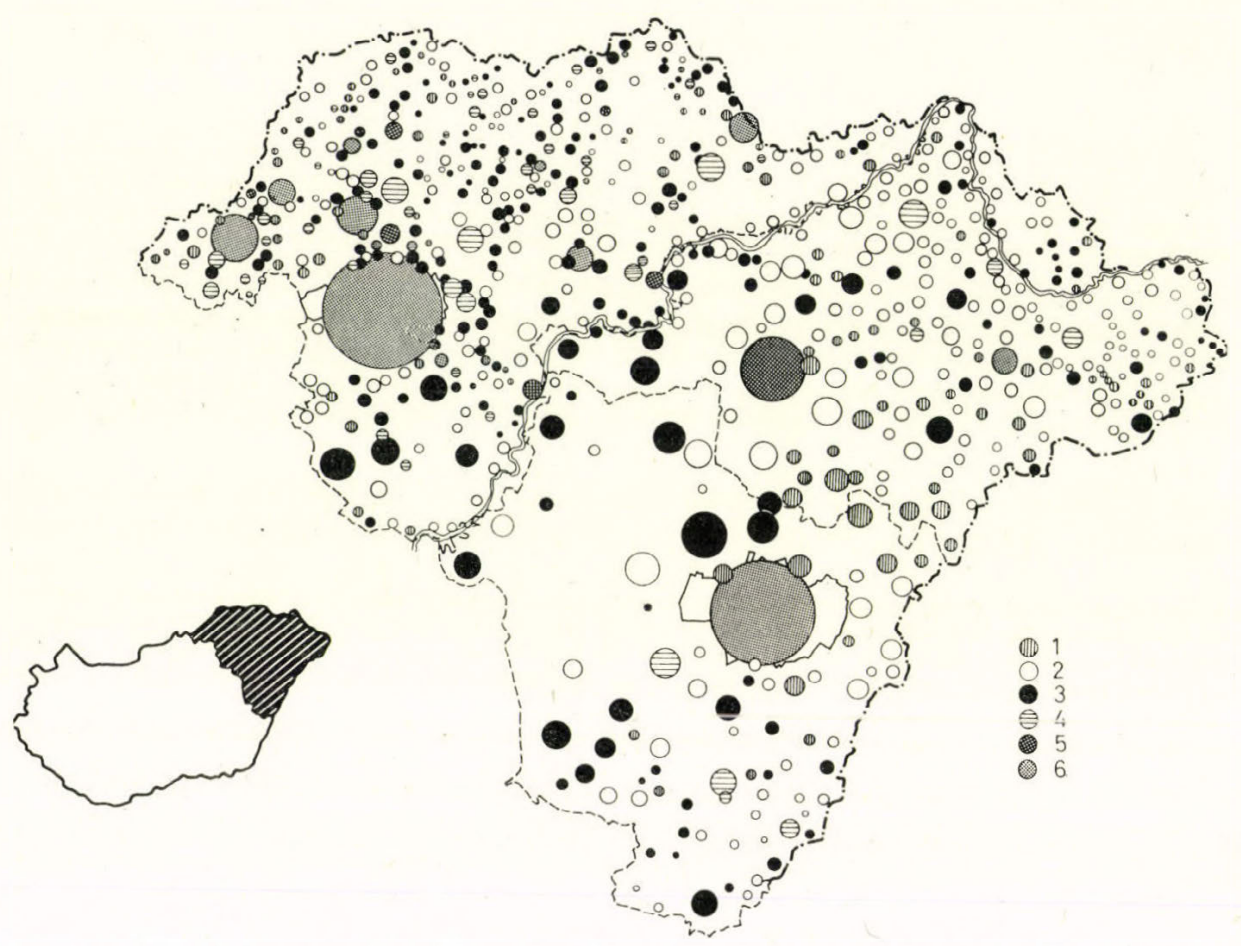

Fig. 3. Ratio of qualified workers in agriculture to total agricultural manpower in 1970. The size of the circles is proportional to the population of the settlements $(\%)$

$1=\langle 3 \cdot 5 ; 2=3 \cdot 6-6 \cdot 0 ; 3=6 \cdot 1-10 \cdot 0 ; 4=10 \cdot 1-14 \cdot 0 ; 5=14 \cdot 1-18 \cdot 0 ; 6=18 \cdot 1<$

These processes have resulted in a significant increase in the ratio of graduate employees among the active population of rural settlements.

In the course of infrastructural development the allocation of public, educational and health services has not only improved for the local population, but has attracted highly qualified, specialized labour into the area as well.

While the development of infrastucture has affected the whole area almost evenly, decentralization of industry has effected first of all the settlements in County Borsod, where industry has a comparatively long history. Nevertheless, the number of settlements having at least 250 industrial employees or more has increased fairly rapidly in the whole study area.

Following the transformation of agriculture into large-scale farming, the last fifteen years have been marked by technological development. Training and recruiting qualified labour for agriculture was the precondition for introducing and applying up-to-date methods of production. The number of workers occupied in manual labour in agriculture has been continuously diminishing (Fig. 3). During the last period industrialization of agrarian production has accelerated. As the level of agriculture in the three counties 
does not reach the highest national levels, general development has affected these areas only moderately.

Five to ten per cent of the working population of high- and medium-grade towns are graduates of institutes of higher education, and the proportion of highly qualified labour is around $2-3$ per cent even in developed rural settlements. In backward and stagnating villages these proportions are negligeable.

A comparison of the pattern of educational level with the settlement hierarchy laid down in the national plan, makes it clear that the pattern we have come to by the method applied is congruent with the pattern of settlements in the plan.

It can be clearly seen that an evaluation of the educational level of the population shows that the settlements in County Borsod - despite the numerous small villages in this area - are more developed (due to the industrialization here) than those in counties Hajdú and Szaboles.

The proportion of settlements belonging to clusters less developed is $0 \cdot 3$ per cent in Borsod, $5 \cdot 2$ per cent in Szaboles and $6 \cdot 0$ per cent in Hajdú County. The proportion of settlements with populations of average educational level is 51.7 per cent in Borsod, 82.1 per cent in Szaboles and 84.3 per cent in Hajdú. The proportion of settlements with population above the average level of education are $42 \cdot 3,10 \cdot 0$ and 8.4 per cent, respectively, while those of very high educational level are $5 \cdot 7,2 \cdot 7$ and $3 \cdot 3$ per cent respectively. The vertical axis of the diagram ranks the educational level of population of the settlements range from 1 to 8 (see the legend of Fig. 1), along the horizontal axis the hierarchical stages of settlements range from $A$ to $H$.

$A$ : denotes high-grade centers of high priority, performing functions of national importance along with functions extending to several counties;

The scattering of the educational level of the population of the central places in the study area

\begin{tabular}{rrrrrrrr}
\hline 8 & \multicolumn{1}{c}{1} & & & & & \\
\hline 7 & 2 & 1 & 2 & 1 & & & \\
\hline 6 & 5 & 1 & 3 & 3 & 2 & \\
\hline 5 & 4 & 3 & 9 & 14 & 1 & 13 \\
\hline 4 & 1 & 2 & 24 & 70 & 13 & 25 \\
\hline 3 & & & & 1 & 12 & 3 & \\
\hline
\end{tabular}

2

1

$\begin{array}{llllllll}A & B & C & D & E & F & G & H\end{array}$


$B$ : denotes high-grade centers usually with functions for one particular county;

$C$ : denotes partial high-grade centers with some particular organizational and governing functions;

$D$ : medium-grade centers with medium-range functions in the economy, government, education, health service and other kinds of services for self-contained parts of a particular county;

E: denotes partial medium-grade centers with medium-grade functions shared with other more developed settlements;

$F$ : denotes special low-grade centers with functions for greater areas than their locality;

$G$ : low-grade centers with functions for the locality;

$H$ : denotes settlements belonging to a metropolitan agglomeration.

The basic transformation of Hungary to an industrialized country, resulted in the spatial restructuring of the population. Rural population diminished drastically in number, especially during the ten year period between 1950 and 1960, and at a rate exceeding the national average in the study area. Net migration was negative in the study area during the last decade, even though the rate of emigration had diminished, or rather that modest immigration of specialized labour had alleviated it.

Due to the high rate of local natural increase and due to the fact that large villages are characteristic of many parts of the study area, permanently high gross emigration has affected these areas to a lesser degree than the numerous western counties where small villages had previously been characteristic, thousands of them disappearing during the period of industrialization. Most of the settlements in the three counties studied still continue to gain population despite the fact that other counties reached their maximum in 1960. Examples of continuous loss of population can be found in small villages only. 


\section{IIUNGARY'S RURAL INDUSTRY}

By

GYÖRGYI BARTA

Even in the period preceding World War II, Hungarian industry was characterized by high concentration, mainly as a result of the fact that capitalist industrialization started in Hungary later than in the more developed western European countries. In spite of this, however, handicrafts also played an important role in industrial production. Besides the large industrial factories there were a lot of medium-sized and small plants as well. By way of illustration, in 1938 two thirds of the entire industrial output was produced in factories employing less than 500 workers.

After 1945, industrial concentration continued to increase. In the course of nationalization a great number of small plants were wound up, amalgamated or joined with larger enterprises. Industrial development affected first of all heavy industry, since due to its technological features it primarily requires the creation of large industrial factories. At the same time traditional rural handicraft was gradually decreasing. The sudden suppression in the villages of some services of an industrial kind (privately owned small repairing and servicing shops employing only one or two persons) due to the levying of disadvantageous taxes also contributed to reducing rural industrial activities.

The most fundamental change came in 1962-1964. During this period the number of the state-owned industrial enterprises diminished by one third; the average labour force, however, almost doubled.

Although in the early sixties similar reorganizations, amalgamations and fusions were also carried out in all other European socialist countries, such a high concentration as in Hungary has nowhere been created. It is for instance characteristic that while in Hungary over one third of the workers are engaged in industrial enterprises employing more than 5,000 workers, the same figure in the Soviet Union accounts for only 22 per cent, and in the majority of the CMEA countries - for only 16 per cent.

In accordance with this, at an international level the Hungarian share of those working in industrial enterprises employing less than 100 workers is one of the lowest. This only applies to the figures for state-owned and cooperative industries, as this paper does not deal with private-owned small-scale industries, nor with the industrial activities of cooperatives (Table I).

Technical progress generally requires industrial concentration, despite the fact that in many countries the ratio of small plants does not indicate any major decrease. (For example in the USA the ratio of small plants employing less than 100 persons has not decreased during the past fifty years. On the contrary, the number of persons employed in them has almost doubled.) 


\section{TABLE I}

Industrial settlement structure by number of persons employed

\begin{tabular}{l|r|r|r|r|r}
\hline \multirow{2}{*}{ Country } & \multicolumn{5}{|c}{ Ratio of industrial settlements employing persons } \\
\cline { 2 - 6 } & below 50 & $51-100$ & $101-500$ & $501-1000$ & 1000 and more \\
Hungary & $5 \cdot 1$ & $5 \cdot 3$ & $21 \cdot 7$ & $16 \cdot 9$ & $51 \cdot 0$ \\
FRG & $9 \cdot 6$ & $8 \cdot 7$ & $28 \cdot 7$ & $12 \cdot 3$ & $39 \cdot 8$ \\
USA & $14 \cdot 1$ & $10 \cdot 2$ & $31 \cdot 3$ & $12 \cdot 8$ & $31 \cdot 6$ \\
France & $23 \cdot 4$ & $12 \cdot 8$ & $32 \cdot 3$ & $11 \cdot 0$ & $20 \cdot 6$ \\
Japan & $31 \cdot 2$ & $13 \cdot 5$ & $26 \cdot 1$ & $9 \cdot 4$ & $19 \cdot 8$ \\
Sweden & $22 \cdot 0$ & $12 \cdot 8$ & $33 \cdot 7$ & $13 \cdot 0$ & $18 \cdot 5$
\end{tabular}

Source: Az ipar nemzetközi összehasonlításban (Industry in International Comparison). Hungarian Centra Statistical Office. Statisztikai Idôszaki Közlemények (Statistical Periodical Proceedings).

Concentration is, as a rule, typical of heavy industry throughout the world. It is, however, very interesting that in Hungary, contrary to the general tendencies, considerable concentration has taken place in the light and food industries as well. The reason for this is that heavy industry was highly concentrated even in the period preceding World War II (Table II).

\section{TABLE II}

Extent of concentration in some industrial branches; proportion of industrial settlements employing more than 1000 persons

\begin{tabular}{l|c|c|r|r}
\hline \multicolumn{1}{c|}{ Country } & $\begin{array}{c}\text { Engineering } \\
\text { industry }\end{array}$ & $\begin{array}{c}\text { Chemical } \\
\text { industry }\end{array}$ & $\begin{array}{c}\text { Textile } \\
\text { industry }\end{array}$ & $\begin{array}{c}\text { Food processing } \\
\text { industry }\end{array}$ \\
\hline & & & & \\
Hungary & $64 \cdot 5$ & $55 \cdot 7$ & $71 \cdot 0$ & $31 \cdot 6$ \\
FRG & $69 \cdot 2$ & $47 \cdot 4$ & $18 \cdot 2$ & $11 \cdot 9$ \\
France & $30 \cdot 9$ & $24 \cdot 1$ & $10 \cdot 3$ & $2 \cdot 2$ \\
Japan & $28 \cdot 2$ & $35 \cdot 4$ & $9 \cdot 9$ & $3 \cdot 8$ \\
United Kingdom & $50 \cdot 1$ & $45 \cdot 2$ & $10 \cdot 7$ & $30 \cdot 9$ \\
& & & &
\end{tabular}

Source: as above.

However, the indices indicating such a highly concentrated Hungarian industry are to some extent delusive in view of the fact that a major part of our large factories are not really large. The index numbers often indicate only formal amalgamation of several smaller industrial establishments, while in part of these combined plants, technology of production, equipment, organization and management have remained at the former low level.

Taking this into account, however, it must be pointed out that the present degree of Hungarian industrial concentration is to a great extent exaggerated. The low ratio of small and medium-sized plants has reduced the efficiency of contemporary large-scale production, contributing to the occurrence of continuous shortages of consumer goods and choice of supply. 
The high organizational and industrial concentration of production continued to increase owing to regional industrial concentration. The heredity of capitalist Hungary, that is high industrial development in Central and Northern Transdanubia, in the capital and in the Northern Hungarian Central Mountain region, but at the same time economic backwardness in the Great Hungarian Plain and Southern Transdanubia, could not be essentially changed by developing socialist industry in Hungary. The reason was primarily that the one-sided development of heavy industry in the post-war period continued to depend on the coal sources situated in the above mentioned industrialized areas.

The first major efforts aimed at eliminating the disadvantages deriving from the lack of small and medium-sized plants, regional differences in industrial level, and one-sided industrial development were taken only in the sixties.

The share of light industrial investment has been raised, and full-scale reconstruction of several branches, for instance that of the textile industry has begun.

In 1958 the HSWP Central Committee adopted its first resolution concerning the creation of a Central Fund for Regional Development ${ }^{1}$ to promote the reduction of regional, economic, and above all industrial differences. Industrialization of the Great Hungarian Plain began, the main goal of which was to ensure local industrial labour opportunities for labour freed from agriculture. Therefore branches with a highly-fabricated production pattern requiring low capital intensity, particularly engineering, light and food industrial plants, have become typical in the development of the Great Hungarian Plain.

Selective industrial development in the capital also contributed to changing Hungary's regional industrial structure. It brought about the removal of a great number of plants from the capital to rural areas. More intensive development of the provinces and curbing industrial development in the capital itself reduced the share of Budapest's industrial production from 39 per cent in 1960 to 32 per cent in 1970. The number of persons employed in industry decreased in the period between 1963 and 1975 by about 100,000.

It was also in the late sixties, early seventies that a structural transformation of energy production took place having far-reaching regional effects. In the early sixties nearly 75 per cent of Hungary's power demand was covered by coal. In the late sixties and mostly in 1971-1972, however, a number of coal mines operating uneconomically were closed, especially in Nógrád and Borsod counties, in order to make coal mining more economical. The re-employment of nearly 20,000 miners could be partly solved only by the location of new industrial plants in the same area.

The economic reform introduced in 1968 had a favourable effect on the industrial development of areas still having surplus labour. The economic reform ensured a greater independence for the enterprises. For instance, they themselves were allowed to dispose of a considerable part of their development funds created from their own profits. In many cases these enterprises spent a part of their production investment on establishing new industrial plants in

${ }^{1}$ A fund created in order to develop industrially backward areas, offset reduction of coal mining, and further removal of some of Budapest's industrial plants to rural areas. 
the country in smaller settlements, since on the spot they could hardly find any surplus labour. In 1968, the number of small plants removed to rural areas suddenly increased.

In this short introduction we have pointed out some elements of the organizational, regional and branch particularities of Hungarian industry, and tho of Hungarian economic policy respectively (industrial and regional development) which had a direct or indirect effect on the development of rural industry as well.

The fifth five-year plan period (1976-1980) indicates some changes in the development of rural industry. Industrial and regional planning have involved more concentrated investment than earlier. It will not often be for creation of new industrial establishments, which can lead to a slowing down, stagnating or even curbing of rural industry. More concentrated industrial development is required primarily by the labour shortage prevalent throughout the country.

Undoubtedly, the small rural plants, grown in great number, have also contributed to absorbing the mobile labour force. In another development, the rapid spreading of small rural plants has resulted in the squandering of investment goods. A number of small industrial plants were established in old buildings set up for other purposes with minimal investment, making use of outdated equipment, worn out partly or entirely in large factories. In addition, there was only unskilled, or inexperienced labour available.

As a result of this, in some of these small rural plants labour productivity has not reached the required standards.

Of course, this is not typical of rural industry as a whole. The overwhelming majority of rural industrial establishments have succeeded in achieving results close to the national average, even if their production started under disadvantageous conditions. There is no doubt, however, that the working and living conditions of the local population have been favourably affected by these new industrial plants.

\section{RURAL INDUSTRY TODAY}

Industries removed to rural areas represent a significant part of Hungarian industry as a whole, considering that approximately 20 per cent of all industrial workers are employed there. The number and importance would be even greater, if the auxiliary industrial activities of farming cooperatives ${ }^{2}$ were to be included as well.

Certainly, it is to be noted that a further 20-25 per cent of industrial workers have been commuting daily or at longer intervals from the villages to the factories in the towns. In the early seventies in about 400 (out of a total of 3000) Hungarian villages, more than 50 per cent of all active population was employed in industry.

Rural industry indicates no specific peculiarities with regard to the structure of its branches. In the combined index numbers characterizing the division of branches, there is only a minimal difference between the proportion of

2 That is to say the industrial and servicing activities of farming cooperatives. 
heavy, light and food industries in the villages and the national level, respectively (Table III).

In the structure of branches reduced to industrial groups there is some difference between rural and national patterns. The high share of mining and Bitilding material industries in rural areas is a typical phenomenon. The proportion of the food industry is, however, surprisingly low. In this case the figures are slightly distorted as auxiliary industrial activities are mostly of a food-industrial kind.

\section{TABLE III}

Structure of industrial branches on the basis of the share of persons employed in rural industries and at the national level, respectively (in per cent)

\begin{tabular}{l|r|r}
\hline & $\begin{array}{c}\text { In rural in- } \\
\text { dustries }\end{array}$ & $\begin{array}{c}\text { At the national } \\
\text { level }\end{array}$ \\
\hline Mining industry & 14 & 8 \\
Electric power industry & 1 & 2 \\
Metallurgy & 2 & 6 \\
Engineering industry & 31 & 31 \\
Building material industry & 8 & 5 \\
Chemical industry & 4 & 6 \\
\hline Heasy industry & 60 & 58 \\
\hline Light industry & 25 & 27 \\
\hline Food industry & 9 & 11
\end{tabular}

In rural industries the predominant branches are those processing raw materials available on the site.

Rural industry's stocks of fixed assets and their share of machines and equipment also amount to about one fifth of all the industrial fixed assets and machinery of the country as a whole. But this only applies to gross valuations, because net values (reduced by amortization) are lagging behind the national level.

About 45 per cent of those, employed in rural industry are women. It is not surprising that the share of women earners is slightly superior to the national average ( 43 per cent), because the overwhelming majority of commuters are men.

No data are a lable concerning the production value of rural industry. Production da, nave been registered only with respect to industrial enterprises as a whole, without going into details for each industrial settlement. For the most part rural industry does not consist of independent plants and the rural share of production by values would by no means reflect the actual situation.

Development of productivity represents the most crucial point of rural industrial production in removing plants to rural areas. We have no comprehensive knowledge of the productivity of rural industry as a whole. But observation indicate that it is below the national level. There are various 
reasons for this unfavourable phenomenon. Out-of-date buildings and machinery and the unskilled labour force have already been mentioned above.

Fluctuation of labour in rural plants exists to a lesser extent than in the urban ones. Fewer opportunities for choice between places of work compel the workers to adapt themselves to the actual situation.

However, this effect from the point of view of the factory is hardly felt because of the introduction of the new child-care allowance system. In plants employing mainly women, the share of those receiving the three-year childcare allowance (which in case of the birth of three children can be extended to 8 years) frequently accounts for $20-40$ per cent of the total number of employed. For the time being their proportion is steadily growing.

At urban plants the number of the women making use of the child-care allowance is lower, and many of them return to work before their three-years has expired. As a rule, at urban plants the division of the workers by age and sex is more balanced, and there are also more opportunities for accommodating infants in nurseries.

The central plants themselves often contribute to lower productivity levels by having their rural establishments do all the underpaid working processes which require less qualified work.

Lower productivity, unskilled labour force and shorter period spent in industrial work must eventuate in a lower wage level for those employed in rural industries. In 1975 the lag behind national and urban industrial levels amounted to 8-10 per cent.

\section{REGIONAL DIFFERENCES IN RURAL INDUSTRY}

The proportion of persons working in rural industry is extremely different in each county. It scarcely achieves 8 per cent in Gyôr-Sopron and Csongrád counties, as against more than 60-70 per cent in Pest and Tolna counties. Obviously, this depends not only on the spread of rural industry, but also on the size and settlement network of urban industry.

The proportion of labour engaged in rural industry shows, however, smaller fluctuation among the counties. Their rate ranges from 34 to 58 per cent.

In rural industry there is a close relationship between the division by sex and the level of workers' wages. In counties with average wage level (Fejér, Heves, Veszprém, Borsod-Abaúj-Zemplén, Nógrád) the ratio of women employed is the lowest. The reason for this is either that in view of the higher earnings of the men there is no need for the womens' earnings (in the above-mentioned counties mining and heavy industries prevail), or wage levels in these counties are higher in consequence of the less retarding effect of the lower wages of women. In extreme cases the wage level differences among the counties are more than 30 per cent.

The particular natural and economic endowments of the regions concerned also manifest themselves in regional differences of branch structure.

In the Transdanubian and Northern Central Mountain region, as well as in Baranya county, where Hungarian coal mining is carried on, or in South-West Transdanubian and Csongrád county, that is in the areas of oil production, 
20-40 per cent of total industrial earners are engaged in mining. The construction industry, too, is mostly linked with these deposits, especially in the Transdanubian counties. In the main agricultural areas (the Great Hungarian Plain, the Plain in North-West Hungary) the share of the food processing industry has risen above the national average.

Engineering is represented to a considerable degree in all counties in view of the fact that in the backward areas highly-fabricated engineering branches having only loose connection with the localities have been established. In previously exclusively agricultural areas the ratio of persons employed in engineering has increased by up to 25-45 per cent. (In Békés county 29 per cent, in Hajdú-Bihar county 44 per cent, in Somogy county 38 per cent, in Szaboles-Szatmár county 24 per cent.)

Development of light industry has been relegated into the background in the regions where mining and heavy industry are dominant. However, this means not only proportional differences, but also absolute lags compared with other counties. (In these counties the ratio of persons employed in light industry amounts to only 7-8 per cent). One-sided industrial structure offers less opportunities for employing women.

\section{THE MEANS OF RURAL INDUSTRIALIZATION}

Up to now there has not been in Hungary any branch or regional development policy preferring rural industrial development. The introduction of auxiliary industrial activities on farming cooperatives contitutes a marginal case. Its immediate goal was the strengthening of farming cooperatives economically. But later the sphere of auxiliary activities had to be limited in order that farming cooperatives might concentrate their efforts primarily on agricultural production. As a result of the modified taxation system introduced in the early seventies, farming cooperatives have become interested chiefly in food processing.

Since introducing the economic reform, the decision-making functions of enterprises have been broadened in the field of investment, too. Now it is the enterprise itself that decides on how to use its own profits, as well as part of the amortization. About 60 per cent of the national investment is financed from enterprise investment funds. It is this framework that virtually exclusively serves the purposes of creating and developing rural industrial establishments.

Regional regulators and other official prescriptions constitute important means of realizing regional objectives.

It was in 1971 that a Central Fund for Regional Development was created for the purpose of developing backward regions. This fund is expected to promote the solving of three major regional problems. In the course of the Capital's selective industrial development a number of industrial plants are being removed to rural areas. The costs of creating new rural industrial settlements are being covered partly by the Capital's Fund for Industrial Relocation. During the period between 1971 and 1975 this Fund of about 800 million forints accounted for some 13-15 per cent of all investment in the provinces. 
The fund created for developing backward areas accounts for nearly 25 per cent of the Central Fund for Regional Development. It is from this that support is being given for industrial development of the Great Hungarian Plain and Southwest Transdanubia.

The fund for reducing coal mining has resulted the transformation of the economic structure of the areas concerned.

From 1971 to 1975 support was granted to nearly 200 investments from the Central Fund for Regional Development. About 30 per cent of the full amount of these 200 investments was covered by this support. About 60-70 thousand new work places were created by these investments. A great number of them has broadened urban labour opportunities, but about 50 of the new plants have come into being in small towns and villages.

The Regional Development Fund amounts to not more than 1 per cent of all industrial investment, yet by means of it some $1-5$ per cent of all the industrial investment was orientated towards the desirable areas. In the areas assigned for industrial development, even where the investment was supported from the Central Fund for Regional Development, advantageous credits can be made use of. For instance, the enterprises removed from Budapest to rural areas covered 24 per cent of the expenses of their relocation from bank credits. Above-mentioned advantages consist chiefly in setting lower requirements for the enterprises by the banks.

Local councils, too, can offer considerable support for relocating industrial plants. Industrial enterprises are obliged to credit 6 per cent of their profits, and farming cooperatives -1 per cent of their gross income of the territorially competent county council. These councils are entitled to promote the faster development of the enterprises by exempting them temporarily from their financial commitments. The county councils prefer, however, to make use of the possibility of granting preferential credits to the enterprises from their own industrial development funds.

Official regulations for implementing regional objectives are mainly of an administrative and only to a lesser extent of an economic kind. It was in 1975 that a National Plant Location Authority ${ }^{3}$ was set up in order to help the enterprises with the Location of new industrial establishments. Considering, however, that the Plant Location Authority has no financial resources at its disposal and that enterprises are not obliged to accept its recommendations, for the time being the Authority is hardly able to fulfil its tasks of orientating the location of new industry.

Being the top level organization managing the economy, it is the National Economic Committee which decides, for instance, on the plants to be removed from the Capital, and on the date of their removal.

Also the National Economic Committee has assigned 12 settlements in economically, mainly industrially backward areas, where the lag behind more developed regions is expected to diminish by means of concentrated industrial development.

${ }^{3}$ It provides settlement alternatives for the location of the enterprises, according to the objectives of the regional development. 


\section{AN OPTIMIZATION MODEL FOR RURAL SPACES}

By

TIVADAR BERNÁT

The traditional task of geographical research into rural spaces is the revelation of the spatial structure of agricultural production, the objective determination of agricultural regions, the regional types in connection with the natural and socio-economic factors influencing them.

From the point of view of economic policy and development planning the revelation of existing conditions in itself is not sufficient. So much that during recent years fact-finding investigations have strongly fallen into the background in the countries pursuing a planned economy. Today in most of the countries, as in Hungary, too, the determination of the already formed regional types, regions and their future transformation approximating the optimum, form one theme. Research into future regional location more and more relates to the investigation of rural spaces.

For the prognostication of development, it is necessary to analyze from among the system of relations of the agricultural region the permanent processes which can be described exactly and generalized (modelled). In this, mathematical methods play an important role. Thus, one branch of agricultural geography tries to find an answer to the following question: what would be the optimal agricultural structure of an area, the livestock and the most favourable production level on the basis of the most effective use of existing factors of production, and their optimal distribution respectively, within individual regional units (county, planning region, etc.). It is this tendency which characterizes the location theories of socialist agriculture, and which has emerged from the practice of agricultural regional planning. Also parts of up-to-date geographical theories in sestern countries are characterized by location theories which not only conceptually differ from the classic theories (J. H. Thünen, T. Brinkman, A. Lösch) but also methodologically use a new apparatus (W. IsARd, W. Alonso, E. O. Heady, D. KendrICK). The reason for this is that rural spaces are more heterogeneous and discontinuous than before, and therefore the investigation of them needs new methods.

In my lecture I whish to outline primarily the economic assumptions behind the mathematic models elaborated for Hungary, the mathematical method serving the solution of the model, and the degree of aggregation.

In the socialist countries the functions of mathematic models applied to the question of optimal location differ from those of the western countries. The maximalization of incomes, or the minimization of costs acts as the national economic level instead of the enterpise level, or as a summation of the latter. Regional models are also divergent in that the socialist countries aim at agricultural self-sufficiency, and beside this, a considerable export 
within the frame of their given possibilities. Consequently, also the minimum quantities of some basic products are included in the conditions of the programme. The evaluation of agricultural land regarded as fixed is entirely different, for in the socialist models it has no free market value and hoarding does not exist.

Since the location models of western countries also aim at the optimal realization of some economic assumptions, targets (objective functions) within given conditions and limits, there are a lot of identities between the methodological apparatuses used in western and in the socialist countries. Many of the mathematic models elaborated in the United States are utilizable also by us.

Formerly, in Hungary experiments were made with input-output models, but in recent years attention has been directed mainly towards linear programming models. However, now, the testing and use of aggregated systems of models have come to the fore. The basis of the models are the long-range concepts of economic policy. If the chief production indices (yields) scheduled for agriculture, the resources available (machines, artificial manure) and the productive forces attached to the regions (labour force, buildings) are given, then it becomes feasible to effectuate the optimal distribution of productive forces and production tasks in rural space which maximizes the contribution of agriculture to the national income. We want to find the production optimum within the inherent characteristics of individual rural spaces. These inherent characteristics are determined by the physico-geographical conditions of individual areas, sites and by the relationship between the labour force and assets available. Of course, the relationship of the three fundamental elements depends also on the macroeconomic environment: on the systems of price, subsidy and taxation.

\section{CHARACTERISTICS OF THE MODEL}

In the elaboration of optimal location non-central decision levels must be considered. The level of operative decisions is the national economy, that of regional planning is the country. Therefore, the model must express the decision interests of the enterprise (beside the interests of the national economy); moreover optimal location must be given by counties (at the decision level of operative regional planning).

From among possible optimum criteria, a single decisive criterion cannot be selected, it is reasonable to calculate more variations of location employing final functions of economic contents.

The location model has to reckon with the relations between manufacturing industry and agricultural production.

The location model provides the optimal use of the existing resources in the regional units. A part from the land, resources (labour force, irrigation plants, etc.) can regionally be redistributed. In long-range plans the location model can also contain the optimal location of resources, but this is not elaborated by us.

To elaborate optimal location, we have used linear programming, although this method has some deficiencies: obviously, optimal location has non- 
linear connections. In addition, the linear programming model is static: though it gives the optimal location we do not obtain information about the method and time of its achievement. The linear programming model can be made dynamic, but implies an increase in size beyond our computing facilities.

\section{A MATHEMATIC MODEL OF THE OPTIMAL USE OF THE RESOURCES OF RURAL SPACES}

\section{PRECONDITIONS OF THE FORMULATION OF THE MODEL}

The model defines the structure of production of regional units allowing the optimal achievement of the purposes formulated by the objective function within specified constraints. The model locates individual products, thus, specifies the sowing area of plants, and livestock for regional units (for counties in this case).

The applicability of the model required the building-up of the three groups of constraints: production rules, limits of resources and other constraints. Since optimal location must also provide the widest possible assortment in covering national economic demands, we have prescribed that the output of different products should not be less than that of the year of investigation (1969). The limits of resources ensure that the programme realizes the optimal location with the resources available - namely, land, capacities of machines, building and labour - and, in the case of livestock, with the production capacity of local roughages. Other constraints indicate the lower or upper margins referring to individual products or regions.

The location model is elaborated for the cooperatise sector and, therefore, can only be applied to the agricultural area occupied by this sector (however, the bulk of the agricultural area). As there were no suitable cost and income data available for the entire cooperative sector, we have used instead representative data, namely, the cost and income data of 300 cooperative farms. Generally they represent satisfactorily the total number of cooperative farms. Evidently, the data reflect the price conditions valid in the year of investigation.

Optimal locations were only calculated for the 12 most important products, and group of products, respectively. These make up more than 80 per cent of gross agricultural production. Our purpose was to elucidate the main trends of regional development and regional specialization, and to neglect crops of less importance produced in some parts of the country (rice, flax, etc.) was therefore deemed allowable by us. The 12 products, or branches are the following: 1. winter wheat; 2. winter and summer barley; 3 . maize; 4. sugar beet; 5. tobacco; 6. sunflowers; 7. potatoes; 8. field vegetables (paprika, tomato, onion, paprika for spice, green peas); 9. lucerne; 10. cattle; 11. pigs; 12. poultry. Fruit production and viticulture as well as grazing and pasturing which require a special locational programme were ruled out, in advance, from the optimal solutions. 
Our task is defined as follows: to determine the optimal variant of production by which it is possible to provide the real production output achieved in 1969 in a composition characterizing the year; production will be replicated at an unchanged level at least, and production capacities will be used with the highest effectiveness in order to achieve the purposes formulated by the objective functions. The objective functions contain four economic aims:

- maximization of net income,

- maximization of gross production value,

- minimization of production costs,

- maximization of gross income.

The programme is not of prognostic character, its parameters are not target- but actual figures. They are not plan-variants, but are a means of preliminary decision-making.

Variables of the model: $x_{i j}$ indicates what the production of product " $j$ " should be in county " $i$ ":

$$
\begin{aligned}
& i=1, \ldots, 19 \\
& j=1, \ldots, 12
\end{aligned}
$$

The value obtained for $x_{i j}$ gives the optimal output for crop production in cadastral yoke, and in livestock units.

The model has the following conditions:

1) no product may have a negative production volume planned for any county;

2) the agricultural area required by the crop defined for the individual counties by the programme must not be larger than the actual area available;

3) labour demand must not exceed the labour force available for any given county;

4) the machine demand of the specified products must not exceed the county's machine capacity;

5) the cattle- and pig-stock must not exceed 125 per cent of the county's stock in the year 1969;

6) the production volume - by products - must not fall short of the volume of 1969 ;

7) the sown area of field vegetables should not be reduced anywhere in the country;

8) and 9 barley, maize and other cereal fodders must cover the total livestock need of the country.

The above-mentioned facts were expressed by the formulation of 71 conditions and 38 individual constraints.

The objective functions of the model are:

$$
\begin{aligned}
& \mathrm{C}_{\mathrm{I}} \sum_{j=1}^{19} \sum_{i=1}^{12} d_{i j} x_{i j} \max ! \\
& \mathrm{C}_{\mathrm{II}} \sum_{j=1}^{19} \sum_{i=1}^{12} c_{i j} x_{i j} \min !
\end{aligned}
$$




$$
\begin{aligned}
\mathrm{C}_{\mathrm{III}} \sum_{j=1}^{19} \sum_{i=1}^{12}\left(c_{i j}+d_{i j}\right) x_{i j} & \max ! \\
\mathrm{C}_{\mathrm{IV}} \sum_{j=1}^{19} \sum_{i=1}^{12}\left(v_{i j}+d_{i j}\right) x_{i j} & \max !
\end{aligned}
$$

where

$d_{i j}$ - per unit net income that can be produced by product " $j$ ", in county " $i$ " (Forints) cadastral yoke, and Forints per livestock unit

$c_{i j}$ - per unit cost of product " $j$ ", in county " $i$ " (Forints) cadastral yoke, and Forints per livestock unit

$s_{i j}$ - per unit wage demand of product " $j$ ", in county " $i$ " (Forints) cadastral yoke, and Forints per livestock unit; counting with normative wages)

The program was run separately for the four objective functions.

\section{EVALUATION OF THE RESULTS}

\section{FROM THE RESULTS OF THE FINAL FUNCTIONS, I SHALL RELATE $C_{\text {I }}$ (MAXIMIZATION OF NET INCOME) AS FOLLOWS}

Farming is approached from the "enterpreneurial viewpoint" of the objective function; farm decisions aim at the maximum enterprise income. From the practical point of view, the objective function shows the following deficiency: owing to the distorted price system, some coefficients of the objective function are negative, that is, also the branches showing a deficit must be located which are unreal economically (but exist in practice).

The optimal location solution would increase to 14.5 thousand million Forints, namely by 80 per cent, the 8.2 thousand million Forints of net income realized in the twelve investigated branches of production of cooperative sector in 1969. This is attained by the programme in such a manner that the free capacities remaining after provision of the minimally compulsory production (1969) for the most profitable branches are used. From the branches of crop production, maize and potatoes $(2 \cdot 5-2 \cdot 5$-fold) and sunflowers (two-fold) increased in area the most significantly; within stockbreeding, the keeping of poultry increased most (the stock is one and a half times as big as it was). Sugar beet and tobacco do not exceed the prescribed minimum in area. The optimal programme shows four branches of production in each county on an average. With crop production, the most important is the growing of maize (nearly 2 million cad. yoke) whose production is concentrated in six counties (the leading county of Békés alone occupies 30 per cent of the country's sowing area).

The eighty per cent increase in income does not make use of all resources available. Some 3.5 per cent is saved from the land basis, 5 per cent from the annual labour supply, and 40 per cent from the machine capacities (strong specialization improve the utilization of machines). 


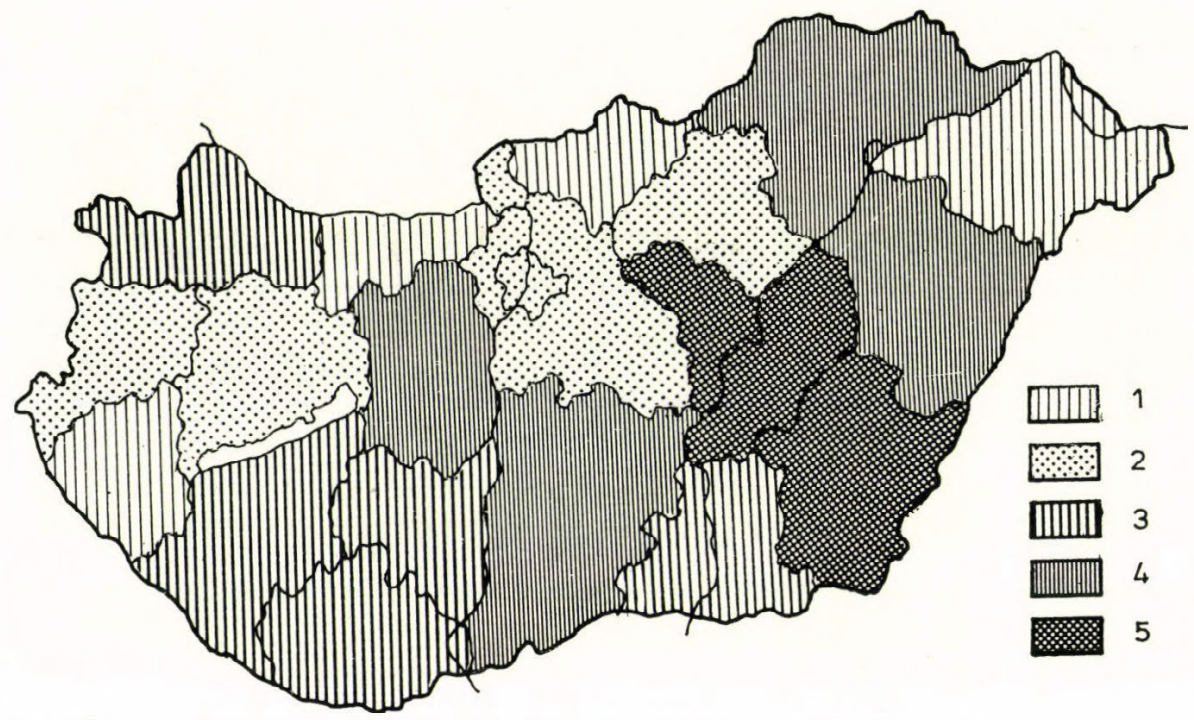

Fig. 1. Cultivation area of wheat. Effective distribution in 1969 (in per cent) $1=1 \cdot 7-3 ; 2=3-5 ; 3=5-6 ; 4=6-8 ; 5=8-10 \cdot 2$

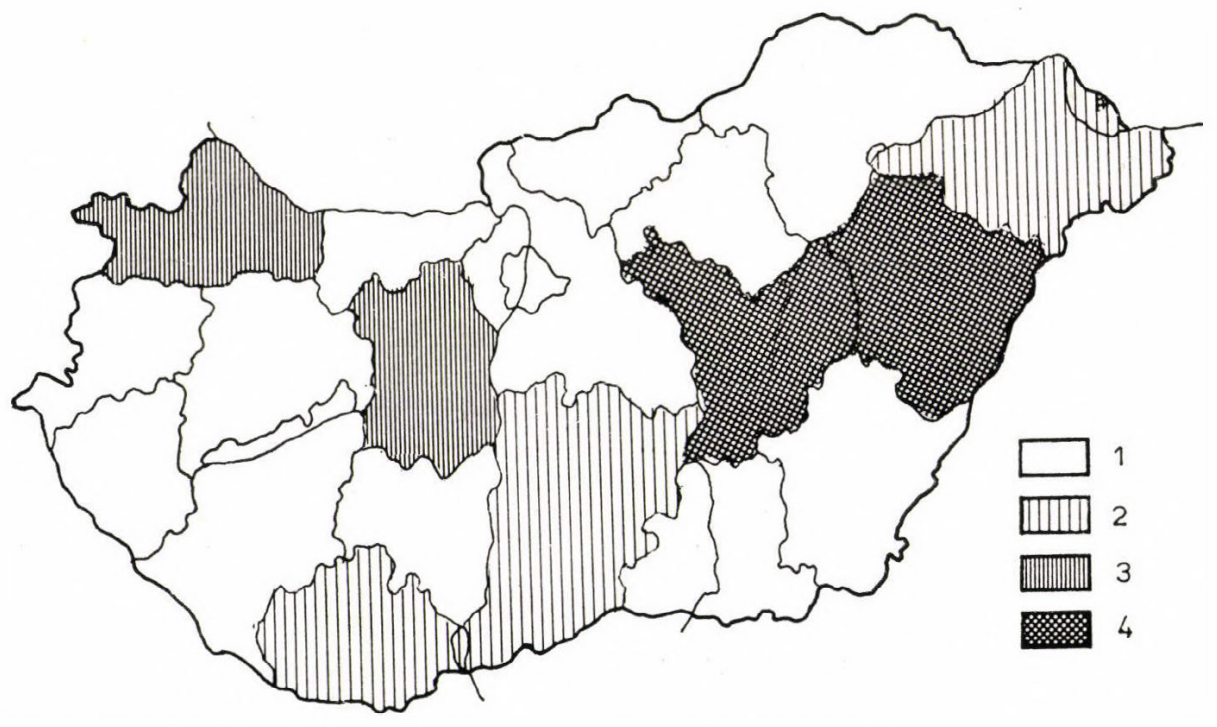

Fig. 2. Optimal distribution according to programme $C_{I}$ (in per cent) $1=0 ; 2=1 \cdot 0-3 \cdot 2 ; 3=13 \cdot 1-19 \cdot 6 ; 4=29 \cdot 0-32 \cdot 6$ 


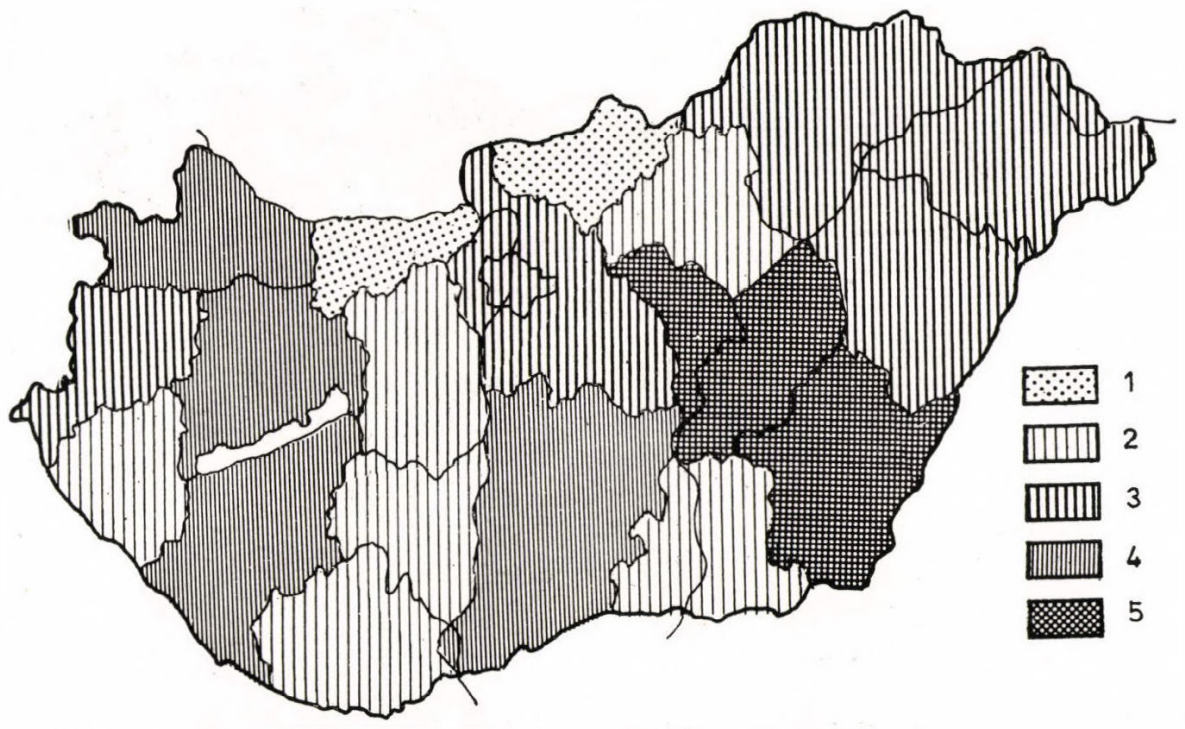

Fig. 3. Cattle-breeding. Effective distribution in 1969 (in per cent)

$1=2 \cdot 4-4 ; 2=4-5 ; 3=5-6 ; 4=6-7 ; 5=7-7 \cdot 1$

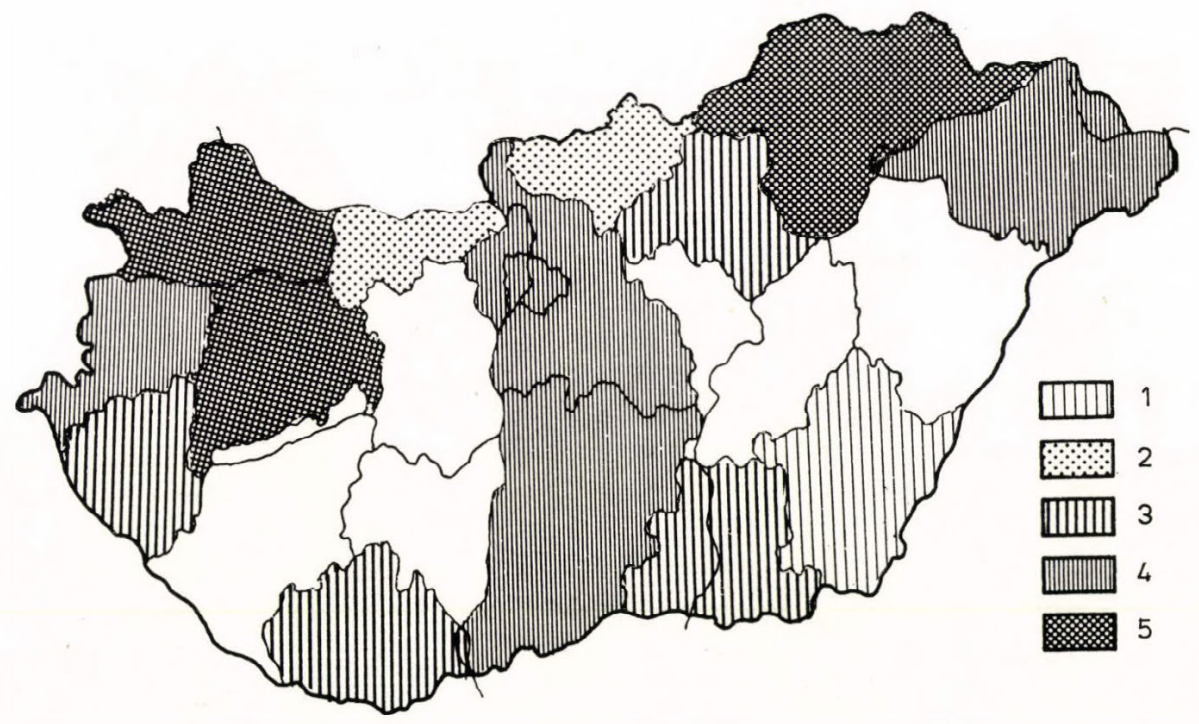

Fig. 4. Optimal distribution (in per cent)

$1=<22=2-5 ; 3=5-8 ; 4=8-9 ; 5=9-10$ 


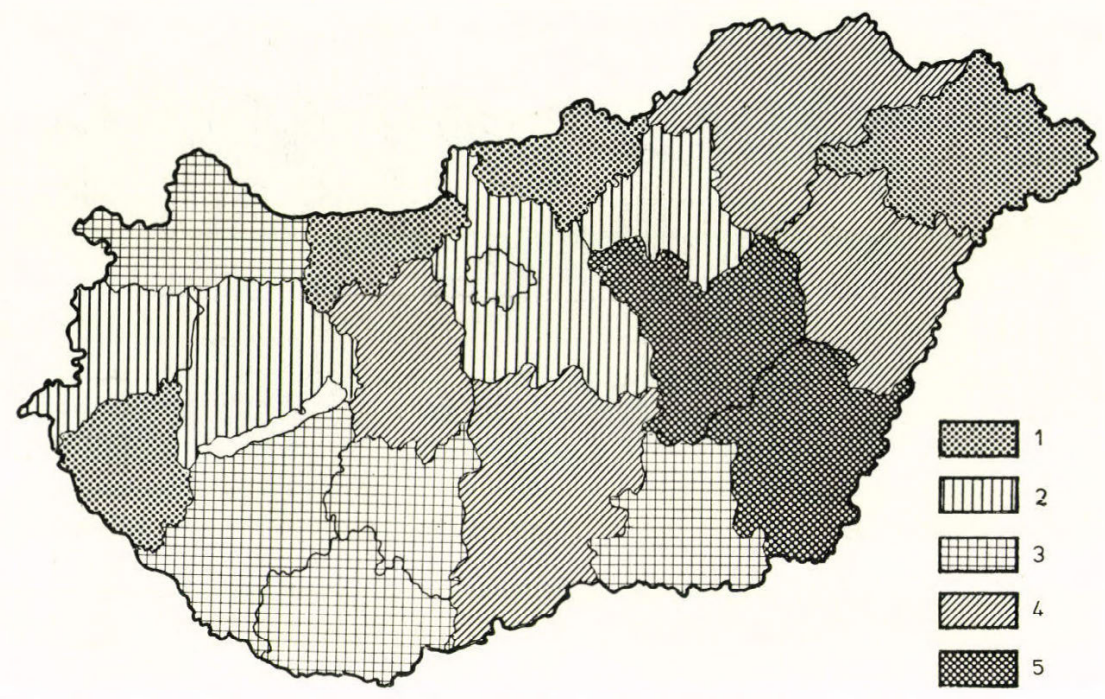

Fig. 5. Sown area of wheat. Effective distribution in 1969 (in per cent) $1=1 \cdot 7-2 \cdot 0 ; 2=3 \cdot 0-4 \cdot 9 ; 3=5 \cdot 0-5 \cdot 0 ; 4=6 \cdot 0-7 \cdot 9 ; 5=8 \cdot 0-10 \cdot 2$

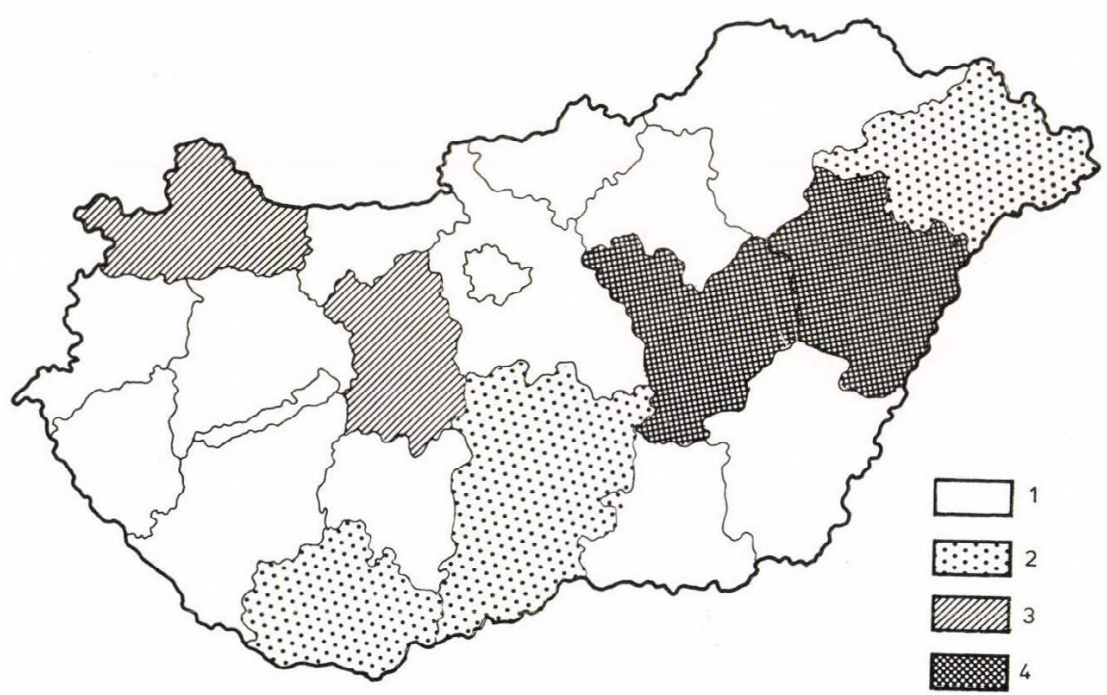

Fig. 6. Optimal distribution according to program $C_{\mathrm{I}}$ (in per cent)

$1=0 ; 2=1 \cdot 0-3 \cdot 2 ; 3=13 \cdot 1-19 \cdot 6 ; 4=29 \cdot 0-32 \cdot 6$ 


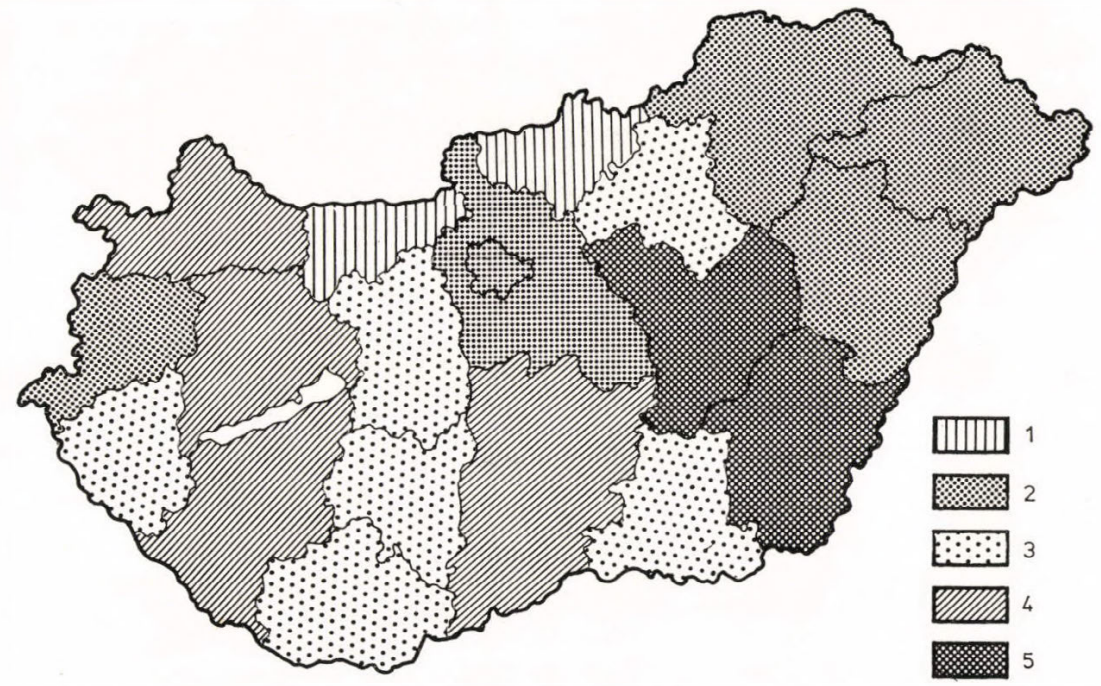

Fig. 7. Cattle-breeding. Effective distribution in 1969 (in per cent)

$1=2 \cdot 4-3 \cdot 9 ; 2=4 \cdot 0-4 \cdot 9 ; 3=5 \cdot 0-5 \cdot 9 ; 4=6 \cdot 0-6 \cdot 0 \quad 5=7 \cdot 0-7 \cdot 1$

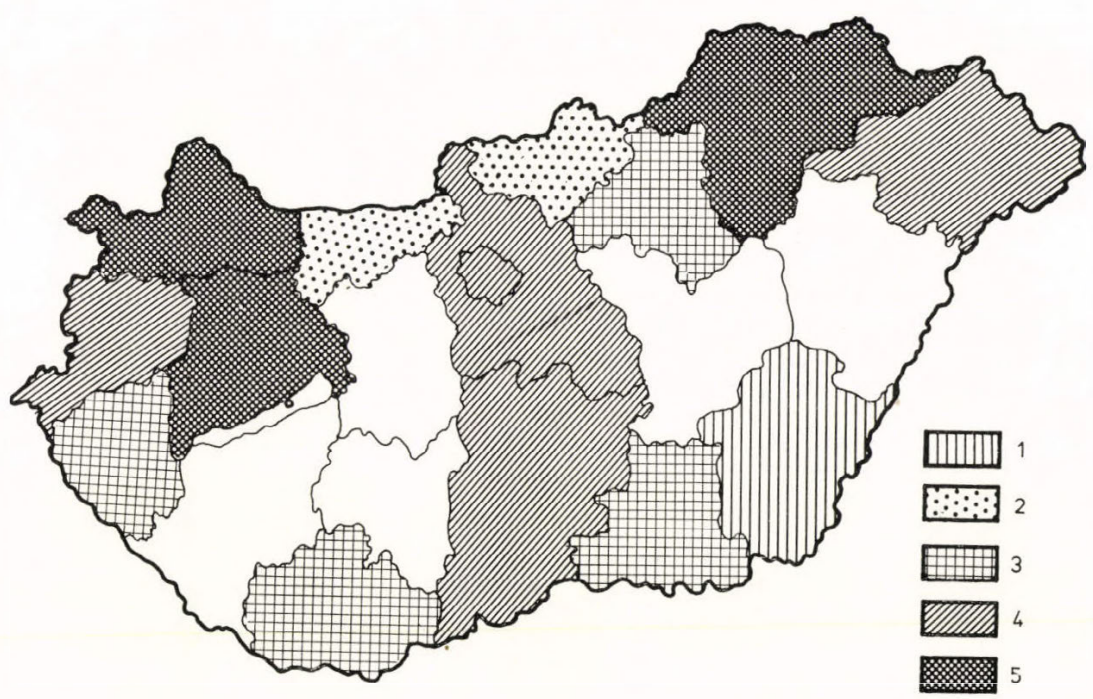

Fig. 8. Optimal distribution (in per cent)

$1=\langle 1 \cdot 9 ; 2=2 \cdot 0-4 \cdot 9 ; 3=5 \cdot 0-7 \cdot 9 ; 4=8 \cdot 0-8 \cdot 9 ; 5=9 \cdot 0-10 \cdot 0$ 



\section{LIST OF CONTRIBUTORS}

BARTA, Gy. $\quad$-research fellow, Research Institute of Geography, Hungarian Academy of Sciences, Budapest, Hungary

BELUSZKY, P. - research fellow, Research Institute of Geography, Hungarian Academy of Sciences, Budapest, Hungary

BERNÁT, T. — professor, Karl Marx University of Economics, Budapest

BORAI, A. - research fellow, Research Institute of Geography, Hungarian Academy of Sciences, Budapest

DeARE, D. $\quad$ - research fellow, University of Texas, Austin

DEMKO, G. J. - professor, Ohio State University, Columbus, Ohio

DESKINS, D. R., Jr. - professor, University of Michigan, Ann Arbor

ENYEDI, GY. - - head of department, Research Institute of Geography, Hungarian

- Academy of Sciences, Budapest

FODOR, L. - - - head of department, Hungarian National Bank, Budapest

HARNER, D. - - research fellow, University of Texas, Austin

HAYNES, K. E. - assoc. professor, University of Texas, Austin

KATONA, S. - - research fellow, Research Institute of,Geography, Hungarian Academy of Sciences, Budapest !

KISH, G. $\quad$ - professor, University of Michigan, Ann Arbor

LOWRY, W. P. - - professor, University of Illinois, Urbana

MORRILL, R. L. - professor, University of Washington, Seattle

PAPP, A. - - assoc. professor, Kossuth Lajos University, Debrecen

PÉCSI, M. - - director, Research Institute of Geography, Hungarian Academy of Sciences, Budapest

PROBÁLD, F. -assoc. professor, Eötvös Loránd University, Budapest

REYNOLDS, D. R. - professor, University of Iowa

SÁRFALVI, B. - - professor, Eötvös Loránd University, Budapest

TATAI, Z. - - professor, School of Political Sciences, Budapest

VANCE, J. E. Jr. - professor, University of California, Berkeley

WHEELER, J. $0 . \quad$ - professor, University of Georgia, Athens 
Other volumes in

STUDIES IN GEOGRAPHY

IN HUNGARY

Vol. 5: Research Problems in Hungarian Applied Geography

Edited by B. SÁrfalvi

Vol. 6: Geomorphological Regions in Hungary

Edited by M. PécsI

Vol. 7: Recent Population Movements in the East European Countries

Edited by B. Sárfalvi

Vol. 8: Problems of Relief Planation

Edited by M. PÉcsI

Vol. 9: The Changing Face of the Great Hungarian Plain

Edited by B. Sárfalvi

Vol. 10: Budapest. An IndustrialGeographical Approach

Edited by I. Bencze and V. E. TAJTI

Vol. 11: Man and Environment

Edited by M. PŕcsI and

F. Probáld

Vol. 12: Regional Development and Planning. British and Hungarian Case Studies

Edited by P. A. Compton and M. PÉCSI

Vol. 13: Rural Transformation in Hungary

Edited by Gy. Enyedi

Distributors

KULTURA

H-1378 Budapest, P. O. B. 149 


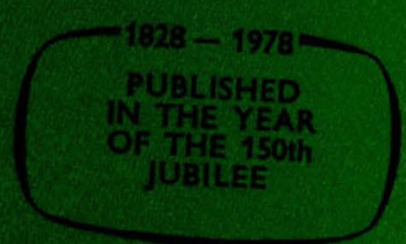

ISBN 9630515148 